\title{
CRIANÇAS E ADOLESCENTES EM SITUAÇÃO DE RISCO PESSOAL E SOCIAL: QUE PROBLEMA É ESSE?
}

\author{
UMAIA EL-KHATIB
}

Tese de Doutorado apresentada ao Departamento de Saúde MaternoInfantil da Faculdade de Saúde Pública da Universidade de São Paulo para obtenção do Grau de Doutor.

Área de Concentração:

Saúde Materno-Infantil

Orientadora:

Profa. Associada Ana Cristina

D'Andretta Tanaka

São Paulo

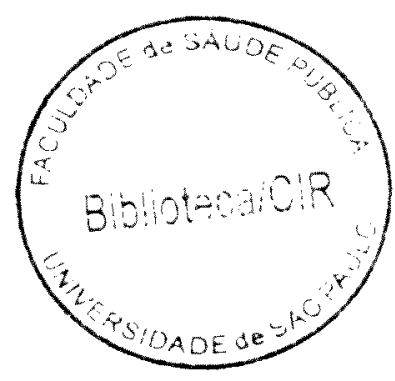

2001 
Agradeço a Deus... ...pela luz, pelo discernimento e pela dor que me permitiu compreender a dor do outro...

....̀̀s crianças e adolescentes... ...que emprestaram da sua história para a minha compreensão... ... acerca delas e de mim mesma..

...aos meus pais... ..meus dois amores... Hafiza e Mustapha Mohamed El-Khatib ...que me ensinaram... ... a amar as pessoas e a acreditar nelas... ... a lutar contra as condiçöes desiguais que separam as pessoas e as impedem de ser respeitadas umas tanto quanto as outras...

...e que, dando de si mesmos para que eu também pudesse crescer, me ensinaram que não é possível ser feliz enquanto alguém sofre, seja dor, discriminação ou desvantagem na vida.. ...que é necessário a cada um de nós dar de si para que o outro também possa ser... 
Este é um trabalho construído a muitas mãos. Por isso considero coletiva a sua autoria.

Profa. Ana Cristina D'Andretta Tanaka... ...foi quem apostou em mim. Minha orientadora nota mil. Porto seguro, ali me aguardando, no tempo meu de aprender... ...sem nunca tolher minha liberdade de criação ou meus vôos, ou meu tempo de chegar onde era desejo chegar... ...contribuindo generosa e às vezes silenciosamente para que meu espírito pudesse se melhorar. Devo-lhe acima de tudo a sustentação e o respeito, que me permitiram encontrar meus próprios caminhos.

Silvana Cristine de Oliveira Bragatto... ... que fez a trajetória toda comigo. Estudando comigo, aprendendo e me ensinando que mesmo pouco a pouco é possível caminhar quanto se tem com quem contar, incondicionalmente... ...que o respeito mútuo é possível, mesmo quando divergimos em nossas opiniōes, se o desejo do bem do outro existe em cada um.

Neusa Pratavieira e Nancy Helena B. Dornfeld... ...que deram do seu tempo e da sua experiência para que eu pudesse entender os registros e compreender o que transcende o papel. Devo-lhes também todo o esforço da disponibilização de cada um dos mais de 2000 processos que pedi para estudar, sem os quais este trabalho não teria sido realizado.

Entre muitos que participaram desta construção estão...

... a Secretaria Municipal da Criança (de Curitiba) que disponibilizou todos os planos e projetos de atenção à criança e ao adolescente, incluindo o espaço para conhecer de perto o seu funcionamento, assim como a discussão crítica acerca de suas dificuldades...

...o Conselho Municipal de Direitos da Criança e do Adolescente de São Carlos e o Conselho Tutelar...

...Dr. Scanavez, prof. Jorge Oishi, meu amigo Dr. Braga...

...Valdo Vieira, Josefa Roiz Cardoso, Jane D'Arc Brito Lessa, Helena Bragatto...

... Walcynir Bragatto, Wladimir Gomes, Edson Luiz Rodriguez Cruz..

...Sueli Maunsell, Sérgio de Oliveira Netto, Dulce Mazziero Piccoli...

... Iara Ap. Macedo e a Materno-Infantil inteira..

...Antonio Carlos Riani Costa, Sebastião Jorge Chamme...

...os alunos dos cursos de direitos e da criança e adolescente em situação de risco pessoal e social... .. enfim, são muitos e não é possível enumerar a todos

... acima de tudo, contudo, devo àqueles que estiveram lado a lado com meu espírito durante toda essa trajetória, mostrando que afinal pertencemos todos uns aos outros... ... minha Familia... ...e meus Meninos... ...os da Liberdade Assistida, os do Núcleo Paz Amor e Fraternidade, os "patrulheiros", os "guardadores de carro", os que estão pelas ruas e os que não puderam adolescer. 


\section{RESUMO}

Esse estudo interessa especialmente aos campos da atividade humana voltados ao tratamento das questões pertinentes à infância e adolescência, cuja natureza, enquanto área de conhecimento é multidisciplinar. Para realizá-lo, partimos da nossa realidade local, o Município de São Carlos. E voltamos nosso olhar para os nossos meninos. É como gostamos de chamá-los. Nossos meninos. Tendo por referência a situação de risco pessoal e social, em que se encontram muitos dos nossos meninos, sejam crianças ou adolescentes, desse município, elegemos por objetivo, conhecer os que passaram pelas mãos do Poder Judiciário da Comarca de São Carlos, caracterizando-os, levantando seu contingente, identificando a natureza das situações por que são atendidos. A partir dessa caracterização, tomar daquelas, as situações "de conflito com a lei", buscando identificar sua natureza infracional, pretendendo conhecer inclusive parte das ações e concepções dos agentes de intervenção, envolvidos nessas situações, relativamente a esses meninos, a quem se imputa a prática de ato infracional, os que tantos de nós insistem tratar-se de "menores" e "infratores".

Essa caracterização é feita inicialmente, a partir dos dados registrados nos Livros de Feitos, no Cartório, da Vara da Infância e da Juventude da Comarca de São Carlos, para uma série histórica de 13 anos, 1984-1996. O estudo mais detalhado acerca da natureza dessas situações é feito a partir dos respectivos processos de três anos dessa série, 1986, 1991 e 1996, o que nos fornece possibilidade de comparação de pelo menos 2 períodos, um anterior ao ECA (1986-1991) em que a referência é o Código de Menores, outro posterior (1991-1996) em que a referência passa a ser o ECA. A comparação vai em busca de possíveis mudanças nas ações e percepções desses agentes. Sendo essa a primeira sistematização acadêmica desses dados, optamos pelo universo de casos, de crianças e adolescentes, atendidos em cada um dos anos estudados, dado nosso interesse em disponibilizá-los posteriormente, para futuras pesquisas. $O$ estudo descreve, portanto, retrospectivamente, a passagem de meninos/as pela Vara da Infância e da Juventude da Comarca de São Carlos, nos 13 anos, do período de 1984 a 1996.

Os resultados encontrados mostram que passam pela Vara, casos de todas as idades, desde os com menos de 1 aos com 17 anos, até alguns com 18 e mais anos de idade; são também de ambos os sexos e a maioria expressiva é residente em São Carlos. Ocorre, nessa 
população, uma aparente concentração de meninos, bem mais numerosos que as meninas, além de uma preponderância dos casos com idade entre 12 e 17 anos. A natureza das situações, pelas quais são atendidos, previamente tomadas por infracionais e não infracionais, foram caracterizadas como infracionais, protetivas, administrativas, precatórias e mal-definidas. Os casos de natureza dita infracional, respondem pelos contingentes mais expressivos dessa população, seguidos pelos dos protetivos, das precatórias, das administrativas e finalmente das mal-definidas. A maioria expressiva dessas situações, envolve apenas 1 criança ou adolescente; os casos envolvendo 2 ou 3 e mais crianças ou adolescentes são bem menos numerosos. A distribuição dessas situações, segundo o mês do seu registro, no respectivo Cartório da Infância e da Juventude, não mostra nenhuma tendência de aumento, em nenhum mês em especial. Relativamente à natureza das situações ditas infracionais, encontramos vários tipos, sendo os mais expressivos, os caracterizados como relativos à furto, relativos à direção de veículo sem habilitação e relativos à agressão. Identificamos, ainda, as medidas adotadas nessas situações, sendo a advertência, a remissão e o arquivamento as utilizadas com mais frequência. Concluímos, não haver diferenças essenciais, na comparação dos dados relativos ao períodos indicados (1986-1991 e 1991-1996); conforme supúnhamos, as concep̧̧ões vigentes à época do Código de Menores, se mantém mesmo com a sua revogação e a aprovação do ECA, o que equivale dizer, que embora a concepção relativa à natureza do problema tenha se modificado, essas crianças e adolescentes continuam a ser responsabilizadas pela própria condição, e tratadas como "problema" de "segurança pública" ou polícia, ou de assistência social. 


\section{SUMMARY}

This study is of special interest to the areas of human activity related to the treatment of questions pertinent to infancy and adolescence, which in nature, is multidisciplinar.

To accomplish this study, we start from our local reality, the city of São Carlos, directing our eyes to "our kids"; this is how I like to call them. Having as a reference, the situation of personal and social risk in which many of "our kids" find themselves, being children or adolescent, we elect as an objective, know the ones that have gone through the hands of the Judicial Power of the District of São Carlos. Firstly, we characterize them, bringing up their contingent, identifying the nature of the situation by which they are attended. After having been characterized, take from them the situations "of conflict with the law " seeking to identify it's infractional nature, also attempting to find some of the acts and concepts of the agents of the interventions involved in these situations, specially related to these kids who have been attributed the infractional practice .... of whom many of us insist in treating as "minors" and "juvenile delinquents".

This description is done inicially from the registered data in the Books of Deeds, in the Infantry and Juvenile Chartulary's Office of the District of São Carlos, to a historical series of 13 years, 1984-1996. A more detailed study about the nature of these situations is achieved from the related processes of three of these years, 1986, 1991 and 1996. This gives us the possibilty of comparison of at least 2 periods, one when the Código de Menores (Minor Code) was valid (1986-1991) and another, when the ECA (Estatuto da Criança e do Adolescente) was held to be valid (1991-1996). The comparison seeks possible changes in acts and perceptions of these agents. Being this the first academic systematizing of these data we chose the universe of cases of children and adolescents attended in each of the years studied because of our interest in having them available for future researches. This study describes retrospectively the passage of boys and girls through the Infantry and Juvenile Chartulary's Office of the District of São Carlos, from 1984 to 1996.

The results show that cases, gone through jurisdiction, are of all ages since under 1 to 17, some even 18 and above; are also of both sex and the expressive majority_living in São Carlos. In this population occurs an apparent concentration of boys, much more numerous than girls, and a preponderancy of cases between 12 and 17 years of age. The 
nature of the situations, by which they are attended, previously taken as infractional and non infractional, were characterized as infractional, protective, administrative, precatory and badly defined. The cases said to be infractional respond to more expressive contingents of this population, followed by the protective, the precatory, the administrative, and finally the badly defined.

More than the majority of these situations involve only one child or adolescent; the cases involving 2 or 3 and more children or adolescentes are less numerous. The distribution of these cases, according to the month of registration, in the respective Infantry and Juvenile Chartulary's Office, does not show a tendency of growth in a special month. Concerning the nature of the situation, said to be of infractional, we find many types, being the more significant, the characterized as related to larceny, to driving vehicles without habilitation, and aggression. We still have identified the measures used in these situations being the admonition, the remission and the filing as used with more frequency. We have concluded that there are no essential differences in comparing the data relative to the indicated periods (1986-1991) and (1991-1996); as we had supposed the valid concepts to the time of the Minor Code, still remain despite the registration and approbation of ECA, which is the same to say that although the concept related to the nature of the problem have been modified, these children and adolescents continue to be considered responsible for their undergoing condition and treated as "a problem" of public security or police or social assistance. 


\section{ÍNDICE}

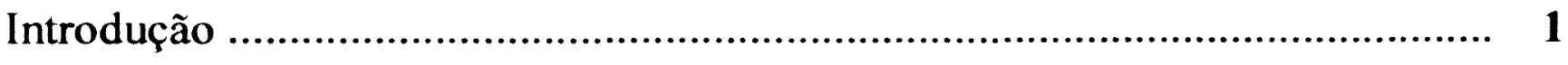

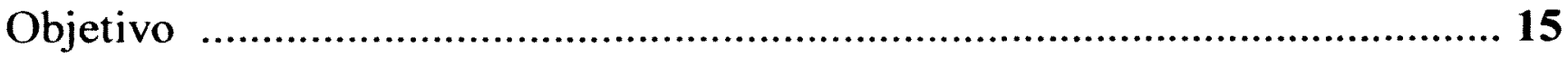

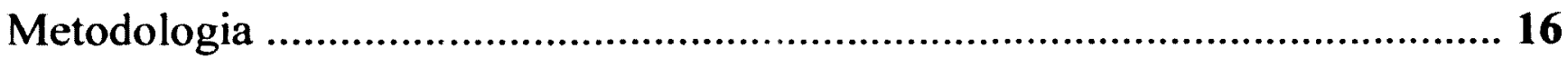

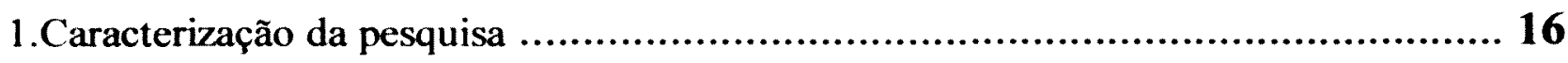

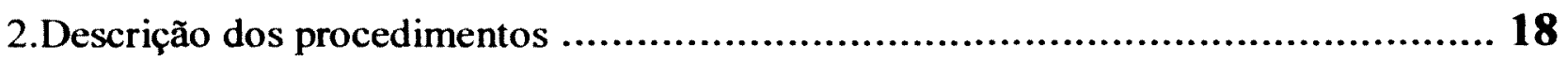

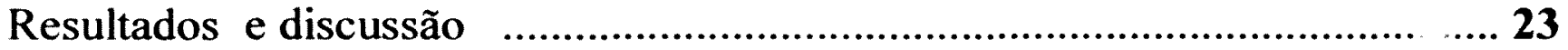

1. Processos/situações registradas no Cartório da Infầncia e da Juventude de São Carlos, da $2^{*}$ Vara Criminal e da Infầncia e Juventude da Comarca de São Carlos e respectivos números de casos atendidos .................................................................................... 23

2. Características das crianças e adolescentes atendidos pela $2^{\text {a }}$ Vara Criminal e da Infầncia e Juventude da Comarca de São Carlos ........................................... 26

3. Natureza das situações/processos que envolvem as crianças e adolescentes atendidos pela $2^{\text {a. }}$ Vara Criminal e da Infância e Juventude da Comarca de São Carlos

3.1. Os processos ou situações não infracionais, protetivos

3.2. Os processos ou situações infracionais

3.3. Outros tipos de situação ou processo: Administrativos, Mal-definidos e Precatórias

4. Magnitude das categorias de situações/processos que envolvem as crianças e adolescentes atendidos pela $2^{\mathrm{a}}$ Vara Criminal e da Infầncia e Juventude da Comarca de São Carlos

5. Magnitude das situações de natureza infracional e das medidas respectivamente aplicadas nessas situações, pelo Juizo da Infầncia e da Juventude da Comarca de São Carlos 58

5.1. Acerca das medidas 58

5.2. Acerca das frequências das situações consideradas infracionais nos anos de 1986, 1991 e 1996 64

Considerações Finais

Referências

Bibliografia Complementar 


\section{LISTA DE TABELAS E QUADROS}

Tabela 1. Série histórica: 1984 a 1996. Número total de processos/situações atendidas pelo Fórum de São Carlos, registradas no Cartório da Infância e da Juventude, distribuídas segundo o ano de referência, o percentual de situaçôes por número de casos atendidos por situação registrada, o número total de casos atendidos e os meses de maior e menor frequência de situações registradas para cada ano. Comarca de São Carlos, SP.

Tabela 2. Número total de casos atendidos pelo Fórum de São Carlos, levantados a partir dos processos/situações registrados no Cartório da Infância e da Juventude, de 1984 a 1996, e sua distribuição por sexo e grupos de idade. Comarca de São Carlos, SP

Tabela 3. Distribuição relativa dos casos atendidos pelo Fórum de São Carlos, registrados no Cartório da Infância e da Juventude, de 1984 a 1996, segundo os grupos etários, para ambos os sexos. Comarca de São Carlos, SP

Tabela 4. Série histórica: 1984 a 1996. Número total de processos/situações atendidas pelo Fórum de São Carlos, registradas no Cartório da Infầncia e da Juventude, e sua distribuição percentual, segundo os grupos de natureza identificados, para cada ano de estudo. Comarca de São Carlos, SP.

Quadro 1. Natureza das situações registradas no Cartório da Infầncia e da Juventude, por categoria e respectivos percentuais, para cada um dos anos estudados: 1984 a 1996. Comarca de São Carlos, SP.

Tabela 5. Distribuição relativa dos casos atendidos pelo Fórum de São Carlos, registrados no Cartório da Infância e da Juventude, de 1984 a 1996, segundo os grupos etários, para as duas principais categorias de situação. Comarca de São Carlos, SP.

Tabela 6. Frequência de casos de crianças e adolescentes, registrados no Cartório da Infância e Juventude, por tipo de situação em que foram atendidos, grupo etário e sexo, nos anos de 1984 a 1996. Comarca de São Carlos, SP

Gráfico 1. Frequência de casos de crianças e adolescentes registrados no Cartório da Infância e da Juventude, por tipo de situação em que foram atendidos, grupo etário e sexo, nos anos de 1984 a 1996. Comarca de São Carlos, SP.

Quadro 2. Medidas de "assistência e proteção" (arts. 14, incisos I a VI e 17, incisos I a V) previstas pelo Código de Menores (BRASIL, 1979) e "medidas específicas de proteção" (art. 101, incisos I a VIII) e "sócio-educativas" (art. 112, incisos I a VII), previstas pelo Estatuto da Criança e do Adolescente, ECA (BRASIL, 1990).

Tabela 7. Natureza e frequência dos casos ditos infracionais registrados no Cartório da Infância e da Juventude de São Carlos, nos anos de 1986, 1991 e 1996. Comarca de São Carlos, SP. 
Tabela 8. Medidas aplicadas pelo Juízo da Infância e da Juventude da Comarca de São Carlos, nas situações ditas infracionais, no ano de 1986 e respectivas frequências

Tabela 9. Medidas aplicadas pelo Juízo da Infância e da Juventude da Comarca de São Carlos, nas situações ditas infracionais, no ano de 1991 e respectivas frequências

Tabela 10. Medidas aplicadas pelo Juízo da Infância e da Juventude da Comarca de São Carlos, nas situações ditas infracionais, no ano de 1996 e respectivas frequências 89

Diagrama do ECA - Estatuto da Criança e do Adolescente 113 


\section{Introdução}

"Crianças e adolescentes em situação de risco pessoal e social" é tema amplo, que abrange uma diversidade de situações. Embora exista farta literatura a respeito, o acesso a essa literatura se dá, mais frequentemente, através de expressões e termos que refletem características da condição de "risco pessoal e social ". Ao que parece, essa expressão é pouco utilizada e mais recente que os termos ou expressões relativos à essa condição, tais como "crianças de rua", "crianças carentes", "criarç̧as abandonadas", "menor de rua", "menor abandonado", "menor", "menor infrator" e outros.

Nessas condição podemos situar não apenas as crianças e adolescentes que estão nas ruas, vítimas da negligência ou abandono, mas todas aquelas que estão sendo vítimas da exploração pelo trabalho, pela prostituição, pelo tráfico de drogas, incluindo as que são usadas para a prática de crimes, bem como aquelas que são vítimas da violência (física, mental, sexual) doméstica ou familiar.

A rigor, se fossemos discutir cada um desses problemas, poderíamos indagar se se constituem "situações de risco pessoal e social" ou de violência efetiva contra a criança e o adolescente.

Não há, a nosso ver, como negar que a violência subjaz como elemento determinante da trajetória perversa e fatal, que muitas crianças e adolescentes percorrem. Uma trajetória que, muitas vezes, começa na violência em casa progride na rua, onde se tornam "mercadoria" "barata" e "descartável" nas mãos de adultos criminosos, que vivem impunemente da exploração da prostituição infantil, do tráfico de drogas e da prática de crimes.

O outro lado dessa violência, ou das situações de risco pessoal e social, é o que coloca a criança e o adolescente na condição de "infrator, delinquente, juvenil, menor em situação irregular" ou ainda, "de conflito com a lei " e que constitui, talvez, a mais complexa das áreas de investigação, que o tema "crianças e adolescentes em situação de risco pessoal e social" abrange.

É, portanto, através desses termos e expressões, ou situações, características da condição de "risco pessoal e social", que se pode constatar que, enquanto tema, esta condição, define na diversidade dessas mesmas situações, uma área de investigação 
complexa, que se desdobra em diversos temas de investigação. Frequentes na literatura, alguns mais outros menos, esses temas conjugam uma série grande de textos, que permitem perceber a abrangência e complexidade do problema.

A análise desse material demonstra a necessidade de estabelecer limites relativamente precisos, para o que se pretende estudar, frustrando parte das pretensões investigativas, na medida em que cada um desses temas apresenta suas próprias especificidades ou diferentes problemas. Dessa forma, cada tema, ou situação pode ser tomado, não isolada mas individualmente como universo singular a ser estudado.

Essa possibilidade foi constatada a partir de um levantamento (publicado) acerca do tema, mostrando a pertinência do estudo dessas especificidades.

Por exemplo, a análise dos textos que tratam da situação "de rua", ou do tema "meninos de rua", "crianças abandonadas", "crianças carentes", "menores abandonados", levanta pelo menos dois problemas. $\mathrm{O}$ primeiro, de natureza conceitual, relativo à ausência de definições e ao uso indiferenciado para os atributos "carente", "de rua", "abandonado". O segundo, talvez decorrente do primeiro, se refere à magnitude do problema, em geral exorbitada e baseada, por sua vez, em cifras superestimadas, cuja metodologia não é identificada. São raros e de dificil operacionalização, os levantamentos para contagem dessa população. ROSEMBERG, $(1993$; 1994) é referência obrigatória para entender esses problemas e sua implicações.

Outra constatação nos parece ser de especial importância, remetendo-nos a outro problema; diz respeito ao fato da identificação da condição ou situação social de "estar na" ou "viver na rua", ser "moleque de rua", "pedinte", "pivete", entre outros, se sobrepor à identificação do papel social, de ser criança ou adolescente. É fundamental consultar GRACIANI $(1992,1996)$ para compreender como e porque isso ocorre. $\grave{A}$ semelhança, diversos estudos tomam crianças e adolescentes por "menores", e essa denominação não é casual. Define a condição marginal e de exclusão em que vivem crianças e adolescentes. Quando o Estatuto da Criança e do Adolescente, (ECA), (BRASIL,1990), "inaugura" a aplicação ou uso, no texto da lei, dos termos "criança e adolescente", reflete entre outros, a proposta de avanço conceitual relativamente ao problema da exclusão dessas crianças e adolescentes. 
A análise de outros textos, projetos e propostas de ação, direcionados para a solução do problema, mostra contudo, que a despeito desse e outros avanços, há distância entre as perspectivas conceituais $\mathrm{e}$ as práticas, voltadas ingenua ou perversamente, para o atendimento da criança e sua família, numa perspectiva redutora, de integrá-las ou recuperá-las, via sua adequação aos parâmetros de comportamento ou conduta "socialmente aceitáveis".

No caso da situação de exploração pelo trabalho, ou do tema "trabalho Infantil", ou "exploração da mão de obra infantil", um dos principais problemas reside na identificação dessa situação, como problema, cuja magnitude vai além do que se tem informado. Discute-se, atualmente, o quanto as cifras divulgadas podem estar aquém do número de crianças efetivamente explorado pelo trabalho.

A nós parece que a maior dificuldade presente no tratamento desse tema reside exatamente aí, na contradição entre números e estimativas, divulgados por uns e a realidade observada e denunciada por outros. Se, de um lado, o limite mínimo de idade para o trabalho é de 14 anos, e nem todo tipo de atividade exercida pela criança ou adolescente é considerada "trabalho" infantil, de outro, sabe-se que há muitas crianças muito pequenas, menores dos 10 anos de idade, de até 5 e 6 anos, quando não menos, exercendo muitas formas de trabalho, não havendo, portanto, coincidência entre as cifras divulgadas e o contingente de crianças e adolescentes efetivamente explorado pelo exercício de qualquer atividade, seja ele remunerado ou não. Ressalta-se ainda que mesmo a categorização de "aprendiz" vem mascarando os dados dessa realidade, legitimando muitas situações concretas de exploração do trabalho infantil. Os dados obtidos a partir dos "Encontros e discussões com Conselhos Tutelares e Municipais de Direitos da Criança e do Adolescente" (ENCONTRO REGIONAL DE CONSELHOS TUTELARES, 1996) e "Seminários sobre a criança em situação de risco" (SEMINÁRIO CRIANÇA E ADOLESCENTE EM SITUAÇÀO DE RISCO, 1996), dão consistência a essas afirmações. A consequência é que não reconhecido o problema em sua magnitude, não é possível enfrentá-lo adequadamente. Pior que isso, servem de justificativa para a não formulação de políticas públicas ou implementação de programas e consequente destinação de recursos para o seu combate. 
Diversamente do que ocorre com o tema "meninos de rua", que é pretensamente tomado como problema afeto a países de "terceiro mundo" _América Latina e Brasil, principalmente, esse é um problema generalizado, atingindo países "desenvolvidos" ou não. A revista Nouvel Observateur, citada por TONIN (1996a), apresenta a alarmante situação mundial, enquanto trabalhos como os de HUZAK e AZEVEDO (1994) e do GRUPO DE TRABALHO NACIONAL (Tribunal Nacional Contra o Trabalho Infantil, 1995) e MATEOS, (1992), colocam-nos frente à gravidade da situação das crianças brasileiras que vivem esse problema, ou a ele sobrevivem.

Outro ponto fundamental de discussão quando se trata da exploração da mão de obra infantil, é a sua representação social. Os textos permitem perceber, que determinantes de natureza econômica, como a redução de custo de mão de obra, são mascarados pela idéia "salvadora" do trabalho ("...é melhor trabalhar, do que ficar na rua..."; "...é melhor trabalhar do que virar bandido..."). É a leitura do preconceito, que coloca a delinquência e o trabalho precoce, ou a "profissionalização", como alternativas únicas de sobrevivência do "adolescente pobre" que "...não pode estudar", "...tem que trabalhar", "...senão vira bandido, delinquente ou marginal".

A proposição de Pactos, como o de Minas (1994), o do Bandeirantes (1996), ou o de Araraquara (1996), reunindo os setores público, empresarial, sindical, acadêmico e outros da sociedade civil, pela erradicação do trabalho infantil, a despeito das concepções ou metodologias propostas, ou das motivações que mobilizam cada setor, sinaliza para um possível avanço, podendo resultar num melhor dimensionamento do problema. Numa perspectiva ainda mais otimista, pode implicar a mobilização de municípios cujos poderes públicos sequer admitem a existência do problema, ou quando admitem, tomam-no por inexpressivo. A necessidade de pesquisas, para o diagnóstico do problema, em termos municipais é evidente.

No que se refere à situação das crianças e adolescentes vítimas da exploração sexual, ou ao tema "prostituição infantil", "prostituição infanto-juvenil" há pelo menos duas referências obrigatórias, DIMENSTEIN, (1995) e DIÁRIO DO CONGRESSO NACIONAL, (1994), para se alcançar a complexidade desse problema, que se coloca a partir da miséria e do mesmo crime organizado, que 
instala o uso de tráfico de drogas entre crianças e adolescentes, não apenas na ruas, mas também nas escolas, atingindo crianças e adolescentes de quaisquer condições sociais, e "adota" crianças e adolescentes para prática de crimes.

É essa uma das principais conclusões que se pode tirar do mais completo documento sobre prostituição infantil, dos que pudemos localizar. Referimo-nos ao "Relatório Final da Comissão Parlamentar de Inquérito Destinada a Apurar Responsabilidades pela Exploração e Prostituição Infanto-Juvenil", (DIÁRIO DO CONGRESSO NACIONAL, 1994), que reúne, além dos referenciais teóricos, quanto à natureza do problema, pesquisa de campo e depoimentos (pelo menos 100) de organizações governamentais e não governamentais, representantes do poder executivo, judiciário e outros, envolvidos ou comprometidos, direta ou indiretamente com o problema, ou com as crianças e adolescentes que vivem essa trágica realidade. A contundência do Relatório na descrição desse quadro é tamanha, que nos fez pensar o quanto a produção acadêmica pode parecer superficial, tímida ou incipiente, diante da magnitude e complexidade do problema.

O mesmo Relatório nos dá conta da realidade brasileira, destacando a situação mais crítica de alguns estados brasileiros; analisa os avanços legais, propondo reformulações e medidas outras, que implicam não apenas a responsabilidade e a mobilização de todos os setores, sociedade civil e Estado, mas a necessidade da concentração de esforços e recursos, para a consecução de políticas públicas e programas de atenção à criança e ao adolescente, não apenas de caráter integral, mas também integrado.

Fica evidente que a prostituição de crianças e adolescentes se mantém não apenas por uma suposta falta de alternativas para combater esse tipo de "organização social", mas principalmente pelo não comprometimento de diferentes setores com ações de enfrentamento do problema.

Outro tema, também colocado como "situação de risco pessoal e social", é a "drogadiç̧ão na infầncia", ou "uso de entorpecente", ou "drogas na adolescência", ou "uso e abuso de drogas por adolescentes". Embora esse seja, provavelmente, entre os temas aqui apresentados, o de maior volume bibliográfico, quando tratado genericamente, em se tratando de sua especificidade relativamente à condição de risco pessoal e social, reduz-se expressivamente a respectiva bibliografia. 
A análise de alguns desses textos mostra que os mesmos diferem quanto à natureza da abordagem, apontando para pelo menos dois modelos diferentes de interpretação. Uma, centrada nos aspectos clínicos e epidemiológicos, voltada principalmente para os efeitos e a prevalência do uso das drogas, de diferentes tipos, na população juvenil ou adolescente. Outra, de caráter mais amplo, voltada principalmente para os determinantes sociais do problema da drogadiç̧ão na infầncia e adolescência. Observa-se, naturalmente, inclusive distinções entre as conceituações utilizadas numa e noutra dessas abordagens.

Foi, contudo, num SEMINÁRIO SOBRE DROGAS, VIOLÊNCIA E EXCLUSÃO(1996), realizado pela Universidade Federal do Paraná, que o tema foi tratado de modo mais abrangente, contemplando-se simultaneamente o caráter clínico e social do problema, colocado pertinentemente como decorrência do processo de adolescer na condição de exclusão e das violências produzidas por essa exclusão em indivíduos que nela crescem e se desenvolvem.

A violência contra crianças e adolescentes, a vitimização infantil, os maustratos, aparecem igualmente no desdobramento dos temas a que nos referimos, quando falamos das "situações de risco pessoal e social".

O primeiro problema no tratamento desse tema está no emprego do termo violência e seus significados, com implicações inclusive sobre a concepção das "situações de risco pessoal e social", aqui tratadas e por nós compreendidas também como situações de violência contra a criança. Desse ponto de vista cada tema ou situação já referida, traduz uma forma diferente da mesma violência.

$\mathrm{Na}$ consulta à respectiva literatura, observa-se também aqui, pelo menos duas tendências diferentes na abordagem do problema. Uma centrada nas consequências biológicas, físicas ou psicológicas da vitimização e voltada principalmente para as intervenções de natureza clínica. Outra centrada nos determinantes de natureza sócioeconômica do problema. Nesse caso, a concepção do problema sinaliza para a necessidade de discussão conceitual do que vem a ser "violência contra a criança e o adolescente" e, consequentemente das formas com que pode se apresentar. Mais além, passa pela necessidade de discussão das "agressões contextuais", como a "privação de cidadania", referidas por BARRETO (1996) e pela discussão dos 
determinantes de natureza político-econômica, referidos por PINHEIRO (1989) e outros.

Outra dificuldade no tratamento desse problema tem especial importância; refere-se ao silêncio em torno dele, a despeito das muitas evidências e mesmo de uma CPI do Extermínio de Crianças e Adolescentes (1991). Na direção oposta, há pelo menos dois autores, SANTOS (1987) e DIMENSTEIN (1990; 1992a; 1992b; 1995; 1995a), cujos trabalhos merecem destaque com relação ao enfrentamento, por vezes contundente, do problema, o que provavelmente decorre da experiência direta desses autores com o mesmo.

É a violência o termo que mais facilmente nos coloca diante de um dos mais dificeis problemas ou temas que as situações de "risco pessoal e social" compreendem. Trata-se, como se costuma dizer, do problema do menor. Isso porque, se de um lado essa expressão é comumente utilizada para se referir também à situação de carência ou pobreza, ou à de rua é, principalmente, à situação de "conflito com a lei", em que se encontram crianças e adolescentes, a quem se imputa a prática de ato infracional, que muitos se referem quando a utilizam. É aqui, que a despeito da identificação de uma condição de "risco pessoal e social" relativamente a essas crianças ou adolescentes, a "caracterização" de condutas ou comportamentos, como infração às normas, e sua "tradução" por "delito", "crime", "infração" ou "ato infracional" coloca essas crianças e adolescentes como sujeitos, autores e atores dessa violência. Tornam-se os "menores", os "infratores" ou os "menores infratores" o alvo, o centro e a resposta para a violência e seu crescimento ou para o "aumento da criminalidade".

A despeito do quão comum possa ser essa leitura, acerca da situação de "conflito com a lei", ou da "imputação de prática infracional" ou de ser considerado não apenas "um", mas também "o" "infrator", a literatura nos permite apontar divergências no tratamento do problema quanto à natureza de seus determinantes. Enquanto em muitos dos textos essas crianças ou adolescentes são reduzidas à condição de sujeitos estruturalmente desviantes e o problema é tomado como jurídico, de polícia ou segurança pública e de assistência social, autores como ALVIM \& VALLADARES (1998) entre outros, que apresentam concepções mais amplas, contemplando elementos de natureza político-econômico-social e cultural, 
na abordagem do problema, nos ajudam a compreender como a categorização dos "menores" "infratores" se constrói historicamente, pelas soluções criadas, para lidar com as contradições decorrentes da adoção de um determinado modelo de desenvolvimento.

Uma comparação entre o CÓDIGO DE MENORES (BRASIL, 1979) e o ECA (BRASIL, 1990), pode demonstrar que essa discussão é não apenas pertinente como fundamental, porque a partir dela se pode justificar a adoção de práticas assistencialistas e reeducativo-punitivas, destinadas à "recuperação" dessas crianças e adolescentes.

Assim, ao contrário do que possa parecer, enquanto objeto de pesquisa, nem o problema, nem sua abordagem numa concepção mais ampla, são novidades.

Todavia, a análise do material permite uma importante constatação. A de que ocorrem mudanças no referencial teórico utilizado. Por exemplo, a incorporação nos textos mais recentes, de termos e conceitos estabelecidos pelo ECA (BRASIL, 1990).

A leitura mais detida de alguns textos nos leva a acreditar que a concepção desse problema se delimita e transforma, a partir da discussão de dois eixos conceituais principais. Um primeiro, anterior ao ECA, que relaciona "marginalidade" e "sistema político-econômico-social" e outro, mais recente, que relaciona "direito" e "sistema político-econômico-social".

Sobrepõe-se dessa forma, pelo menos duas possibilidades de apreensão. Uma, que se debruça sobre a singularidade e as especificidades aqui apontadas para cada uma dessas situações, "de risco pessoal e social". Outra, que se define pelo que é peculiar a todas elas, seu "denominador comum", através do qual podemos articulálas, compreendendo-as como desdobramentos de um mesmo problema. $O$ da exclusão dessas crianças e adolescentes da condição de sujeito de direitos, na medida em que se encontram privadas do acesso a condições mínimas para o seu desenvolvimento, enquanto "pessoa em condição peculiar de desenvolvimento", conforme determina o ECA (BRASIL ,1990).

Excluídos e expostos, transformam-se, inversamente, em "sujeitos" de uma luta injusta pela própria sobrevivência.

O ECA é um marco, que se coloca na perspectiva da superação dessa situação e reflete mudanças conceituais de fundamental importância. Antes dele discutíamos 
a "marginalidade" do "menor". Com o ECA (BRASIL, 1990), ultrapassamos o Código de Menores (BRASIL, 1979) e passamos a discutir o "direito" da "criança e do adolescente". A mudança não é sutil. A criança e o adolescente deixam de estar em "situação irregular", passando essa condição para o Estado, na medida em que esse, sociedade e família, passam a responder pela "proteção integral" de toda criança ou adolescente, de qualquer "ameaça ou violação nos seus direitos fundamentais".

A partir dessa concepção, não mais é admissível considerá-los "o problema". Eles deixam de ser os supostos "culpados" por sua condição. Daí, não mais se justificam soluções para o problema baseadas em ações destinadas exclusivas ou essencialmente para a modificação de suas atitudes e comportamentos.

Se, porém, o ECA (BRASIL, 1990) avança, com a mudança da concepção da situação irregular, para a proteção integral, afirmando os direitos fundamentais de todas as crianças e adolescentes, as condições de pobreza e miséria a que tem sido submetido contigente expressivo de nossas crianças e adolescentes, tem determinado efetivamente sua condição de exclusão, no que se refere ao exercício desses direitos e, portanto, de acesso à sua condição legal de cidadão. O Relatório Final da Comissão Especial de Estudos sobre a Criança e o Adolescente na Cidade de São Paulo (CÂMARA MUNICIPAL DE SÃO PAULO; 1996) e a pesquisa sobre as "Condições de Vida e Pobreza em São Carlos", desenvolvida pelo Departamento de Ciências Sociais da Universidade Federal de São Carlos e divulgada pelo Jornal Folha de São Paulo (São Carlos..., 1997), trazem dados contundentes dessa realidade.

$\mathrm{Na}$ verdade, não encontramos argumento contra sua natureza essencialmente teórica, já que no plano conceitual todas as crianças e adolescentes passam a ter garantidos os seus direitos, mas na vida prática e no cotidiano são inúmeras as excluídas. Uma coisa é, portanto, afirmar o direito, outra é poder exercê-lo.

Assim, talvez devêssemos tomá-lo como uma "carta de intenções", um instrumento de luta por melhores condições de vida para a criança e o adolescente, do que como garantia de direito.

Contudo, o ECA também nos ajuda a acalmar nossa consciências. Reduz tensões coletivas, presentes nas condições de profunda desigualdade social que vivemos, na medida em que, enquanto lei, afirma (nos "dá"), o que a desigualdade social nega (nos "tira"). 
Cabe, pois refletir o que significa igualdade de direitos, numa realidade social desigual como a nossa.

Se pensarmos, por exemplo, especificamente n(os determinantes d)a situação de rua, podemos apontar pelo menos dois fatores reconhecidos como de expulsão de crianças e adolescentes, da familia para as ruas: violência (física: maus- tratos, espancamento, etc; sexual: abuso e estupro ) e miséria.

A violência familiar ou a "fome" de bens materiais mínimos ou outros não acessiveis, mas socialmente valorizados, empurram a criança para fora de casa e na rua o ciclo se perpetua, por outras formas de violência. Ali, droga e prostituição são, geralmente, meios e não fins em si mesmo. Muitas dessas crianças e adolescentes sobrevivem à custa disso. Prostituição e drogas, muitas vezes andam associados, como forma de suportar a própria falta de perspectiva de mudança naquela realidade. Assim como a prática de crimes, principalmente os pequenos furtos, que quando não se prende à possibilidade de aquisição de pequenos bens materiais, pode estar associada à possibilidade de acesso a algum tipo de droga, do qual se tornou dependente e, numa escala de maior perversidade, pode significar a própria possibilidade de continuar sobrevivendo nas ruas.

A miséria é também a principal responsável pela colocação de expressivo contingente de crianças e adolescentes na condição de vítimas da exploração pelo trabalho. A miséria, não apenas econômica, mas também cultural, que nos imprime no ideário uma aceitação natural do trabalho infantil como salvaguarda do risco de um futuro delinquente, marginal e vagabundo.

Para nós, as razões fundamentais dessas situações todas em que se encontram tantas crianças e adolescentes, são econômicas. Qual argumento seria suficientemente consistente para se contrapor aos consideráveis lucros advindos do uso dessa mão de obra tão barata? Justiça social, sem dúvida parece mais que adequado. Assim, nada mais oportuno que a garantia da igualdade de direitos. Cabe, entretanto, indagar, se somos "donos" todos dos mesmos direitos, por que nem todos têm escola.? Por que tantos "moram" em 5,6 quando em 9, 10 ou até mais pessoas, num único cômodo, quando não embaixo de viadutos, ou mesmo amontoados em barracos insalubres? Por que tantas famílias sobrevivem com um salário mínimo por 
mês, quando não menos? Por que tantos vagam pelas ruas, pernoitando ao relento, em becos sujos ou construções?

De que saúde e de que qualidade de desenvolvimento humano se pode falar nessa condições?

Se os caminhos para a modificação dessa realidade estão apontados no ECA, entre eles o reordenamento dos serviços, a municipalização, a prioridade da criança e do adolescente no atendimento, a gestão paritária da sociedade civil e poder público, através dos Conselhos de Direitos na elaboração das políticas públicas e controle das ações destinadas à criança e ao adolescente, a criação dos Conselhos Tutelares para zelar pelo cumprimento desses direitos, havemos que lutar muito tempo para percorrê-los.

Dependeremos não apenas da disponibilidade de recursos, mas da nossa capacidade, enquanto sociedade civil organizada, de controlar sua efetiva destinação segundo as prioridades identificadas pelos diagnósticos da situação das crianças e adolescentes do munícipio.

Dependeremos além, do esforço individual e coletivo para construir novos modelos de atenção, definindo novas práticas de intervenção, orientadas não mais para o "problema do menor", mas para a criança e o adolescente cidadãos.

Como se vê são grandes os desafios a serem vencidos.

É nossa intenção, com este estudo, abrir espaço para a reflexão sobre as dificuldades para a construção dessas práticas.

São Carlos é o município escolhido para a realização do estudo, porque não é, como insistem alguns, diferente de outros municípios, onde o problema existe. Aqui também, longe ainda de se constituir clientela de serviços públicos, essas crianças e adolescentes continuam sendo metas abstratas de propostas de Políticas Públicas, que, por diversas dificuldades, não se transformam em programas ou ações.

De um lado, a lei determinando a proteção e a atenção integral e prioritária à criança e ao adolescente, de outro, a realidade política econômica e social determinando a cultura do descaso, da omissão, da conivência e da prática de violências diversas contra a criança e o adolescente.

A investigação e o diagnóstico local colocam-se como condição necessária para que se desencadeie o processo de identificação de alternativas de intervenção, 
consistentemente apoiadas no conhecimento dessa realidade local. Embora se reconheça que a possibilidade de formulação de propostas adequadas a promover alterações nessa realidade, depende, não apenas desse conhecimento, mas também do compromisso do nosso Município, sociedade civil e poder público, com o resgate da cidadania de nossas crianças e adolescentes, sem um diagnóstico local, não há como sair das discussões e propostas genéricas para o problema e iniciar a construção de qualquer solução mais eficaz.

Datam de maio de 1995 as "Prioridades Para Ação" formuladas e apresentadas pelo CONSELHO MUNICIPAL DE DIREITOS DA CRIANÇA E DO ADOlesCente DE SÃo CARlos (1995), ao Poder Público Municipal. O instrumento contempla as políticas sociais básicas, priorizando os direitos à Saúde e Educação; a política de Assistência Social, priorizando os progamas de Abrigo e Apoio Sócio-Familiar e, as políticas de proteção especial, priorizando os programas para "meninos/meninas de rua", "adolescentes com prática de ato infracional" e "drogadictos". A despeito disso, persistem as lacunas nas politicas públicas desse Município, no que se refere ao atendimento integral à criança e ao adolescente. Se a criança foi ou é prioridade do poder público municipal, a realidade reflete a ausência de ações ou programas que dêem consistência a essa afirmação ou crédito ao suposto compromisso.

É necessário reconhecer que, se avançamos com a criação e instalação dos Conselhos, um, o Tutelar, em 1994 (hoje em sua terceira gestão), outro, o Municipal de Direitos da Criança e do Adolescente de São Carlos, em 1991 (atualmente na quinta gestão), as dificuldades que os mesmos enfrentam, desde o início de suas atividades até hoje, na implementação de ações, que garantam os direitos fundamentais das crianças e adolescentes, dão conta das fragilidades do Município, tanto no que se refere à disponibilidade de equipamentos públicos, seja de educação, saúde, cultura ou mesmo de assistência social, como na oferta de programas. Acima de tudo, essa fragilidade nos remete para o que entendemos ser a maior de todas as dificuldades, qual seja, a de vencer a "diferença" entre o poder que a lei determina e a possibilidade política de exercê-lo. $\mathrm{O}$ acompanhamento sistemático dos trabalhos do nosso Conselho Municipal de Direitos da Criança e do Adolescente, assim como do 
nosso Conselho Tutelar (Relatório do Conselho Tutelar, ano de 1994...), deixa nítida a perversa correlação de forças que caracteriza a realidade local.

Por isso, a despeito c... Prioridades definidas pelo Conselho Municipal de Direitos da Criança e do Adolescente de São Carlos, e dos esforços do Conselho Tutelar de São Carlos para exercer seu papel e cumprir suas funções, conforme determina o ECA, crianças e adolescentes continuam chegando diariamente ao Fórum e ao Conselho Tutelar, ou passando pelas mãos da polícia, porque fora das escolas, perambulam pelas ruas, "ameaçando-nos" com sua desigualdade e suas formas "anti - sociais" de superação dessa desigualdade.

Propostas continuam surgindo baseadas em diagnósticos genéricos dos problemas que afetam essa população. A isso se associam o discurso da intenção e a prática da omissão às vezes até explicada, mas dificilmente justificada, bem como a prática do assistencialismo que, se ameniza, não resolve.

Assim, a busca do diagnóstico local se coloca como necessidade, na medida em que se pretende o seu reconhecimento como problema também de Saúde Pública.

É preciso conhecer a realidade dessas crianças e adolescentes e discutir nossas concepções acerca delas e do seu atendimento, para buscar ações de caráter integral e integrado, que nos permitam superar ações de natureza fragmentada e redutora, já ultrapassadas pelo ECA.

Parece-nos, assim, necessário indagar sobre nossas concepções. Será, que apesar do reconhecimento público de sua condição de criança e adolescente, de pessoas em condição peculiar de desenvolvimento e sujeitos de direitos e, do reconhecimento das condições de desigualdade em que vivem, essas crianças e adolescentes não continuam a ser vistas e tratadas, nesse Município, como problema jurídico, de policia e segurança pública ,ou apenas de assistência social?

A tentativa de buscar resposta, para essa indagação, vem do desejo profundo de encontrar parceiros para refletir sobre nossas possibilidades de transformação dessa realidade.

Temos razões fundadas na prática e na observação, que nos fazem crer que, a despeito do ECA, persistimos sustentando a contradição no exercício de nossas ações. Um discurso bem intencionado, claro, profundo e abrangente, quando tratamos do problema e seus determinantes, mas redução e segmentação, quando 
tratamos das ações ou das propostas de intervenção e solução para o problema. Significa dizer que, embora tenhamos superado a "idéia-tese" de que a criança e o adolescente são responsáveis pela situação em que estão, ou autores exclusivos de sua própria história, e tenhamos aprendido a pensar neles como pessoas em desvantagem, que não tiveram as mesmas oportunidades que nós, no cotidiano das ações, continuamos "viciados" em "ajudá-los" e em "assistí-los em suas necessidades materiais e morais". Continuamos "dando comida , cesta básica, bolsa educação, passe de ônibus, etc. etc. etc.", ensinando religião, higiene, "obrigando" ‘a matrícula em escola, oferecendo "cursos profissionalizantes", ensinando o "certo" e o "errado", disciplinando-os, e punindo-os quando "não conseguem aprender".

Quer finalmente dizer que aprendemos a reconhecer sua igualdade de direitos, ou os "seus direitos", mas não sua igualdade, enquanto pessoa, ou a "sua pessoa".

Pretendemos, com este estudo, levar os problemas das crianças e adolescentes "em situação de risco pessoal e social", para serem refletidos no âmbito da Saúde Pública, mais especificamente da Saúde Materno-Infantil.

É nossa intenção, ao realizar a sistematização de dados históricos, registrados no Cartório da Infầncia e da Juventude do Fórum dessa Comarca, disponibilizar uma série histórica de 13 anos (1984-1996) para futuras consultas e pesquisas pela comunidade.

Entendemos que o trabalho não haverá de mostrar a realidade, mas estamos certos de que constitui um passo importante no longo caminho das sucessivas aproximações, que representam cada esforço de pesquisa, para compreendê-la. 


\section{Objetivos}

Tendo por referência a situação de risco pessoal e social, em que se encontram muitas crianças e adolescentes, desse município, elegemos por objetivo, conhecer aquelas que passaram pelas mãos do Poder Judiciário da Comarca de São Carlos e por ele foram atendidas.

Pretendemos a sua caracterização, dando a conhecer quantas são elas e qual o seu perfil, assim como, qual a natureza das situações pelas quais são atendidas.

A partir dessa caracterização, tomar daquelas, as situações de conflito com a lei, as ditas infracionais, buscando identificar sua natureza infracional.

Finalmente, identificar ações e concepções de agentes de intervenção envolvidos nessas situações. 


\section{Metodologia}

\section{.Caracterização da pesquisa}

Este estudo interessa especialmente aos campos da atividade humana voltados ao tratamento das questões pertinentes à infância e adolescência. Ou seja, interessa àqueles, cujo exercício do papel profissional envolve crianças e adolescentes: sejam profissionais da saúde, da educação, da segurança pública, sejam operadores do direito, assistentes sociais, psicólogos, sejam, enfim, profissionais ligados à administração pública. Para nós não só o tema, como o problema é de natureza multidisciplinar.

$\mathrm{O}$ objeto de estudo deste trabalho, numa primeira etapa, constitui-se dos processos das crianças e adolescentes, que passaram pela Fórum de São Carlos, $2^{\mathrm{a}}$ Vara Criminal e da Infância e da Juventude, no período de 1984 a 1996. Parte-se dessa série histórica para a caracterização geral dessa população.

$\mathrm{Na}$ segunda etapa, tendo em vista o objetivo da caracterização daquelas envolvidas em situações ditas infracionais, nosso objeto de estudo passa a se constituir apenas dos processos ditos infracionais, de 3 anos tomados daquela série histórica de 13 anos, 1986, 1991 e 1996.

Optou-se pela leitura e análise dos processos compreendidos como infracionais, para esses 3 anos, tomando-se por referência, o ano completo mais recente, ao início da pesquisa, ou seja 1996. Dele se pode estabelecer comparações com anos anteriores, respeitando-se o intervalo de 4 anos, procurando-se identificar modificações na expressão do contingente estudado, tendo em vista a ocorrência de alguns eventos, como a instalação do Conselho Municipal de Direitos da Criança e do Adolescente de São Carlos, que ocorre no ano de 1991 e, anteriormente a isso, um dos anos de vigência do Código de Menores, cuja referência, neste estudo, é 1986. Desta forma, temos pelo menos 2 períodos quinquenais, um de 86 a 91 e outro de 91 a 96, que representam pelo menos duas concepções distintas: a primeira, que se refere à concepção de "criança em situação irregular", decorrente da vigência do Código de Menores (BRASIL, 1979) e a segunda, que deve refletir o pressuposto da "proteção integral" da criança e do adolescente, proposta pelo Estatuto da Criança e do Adolescente (BRASIL, 1990). 
Numa e noutra etapa, embora presente a possibilidade da utilização de amostragem, preferimos conhecer o universo de casos, de crianças e adolescentes, atendidos em cada um dos anos estudados, dado nosso interesse em disponibilizar todos os dados, para o próprio Fórum, após sua sistematização.

Diz-se do caso atendido, porque a mesma criança ou adolescente pode estar presente, não só em vários processos no mesmo ano, como em outros, nos demais anos de estudo.

Nossa fonte de dados foi constituida pelos 6 primeiros Livros de Feitos de Cartório da Infância e da Juventude de São Carlos, que são os Livros de Feitos de número 2 a 7 , os quais contêm os registros de passagem de crianças e adolescentes por esse Fórum, nos anos de 1984 a 1996; além deles, incluíram-se, na segunda etapa, todos os processos relativos aos registros de situações de natureza dita infracional, dos anos de 1986, 1991 e 1996, assim como alguns dos demais tipos de natureza e demais anos, tendo em vista a sua descrição.

Nosso estudo é, portanto, retrospectivo, abrangendo 13 anos, correspondentes ao período que vai de 1984 a 1996, bem como descritivo. Busca, na primeira etapa, caracterizar essa população, segundo os dados registrados nesses Livros, incluindo a caracterização dos tipos de situação ali encontrados. Na segunda etapa, busca identificar a natureza das situações ditas infracionais, tomando por base o estudo de três, desses 13 anos. Conclui com a identificação das medidas adotadas nessas situações, tendo em vista a tentativa de conhecer algumas das concepções sobre essas crianças e adolescentes, ali presentes.

Utilizamos como instrumento 4 tipos de fichas diferentes: 2 modelos foram criados para a transcrição dos dados registrados nos Livros de Feitos; um primeiro, contendo os dados selecionados para esse estudo e um segundo modificado, para transcrição dos registros, caso a caso; outro modelo foi criado para o registro de leitura de processo (data, total de horas, número e ano dos processos lidos, total de processos lidos) e finalmente, um modelo de questionário para digitação e tabulação dos dados já codificados (Anexos: Modelos de 1 a 4). Os dados foram introduzidos no banco de dados do aplicativo EPI-Info5.

Quanto aos procedimentos de análise, como uma de nossas preocupações, é a sistematização dos dados encontrados (nos Livros de Feitos e nos processos), na 
perspectiva de uma pesquisa histórica e, tendo em vista, a natureza essencialmente descritiva desse trabalho, optamos por não ir além da estatística descritiva simples no seu tratamento, para o que fizemos uso do referido aplicativo, que nos permitiu chegar às frequências desejadas. Nos utilizamos, também, da categorização por semelhança, mas mesmo na formação dessas categorias, aquela preocupação foi resguardada, com a apresentação dos tipos ou categorias individuais, originalmente encontrados. Dessa forma, a maior parte dos dados é também, de natureza objetiva. De outro lado, contemplando a busca das concepções, lançamos mão das inferências e das deduções, derivadas da leitura e compreensão dos pareceres contidos nos registros desses processos, motivo pelo qual, o trabalho também inclui dados de natureza subjetiva.

Destacamos aqui, que seguimos algumas sugestões apresentadas por ABRAMO (1979), para a análise das características dessa pesquisa.

\section{.Descrição dos procedimentos}

Esse trabalho teve início em fevereiro de 1996, com a discussão da nossa preocupação acerca da situação da infância e adolescência no Município de São Carlos, acompanhada da apresentação da proposta de estudo, ao Juiz da $2^{\text {a. }}$ Vara Criminal, da Infância e Juventude da Comarca de São Carlos, Dr. João Baptista Galhardo Jr.. Considerada a importância e a necessidade de um possivel diagnóstico, baseado nos dados disponiveis no Cartório da Infância e da Juventude, antes não realizado, a receptividade foi total e os Livros de Feitos, assim como os processos, ali registrados, foram disponibilizados para consulta e leitura.

Os procedimentos realizados obedeceram à seguinte sequência:

- consulta aos Livros de Feitos do Cartório da Infầncia e Juventude, da $2^{\circ}$ Vara Criminal, da Infância e da Juventude da Comarca de São Carlos, inicialmente sob a supervisão e orientação da então Diretora do Cartório, Nancy Helena B. Dornfeld e posteriormente monitorada pela Chefe do Arquivo, Neusa Pratavieira, para o levantamento dos feitos, ou processos, registrados nesses livros;

- seleção dos principais dados registrados, para cada ano de registro encontrado; 
- transcrição dos dados selecionados, para uma ficha de registro (Anexo: modelo 1), contendo: número e ano de registro, sexo, idade, tipo de feito ou natureza do processo, data de ajuizamento da ação penal, finalização e fonte; podem assim ser definidos:

- o número de registro corresponde ao número de ordem do registro no livro de Feitos correspondendo o ano de registro, ao ano em curso e igualmente ao ano em que o fato/feito ocorre e é registrado no Cartório;

- o sexo e a idade são parte dos dados que identificam a criança ou adolescente a que se refere aquele número de registro;

- tipo de feito ou natureza do processo refere-se à descrição da situação/fato à que se refere aquele número de registro;

- data de ajuizamento da ação penal refere-se à data de conhecimento (e portanto do próprio registro) da situação/fato, pela Vara/Juizo;

- finalização refere-se ao procedimento final determinado pelo Juiz e cumprido pelo Cartório, para o processo identificado por aquele número de registro;

- a fonte identifica o Livro de Feitos, do Cartório da Infância e da Juventude, onde constam os registros consultados e de onde os mesmos foram transcritos; até então eram 6 os Livros de Feitos desse Cartório, numerados de 2 a 7.

- transcrição dos dados da ficha modelo 1, para a ficha modificada de registro (Anexo: modelo 2), de modo a: primeiro, incluir os dados relativos ao número de crianças/adolescentes identificados por aquele número de registro, bem como a data da finalização e a localização do processo, tendo em vista a necessidade de posterior leitura do mesmo; segundo, excluir os dados relativos à origem, ou procedência dessas crianças/adolescentes, inicialmente coletados, uma vez que, o Cartório da Infầncia e da Juventude esclareceu que os "casos" "de fora", de São Carlos, são encaminhados para a Comarca de origem, ou obedecem procedimentos por precatória; 
- codificação e digitação dos dados dessas fichas;

- tabulação e descrição estatistica simples dos resultados;

- apresentação das informações obtidas a partir da descrição estatística desses dados; essas informações referem-se:

- ao número de processos registrados para cada ano estudado;

- ao número total de crianças/adolescentes envolvidos nesses processos;

- ao número de crianças/adolescentes envolvidos por processo, a partir do qual foi possível conhecer o contingente de processos, que envolviam 1, 2 ou 3 e mais crianças/adolescentes;

- ao número de crianças/adolescentes de cada sexo, envolvidos nesses processos;

- ao número de crianças/adolescentes para cada uma das idades encontradas (menor de 1 a 18 e mais anos de idade), a partir do qual se pode conhecer o contingente de 3 grupos etários de crianças/adolescentes envolvidos nesses processos, definidos de "menor de 1 a 11 anos de idade", "12 a 17 anos de idade" e "18 e mais anos de idade";

- ao número de processos registrados em cada um dos 12 meses do ano estudado;

- ao número de processos de cada natureza encontrada naquele ano de estudo, incluídas aí todas as categorias de natureza encontradas, conforme os registros nos próprios Livros de Feitos.

Uma vez listadas, essas naturezas são descritas, analisadas e agrupadas por semelhança, em categorias maiores. São então quantificadas/medidas, por suas frequências, individuais (categorias encontradas) e grupais (categorias criadas), assim como parciais e totais, relativamente ao universo de estudo e à série histórica estudada. 
A etapa seguinte compreendeu o levantamento e a requisição de todos os processos, identificados como de natureza infracional dos 3 anos escolhidos, para leitura e estudo. À medida que eram disponibilizados, esses processos eram lidos e analisados, registrando-se em seguida as principais conclusões dessa análise. Dessa forma foi possivel a identificação da natureza dos fatos, situações ou atos considerados infracionais, bem como das medidas ou procedimentos adotados em cada uma dessas situações.

Concluídas as leituras desses processos, pudemos apresentar a descrição dos tipos ou categorias de natureza infracional ali encontrados, assim como das medidas adotadas frente a elas, para cada um dos três anos estudados, 1986, 1991 e 1996, incluindo suas frequências de aplicação.

É necessário dizer que tivemos que tomar uma decisão relativamente à definição dos grupos etários, já que a idade de referência, quando se trata da adolescência é bastante relativa, variando entre os autores que estudam o processo de desenvolvimento humano, assim como entre os autores que trabalham com indicadores sociais, tais como inserção no mercado de trabalho. Considerando os objetivos desse trabalho empregamos aqui o que o ECA (BRASIL, 1990) propõe: até 12 anos de idade incompletos considera-se criança, entre 12 e 18 anos de idade, adolescente.

Destacamos que, como os registros dos Livros de Feitos datam de 1984, nossos dados partem desse mesmo ano de estudo. E ainda, que coletam-se os mesmos dados, para os anos de 1984 e seguintes disponíveis, até 1996, repetindo-se, portanto, os mesmos procedimentos metodológicos para cada ano estudado.

É importante que se registre que o volume expressivo de dados demandou, conforme esperado, longo tempo de coleta, mas trouxe também a necessidade de conferir sistematicamente os registros das fichas, com os registros dos Livros de Feitos e com os dados digitados, o que aumentou o tempo inicialmente previsto para a coleta de dados.

Foi necessária a retomada dos procedimentos de coleta de dados, especificamente, de repetidos procedimentos de verificação dos registros, ora nos Livros de Feitos do Cartório, junto ao Fórum, ora nos processos, junto ao Arquivo do Fórum, cotejando-os com nossas fichas de transcrição, não apenas em função de 
corrigir lacunas e incorreções, devidas à falhas de transcrição, mas também por termos deparado com casos de lacunas de registros nos próprios Livros de Feitos; isso trouxe como resultado a necessidade de nova busca de processos no Arquivo, tendo em vista a caracterização desses casos, em que ocorriam lacunas de registro.

Embora a verificação dos dados coletados seja prática necessária em estudos desse tipo, à semelhança de uma análise de consistência, não esperávamos nós, da nossa parte, encontrar problemas nos registros, já que são de natureza oficial. Além disso, essa verificação levou muito mais tempo do que o previsto, não apenas pelc volume de dados, mas porque implicou no retorno ao Fórum, em horários compativeis com a disponibilidade do Cartório, para novas consultas aos Livros de Feitos, assim como na disponibilização de tempo da chefe do Arquivo do Fórum, para levantar além daqueles já solicitados para leitura, outros processos, apenas para consulta e busca de dados que não constavam dos livros.

Finalmente, é importante que se revele que houve necessidade de um tempo muito maior que o previsto para a leitura dos processos, em função do tipo de informação ali encontrado; trata-se de registros que descrevem muitas vezes eventos "pesados", de difícil leitura e trazem informações pessoais que revelam histórias de sofrimento e dificuldade, que nos põe frente a frente com nossos próprios sentimentos, mobilizando-nos a reflexão em torno de nossos próprios valores, acerca do "certo" ou do "errado"; ...longa ...árdua, torna-se então a tarefa de "sair para olhar", buscando a necessária distância que se exige do pesquisador. 


\section{Resultados e discussão.}

\section{Processos/situações registradas no Cartório da Infância e da Juventude de São Carlos, da $2^{\circ}$ Vara Criminal e da Infância e Juventude da Comarca de São Carlos e respectivos números de casos atendidos.}

Foram estudados 6 Livros de Feitos do Cartório da Infância e da Juventude, da Comarca de São Carlos; foram 9.215 situações estudadas, incluindo todos os tipos de situação ali registrados, total esse obtido pela somatória dos totais obtidos para cada um, da série de 13 anos, por nós estudados, 1984 - 1996.

À esse total de situações ou processos, correspondeu o total de 12.454 casos atendidos. Diz-se do 'caso atendido', porque um único processo pode incluir mais de uma criança ou adolescente, como veremos e, porque a mesma criança ou adolescente pode aparecer em mais de um processo, ao longo do mesmo ano, assim como em outros processos de outros anos.

Essas situações, uma vez registradas, são autuadas, recebendo por conseguinte, a denominação de 'autos' ou 'processos', por esse motivo, convencionamos utilizar também o termo 'processo', a despeito de algumas dessas situações não constituírem 'processos' propriamente ditos (não necessariamente formarem autos), caso de algumas situações de natureza administrativa, que veremos mais adiante.

A Tabela 1 apresenta o número total de processos/situações registradas, assim como o número total de casos atendidos, para cada ano estudado, bem como o percentual dessas situações, por número de casos atendidos além dos meses de maior e menor frequência de situações registradas, por ano.'

Quanto ao número de situações/processos registrados, destaca-se que, no ano de 1984, o total de 299 processos, é relativo aos meses de fevereiro a dezembro, já que os registros do

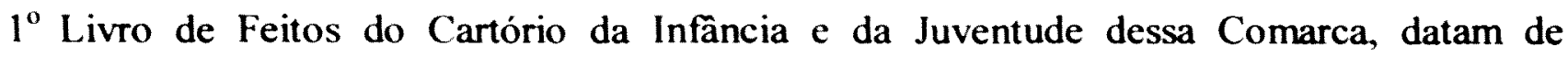
fevereiro e não janeiro, como ocorre para os demais anos estudados. O número total de casos atendidos nesses processos foi de 379 .

\footnotetext{
'Os resultados detalhados, obtidos em cada um dos anos estudados (1984 a 1996) são apresentados individualmente (por ano estudado) nas tabelas numeradas de 1 a 26; anexos de número 5 a 30.
} 
Para os demais anos, 1985 a 1996, veja na Tabela 1, o número total de processos tende a aumentar, totalizando 423 processos em 1985, 512 em 1986 e 535 em 1987; cai para 479 processos em 1988 e volta a aumentar novamente em 1989 e 1990 , totalizando 627 e 738 processos respectivamente. Em 1991 continua aumentando, chegando a 966 processos em 1992. De 1992 para 1993 diminui para 899 processos e volta a aumentar para 988 e 1003 processos respectivamente em 1994 e 1995 . De 1995 para 1996 volta a diminuir para 953 processos.

Tabela 1. Série histórica: 1984 a 1996. Número total de processos/situações atendidas pelo Fórum de São Carlos, registradas no Cartório da Infância e da Juventude, distribuídas segundo o ano de referência, o percentual de situações por número de casos atendidos por situação registrada, o número total de casos atendidos e os meses de maior e menor frequência de situações registradas para cada ano. Comarca de São Carlos, SP.

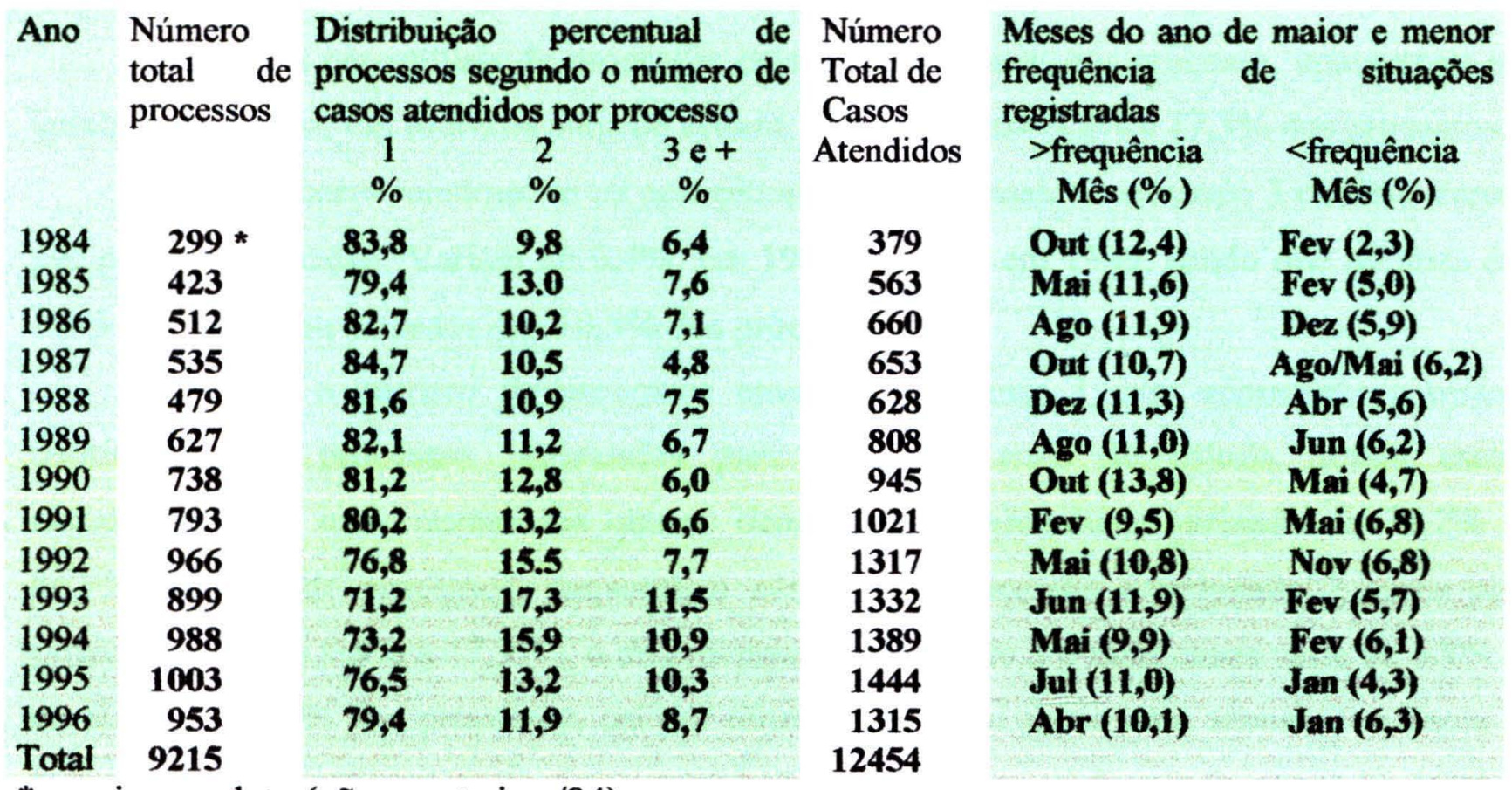

* ano incompleto (não consta jan./84)

Da mesma forma, observa-se no número total de casos atendidos nesses processos, semelhante tendência de crescimento; em 1985, foram 563 casos envolvidos e em 1986, 660. Esse número pouco se altera, caindo para 653 em 1987, e 628 em 1988. Volta a aumentar novamente em 1989 e 1990, passando respectivamente a 808 e 945 casos envolvidos. De 1991 a 1995, continua aumentando para 1021, 1317, 1332, 1389 e 1444 casos atendidos. De 1995 a 1996 cai para 1315 casos atendidos. 
O número de processos/situações registradas no Cartório da Infância e da Juventude de São Carlos mostra, portanto, uma tendência de crescimento, conforme afirmam alguns, embora os anos de 1988, 1993 e 1996, apesar do número importante de processos, mostrem uma pequena queda em relação aos anos anteriores. Assim também ocorre com o número de casos atendidos; mostram aumentos de contingente, de 1984 a 1996.

Quanto ao número de casos atendidos por processo, verifica-se que em 1984, a maior parte desses processos, 83,8\%, envolveu apenas 1 caso, 1 única criança ou adolescentc por processo, enquanto apenas $9,8 \%$ deles envolveu 2 casos, por processo e $6,4 \%, 3$ ou mais crianças e adolescentes, por processo.

Esse mesmo comportamento se repete para os demais anos estudados (Tabela 1). Os percentuais mais expressivos são sempre de processos envolvendo apenas 1 caso, por processo, variando muito pouco, de ano a ano de estudo e correspondeu, em média, a aproximadamente $80 \%$ dos processos.

Quanto aos percentuais de processos envolvendo 2 casos por processo, apresentam-se igualmente baixos, em todos os anos de estudo, variando entre $9,8 \%$ e $17,3 \%$ dos processos.

Ainda menores mostram-se os percentuais dos processos envolvendo 3 ou mais casos por processo/situação. Variam de 6,4\%, em 1984, a 8,7\%, em 1996, sendo que no anos de 1993 a 1995, ficou ao redor dos $10,5 \%$ dos processos.

Assim, se o número de processos envolvendo apenas 1 caso representa o maior contingente de processos registrados para todos os anos de estudo, sendo esses expressivamente mais numerosos que os demais, com percentuais variando de $71,2 \%$ a $\mathbf{8 4 , 7 \%}$ do total de processos, enquanto o número de processos envolvendo 2 casos por processo varia de $9,8 \%$ a $17,3 \%$ e o de processos envolvendo 3 e mais casos varia de $4,8 \%$ a no máximo $11,5 \%$ dos processos, cai por terra a afirmação sobre uma suposta tendência à formação de "gang", por parte dessa população, pelo menos ao longo dos anos de 1984 a 1996, aqui estudados. Nada sinalizou para a suposta "ação/condição grupal" das crianças e adolescentes envolvidos.

Em relação à distribuição percentual de processos, segundo os meses do ano, apresentada na Tabela 1, verifica-se que outubro é o mês do ano de 1984, com maior número de processos; $12,4 \%$ dos processos foram constituídos nesse mês, enquanto fevereiro acusa o menor percentual de processos, 2,3\%, desse ano. Vale dizer, que, considerados todos os anos de estudo, a maior frequência de processos varia de $9,5 \%$ a 
13,8\%, ocorrendo nos meses de outubro, maio, agosto, dezembro, fevereiro, junho e julho; a menor frequência fica entre $2,3 \%$ e $6,8 \%$, correspondendo aos meses de fevereiro, dez, agosto, maio, abril, junho, novembro e janeiro, não sinalizando, portanto, nenhuma tendência para nenhum mês em especial. Diante desses dados, não se pode, como temos visto ocorrer, fazer afirmações acerca de um suposto aumento de casos nos meses de férias; os dados mostram ausência de sustentação para esse tipo de afirmação.

\section{Características das crianças e adolescentes atendidos pela $2^{\text {a }}$ Vara Criminal e da Infância e Juventude da Comarca de São Carlos.}

O universo desses 13 anos estudados é constituído de uma maioria expressiva de casos do sexo masculino. Enquanto esse contingente varia do percentual mínimo de $68,8 \%$ ao percentual máximo de $77,4 \%$ do total de casos, o contingente representado pelo sexo feminino varia entre percentuais de $20,4 \%$ e $29,8 \%$ do total de casos. Contudo, as variações dos contingentes representados pelo sexo masculino, de um para outro ano, são muito pequenas, semelhantemente à variação dos percentuais representados pelo sexo feminino, mantendo-se para todos os anos a expressiva predominância do sexo masculino sobre os percentuais do sexo feminino (Tabela 2).

Nos indagamos por que haveria mais casos de meninos, que casos de meninas na população estudada. A nós parece, que isso tem raízes primeiras em nosso olhar, meninos são mais visados, que meninas; ao mesmo tempo, meninos se expõe mais que as meninas, daí a ação do Judiciário ser mais frequente, com nossos meninos que com nossas meninas. $\mathrm{Na}$ verdade, é preciso olhar para os dois lados, tanto o da população atendida, quanto o do sistema para ela instituído, por isso a única afirmação consistente aqui é a de que passam pelo Fórum mais meninos que meninas; talvez haja tantas meninas quanto meninos nas mesmas condições, mas por algum motivo, eles cheguem ao Fórum e elas não necessariamente.

Quanto à idade das crianças e adolescentes envolvidos, observa-se que, nos anos estudados, o grupo etário mais expressivo é o de 12 a 17 anos de idade, seguido do grupo de crianças com idade menor de 1 ano a 11 anos, havendo um pequeno contingente de $18 \mathrm{e}$ mais anos de idade (Tabela 2). É nítida a preponderância dos percentuais do grupo de 12 a 17 anos de idade, sobre os demais, para todos os anos; o contingente desses casos é pelo menos 2 vezes mais expressivo que o daqueles com menos de 1 a 11 anos de idade. 
Tabela 2. Número total de casos atendidos pelo Fórum de São Carlos, levantados a partir dos processos/situações registrados no Cartório da Infância e da Juventude, de 1984 a 1996, e sua distribuição por sexo e grupos de idade. Comarca de São Carlos, S.P.

\begin{tabular}{|c|c|c|c|c|c|c|c|}
\hline \multirow[t]{2}{*}{ Ano } & \multirow{2}{*}{$\begin{array}{l}\text { Número } \\
\text { Total de } \\
\text { Casos } \\
\text { atendidos }\end{array}$} & \multicolumn{2}{|c|}{$\begin{array}{l}\text { Distribuição percentual dos } \\
\text { casos, segundo o sexo }\end{array}$} & \multicolumn{4}{|c|}{$\begin{array}{l}\text { Distribuição percentual dos casos, segundo grupo } \\
\text { de idade }\end{array}$} \\
\hline & & $\begin{array}{l}\text { Masculino } \\
\%\end{array}$ & $\underset{\%}{\text { Feminino }}$ & $\underset{\%}{<1}$ a 11 & $\begin{array}{c}12 \text { a } 17 \\
\%\end{array}$ & $\begin{array}{r}18 \mathrm{e}+ \\
\%\end{array}$ & $\begin{array}{l}\text { sem informação } \\
\%\end{array}$ \\
\hline 1984 & $377^{*}$ & 70,8 & 27,9 & 27,1 & 56,5 & 1,1 & 15,4 \\
\hline 1985 & 563 & 69,3 & 28,8 & 27,4 & 62,7 & 0,4 & 9,6 \\
\hline 1986 & 658 & 68,8 & 29,8 & 28,3 & 61,8 & 0,8 & 9,1 \\
\hline 1987 & 653 & 72,0 & 27,4 & 27,3 & 60,2 & 0,8 & 11,7 \\
\hline 1988 & 628 & 77,4 & 20,4 & 23,7 & 65,9 & 0,6 & 9,8 \\
\hline 1989 & 808 & 75,4 & 21,0 & 14,4 & 72,5 & 0,5 & 12,6 \\
\hline 1990 & 945 & 76,3 & 21,6 & 17,2 & 71,1 & $\mathbf{0 , 3}$ & 11,3 \\
\hline 1991 & 1021 & 76,3 & 23,3 & 25,6 & 65,5 & 0,2 & 8,7 \\
\hline 1992 & 1317 & 76,3 & 22,9 & 19,2 & 68,3 & 0,5 & 12,1 \\
\hline 1993 & 1332 & 74,4 & 24,6 & 20,3 & 62,7 & 3,0 & 14,0 \\
\hline 1994 & 1389 & 73,1 & 26,4 & 22,0 & 58,4 & 7,2 & 12,4 \\
\hline 1995 & 1444 & 73,8 & 23,6 & 20,4 & 59,4 & 8,5 & 11,6 \\
\hline 1996 & 1315 & 74,0 & 22,1 & 18,0 & 66,4 & 1,7 & 13,8 \\
\hline
\end{tabular}

É interessante notar, que embora o grupo de idade menor de 1 a 11 anos, nos 4 primeiros anos de estudo, apresente uma percentagem ao redor de $27 \%$, passando a decrescer nos anos seguintes, se o compararmos com o grupo de idade entre 12 e 17 anos, poderemos notar, que, no conjunto da série histórica, o comportamento de um é o inverso do outro; exceto pelos anos de 1985, quando os percentuais de ambos os grupos etários aumentam e, 1987 quando ambos diminuem, nos demais anos, quando um aumenta, o outro diminui. Assim, em 1986, 1990, 1991, 1993 e 1994 enquanto ocorre aumento percentual do grupo de idade menor de 1 a 11 anos, diminuem os percentuais do grupo de idade entre 12 e 17 anos; da mesma forma, em 1988, 1989, 1992, 1995 e 1996 enquanto o grupo de idade entre 12 e 17 anos aumenta, o de menos de 1 a 11 anos de idade diminui. Acrescente-se aí, que no ano de 1989 coincidem o menor percentual dos de menos de 1 a 11 anos de idade, com o maior percentual dos de 12 a 17 anos.

Para nós, isso pode estar sugerindo que não estamos diante de um mero aumento do número de casos com idade entre 12 e 17 anos e diminuição dos de menos de 1 a 11 anos, mas de possíveis diferenças/oscilações do próprio sistema que presta o atendimento dessa população. Nesse caso, supomos que o aumento anual do contingente efetivo de crianças e 
adolescentes atendidos seja pouco expressivo, diferentemente do número de casos, que estaria aumentando por conta da entrada da mesma criança ou adolescente, em mais de um processo, ao longo de um mesmo ano e em outros, nos demais anos.

Como o que se tem medida é o número de casos atendidos e não o número de crianças e adolescentes presentes anualmente, parece que o sistema tende a captar/atender mais casos de crianças menores em alguns anos, enquanto em outros se volta/preocupa mais com as maiores.

É importante relatar que há ainda um contingente importante de casos sem informação de idade. O menor percentual desses casos, ocorre em 1991, representando 8,7\% dos casos registrados e o maior em 1984, quando constitui $15,4 \%$ dos casos.

Tabela 3. Distribuição relativa dos casos atendidos pelo Fórum de São Carlos, registrados no Cartório da Infancia e da Juventude, de 1984 a 1996, segundo os grupos etários, para ambos os sexos. Comarca de São Carlos, S.P

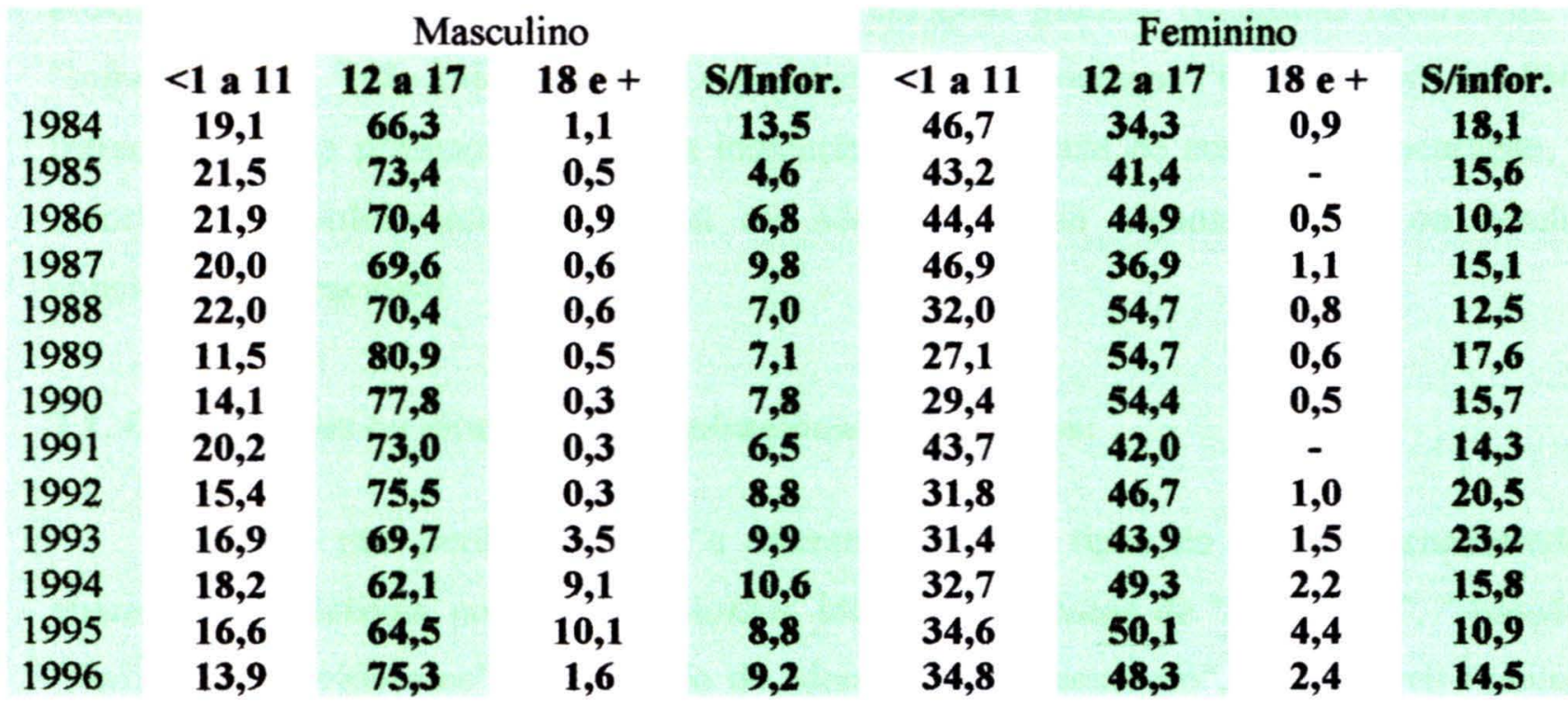

Se observarmos a distribuição dos casos por grupo etário, comparando ambos os sexos (Tabela 3), veremos, que há diferenças entre eles. Enquanto as meninas de menos de 1 a 11 anos de idade, são mais numerosas em 1984, 1985, 1987 e 1991, as de 12 a 17 anos de idade o são em 1988, 1989, 1990, e de 1992 a 1996; apenas em 1986 os contingentes dos dois grupos etários de meninas se equivalem, havendo tantas meninas com menos de 1 a 11 anos de idade, quanto de 12 a 17 anos. No caso dos meninos isso não ocorre; em todos os anos constituem-se em sua maioria de meninos de 12 a 17 anos de idade. 
Isso nos leva a supor, uma vez que os contingentes de casos de meninos são mais expressivos, em todos os anos, que os das meninas e que o grupo com idade de 12 a 17 anos é sempre o mais expressivo no caso dos meninos, que o sistema tende a captar/atender, no caso dos meninos, sempre os mais velhos (entre 12 e 17 anos), enquanto no caso das meninas, parece alternar-se, atendendo em alguns anos (4 dos de estudo) mais casos de meninas menores de 11 anos e em outros (a maior parte dos estudados, 8 anos) mais casos de 12 a 17 anos de idade. Na verdade, para nós, a característica da idade e do sexo, conquanto se refira à população atendida, reflete também, ainda que parcialmente, o comportamento do serviço (ou o tipo de serviço que se pretende oferecer).

\section{Natureza das situações/processos que envolvem as crianças e adolescentes atendidos pela 2a. Vara Criminal e da Infância e Juventude da Comarca de São Carlos.}

Após análise e comparação dos dados encontrados nos Livros de Feitos e nos processos foi possível agrupá-los inicialmente em duas grandes categorias descritivas: os "Infracionais" e "Não Infracionais". O que distingue os processos "Infracionais" dos "Não Infracionais" é a presença de alguma indicação, ou denúncia de suspeita ou acusação, de autoria ou envolvimento de criança ou adolescente em alguma prática ou conduta considerada infracional.

\subsection{Os processos ou situações não infracionais, protetivos:}

Buscando não perder de vista a diferenciação dos tipos de processo encontrados, chamamos Protetivos, aos não infracionais, identificados como de "Abandono", "Adoção", "Pedido de Providências", "Apreensão de Menor", "Representação", "Ação Civil Pública", "Tutela", "Guarda", "Pedido de Internamento", "Abrigo", "Destituição de Pátrio Poder", "Entrega de Filho", "Devolução de filho", "Pedido de Curador Especial", "Colocação em Família Substituta", além dos "Procedimentos Verificatórios" identificados como de natureza protetiva.

Nessa categoria foram, portanto, incluídos os processos que se referem a situações de: Abandono: aparecem registrados como "abandono de criança", "abandono de adolescente", "abandono de filho" e "abandono"; refere-se à situação em que a criança ou adolescente está ou é encontrado sozinho, privado do cuidado dos pais; 
Apreensão de menor: aparecem registradas como "busca e apreensão de menor", "pedido de busca e apreensão", "medida cautelar de busca e apreensão" e "apreensão de menor"; refere-se à busca de uma criança ou adolescente, privado do contato e cuidado de um dos pais, pela ação do outro, que lhe tomou a criança; pode também se referir a uma situação semelhante à do abandono, em que a criança ou adolescente é encontrado sozinho, sem os pais;

Tutela: aparecem registrados como: "pedido de tutela", "pedido de tutor" ou apenas "tutela"; ocorrem quando a criança ou o adolescente está sem representante legal ou, confurme descrito no art. 26 do Código de Menores (BRASIL, 1979), "em benefício do menor em situação irregular que carecer de representação permanente". A tutela implica, tanto pelo Código de Menores (art. 26, par. único), quanto pelo ECA (BRASIL, 1990) (art.36, par. único), "necessariamente o dever de guarda";

Guarda: aparecem registrados como "guarda", "pedido de guarda provisória", "pedido de guarda", "guarda definitiva", "guarda e responsabilidade", "termo de guarda", "pedido de guarda por tempo indeterminado", "pedido de guarda com finalidade de adoção", "pedido de entrega sob guarda e responsabilidade", "guarda e responsabilidade provisória", "regularização de guarda", "modificação de guarda" e "pedido de cancelamento de guarda"; segundo o texto da lei, a guarda "obriga à prestação de assistência material, moral e educacional", no caso do ECA (art.33), "à criança ou ao adolescente", no caso do Código de Menores (art.24) "ao menor"; "conferindo a seu detentor o direito de opor-se a terceiros, inclusive aos pais", igualmente em uma e outra dessas leis;

Destituição de Pátrio Poder: aparecem registrados como "pedido de destituição de pátrio poder" ou apenas "destituição de pátrio poder"; a suspensão ou perda dos poderes dos pais, com relação ao filho, se aplica, de acordo com o art.24 do ECA, quando ocorre "descumprimento injustificado dos deveres e obrigações..." exercidos pelos pais, tais como "sustento, guarda e educação dos filhos menores...", ou, no caso do Código de Menores, art.44, quando os pais "derem causa à situação irregular do menor" ou "descumprirem, sem justa causa as obrigações previstas no artigo 43...", que se referem à "obrigação de submeter o menor a tratamento". Pelo art. $2^{\circ}$ do Código de Menores, "considera-se em situação irregular o menor: ...privado de condiç̃es essenciais à sua subsistência, saúde e instrução obrigatória; ...vítima de maus-tratos ou 
castigos imoderados impostos pelos pais ou responsável; ...em perigo moral, devido a ....encontrar-se, de modo habitual, em ambiente contrário aos bons costumes ....exploração em atividade contrária aos bons costumes; ...privado de representação ou assistência legal, pela falta eventual dos pais ou responsável; ...com desvio de conduta, em virtude de grave inadaptação familiar ou comunitária; ...autor de infração penal". Podem ocorrem também nas situações registradas como "Entrega de filho"; (arts. 22, 23, 24 e 129, inc. X; ECA); (arts. $2^{\circ}, 42,43,44,45,95 /$ inc. II e IV, 98, e 104, Código de Menores);

Entrega de filho: são assim registradas as situações em que ocorre a entrega do filho, pela mãe ou pelo pai, à guarda do Poder Judiciário, mediante o que desistem dos seus direitos de pais, com relação àquele filho;

Devolução de filho: aparecem assim registradas as situações em que o pai, ou a mãe, tenho entregado o filho a alguém, se arrepende de o haver dado, desiste de abrir mão do filho, procurando o Fórum para conseguir tê-lo de volta;

Abrigo: aparecem registrados como "pedido de abrigo em entidade não governamental", "regularização de abrigo em entidade não governamental", "regularização de abrigo em entidade particular", "regularização de abrigo", "pedido de abrigo", "pedido de regularização"; se no Código de Menores (BRASIL, 1979), o abrigo não está explicitamente definido, deduzindo-se tratar-se de acolhimento em entidade, uma vez identificada a "situação irregular do menor", pelo ECA (BRASIL, 1990) art. 98, tratase de medida de proteção, e como tal aplicável "sempre que os direitos reconhecidos nessa Lei forem ameaçados ou violados", mas, neste caso, em especial, conforme o art. 101, par. único, a medida é "provisória e excepcional, utilizável como forma de transição para a colocação em família substituta, não implicando privação de liberdade";

Colocação em familia substituta: aparecem registrados como "colocação familiar" e "colocação em lar substituto"; ocorre quando não é possível a permanência da criança ou adolescente na família natural e se dá mediante guarda, tutela ou adoção, de acordo com o art. 28 do ECA e art. 17 do Código de Menores. (ECA; art. 165 a 170; art. 28 a 32); (Código de Menores; art. 14, inc.III; art. 17 a 20);

Adoção: aparecem registrados como "pedido de adoção", "adoção simples", "adoção", "adoção plena", "pedido de adoção para casal brasileiro", "pedido de adoção para 
casal estrangeiro" e "pedido de inscrição para adoção"; pelo Código de Menores, arts. 27 e 29, são duas as possibilidades de adoção, a simples e a plena; o Código não diferencia claramente uma e outra, mas define especificamente a adoção plena como sendo a que "atribui a situação de filho ao adotado, desligando-o de qualquer vínculo com pais e parentes..." dando como limite a idade de 7 anos para esta modalidade de adoção; pelo ECA, arts. 40 e 41, não há distinções, é uma única modalidade, "adoção" e esta "atribui a condição de filho ao adotado" sendo o limite de idade, os 18 anos incompletos. (Código de Menores; art. 27 a 37); (ECA; art.39 a 52);

Pedido de internamento: aparecem como "pedido de internamento" e "pedido de internação"; referem-se ao abrigo de criança ou adolescente em instituição não governamental, à semelhança das situações de abrigo. (Não se confunde com a "internação" que implica em restrição de liberdade, pois essa é distinta e aparece, como medida ou sentença, nos processos de natureza infracional);

Pedido de providências: aparecem registrados como "pedido de providências" ou ainda "proteção à criança" e "proteção ao adolescente"; referem-se à solicitações da comunidade, da equipe técnica do Fórum ou do Conselho Tutelar (no caso do ano de 1994/novembro, data da sua instalação, e posteriores), de medidas destinadas a atender crianças ou adolescentes em situação de carência ou negligência de cuidados básicos, de saúde ou de escola, crianças e adolescentes vítimas de agressão, maustratos, abandono, exploração, ou que se encontram em "ambiente contrário aos bons costumes" (Código de Menores; art. $1^{\circ}$ ); podem também ser descritos como pedidos de medidas de proteção, consequentes à identificação da situação de violação de qualquer dos direitos reconhecidos na lei (ECA; art. 98); alguns desses processos são de natureza coletiva, referindo-se a situações que envolvem várias crianças e/ou adolescentes, como as de falta de transporte escolar para crianças da zona rural, falta de policiamento preventivo para escola, descumprimento de convênio para atendimento de saúde, evasão escolar e pedido para coibir carona de bicicleta em traseira de ônibus. As situações de providências ou procedimentos para proteção da criança ou adolescente, também aparecem através dos processos registrados como Representação;

Pedido de curador especial, aparecem quando os interesses do adolescente ou da criança colidem com os do pai; nesse caso ( 1 único encontrado) o próprio representante do 
Ministério Público foi nomeado para representar e defender os interesses do adolescente (art. 142, par. único) (BRASIL, 1990).

Ação Civil Pública, aparece quando, entendendo estar ocorrendo violação do direito da criança ou do adolescente, o Ministério Público oferece representação contra o agente dessa violação, tendo em vista a proteção do direito dessa criança ou adolescente; (exemplo: proc. 676/96, infr. art. $5^{\circ}, 15,17$ e 70 do ECA); (art. 201, inc. V; ECA);

Processo ou procedimento verificatório, tanto podem ser caracterizadas como infracionais como podem ser descritas como protetivas, porque se referem tanto a situações de uma natureza, quanto a de outra. Referem-se a denúncias de violência, maus-tratos ou agressão contra a criança ou adolescente; nesse caso são consideradas protetivas e aparecem em apenas 3 dos anos estudados (1990, 1991 e 1994). Outros são considerados infracionais, porque referem-se a situações, em que se supõe a ocorrência de prática de ato infracional pela criança ou adolescente. Nesses casos, o que nos parece, foi uma forma de registro diferente para a mesma coisa, ou seja, o que antes era registrado como "sindicância" e depois foi substituido por "apuração de ato infracional de adolescente", também apareceu registrado como "procedimento verificatório" em um dos anos estudados, no caso o de 1990.

\subsection{Os processos ou situações infracionais.}

Nessa categoria incluímos todos os processos de "Apuração de Ato Infracional de Adolescente" e "Sindicância", envolvendo crianças e adolescentes denunciados por suspeita ou acusação de autoria ou envolvimento, em alguma prática ou conduta considerada infracional. Utilizando esse mesmo critério, foram incluidos nessa categoria os processos registrados como "fuga de menor", "autos de entrega", e "procedimento ou processo verificatório de criança ou adolescente", identificados como infracionais.

Para os processos dos anos relativos à vigência do Código de Menores (BRASIL, 1979), refere-se à "autoria de infração penal" (art. $2^{\circ}$, inciso VI, Código de Menores); para os processos dos anos relativos à vigência do Estatuto da Criança e do Adolescente (BRASIL, 1990), portanto julho/1990 em diante, o ato infracional refere-se à "conduta descrita como crime ou contravenção penal" (art. 103; ECA). A referência, portanto, para os anos anteriores a 1990, é o Código Penal (BRASIL, 1940); para os anos seguintes, além do Código Penal, a Lei das Contravenções Penais (LCP) (BRASIL, 1941). 
Na descrição das "situações infracionais", obtida a partir da leitura e análise dos processos de "sindicância" e "apuração de ato infracional de adolescente", incluindo os de "averiguação", dos anos de 1986, 1991 e 1996, muitos foram os tipos identificados nos processos. Constatadas as semelhanças entre os mesmos, foi possível agrupá-los e obter categorias descritivas, nomeadas a partir de dois critérios; um deles é a frequência com que aparece nos registros dos Livros, pelo Cartório, o outro é a interpretação da situação, contida nos dados registrados nesses processos. Busca-se, ainda, a identificação de possíveis ou supostas equivalências com os tipos definidos por Lei, como e de ato infracional, "conduta descrita como crime ou contravenção penal", no caso do ECA (art. 103) ou como infração penal, caso do Código de Menores (BRASIL, 1979).

\section{As categorias indicativas da natureza infracional das situações estudadas, obtidas foram as seguintes:}

Arma - inclui os processos descritos como: "porte de arma", "porte de facão", "porte de canivete", "porte de alicate e muchaco", "porte de arma de fogo", "porte de punhal"; inclui o porte de 1 a 3 tipos de arma; além desses, "porte de cápsula de revolver", "disparo com arma", "disparo com espingarda de chumbinho", "averiguação sobre disparo com arma", "averiguação sobre tiro", "disparo de tiros de espingarda"; incluídas as "averiguações relativas à arma...". Essa categoria encontra equivalência com o art. 19 da LCP (BRASIL, 1941): "trazer consigo arma fora de casa ou de dependência desta sem licença da autoridade". Se compararmos o teor do artigo, com o que encontramos descrito, muitos deles não correspondem, de fato a "porte de arma".

Direção de veículo - inclui os processos descritos como: "direção de veículo", "condução de veículo", "pilotando motocicleta", "pilotando mobilete", "posse de mobilete", "uso de mobilete", "averiguação sobre direção de veículo", "colisão com moto", "acidente com moto", "acidente com mobilete", "colisão com veículo", "direção e colisão com veículo", "direção e acidente com veículo", "atropelamento, direção e colisão com moto", "pilotando moto e atropelamento", "direção e acidente com moto", "direção sem habilitação", "averiguação sobre direção de veículo com acidente", "direção perigosa"; refere-se à direção de veículo (carro, moto, mobilete) sem habilitação e direção de veículo com acidente (colisão com outro veículo, ou atropelamento, ou 
ainda acidente sem colisão), previstos nos artigos 32 e 34 da LCP (BRASIL, 1941); equivale, pelo artigo 32 a "dirigir, sem a devida habilitação, veículo na via pública, ou embarcação a motor em águas públicas" e, pelo artigo 34 a "dirigir veículos na via pública, ou embarcações em águas públicas, pondo em perigo a segurança alheia". Comparando-se o previsto na lei com os processos descritos, parece haver aqui muito maior correspondência entre a situação registrada com o que os artigos prevêem, do que a observada em outros casos, como os de porte de arma. Chamou-nos a atenção, a não identificação de diferenças nos procedimentos relativos àquelas dessas situações, que envolveram algum tipo de acidente, que resultou em ferimento, ora no próprio adolescente, ora em outra pessoa, ora em ambos. Independente do número de casos em que ocorrem, os acidentes, são, para nós, possíveis sinalizadores de gravidade desse tipo de situação, porque remetem-nos ao risco de vida e à integridade física, tanto do próprio adolescente, quanto das outras pessoas, que transitam pelas vias públicas.

Entorpecente - inclui os processos descritos como: "porte de maconha", "maconha", "cocaína", "fumando maconha", "uso de maconha", "uso de cola", "cheirando cola"; "porte de entorpecente", "droga", "apresentação de substância tóxica", "cheirando thiner", "averiguação sobre tóxico", "averiguação sobre entorpecente", "averiguação sobre tráfico de entorpecente", "vendendo maconha", "tráfico de drogas", "transporte de droga para a cadeia". Nesses casos a equivalência encontrada foi com a Lei 6368/76, que dispõe sobre a "prevenção e repressão ao tráfico ilícito e uso indevido de substâncias entorpecentes ou que determinem dependência física ou psíquica..." (BRASIL, 1976); em especial em 3 de seus artigos: o 12 , o 14 (que remete ao art. 13) e o 16. Embora a riqueza do detalhamento previsto em lei, o que no mais das vezes se viu nesses processos, é que os mesmos se constituem de suspeita de uso ou porte de alguma substância tida como entorpecente; raramente se encontra o que se poderia chamar de fornecimento ou tráfico. O que nos parece é que alguns dos casos envolvidos nesse tipo de situação, quando se confirmava a presença da substância tóxica, faziam uso dela, ou eram usados para transportá-la.

Furto - foram incluídos aqui, os processos descritos como: "furto", "tentativa de furto", "averiguação sobre furto", "apreensão de objetos", "averiguação sobre tentativa de furto", "apropriação indébita", "suspeita de furto", "averiguação sobre apreensão de 
objetos"; as "tentativas..." e "suspeitas...", embora constituam situações diferentes, foram incluidas, porque se constatou que sofrem os mesmos procedimentos. $\mathrm{O}$ estudo dessas situações mostrou que há estreita equivalência com o art.155, do Código Penal (BRASIL, 1940), que define furto, como o "subtrair para si ou para outrem, coisa alheia móvel" e com o art.168, que trata da "apropriação indébita", expressão que define o ato de "apropriar-se de coisa móvel, de quem tem a posse ou a detenção". Contudo, mostrou também, o quanto pode ser questionável a constituição do "crime de furto" propriamente dito, pelo adolescente, quando se levam em conta elementos fundamentais, como as provas de materialidade e autoria do fato, indicadas nos registros desses processos, mas não necessariamente presentes. Evidência incontestável disso é que em expressiva parte desses processos, a autoridade judiciária acaba determinando, como se verá mais adiante, o arquivamento do feito.

Roubo - inclui os processos descritos como: "roubo", "averiguação sobre roubo", "tentativa de roubo"; também aqui encontramos correspondência com Código Penal (BRASIL, 1940), em seu artigo 157, que define roubo como o "subtrair coisa móvel alheia, para si ou para outrem, mediante grave ameaça ou violência à pessoa, ou depois de havê-la por qualquer meio, reduzido à impossibilidade de resistência". Embora haja correspondência entre o descrito e o definido por lei, quando isso se confirma, esses casos são raros, como se verá adiante, na descrição dos contingentes encontrados para cada tipo de situação infracional estudada.

Danos - aparecem descritos como: "danos", "danos no muro da residência", "averiguação sobre danos", "depredação", "atirando pedras", "pixando o muro", "quebrando o muro", "suspeita de incendiar matagal", "jogar bomba na garage", "jogar bomba na escola". $O$ art. 163 do Código Penal, caracteriza o dano pelo "destruir, inutilizar ou deteriorar coisa alheia". O que nos pareceu nesses casos é que embora a descrição encontrada se assemelhe ao previsto em lei, o que nem sempre se confirma é a autoria do ato.

Agressão - ai se incluem os processos descritos como: "agressão", "agressão mútua", "tentativa de agressão", "vias de fato", "averiguação sobre agressão", "lesão corporal", "lesão corporal dolosa", "ameaça de lesão corporal". Diferentemente do que ocorre com as categorias anteriores, essa não encontra a mesma correspondência para todas as descrições. Há equivalência com o art. 21 da LCP (BRASIL, 1941), que prevê o 
"praticar vias de fato contra alguém"; segundo a explicação de Damásio de JESUS (1997), vias de fato "constituem violência contra a pessoa sem produção de lesões corporais". Há também equivalência com o art. 129 do Código Penal (BRASIL, 1940), que caracteriza a "lesão corporal" pelo "ofender a integridade corporal ou a saúde de outrem". No mais, o que se observa é a falta da descrição do tipo de agressão, já que essa poderia ser física ou verbal; estudados os casos, constatou-se que as descrições relativas a "agressão" são de natureza física; as descrições relativas a agressões de natureza verbal, vão aparecer como "calúnia, difamação e injúria", previstos entre os "crimes contra a honra" do Código Penal. Muitos desses casos de agressão "física" são na verdade casos de desentendimento, brigas ou discussões entre a criança ou adolescente e colegas, familiares, namorado(a) ou vizinhos que acabam em tapas e pontapés.

Desordens - estão descritos como: "promovendo desordens", "perturbação do sossego", "perturbação do sossego alheio", "perturbação do sossego público", "arruaças", "perturbação da vizinhança". Nos arts. 42 e 65 da LCP (BRASIL, 1941), estão previstos respectivamente a "perturbação do trabalho ou do sossego alheios" e a "perturbação da tranquilidade" que consiste em "molestar alguém ou perturbar-lhe a tranquilidade por acinte ou por motivo reprovável". O que mais se viu nesses processos, é que coisas comuns como jogo de futebol na rua, andar em grupo na ruas, permanecer em frente à escola ou entrar na escola sem ser seu aluno, são facilmente tomadas como perturbação de sossego e promoção de desordens. Parece-nos que muitos adultos tem dificuldade para compreender algumas situações como próprias daquela fase de desenvolvimento.

Rua - nessa categoria colocamos os que aparecem descritos como: "perambulando pela rua", "vadiagem", "pedindo esmola", "mendicância", "distribuindo papeizinhos". Para nossa surpresa, encontramos artigos na LCP, que prevêem a "vadiagem" (art.59) e a "mendicância" (art. 60). Seguindo as explicações de Damásio de JESUS (1977), "o objeto da contravenção", "bem ou interesse lesado pela contravenção", seriam os "bons costumes"; de acordo com esse autor, no que diz respeito à vadiagem, "o legislador considera que a conduta ociosa leva à delinquência". Isso, nos parece, explica a existência de norma coibitiva desse tipo de situação, que certamente tem outras possibilidades de interpretação. 
Estelionato - aqui agrupamos os descritos como: "estelionato", "tentando passar cheque sem fundo", "uso de moeda falsa", "falsificação de assinatura", "adulterou cheque". Como define o Código Penal, em seu capítulo VI, que trata do estelionato e outras fraudes; mais especificamente no seu art. 171, caracteriza-se por "obter para si vantagem ilícita, em prejuizo alheio, induzindo ou mantendo alguém em erro, mediante artificio, ardil ou qualquer outro meio fraudulento". O que nos parece, do estudo dessas situações é que, no mais das vezes, a ação da criança é resultado da condução de um adulto.

Receptação - os que estão descritos como: "receptador", "receptação". De acordo com o Código Penal, em seu art. 180, refere-se ao ato de "adquirir, receber ou ocultar, em proveito próprio ou alheio, coisa que sabe ser produto de crime ou influir para que terceiro, de boa fé adquira, receba ou oculte".

Desentendimentos - os que estão descritos como: "desentendimentos", "desinteligência", "briga". Parece haver correspondência, com o capitulo IV do Código Penal, que trata "da rixa"; $o$ art. 137, prevê pena para o ato de "participar de rixa, salvo para separar os contendores". Na verdade, o que nos parece, pela leitura desses processos, é que se constituem de brigas ou desavenças, que não justificariam uma intervenção judicial.

Ofensas - estão descritos como: "ofensas", "injúria", "perjúrio", "calúnia", "difamação"; nesses casos encontra-se equivalência no Código Penal (BRASIL, 1940), nos atos considerados crimes contra a honra, art.138 ("calúnia"), art.139 ("difamação") e art. 140 ("injúria").

Ameaça - os que estão descritos como: "ameaça", "ameaça de morte", "averiguação sobre ameaça", "ameaça de agressão". Facilmente identificável a correspondência com o Código Penal, em seu art. 147, que trata da "ameaça", caracterizando-a pelo ato de "ameaçar alguém, por palavra, escrito ou gesto, ou qualquer outro meio simbólico, de causar-lhe mal injusto e grave".

Homicídio - os que estão descritos como: "homicídio", "tentativa de homicídio". Embora a correspondência com o art. 121 do Código Penal , que define o "homicídio simples", como o ato de "matar alguém", pelo estudo desses processos, cujo número de casos foi pequeno em relação às demais categorias de situação infracional, concluímos pela não necessária correspondência, na medida em que algumas situações estudadas, mais se 
identificam com o art. 129 , em seu parágrafo $3^{\circ}$, qual seja, a "lesão corporal seguida de morte".

Suicidio - aqui agrupamos os processos que, para nós, representam tentativas contra a própria vida e, que aparecem registrados como: "tentativa de suicídio", "ingestão de remédios", "ingestão de comprimidos", "ingestão de produto ácido", "tentativa de envenenamento". Relativamente ao suicídio, o Código Penal prevê, em seu art. 122, o "induzimento, instigação ou auxílio a suicídio". Damásio de JESUS (1997a), esclarece que "leva-se em consideração o ato da vítima, que vem a destruir a própria vida". Que "é característica do tipo que o ofendido execute um ato de que decorra, alternativamente, sua morte ou lesão corporal de natureza grave". E que "se o ato de destruição é realizado pelo próprio agente, responde por delito de homicídio". Estranhamente para nós, o ato que traduz uma tentativa contra a própria vida pode ser tomado como "crime" e não como situação de fragilidade emocional, que pede intervenção especializada; felizmente, contudo, nos raros casos encontrados em nosso estudo, a autoridade judiciária decidiu pelo arquivamento dos mesmos. Ao mesmo tempo, infelizmente, não avançou no sentido da compreensão do fato, para além do apenas não punir.

Alcool - bebida assim nomeamos e reunimos os que estão descritos como: "ingestão de alcóolica"; "embriaguez". Os processos dessa natureza, que estudamos apresentam parcial correspondência com o art. 62, da LCP (BRASIL, 1941), onde o mesmo diz do "apresentar-se publicamente em estado de embriaguez", mas isso não ocorre, quando o caracteriza: "de modo que cause escândalo ou ponha em perigo a segurança própria ou alheia". Isso não identificamos nas situações estudadas.

Sexualidade - nessa categoria colocamos os que estão descritos como: "sedução", "tentativa de estupro", "averiguação sobre estupro", "estupro", "atentado violento ao pudor", "suspeita de tentativa de estupro", "atos obscenos", "relações sexuais", "conjunção carnal", "atos libidinosos", "tentativa de agarrar a vítima", "averiguação de ato obsceno", "importunou ofensivamente o pudor". Buscando equivalências, entre os processos estudados e as leis de referência, encontramos no capítulo I (dos crimes contra a liberdade sexual), do título VI, que trata dos crimes contra os costumes, do Código Penal, pelo menos 3 artigos com os quais se pode buscar alguma correspondência. $\mathrm{O}$ art. 213, que define o "estupro", como o ato de "constranger 
mulher à conjunção carnal, mediante violência ou grave ameaça"; o art. 214, que define o "atentado violento ao pudor", como o ato de "constranger alguém, mediante violência ou grave ameaça, a praticar ou permitir que com ele se pratique ato libidinoso diverso da conjunção carnal e o art. 217, que trata da "sedução" caracterizando pelo ato de "seduzir mulher virgem, menor de 18 (dezoito) anos e maior de 14 (quatorze), e ter com ela conjunção carnal, aproveitando-se de sua inexperiência ou justificável confiança. $\mathrm{O}$ que nos chamou a atenção no estudo desses processos é o quanto os mesmos diferem na apuração da autoria, comparativamente aos demais tipos de situação infracional; utiliza-se do laudo de exame de corpo de delito, como no caso das agressões, basicamente como prova, e se ouve os envolvidos, concluindo-se de forma simples, em geral, sem outros desdobramentos. Dão a sutil impressão de que não são tidos como "coisas graves".

Mal-definidos - aqui agrupamos os processos, em que o suposto ato infracional ou não estava descrito, ou não estava claro de que se consistia a infração; aparecem registrados como: "corrida de taxi sem pagar", "comer e beber sem pagar", "jogando snooker", "mexendo em veículo", "mexendo numa moto", "atitude suspeita", "aborto", "averiguação", "queda acidental", "atropelamento", "atropelamento de bicicleta", "acidente com bicicleta", "acidente com vítima", "passando trotes em orelhão público", "conduzindo uma carroça", "oferecendo pinga à crianças", "passar pinga para preso na cadeia", "violação de domicílio", "entrou em domicílio alheio", "invasão de propriedade", "desaparecimento de menor", "obrigava a vítima a ficar em casa", "direção, resistência e agressão", "ato anti-social", "conduzindo uma carroça", "má conduta", "crueldade contra animais", "perseguição".

Fuga de casa - reunimos nessa categoria os processos registrados como "fuga de casa", "fuga de menor", "menor fugitivo", ou simplesmente "fuga"; não encontramos dados nesses processos que nos possibilitassem estabelecer correspondência com a lei, que motivassem esses registros; alguns desses casos, nos deixaram em dúvida, se se tratava de fuga ou de desaparecimento, apesar de constar no Boletim de ocorrência o registro de "fuga" e do procedimento ser o de apuração de suposto delito; a despeito da dúvida não encontramos, nesses processos, procedimentos voltados para a possibilidade de desaparecimento. 
Resultado de nossas observações nesses processos, é oportuno ressaltar, que todos esses processos, cuja natureza é infracional, se distinguem dos não infracionais, de natureza protetiva, por uma outra especificidade. Enquanto esses mobilizam procedimentos judiciais, para avaliar e interferir diretamente sobre a conduta de uma criança ou adolescente, supostamente infracional, criminosa ou contravencional, tendo em vista a "correção" da criança ou adolescente, os não infracionais, protetivos mobilizam procedimentos judiciais, para avaliar e interferir sobre a conduta de adultos, para proteger a criança e o adolescente supostamente ameaçados ou expostos a riscos, sofrimento, negligência abandono ou violência.

Da busca de equivalências e correspondência entre o que está descrito e o que a lei prevê, restou conosco a confirmação do uso do Código Penal como a principal referência, para avaliação da conduta do adolescente. De fato, os dados mostram como "seus artigos" servem de guia para a leitura de um contingente expressivo das situações que envolvem adolescentes. Resulta daí uma indagação para nós. Se esse é o parâmetro criado para normatizar a conduta do sujeito, que já alcançou a maioridade legal, de tal modo que pode ser responsabilizado por cada aspecto da conduta considerada ou descrita como crime ou contravenção penal, como pode ser usado igualmente no caso do adolescente, uma vez que, não havendo alcançado a maioridade penal/legal, não tem a condição legal de responder pelos próprios atos, razão pela qual a lei prevê "seu responsável legal"? A despeito do art. 104 do ECA (BRASIL, 1990), que o coloca como "inimputável" e da sua "condição peculiar" de "pessoa em desenvolvimento", definida também pelo ECA, em seu art. $6^{\circ}$, isso não impede a leitura que caracteriza sua conduta por infracional; se levarmos em conta, o art. 103 do ECA, e o tomarmos isoladamente, isso se justifica, uma vez que, segundo o mesmo, "considera-se ato infracional a conduta descrita como crime ou contravenção penal". Seria a nossa dúvida própria daquele que transita por uma área, da qual não conhece bem os instrumentos? Não haveria, talvez, problemas na homogeneidade do próprio instrumento, por exemplo, na articulação, ou aplicação simultânea, de artigos que se orientam por pressupostos diferentes, conquanto digam respeito ao mesmo objeto? 


\subsection{Outros tipos de situação ou processo: Administrativos, Mal-definidos e Precatórias.}

Encontramos ainda, outros processos, de natureza diversa à "infracional" ou "não infracional", que podem ser caracterizados, a título de identificação, como procedimentos "Administrativos" e que incluem: "atestado"; "pedido de retirada de fundo de garantia"; "pedido de alvará", para franquia de atividade à entrada de crianças ou adolescentes; "pedido de registro ou certidão de nascimento"; "retificação de registro de nascimento"; "pedido de diretrizes do juizado para internação"; "pedido de autorização para estudo noturno"; "pedido de autorização para viagem" e "pedido de autorização para viagem para o exterior". Da mesma forma foram entendidos e, portanto, aí incluídos os processos registrados como "pedido de autorização para carteira de trabalho", "pedido de autorização para trabalho" e "autorização para trabalho noturno", embora não sejam processos de natureza exclusivamente administrativa, uma vez que estão condicionados ao parecer do Juiz da Infầncia e da Juventude, quanto às condições, limites e circunstâncias relativas ao tipo de atividade a ser exercida, para essas autorizações. Essa inclusão foi adotada em função da não relevância do detalhamento dessas informações para os objetivos desse estudo. Além desses, e pela mesma razão, foram igualmente identificados como "administrativos" os processos registrados como "auto de infração", "infração administrativa" e "apuração de irregularidade em entidade de atendimento". Isto porque embora esteja presente a natureza infracional, esta se refere à uma instituição ou entidade (não observação da legislação pertinente ou das condições necessárias à entrada e permanência de crianças ou adolescentes no local); além do que, os procedimentos adotados nesse tipo de situação são essencialmente administrativos (senão burocráticos), tais como regularização da situação com pedido de alvará ou pagamento de multa.

Alguns dos processos não foram incluídos em nenhuma dessas categorias de natureza, dada a dificuldade de identificar a sua natureza, razão pela qual optamos por discriminá-los como "Mal-definidos". Nessa condição colocam-se os processos registrados como: "averiguação" e "menor em situação irregular".

Finalmente, há processos/situações, que aparecem registrados como "carta precatória" ou "precatória", nome pelo qual identificamos essa como outra categoria, a das Precatórias. Embora se refiram a processos em curso em outras Comarcas (situações autuadas pelos Cartórios dessas Comarcas) e, como tal não se constituam objeto de estudo 
dessa investigação, entendendo-os como parte do contingente aqui estudado, optamos por identificá-los, apresentando inclusive sua frequência no universo estudado. Através dos registros do Cartório, verificamos que além da "Comarca de origem", de onde é encaminhada a precatória (como Araraquara, Ribeirão Preto, São Paulo, Dracena, etc...), consta o registro do respectivo "assunto", que corresponde à sua finalidade ou objetivo. Transcrevemos dos Livros de Feitos alguns exemplos, os quais facilitam a compreensão da natureza dos processos/situações a que se podem se referir essas precatórias: "...realização de estudo social na residência do casal..."; "...apresentação do menor e seu responsáve!..."; "...oitiva informal do menor e da vítima..."; "...inquirição de testemunha..."; "...avaliação psicológica do menor..."; "...dar cumprimento a mandado de adoção..."; "...audiência de advertência do menor..."; "...intimação da sentença e aplicação de L.A...."; "...oitiva do genitor da criança..."; "...citação da genitora..."; "...acompanhamento do menor e da família pelo Conselho Tutelar..."; "...cumprimento de medida sócio-educativa..."; "...intimação da adolescente para comparecer naquela Comarca..."; "...intimação do menor e responsável para audiência de instrução, debates e julgamento..."; "...cancelamento de registro de nascimento..."; "...proceder a busca e apreensão do menor..."; "...intimação dos guardiões da menor para se manifestarem acerca do desejo de adoção..."; "...citação de ... ... ....para destituição do pátrio poder..."; "...intimação do casal para comparecer perante o Juizo para audiência...".

Considerando, portanto, todos os processos estudados, podemos falar de pelo menos cinco grupos ou tipos de processos ou situações, de naturezas distintas: as infracionais, as protetivas, as administrativas, as mal-definidas e as precatórias. Assim entendidas, passamos a analisar quão expressivas são essas situaç̃es, em relação ao total de situações estudadas (Tabela 4). 
4. Magnitude das categorias de situações/processos que envolvem as crianças e adolescentes atendidos pela $2^{2}$ Vara Criminal e da Infância e Juventude da Comarca de São Carlos.

Sobre a expressão de cada contingente no universo de estudo, é marcante a predominância das situações infracionais sobre as demais, do primeiro ao último ano de estudo (Tabela 4). Seus elevados percentuais variam de 56,5\% em 1984, a 74,8\%, em 1989, sofrendo ligeiro declínio a partir desse ano e nos seguintes, voltando a valores próximos aos inicialmente encontrados.

Tabela 4. Série histórica: 1984 a 1996. Número total de processos/situaçôes atendidas pelo Fórum de São Carlos, registradas no Cartório da Infância e da Juventude, e sua distribuiçå̃o percentual, segundo os grupos de natureza identificados, para cada ano de estudo. Comarea de São Carlos. SP.

\begin{tabular}{|c|c|c|c|c|c|c|}
\hline \multirow[t]{2}{*}{ Ano } & \multirow{2}{*}{$\begin{array}{l}\text { Número } \\
\text { total de } \\
\text { processos }\end{array}$} & \multirow{2}{*}{$\begin{array}{c}\text { Distribuição } \\
\text { identificados } \\
\text { Protetiva } \\
\%\end{array}$} & \multirow{2}{*}{$\begin{array}{c}\text { ercentual de } \\
\text { Infracional } \\
\%\end{array}$} & \multirow{2}{*}{$\begin{array}{l}\text { processos, segur } \\
\text { Administrativa } \\
\%\end{array}$} & do os tipos/grupos de & grupos de natureza \\
\hline & & & & & $\begin{array}{l}\text { Mdefinida } \\
\%\end{array}$ & $\begin{array}{c}\text { Precatória } \\
\%\end{array}$ \\
\hline 1984 & 299* & 37,5 & 56,5 & 1,3 & & 4,7 \\
\hline 1985 & 423 & 34,0 & 59,3 & 0,2 & & 6,4 \\
\hline 1986 & 512 & 28,9 & 65,8 & 0,4 & $0, \overline{2}$ & 4,7 \\
\hline 1987 & 535 & 32,7 & 59,3 & & 0,2 & 7,9 \\
\hline 1988 & 479 & 24,4 & 68,3 & 0,2 & 0,2 & 6,9 \\
\hline 1989 & 627 & $\mathbf{1 7 , 1}$ & 74,8 & 0,6 & & 7,5 \\
\hline 1990 & 738 & 18,3 & 73,8 & 1,6 & & 6,2 \\
\hline 1991 & 793 & 25,1 & 66,1 & 0,6 & & 8,2 \\
\hline 1992 & 966 & 22,8 & 66,1 & 1,4 & & 9,6 \\
\hline 1993 & 899 & 24,6 & 58,5 & 2,0 & $\overline{0,3}$ & 14,6 \\
\hline 1994 & 988 & 30,9 & 54,5 & 1,4 & 1,6 & 11,6 \\
\hline 1995 & 1003 & 23,9 & 61,1 & 1,0 & 2,7 & 11,3 \\
\hline 1996 & 953 & 26,8 & 60,2 & 0,9 & $\mathbf{0 , 7}$ & 11,3 \\
\hline
\end{tabular}

O segundo grupo mais expressivo é o das situações protetivas, embora num percentual muito menor que o das infracionais, e isso se repete para todos os anos de estudo. Nota-se uma tendência contrária à das situações infracionais, que tendem a pequenos aumentos, enquanto essas diminuem. $O$ ano de 1989 mostra a coincidência da maior frequência das situą̧ões infracionais (74,8\%) com a menor frequência das situações protetivas $(17,1 \%)$. Embora o comportamento, ao longo dos 13 anos, seja semelhante ao das situações 
infracionais, ora aumentando, ora diminuindo, ao final do período, resultam proporcionalmente bem menos expressivas $(26,8 \%)$ que ao início do período, qual seja 1984, decrescendo dos 37,5\% (1984) para 26,8\% (1996).

Poder-se-ía pensar que, se há aumentos percentuais das situações infracionais, há razões para alguns afirmarem um suposto aumento do que costumam chamar "delinquência ou criminalidade juvenil". Contudo, há que se considerar, não apenas algum aumento devido ao próprio crescimento populacional, como o fato de estarmos trabalhando com o número de casos de crianças e adolescentes atendidos e não com o número de crianças e adolescentes atendidos, o que nos obriga a considerar que "vários" dos "que já foram contados" e "atendidos" retornam, somando-se aos talvez semelhantes contingentes do ano seguinte e demais posteriores, pois conforme constatamos pela leitura dos processos, a mesma criança ou adolescente aparece, muitas vezes, em diferentes anos e situações.

Além disso, há um aspecto no tratamento do problema, que precisa ser considerado. Refere-se ao processo de categorização/classificação por que passa a situação, que pode vir de um Boletim de Ocorrência, por quem o elabora e anteriormente por quem atendeu à situação, ou de um ofício de encaminhamento, pela maneira como é lida ou interpretada a situação por quem o destina ao Juiz, ou mesmo do Cartório, por quem lê e interpreta o conteúdo do ofício ou do B.O e os registra nos Livros; finalmente, passa também pela leitura daquele que faz a autuação do processo. A descrição e interpretação da situação representam parte do nosso processo de apreensão dela, não se constituindo, a nosso ver, característicos dela mesma.

Por conta disso, podemos pensar no quanto o aumento na frequência de um tipo de situação pode ser relativo, dependendo do tipo de leitura ou interpretação dada à essa situação por quem participa direta ou indiretamente do seu processo de apreensão ou constatação, registro e autuação. Ademais, ao afirmar o aumento da criminalidade ou delinquência pelo aumento no número de casos infracionais teríamos de nos indagar de que conceito de criminalidade ou delinquência estaríamos nos utilizando, ao reduzí-lo a esse número.

Quanto às precatórias vão constituir a terceira categoria, com percentuais bem menores que os das situações infracionais e os das protetivas; seus contingentes variam dos $4,7 \%$ em 1984, aos $11,3 \%$, em 1996, mostrando um aumento importante aos longo desses 13 anos. Importante porque, embora se refiram a situações que ocorreram em outra 
Comarca, o sujeito, objeto da precatória, é residente no Município de São Carlos, o que significa que é parte de nossa população.

As situações administrativas apresentam percentuais muito pouco expressivos, relativamente às demais categorias de natureza. São muito pouco frequentes, não alcançando valores acima de 2,0\%, mas ocorrem, dando notícia de situações em que é importante a intermediação do Juizo, como por exemplo nas "ações civis públicas", nas "apurações de irregularidade em entidade de atendimento" ou mesmo na autuação das "infrações administrativas".

No Quadro I, a seguir, visualizam-se todos os tipos de situação para cada uma dessas categorias, assim como suas respectivas frequências em cada um dos anos estudados. Notase, inicialmente, que somente alguns tipos de situação ocorrem em todos os anos; quatro deles são protetivos, referem-se à guarda (GUR), adoção (ADP), pedidos de providência (PPR) e tutela (TUT). Além dessas, também as precatórias (CAT) apresentam registros de ocorrência em todos os anos. 
Quadro 1. Natureza das situações registradas no Cartório da Infância e da Juventude, por categoria e respectivos percentuais, para cada um dos anos estudados: 1984 a 1996. Comarca de São Carlos, S.P.

\begin{tabular}{|c|c|c|c|c|c|c|c|c|c|c|c|c|c|}
\hline PERCENTUAL, & $\begin{array}{c}1984 \\
\%\end{array}$ & $\begin{array}{c}1985 \\
\%\end{array}$ & $\begin{array}{c}1986 \\
\%\end{array}$ & $\begin{array}{c}1987 \\
\%\end{array}$ & $\begin{array}{c}1988 \\
\%\end{array}$ & $\begin{array}{c}1989 \\
\%\end{array}$ & $\begin{array}{c}1990 \\
\%\end{array}$ & $\begin{array}{c}1991 \\
\%\end{array}$ & $\begin{array}{c}1992 \\
\% \\
\end{array}$ & $\begin{array}{c}1993 \\
\% \\
\end{array}$ & $\begin{array}{c}1994 \\
\%\end{array}$ & $\begin{array}{c}1995 \\
\% \\
\end{array}$ & $\begin{array}{c}1996 \\
\%\end{array}$ \\
\hline \multicolumn{14}{|l|}{ PROTETIVA } \\
\hline GUR & 22.4 & 18,9 & 16.0 & 20,0 & 11.3 & 7.7 & 6.2 & 6.3 & 6.4 & 8.0 & 10.8 & 7.6 & 6.2 \\
\hline ADP & 5.7 & 4.7 & 5.9 & 5.6 & 5.6 & 5.1 & 6,4 & 8.2 & 4.0 & 3.8 & 3,8 & 5.9 & 5,9 \\
\hline PIN & 2,3 & 2,6 & 2,0 & 1.1 & 1.5 & 1,3 & 0,8 & & 0.4 & 0,1 & & 0,1 & \\
\hline PPR & 2,0 & 1,7 & 2.1 & 3,4 & 3,5 & 2,2 & 2.8 & 4,0 & 8.0 & 9,6 & 10,9 & 6,3 & 11,9 \\
\hline DPP & 1.7 & 1,7 & 1,2 & 0,4 & 0,2 & & & 0,3 & 0,1 & & & 0.5 & 0.1 \\
\hline $\mathrm{ABA}$ & 1.0 & 1,4 & 0.6 & 1.3 & 1.9 & & & 0,3 & & 0.3 & & & \\
\hline CFA & 0.7 & 0.2 & & & & & & & & & & & \\
\hline TUT & 0.7 & 1.2 & 1,0 & 0,4 & 0,4 & 0,2 & 0.1 & 0.9 & 0,6 & 0.2 & 0,8 & 0,9 & 1,0 \\
\hline APM & 0.3 & & & 0.2 & & & & & & & 0.1 & & 0.2 \\
\hline REP & 0.3 & 1,4 & & 0.2 & & & & & & & & & \\
\hline EDF & 0.3 & 0,2 & & & & 0.3 & 0,3 & 0.6 & 0.2 & 1.1 & 0.9 & 0.5 & 0.9 \\
\hline DFI & & & 0.2 & & & & & & & & & & \\
\hline $\mathrm{RAB}$ & & & & 0.2 & & 0.3 & 1,1 & 4.4 & 3.0 & 1.3 & 2,7 & 1.9 & 0.5 \\
\hline CUR & & & & & & & & & & & & 0.1 & \\
\hline $\mathrm{ACP}$ & & & & & & & & & & 0.1 & & 0.2 & \\
\hline $\operatorname{VER}(\mathbf{P})$ & & & & & & & 0.5 & 0,1 & & & 0.7 & & \\
\hline INFRACIONAL & & & & & & & $(5,4)$ & $(0.1)$ & & & $(0,7)$ & & \\
\hline VER (I) & & & & & & & 4.9 & & & & & & \\
\hline SIN & 56,2 & 59,3 & 65.9 & 59,3 & 68.1 & 74.8 & 65.9 & & & & & & \\
\hline AIA & & & & & & & 3.1 & 66.1 & 66.1 & 58.5 & 54.5 & 61,1 & 60,2 \\
\hline ENT & 0.3 & & & & & & & & & & & & \\
\hline FME & & & & & 0,2 & & & & & & & & \\
\hline \multicolumn{14}{|l|}{ PRECATÓRIA } \\
\hline CAT & 4,7 & 6,4 & 4.7 & 7,9 & 6.9 & 7.5 & 6.2 & 8.2 & 9.6 & 14,6 & 11,6 & 11,3 & 11,3 \\
\hline \multicolumn{14}{|l|}{ MAL-DEFINIDA } \\
\hline AVE & & & 0.2 & 0.2 & & & & & & 0.3 & 1,6 & 2.7 & 0.3 \\
\hline MSI & & & & & 0.2 & & & & & & & & \\
\hline \multicolumn{14}{|l|}{ ADMINISTRT. } \\
\hline PAL & 0.7 & & 0.2 & & & & & & & & & & \\
\hline PRE-RRN & 0.7 & 0.2 & & & & & 0.1 & & 0,1 & & 0,1 & (r) 0,1 & \\
\hline AEN & & & & & & & & & & 0.7 & & & \\
\hline PVE & & & & & 0.2 & & 0.1 & 0.1 & 0.1 & & & & \\
\hline PAV & & & & & & 0.6 & 0.4 & 0,1 & & & & & 0,2 \\
\hline PAT-TRN & & & & & & & 0,5 & 0.3 & & 0,3 & & 0.2 & 0.1 \\
\hline AUI & & & 0,2 & & & & 0,1 & & & & & & \\
\hline IAD & & & & & & & & 0,1 & 1,2 & 0.9 & 1,0 & 0,7 & 0,5 \\
\hline AIE & & & & & & & & & & 0.1 & 0.3 & & \\
\hline DJI & & & & & & & 0,1 & & & & & & \\
\hline ATE & & & & & & & 0,1 & & & & & & \\
\hline RFG & & & & & & & & & & & & & 0.1 \\
\hline
\end{tabular}

\section{Legenda}

$\begin{array}{ll}\text { GUR } & \text { Guarda } \\ \text { ADP } & \text { Adoção } \\ \text { PIN } & \text { Pedido de Internamento } \\ \text { PPR } & \text { Pedido de providências } \\ \text { DPP } & \text { Destituição de pátrio poder } \\ \text { ABA } & \text { Abandono } \\ \text { CFA } & \text { Colocação em família substituta } \\ \text { TUT } & \text { Tutela }\end{array}$




\begin{tabular}{|c|c|}
\hline APM & Busca e apreensão de menor \\
\hline REP & Representação \\
\hline EDF & Entrega de filho \\
\hline DFI & Devolução de filho \\
\hline RAB & Abrigo \\
\hline CUR & Pedido de curador especial \\
\hline $\mathrm{ACP}$ & Ação civil pública \\
\hline $\operatorname{VER}(\mathrm{P})$ & Procedimento verificatório (protetivo) \\
\hline VER (I) & Procedimento verificatório (infracional) \\
\hline $\operatorname{SIN}$ & Sindicância \\
\hline AIA & Apuração de ato infracional de adolescente \\
\hline ENT & Autos de entrega \\
\hline FME & Fuga de menor \\
\hline CAT & Precatória \\
\hline AVE & Averiguação \\
\hline MSI & Menor em situação irregular \\
\hline ADMINISTR & Administrativa \\
\hline PAL & Pedido de alvará \\
\hline PRE-RRN & Pedido de registro ou certidão de nascimento ou retificação de registro de nascimento \\
\hline AEN & Autorização para estudo noturno \\
\hline PVE & Pedido de autorização para viagem ao exterior \\
\hline PAV & Pedido de autorização para viagem \\
\hline PAT-TRN & Pedido de autorização para trabalho e autorização para trabalho noturno \\
\hline AUI & Auto de in fração \\
\hline IAD & Infraça adminitrativa \\
\hline AIE & Apuração de irregularidade em entidade de atendimento \\
\hline DJI & Pedido de diretrizes do juizado para internação \\
\hline ATE & Atestado \\
\hline RFG & Pedido de retirada de fundo de garantia \\
\hline
\end{tabular}

As "sindicâncias" (SIN) aparecem de 1984 a 1990. No final desse ano, 1990, começam a aparecer os primeiros registros de "apuração de ato infracional de adolescente" (AIA), que vão substituir os registros de sindicância, de 1991 a 1996. Essas situações, portanto, de sindicância (SIN) e apuração de ato infracional de adolescente (AIA) mostram a ocorrência das situações infracionais também em todos os anos estudados. $\mathrm{E}$ em dois desses anos, 1984 e 1988, acompanham-se de outros dois tipos de situação infracional, cujos registros ocorrem exclusiva e respectivamente nesses anos: referem-se às situações registradas como "auto de entrega" (ENT) e "fuga de menor" (FME) (Quadro I).

Os percentuais dessas situações infracionais são mais elevados que os de todas as demais situações, em todos os anos estudados, ficando, em média ao redor de 63\%; as situações infracionais chamam de fato a atenção, pois são sempre superiores a $50 \%$ do total de processos, em todos os anos de estudo, chegando a ultrapassar a marca dos $70 \%$ de todos os processos em anos, como os de 1989 e 1990. 
Com relação à guarda e demais situações da categoria protetiva, podemos certamente afirmar que é a situação que mais ocorre, podendo-se daí inferir que há mais casos de crianças e adolescentes necessitados desse tipo de proteção (guarda) que casos de crianças e adolescentes necessitados de outros tipos de proteção (abrigo, adoção, tutela, destituição de pátrio poder, entre outros); por outro lado, entendida como medida, pode-se igualmente supor que a guarda é o procedimento mais frequentemente utilizado em situações protetivas ou, a resposta protetiva mais frequente, nos anos de 1984 a 1989 e 1995, na medida em que haveria a possibilidade de utilização de outros tipos de proteção, por exemplo a "adoção", que podem estar ocorrendo dentro dos próprios processos de guarda.

Semelhantemente à ponderação feita acerca da guarda, com relação às situações protetivas, podemos supor que as situações de natureza infracional ocorrem com muito maior frequência que as demais, ou que "as infrações são mais frequentes que as situações de carência de proteção", contudo, podemos igualmente inferir que como procedimento, ou resposta à situação, a autuação ou seu registro como "sindicância" ou "apuração de ato infracional" é muito mais frequente do que o seu registro ou autuação como protetiva. Na verdade, persiste, para nós, a dúvida acerca da natureza da situação e, portanto, da sua expressão numérica, uma vez que essa situação passa necessariamente pela interpretação de alguém, a partir do que se tomam medidas começando pela sua própria caracterização.

As situações de "guarda" (GUR) correspondem ao maior contingente das situações protetivas, com exceção dos anos de 1990 e 1991, quando a adoção foi maior e, 1992, 1993, 1994 e 1996, quando os pedidos de providência (PPR) as superaram.

As situações relativas à "adoção" (ADP) apresentam percentuais bem menos expressivos que os de guarda (GUR); variam de apenas 5,7\% em 1984 a 5,9\% em 1996. Enquanto procedimento protetivo foi mais utilizado em 1990 e 1991, mas ainda assim, não ultrapassa os $8,2 \%$.

As situações registradas como pedido de "providências" (PPR), de modo inverso ao que ocorre com as situações de guarda (GUR), aumentam não contínua mas gradativamente ao longo dos 13 anos. Passam dos $2 \%$ do total de processos em 1984, a 11,9\%, em 1996, sofrendo ligeiras ascensões e declínios ao longo desses anos (Quadro I).

As situações registradas como "representação" (REP), de natureza semelhante à dos pedidos de providências (PPR), aparecem apenas em 1984, 1985 e 1987; representam 0,3\%, $1,4 \%$ e $0,2 \%$, respectivamente, dos processos desses anos. Podem, segundo nosso 
entendimento, ser tomadas em conjunto com os pedidos de providências, como um percentual a ser somado ao contingente de situações que pedem medidas de proteção, nos anos de 1984, 1985 e 1987.

Quanto às situações de "tutela" (TUT), embora presentes em todos os anos de estudo, apresentam percentuais pouco expressivos, quando comparados com os das situações de guarda, ou de pedido de providências ou mesmo de adoção. A maioria de seus percentuais não ultrapassa $1 \%$ do total de processos de cada ano estudado, exceto em 1985, quando apresenta seu contingente máximo, representado por $1,2 \%$ do total de processos desse ano.

As demais situações categorizadas como protetivas não só não apresentam registros de ocorrência em todos os anos, como apresentam, de maneira semelhante à que ocorre com as situações de tutela, percentuais bem menos expressivos que os das situações de guarda, de pedido de providência e os de adoção.

Ainda entre as categorias protetivas, aparecem os "pedidos de internamento" (PIN), com pequenos percentuais, que progressivamente diminuem; de 2,3\% em 1984, para 0,1\% em 1995, não ocorrendo registro desses pedidos nos anos de 1991, 1994 e 1996. É possível que os registros de pedido de internamento (PIN) estejam desaparecendo e que as situações que necessitam acolhimento em instituição, encaminhadas como pedido de internamento anteriormente ao Estatuto, estejam sendo encaminhadas ou registradas como de abrigo. $\mathrm{O}$ que poderia ser explicado pela própria aplicação do Estatuto, onde 'internação' é termo e medida que implica em privação de liberdade, o que não ocorre com o abrigo. Conforme constatamos pela leitura de alguns processos dessa natureza, esses pedidos, registrados como de "internamento" ou "internação", nos anos estudados, referem-se a pedidos de acolhimento em instituição, não vinculados à privação de liberdade.

As situações relativas a "abrigo" (RAB), aparecem nos registros dos anos de 1987 e entre 1989 a 1996. São inicialmente menos expressivas, até 1990. Em 1991 e 1992 apresentam seus maiores percentuais para os anos estudados, 4,4\% e 3,0\% respectivamente do total de processos desses anos. O ano de 1991 é o primeiro ano seguinte à instituição do Estatuto e nesse ano o percentual máximo das situações de abrigo, 4,4\%, coincide com a não ocorrência de pedidos de internamento (PIN). A partir de 1993, os percentuais das situações de abrigo diminuem, atingindo $0,5 \%$, em 1996, mostrando pequenas oscilações no período (Quadro I). 
Os registros de situações de "abandono" (ABA) aparecem com pequenos percentuais nos anos de $1984(1,0 \%), 1985(1,4 \%), 1986(0,6 \%), 1987(1,3 \%)$ e $1988(1,9 \%)$. Não ocorrem nos anos de 1989, 1990 e 1992. Reaparecem em 1991 e 1993, mas representam apenas $0,3 \%$ dos processos de cada um desses anos. $\mathrm{E}$ nos anos seguintes, novamente não há registros de ocorrência. Parece pouco provável que essas situações não estejam acontecendo nos últimos anos estudados, com a mesma, senão maior frequência, que nos anos iniciais de estudo. O que nos parece é que essas situações podem estar sendo encaminhadas ou registradas como pedidos de providência.

As situações registradas como "colocação em familia substituta" (CFA), apresentam percentuais ainda menos expressivos, que os das demais situações protetivas; correspondendo a apenas $0,7 \%$ e $0,2 \%$, respectivamente, dos processos de 1984 e 1985 . É possível, que enquanto procedimento ou medida para a proteção da criança, ela possa aparecer dentro de processos de adoção ou guarda; contudo, é igualmente provável que seja mesmo pouco utilizada ou preterida em relação a outros igualmente protetivos, também porque depende da disponibilidade de famílias para essa finalidade.

As "destituições de pátrio poder" (DPP) aparecem em 9 dos 13 anos estudados. Além de seus percentuais serem baixos, apresentam declínios no período, de 1,7\% em 1984 a 0,1\% em 1996. Embora em 1989 e 1990, assim como em 1993 e 1994, não apareçam, não se pode, por isso, pensar que não hajam ocorrido, ou que estejam diminuindo, já que, pelo que constatamos, esse tipo de situação pode aparecer como procedimento ou medida, dentro de processos relativos à guarda, à adoção e à entrega de filho.

Ainda no Quadro I, aparecem os processos registrados como "entrega de filho" (EDF), que só não apresentam registros de ocorrência em 1986, 1987 e 1988. Seus percentuais, contudo, são igualmente baixos, comparados aos demais de natureza protetiva.

O registro de situações de "devolução de filho" (DFI), aparece exclusivamente no ano de 1986; corresponde ao registro de uma única situação, que por sua vez, se refere um único caso dessa natureza atendido pela Vara nos 13 anos de estudo. Assim, se poderia pensar, que esse tipo de situação é rara. Nós, contudo, nos indagamos se essas situações não poderiam estar ocorrendo, sem necessariamente passar pelos registros do Cartório, uma vez que o sentimento de arrependimento por ter entregue o filho para adoção foi detectado em processos de outra natureza, por exemplo em alguns registrados como "entrega de filho" ou "pedido de providências". 
Outra situação protetiva que apresenta um único registro de ocorrência é o "pedido de curador especial" (CUR); o único ano em que aparece nos registros é o de 1995 e corresponde a um único caso dessa natureza atendido pela Vara.

As situações registradas como "busca e apreensão de menor" (APM), aparecem apenas em 1984, 1987, 1994 e 1996 e seus contingentes não ultrapassam os $0,3 \%$ dos totais de processos desses anos.

Registros de "processo ou procedimento verificatório", de natureza protetiva, (VER)(P), aparecem em 3 dos 13 anos de estudo; são 0,5\% dos processos de 1990, 0,1\% dos de 1991 e $0,7 \%$ dos de 1994. Não chegam, portanto, sequer a 1,0\%do total de processos desses anos. Para nós, isto não significa que a situação de violência cometida contra a criança ou o adolescente não esteja acontecendo ou, em ocorrendo, que sua frequência não seja expressiva; referências como as de DIMENSTEIN (1995, 1992, 1992a, 1992b) e SANTOS (1987; 1995) nos levam a crer que o que ocorre é a não denúncia desse tipo de situação. Esses, entre outros autores, nos alertam para a existência de um perverso silêncio em torno dessa situação, a da violência contra a criança ou o adolescente. Além disso, ninguém que estude o problema, ou que apenas acompanhe os noticiários, ignora que a busca de providências para esse tipo de situação, pela mãe da criança ou do adolescente ou pelo próprio adolescente, resulta em consequências danosas contra ela ou ele mesmo.

Registros de "ação civil pública" (ACP), aparecem em apenas 2 dos anos estudados, 1993 e 1995. Representam apenas $0,1 \%$ e $0,2 \%$, respectivamente, dos totais de processos desses anos. Se levarmos em conta que esse tipo de situação corresponde também a um tipo de procedimento ou medida do Ministério Público, quando da existência de ameaça ou violação dos direitos da criança e do adolescente, podemos dizer, pelos percentuais encontrados, que o mesmo raramente é adotado, já que sua ocorrência implica necessariamente o seu registro pelo Cartório. Cabe ressaltar, que só ocorre em anos posteriores ao advento do ECA.

Quanto aos contingentes apresentados pelas "precatórias" (CAT), variam, do menor ao maior percentual, entre $4,7 \%$ e $14,6 \%$; entre aumentos e quedas desses percentuais, passam de $4,7 \%$ dos processos de 1984 a 8,2\% dos processos em 1991, chegando a 14,6\% em 1993; diminuem para $11.6 \%$ dos processos, em 1994, mantendo-se em torno desses percentuais nos anos seguintes. Há um progressivo aumento em termos percentuais, se considerarmos os 13 anos de estudo. O contingente de situações, envolvendo crianças e adolescentes, ou 
familiares, residentes ou procedentes de São Carlos, conduzidas em outras Comarcas está, portanto, mostrando aumentos, do nosso ponto de vista expressivos.

Relativamente às situações categorizadas como administrativas, os contingentes são muito pequenos, se comparados com os das situações protetivas, ou mesmo os das precatórias; exceto pelas "infrações administrativas" (IAD), nenhuma delas ultrapassa os $0.7 \%$ do total de processos, em todos os anos estudados (Quadro I). Se levarmos em conta a semelhança de natureza dessas infraçoes administrativas (IAD) com os "autos de infração" (AUI) e as "apurações de irregularidade em entidade de atendimento" (AIE), pociemos tomá-las em conjunto, obtendo percentuais que totalizariam $0,2 \%$ dos processos de 1986, $0,1 \%$ dos de 1990 e de 1991 , igualmente, $1,2 \%$ dos de $1992,1,0 \%$ dos de $1993,1,3 \%$ dos de 1994 e $0,7 \%$ e $0,5 \%$, respectivamente, dos de 1995 e 1996.

É importante destacar ainda, dentre as situações categorizadas como administrativas, as relativas a "pedidos de autorização para trabalho" (PAT-TRN). Aparecem somente nos anos de 1990, 1991, 1993, 1995 e 1996 e com percentuais que, além de muito pouco expressivos, diminuem gradativamente (Quadro I).

Quanto às situações categorizadas como mal-definidas, encontramos pelo menos 2 tipos delas. Um, está registrado como "menor em situação irregular" (MSI); ocorre em 1988 e seu percentual de $0,2 \%$ corresponde a uma única situação, que envolveu apenas 1 caso atendido. O outro, aparece registrado como "averiguação" (AVE), sem qualquer outra especificação. $\dot{E}$ importante saber, que algumas das situações categorizadas como infracionais também aparecem registradas como averiguação, mas se diferenciam daquela porque trazem a descrição do tipo de situação a que se referem, por exemplo, "averiguação sobre furto". Os registros de averiguação mal-definida aparecem nos anos de 1986 e 1987 com percentuais de $0,2 \%$ do total de processos de cada um desses anos; voltam a ocorrer entre os anos de 1993 a 1996, correspondendo a $0,3 \%, 1,6 \%, 2,7 \%$ e $0,3 \%$, respectivamente, dos processos desses anos. Da comparação desses percentuais, pode-se constatar que em 1995 o contingente de situações mal definidas foi bem mais expressivo que nos demais anos.

Considerando a importância das categorias infracionais e protetivas, nos anos estudados, apresentamos na Tabela 5, a distribuição relativa dos casos, segundo os diferentes grupos etários, para essas duas categorias. Constata-se, que, nas situações protetivas, os contingentes mais expressivos, para todos os anos de estudo, são de meninos e 
meninas com idade menor que 1 a 11 anos de idade, ao contrário do que ocorre nas situaç̃̃es de natureza infracional, em que os de 12 a 17 anos de idade são mais numerosos.

Tabela 5. Distribuição relativa dos casos atendidos pelo Fórum de São Carlos, registrados no Cartório da Infincia e da Juventude, de 1984 a 1996, segundo os grupos etários, para as duas principais categorias de situaçâo. Comarca de São Carlos, S.P.

\begin{tabular}{|c|c|c|c|c|c|c|c|c|}
\hline \multirow[b]{2}{*}{ Anos } & \multicolumn{4}{|c|}{ Protetiva } & \multicolumn{4}{|c|}{ Infracional } \\
\hline & $<1$ a 11 & 12 a 17 & 18 e + & s/ infor. & $<1$ a 11 & 12 a 17 & $18 e^{+}$ & $\mathrm{s} /$ infor. \\
\hline 1984 & 61,0 & 13,5 & - & 25,5 & 6,8 & 88,2 & 1,8 & 3,2 \\
\hline 1985 & 70,7 & 16,8 & - & 12,5 & 5,2 & 93,0 & 0,6 & 1,2 \\
\hline 1986 & 77,7 & 14,6 & 0,5 & 7,2 & 5,7 & 88,9 & 0,9 & 4,5 \\
\hline 1987 & 69,9 & 15,5 & 0,9 & 13,7 & 4,9 & 93,3 & 0,8 & 1,0 \\
\hline 1988 & 64,2 & 20,0 & - & 15,8 & 9,6 & 89,2 & - & 0,5 \\
\hline 1989 & 49,6 & 14,3 & 1,5 & 34,6 & 7,7 & 91,0 & 0,3 & 1,0 \\
\hline 1990 & 65,2 & 13,1 & - & 21,7 & 7,7 & 89,3 & 0,4 & 2,6 \\
\hline 1991 & 77,4 & 21,1 & - & 1,5 & 7,4 & 89,3 & 0,3 & 3,0 \\
\hline 1992 & 60,0 & 22,4 & 1,4 & 16,2 & 7,0 & 90,1 & 0,1 & 2,8 \\
\hline 1993 & 59,0 & $\mathbf{3 0 , 0}$ & 0,9 & 10,1 & 5,6 & 85,0 & 3,8 & 5,6 \\
\hline 1994 & 57,8 & 26,6 & 2,0 & 13,6 & 6,1 & 79,7 & 10,3 & 3,9 \\
\hline 1995 & 60,6 & 24,8 & 0,6 & 14,0 & 6,6 & 77,2 & 11,1 & 5,1 \\
\hline 1996 & 49,0 & 22,4 & 2,3 & 26,3 & 2,5 & 94,4 & 0,4 & 2,7 \\
\hline
\end{tabular}

Para nós, não é sem razão, que as "crianças" apareçam mais nas situações protetivas, enquanto os "adolescentes" se concentram nas situações infracionais. Nossas posturas, como nossos olhares, tendem a diferenciar-se, quando nos relacionamos com eles. Acreditamos, que enquanto adultos, nos relacionamos de maneiras distintas com crianças e adolescentes, tendendo a agir de modo mais acolhedor e protetivo, com relação às crianças mais novas e de modo mais disciplinar à medida que se tornam mais velhas. Talvez o exame de nossas próprias atitutes possa nos demonstrar isso. O próprio ECA (BRASIL, 1990) pode nos servir como referência, quando diferencia "crianças" e "adolescentes" não apenas pela idade (art. 20.), mas pela leitura de seu ato (arts. 103, 104 e 105), assim como pela aplicação de medidas (arts. 101, 105 e 112). Se bem observarmos veremos que o capítulo II, do Título III, que trata especificamente "Da prática de Ato Infracional" está concebido com olhares para o adolescente, enquanto o capítulo II, do Título II, que trata "Das Medidas Específicas de Proteção", foi pensado para a criança. Interessante notar que enquanto o Título II prevê entre as medidas, o "abrigo em entidade" o Título III prevê a "internação em 
estabelecimento educacional". Indício importante sobre o nosso olhar "acolhedor" em relação à criança e "disciplinador" em relação ao adolescente.

Podemos, ainda, comparar o número de casos de adolescentes, ou indivíduos com idade entre 12 e 17 anos, atendidos em situações "protetivas", com o número de adolescentes, atendidos em situações ditas infracionais ou ainda comparar o número de situações protetivas envolvendo casos de crianças, ou indivíduos com idade $<1$ a 11 anos com o número de situações protetivas envolvendo casos de adolescentes, ou indivíduos entre 12 e 17 anos. É nítida a predominância de adolescentes atendidos nas situações infracionais, em relação aos com mesma idade atendidos nas situações protetivas, assim como a predominância dos casos com idade $<1$ a 11 anos nas situações protetivas, em relação aos com mesma idade, nas situações infracionais (Tabela 6).

Tabela 6. Frequência de casos de crianças e adolescentes, registrados no Cartório da Infância e Juventude, por tipo de situação em que foram atendidos, grupo etário e sexo, nos anos de 1984 a 1996. Comarca de São Carlos, S.P.

\begin{tabular}{|c|c|c|c|c|c|c|c|c|c|}
\hline \multirow[b]{3}{*}{ Ano } & \multicolumn{4}{|c|}{ PROTETIVA } & \multicolumn{4}{|c|}{ INFRACIONAL } & \multirow[b]{3}{*}{ TOTAL } \\
\hline & \multicolumn{2}{|c|}{$<1-11$ anos } & \multicolumn{2}{|c|}{ 12-17 anos } & \multicolumn{2}{|c|}{$<1-11$ anos } & \multicolumn{2}{|c|}{ 12-17 anos } & \\
\hline & $M$ & $F$ & $M$ & $F$ & $M$ & $F$ & $M$ & $F$ & \\
\hline 84 & 38 & 47 & 11 & 8 & 13 & 2 & 166 & 28 & 313 \\
\hline 85 & 69 & 66 & 17 & 15 & 15 & 3 & 267 & 52 & 504 \\
\hline 86 & 80 & 80 & 8 & 22 & 17 & 7 & 310 & 66 & 590 \\
\hline 87 & 80 & 78 & 21 & 14 & 14 & 5 & 306 & 52 & 570 \\
\hline 88 & 73 & 32 & 19 & 12 & 32 & 9 & 323 & 58 & 558 \\
\hline 89 & 35 & 31 & 8 & 11 & 35 & 13 & 485 & 80 & 698 \\
\hline 90 & 54 & 50 & 11 & 10 & 46 & 9 & 544 & 99 & 823 \\
\hline 91 & 114 & 95 & 33 & 24 & 42 & 8 & 534 & 73 & 923 \\
\hline 92 & 90 & 82 & 39 & 26 & 57 & 7 & 711 & 114 & 1126 \\
\hline 93 & 110 & 83 & 47 & 51 & 39 & 7 & 607 & 91 & 1035 \\
\hline 94 & 127 & 103 & 53 & 53 & 44 & 6 & 542 & 116 & 1044 \\
\hline 95 & 121 & 91 & 53 & 34 & 43 & 17 & 584 & 118 & 1061 \\
\hline 96 & 102 & 85 & 45 & 41 & 20 & & 653 & 91 & 1037 \\
\hline
\end{tabular}

Parece-nos assim pertinente cogitar de uma possível relação entre idade e tipo de situação, como hipótese explicativa para os dados encontrados. Para tanto, não contam apenas os números encontrados, mas todo o processo de caracterização/descrição porque passa a situação original, pela leitura de quem flagra, autua, registra, presencia, acompanha, relata ou informa o fato ou a situação, seja a autoridade policial, o comissário de menor, o 
conselheiro tutelar, o setor técnico do Fórum, a comunidade ou o Cartório e as autoridades judiciárias.

Lembrando que os casos do sexo masculino constituem a maioria da população estudada e que o mesmo ocorre com os casos com idade entre 12 e 17 anos de idade, se os casos com idade entre 12 e 17 anos de idade predominam nas situações ditas infracionais e os com menos de 1 a 11 anos de idade nas protetivas, será que o aumento do número de crianças e adolescentes e o contingente de crianças e adolescentes que participam de mais de uma situação, não apenas ao longo de um, mas de 2, 3 ou mais anos de estudo seriam suficientes para explicar a diferença tão expressiva no aumento do número de casos com idade entre 12 e 17 anos, do sexo masculino, envolvidos nas situações ditas infracionais, em relação aos demais, conforme se observa no Gráfico 1 ?

Talvez isso nos faça indagar acerca do tipo de resposta que temos dado a nossas crianças e adolescentes. Será, de fato, o número de situações de natureza dita infracional, o que é expressivo e o que aumenta gradualmente, ou a tendência da nossa leitura, que se tem tornado mais disciplinar que protetiva? A considerar as constatações oriundas da nossa prática, acerca do quão precocemente nossas crianças tem adquirido autonomia em seus comportamentos, se superando e adolescendo cada vez mais cedo, talvez consequentemente nos tenhamos tornado mais tutores que cuidadores. Se o ECA serve de argumento a nosso favor, como instrumento que vem para mudar, garantindo a proteção integral da criança e do adolescente, nossos resultados não o demostram, já que ao contrário do que se esperaria, um aumento mais expressivo das situações protetivas, do ano de 1991 (ano seguinte à criação do ECA) em diante, o que constatamos é o aumento bem mais expressivo das infracionais. 
Gráf.1. Frequência de casos de crianças e adolescentes registrados no Cartório da Infância e da Juventude, por tipo de situação em que foram atendidos, grupo etário e sexo, nos anos de 1984 a 1996. Comarca de São Carlos, SP.

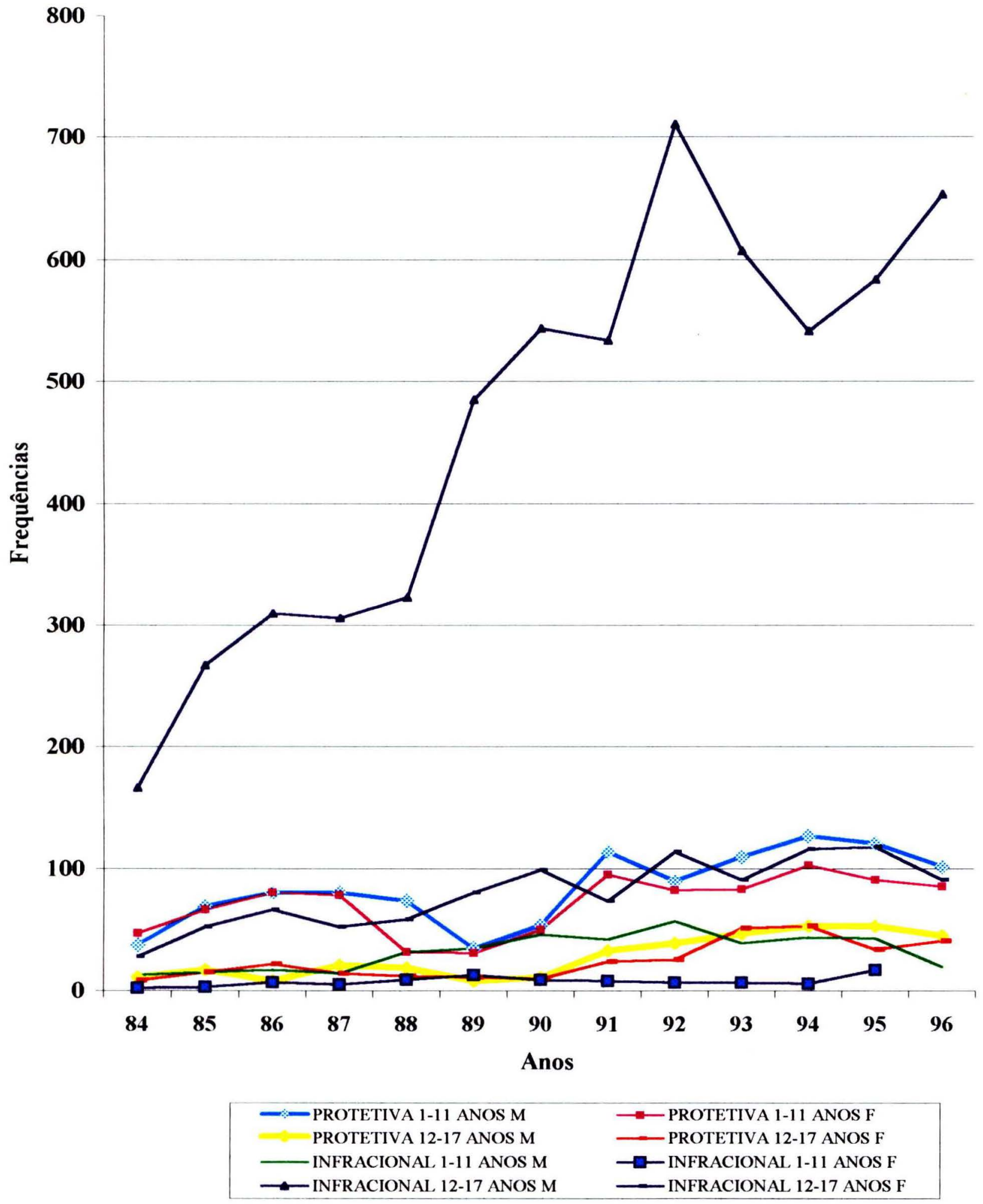




\section{Magnitude das situações de natureza infracional e das medidas respectivamente} aplicadas nessas situações, pelo Juízo da Infância e da Juventude da Comarca de São Carlos.

Vistos os tipos de situações ditas infracionais, encontrados nos processos de "sindicância", do ano de 1986 e nos de "apuração de ato infracional de adolescente", dos anos de 1991 e 1996, passamos à descrição de seus percentuais, bem como das medidas respectivamente aplicadas nessas situações, pelo Juízo da Infầncia e da Juventude de São Carlos, igualmente identificadas nos registros desses mesmos processos. Antes, contudo, de apresentar esses contingentes, cabe rápida explanação acerca de que se tratam essas medidas.

\subsection{Acerca das medidas.}

Tomamos por "medidas", ao conjunto de procedimentos adotados pelo Poder ou autoridades judiciárias no trato das situações ditas infracionais; correspondem às medidas previstas na legislação específica, em vigência nos respectivos anos de estudo, qual seja, o Código de Menores_Lei 6697 de 10/10/79 (BRASIL, 1979), no caso do ano de 1986 e o Estatuto da Criança e do Adolescente Lei 8069 de 13/07/90 (BRASIL, 1990), no caso de 1991 e 1996. Constituem, portanto, as "medidas judiciais", "de assistência e proteção", "aplicáveis ao menor" e "determinadas pela autoridade judiciária", no Código de Menores (Título V, cap. I, arts. 14 e 17 e cap. V, art.59) assim como as "medidas especificas de proteção" e "sócio-educativas" previstas no Estatuto da Criança e do Adolescente (Título II, cap. I, art. 98 e cap. II, arts. 99 a 102; Título III, cap.I, art. 105 e cap. IV, art. 112).

No Quadro 2 apresentamos à esquerda, as "medidas de assistência e proteção", definidas no Código de Menores (BRASIL, 1979) e os respectivos artigos; à direita, colocamos as "medidas específicas de proteção" (art. 101, incisos I a VIII) e "sócioeducativas" (art. 112, incisos I a VII), definidas no Estatuto da Criança e do Adolescente, ECA, (BRASIL, 1990). Propositalmente, as medidas do ECA não obedecem a ordem

original do texto legal, porque adotamos o critério da comparação com o Código de Menores, buscando com isso mostrar onde há mudanças e onde persistem as mesmas proposições. 
Quadro 2. Medidas de "assistência e proteção" (arts. 14, incisos I a VI e 17, incisos I a V) previstas pelo Código de Menores (BRASIL, 1979) e "medidas específicas de proteção" (art. 101, incisos I a VIII) e "sócio-educativas" (art. 112, incisos I a VII), previstas pelo Estatuto da Criança e do Adolescente, ECA (BRASIL, 1990).

\begin{tabular}{|c|c|}
\hline $\begin{array}{c}\text { Código de Menores } \\
\text { Medidas de Assistência e Proteção }\end{array}$ & $\begin{array}{c}E C A \\
\text { Medidas de Proteção e Sócio-educativas }\end{array}$ \\
\hline Art. 14 , inc. I-advertência; & Art. 112 , inc. I - advertência \\
\hline $\begin{array}{l}\text { Art. 14, inc. II - entrega aos pais ou responsável, ou à } \\
\text { pessoa idônea, mediante Termo de responsabilidade; }\end{array}$ & $\begin{array}{l}\text { Art. } 101 \text {, inc. I - encaminhamento aos } \\
\text { pais ou responsável mediante termo de } \\
\text { responsabilidade; }\end{array}$ \\
\hline \multirow{3}{*}{$\begin{array}{l}\text { Art. 14, inc. III - colocação em lar substituto (art. 17: } \\
\text { "...mediante: I - delegação de pátrio poder; II -guarda; } \\
\text { III -tutela; IV -adoção simples; V -adoção plena"); }\end{array}$} & $\begin{array}{l}\text { Art. } 101 \text {, inc. VIII - colocação em familia } \\
\text { substituta. }\end{array}$ \\
\hline & $\begin{array}{l}\text { Art. 112, inc. II - obrigação de reparar o } \\
\text { dano; }\end{array}$ \\
\hline & $\begin{array}{l}\text { Art. } 112 \text {, inc. III - prestação de serviços à } \\
\text { comunidade; }\end{array}$ \\
\hline $\begin{array}{l}\text { Art. 14, inc. IV - imposição de regime de liberdade } \\
\text { assistida; }\end{array}$ & Art. 112 , inc. IV - liberdade assistida; \\
\hline Art. 1, inc. V - colocação em casa de semiliberdade; & $\begin{array}{l}\text { Art. } 112 \text {, inc. V - inserção em regime de } \\
\text { semiliberdade; }\end{array}$ \\
\hline \multirow{8}{*}{$\begin{array}{l}\text { Art. 14, inc. VI - internação em estabelecimento } \\
\text { educacional, ocupacional, psicopedagógico, hospitalar, } \\
\text { psiquiátrico ou outro adequado. }\end{array}$} & $\begin{array}{l}\text { Art. 112, inc. VI - internação em } \\
\text { estabelecimento educacional; }\end{array}$ \\
\hline & $\begin{array}{l}\text { Art. } 112 \text {, inc. VII - qualquer uma das } \\
\text { previstas no artigo } 101 \text {, I a VI. }\end{array}$ \\
\hline & $\begin{array}{l}\text { Art.101, inc. II - orientação, apoio e } \\
\text { acompanhamento temporários; }\end{array}$ \\
\hline & $\begin{array}{l}\text { Art. 101, inc. III - matrícula e frequência } \\
\text { obrigatórias em estabelecimento oficial } \\
\text { de ensino fundamental; }\end{array}$ \\
\hline & $\begin{array}{l}\text { Art. 101, inc. IV - inclusão em programa } \\
\text { comunitário ou oficial de auxilio à } \\
\text { família, à criança e ao adolescente; }\end{array}$ \\
\hline & $\begin{array}{l}\text { Art. 101, inc. V - requisição de } \\
\text { tratamento médico, psicológico ou } \\
\text { psiquiátrico, em regime hospitalar ou } \\
\text { ambulatorial; }\end{array}$ \\
\hline & $\begin{array}{l}\text { Art. 101, inc. VI - inclusão em programa } \\
\text { oficial ou comunitário de auxílio, } \\
\text { orientação e tratamento a alcoólatras e } \\
\text { toxicômanos; }\end{array}$ \\
\hline & Art. 101, inc. VII - abrigo em entidade; \\
\hline
\end{tabular}

O Quadro 2 nos permite observar que proposições ou medidas previstas na lei revogada persistem na lei que a substitui (...mesclam-se velhas idéias e conceitos com novas 
proposições). A leitura dos processos nos deu indícios para pensar que isso pode não ser casual, já que o mesmo ocorre no conteúdo de muitos dos pareceres contidos nesses processos. O que nos parece é que não é fácil nos despregarmos de antigos conceitos, apesar do desejo de colocar em práticas nossas novas proposições.

Da mesma forma, parece persistir na lei "um divisor", separando "os menores em situação irregular desviantes dos não desviantes" (ou os "pobres" dos "delinquentes"). Enquanto a seção I, do Capítulo I (Título V), do Código de Menores (BRASIL, 1979) prevê a colocação em lar substituto, mediante a delegação do pátrio-poder, da guarda, da tutela, da adoção simples e da adoção plena (arts. 17 a 37), a seção II, do mesmo capítulo, trata da aplicação de medidas diferenciadas, quando ocorrem situações envolvendo condutas consideradas infracionais ou "desviantes", como é o caso da "liberdade assistida", aplicável ao "menor em situação irregular", "com desvio de conduta, em virtude de grave inadaptação familiar ou comunitária"(art. 2o.,inc. V) e ao "menor em situação irregular" "autor de infração penal" (art. 20., inc. VI); as outras duas medidas previstas para esses mesmos tipos de casos são a "colocação em casa de semi-liberdade" (seção III) e a "internação" (seção IV). No caso do ECA (BRASIL, 1990), enquanto o Capítulo II, do Título II prevê as medidas de proteção, o Título III trata especificamente da prática de ato infracional, incluindo um capítulo próprio, especifico de medidas sócio-educativas, para serem aplicadas a esse tipo de situação. Quer dizer, embora as medidas protetivas e preventivas se destinem a todas as crianças e adolescentes, mesmo quando ocorre a prática infracional, o artigo 112 é claro, "verificada a prática de ato infracional, a autoridade competente poderá aplicar ao adolescente as seguintes medidas: I- advertência; II -obrigação de reparar o dano; III prestação de serviços à comunidade"; IV - liberdade assistida; V -inserção em regime de semiliberdade; VI -internação em estabelecimento educacional; VII -qualquer uma das previstas no art. 101, I a VI".

Segundo concluímos da leitura de ambas as leis, aqui usadas como referência (BRASIL, 1979; BRASIL, 1990), assim como de autores que as estudaram (MACHADO, 1986; NOGUEIRA, 1985 e 1991; ALBERGARIA, 1991), bem como dos processos ditos infracionais relativos aos anos de 1986, 1991 e 1996 (além dos de 1984 e 1985), não há, do nosso ponto de vista, divergências conceituais expressivas entre o que está previsto, como medida, "aplicável ao menor", no Código de Menores (BRASIL, 1979) e o que está previsto, como medida sócio-educativa para o adolescente, no ECA. Em ambos, 
encontramos a advertência, como procedimento inicial, tratando-se num e noutro caso, de uma admoestação verbal, que para nós teria, conforme afirmou MACHADO (1986), "caráter de aviso, de repreensão e de conselho".

Também presente em ambas as leis, estão a liberdade assistida, a semi-liberdade e a internação. Trata-se, no caso da liberdade assistida, de regime ou medida imposta (no Código de Menores, art. 38) (BRASIL, 1979) com "...o fim de vigiar, auxiliar, tratar e orientar o menor", em que "a autoridade fixará as regras de conduta do menor e designará pessoa capacitada ou serviço especializado para acompanhar o caso"; no ECA (BRASIL, 1990), mudam-se os termos, mas a idéia é a mesma, "...com o fim de acompanhar, auxiliar e orientar o adolescente.." (art. 118, ECA), excetuando-se, que, nessa lei, se define as atribuições do orientador; no art. 119 (ECA) se lhe incumbe "I - promover socialmente o adolescente e sua família, fornecendo-lhes orientação e inserindo-os, se necessário, em programa oficial ou comunitário de auxílio e assistência social; II - supervisionar a frequência e o aproveitamento escolar do adolescente, promovendo, inclusive, sua matrícula; III - diligenciar no sentido da profissionalização do adolescente e de sua inserção no mercado de trabalho; IV - apresentar relatório do caso". A despeito de reconhecermos a importância do papel do orientador, na prática, ele depende de condições para a operacionalização dessas tarefas; não há como prescindir da disponibilização de programas oficiais e outros recursos na comunidade, para o encaminhamento do adolescente e sua família, que permitam, ainda que parcialmente, sua "promoção social", sem o risco de cair em mera vigilância dos atos do adolescente, enquanto dura o periodo que se lhe aplicou a medida, ou mera cobrança de adesão pelo adolescente às regras estabelecidas. Do que vimos, nos processos dos anos de 1991 e 1996, posto que em 1986 nenhum caso foi encontrado, trata-se mesmo de um conjunto de regras de conduta, fixadas pela autoridade judiciária, a serem seguidas pelo adolescente, sob acompanhamento de pessoa designada pela mesma autoridade; referem-se, nos casos do ano de 1991, à proibição de frequentar bares e casas de jogos e, de portar armas ou objetos capazes de ofender a integridade física, à obrigatoriedade de matricular-se e frequentar escola, de comprovar em 15 dias o exercício de ocupação lícita, de comparecer mensalmente perante o Juízo, de comprovar periodicamente estar trabalhando; em alguns casos a regra é alternativa, "estar trabalhando ou cursando escola", em outros, essa obrigatoriedade da "comprovação de exercício de ocupação lícita" pelo adolescente, é substituida pela determinação do Juiz ao orientador, 
para que o mesmo "diligencie no sentido da sua profissionalização e inserção no mercado". Nos casos dos anos de 1996, ocorrem duas situações: em alguns casos, as condições dessa liberdade assistida são referidas, mas não explicitadas: "...foi esclarecido as condições da sentença desses autos e foi designado .... para o acompanhamento do caso..", em outros, os termos sequer são referidos. Do nosso ponto de vista, comparativamente às demais medidas, a liberdade assistida pode abrir a interessante possibilidade de uma intervenção diferenciada (voltada para o desenvolvimento da pessoa do adolescente e não para a sua correção punitiva), através da participação de diferentes agentes e da mobilização de recursos de áreas diversas, como a da saúde, da educação, de cultura, entre outras, mas para isso, é preciso que se leve em conta o cumprimento de artigos do ECA, que tratam, entre muitas coisas, das políticas públicas para a proteção da criança e do adolescente.

A semiliberdade, embora esteja nas duas leis, a revogada e a atual, não aparece entre os processos lidos. Segundo compreendemos, trata-se de uma forma intermediária, de permanência em uma "casa de semiliberdade" ou "em regime de semiliberdade" transitoriamente, para o meio aberto, onde o adolescente teria a possibilidade de realizar atividades externas, visando sua escolarização e profissionalização. MACHADO (1986) fala da implantação desse regime em duas unidades da FEBEM-SP, à época em que presidia essa Entidade, explicitando que "...os menores, segundo suas características de personalidade, podiam frequentar escola e o núcleo profissionalizante abertos à comunidade" e que "passavam os fins de semana com suas familias e participavam de uma série de programas de vida comunitária". Quanto à internação não há dúvidas, é a aplicação do regime fechado, vez que implica necessariamente a privação de liberdade; o adolescente é enviado para uma instituição, onde permanece confinado, até que sendo avaliado, a autoridade judiciária decida pelo seu desligamento dessa instituição, ou, conforme explicou NOGUEIRA (1985), pela extinção do motivo em que se fundamentou a medida. No caso do Código de Menores (BRASIL, 1979), a internação está prevista "em estabelecimento educacional, ocupacional, psicopedagógico, hospitalar, psiquiátrico ou outro adequado", no caso do ECA (BRASIL, 1990) "em estabelecimento educacional". Num e noutro caso, o estabelecimento, para o qual se destinam os adolescentes, que recebem essa sentença, é o mesmo, a FEBEM.

A obrigação de reparar o dano e a prestação de serviços à comunidade aparecem no ECA e em alguns dos processos lidos, como se verá adiante. NOGUEIRA (1991), 
contudo, mostra que, no Código de Menores (BRASIL, 1979), essa possibilidade já existia em seu art. 103, que previa, que "sempre que for possível e se for o caso, a autoridade judiciária tentará, em audiência, com a presença do menor, a composição do dano por este causado". O mesmo autor nos esclarece também, acerca da prestação de serviços à comunidade, que essa “...constitui, na esfera penal, pena restritiva de direitos, que consiste na atribuição ao condenado de tarefas gratuitas junto a entidades assistenciais, hospitais, escolas, orfanatos e outros estabelecimentos congêneres, em programas comunitários ou estatais (CP. art.46)."

Partindo desse quadro referencial, que sintetiza parte da fundamentação que nos norteia o entendimento sobre as medidas aplicáveis às situações de natureza dita infracional, passamos a descrever os contingentes encontrados para cada um dos tipos já identificados como infracionais, incluindo nessa descrição o conjunto de medidas respectivamente aplicadas, para cada um desses tipos de situação infracional. 
5.2. Acerca das frequências das situações consideradas infracionais nos anos de 1986, 1991 e 1996.

No ano de 1986, o total de situações categorizadas como infracionais correspondeu a 423 casos. Desse total foram excluídos 6 processos aos quais não tivemos acesso; 1 porque foi remetido a outra Comarca e 5 porque não localizados/encontrados no Arquivo do Fórum. $\mathrm{Na}$ Tabela 7 se apresentam os totais de casos ditos infracionais, encontrados para os três anos de estudo, assim como a frequência dos tipos encontrados em cada um desses anos.

Tabela 7. Natureza e frequência dos casos ditos infracionais registrados no Cartório da Infância e da Juventude de São Carlos, SP, nos anos de 1986, 1991 e $1996^{2}$.

Natureza

Furto

Agressão

Direção de veículo

Droga

Promovendo desordens

Danos

Arma

Roubo

Sexualidade

Estelionato

Ameaça

Outros mal definidos

Álcool

Fuga de casa

Não infracional

Receptação

Homicídio

Suicídio

Ofensas

Desentendimentos

Rua

Total *

*excluidos os processos não localizados no Arquivo do
ou outras Comarcas: 6 de 1986, 7 de 1991 e 8 de 1996.
1986

N. $\%$

10324,8

$47 \quad 11,3$

10525,2

378,9

235,5

$27 \quad 6,5$

133,1

$\begin{array}{ll}3 & \mathbf{0 , 7}\end{array}$

$11 \quad 2,6$

$10 \quad 2,4$

10,2

$\begin{array}{ll}7 & 1,7\end{array}$

$5 \quad 1,2$

$18 \quad 4,3$

20,5

20,5

10,2

20,5

$\begin{array}{lr}- & - \\ - & - \\ 417 & 100,0\end{array}$
1991

N. $\%$

$160 \quad 23,5$

9614,1

15122,2

$20 \quad 2,9$

$49 \quad 7,2$

$39 \quad 5,7$

213,1

9

19

4

23

39

8

11

1,3

2,8

0,6

3,4

5,7

1.2

1.6

$\begin{array}{lr}8 & 1,2 \\ - & -\end{array}$

$3 \quad 0,4$

60,9

40,6

$10 \quad 1,5$

680100,0
1996

N. $\%$

26133,1

12716,1

$115 \quad 14,6$

$51 \quad 6,5$

$47 \quad 6,0$

$39 \quad 4,9$

253,1

$29 \quad 3,7$

$14 \quad 1,8$

9 1,1

$23 \quad 2,9$

$19 \quad 2,4$

50,6

40,5

- $0, \overline{2}$

$9 \quad 1,1$

20,2

$\begin{array}{ll}6 & 0,8\end{array}$

10,1

$788100, \overline{0}$

Dos 417 casos estudados, os percentuais mais elevados, 25,2\% e 24,8, correspondem, respectivamente a 105 casos envolvidos com "direção de veículo" e 103 com a

\footnotetext{
${ }^{2}$ Anexo 31 apresenta o Quadro com todos os tipos descritivos das situações ditas infracionais.
} 
possibilidade de "furto". Os càsos de "direção de veículo" incluem um percentual expressivo de situações com acidente; quase a metade deles, 43,8\%, envolveu algum tipo de acidente e, pelo menos 1 desses resultou caracterizado como homicídio, porque ocasionou a morte da vítima. As medidas encontradas nos processos dessa natureza, foram duas; 10 dos 105 casos foram "arquivados", enquanto os demais 95, ou seja 90,5\% desses casos, receberam "advertência". O setor técnico ${ }^{3}$ do Fórum foi chamado a intervir em 3 desses casos; 2 dos que foram arquivados e 1 dos que recebeu advertência.

Quanto aos casos relacionados com furto, esses incluem 10 casos descritos cum outros possíveis atos infracionais: 1 relativo ao suposto porte ou uso de "arma" e 2 de "droga", 4 à possibilidade de "estelionato" e 3 à possibilidade de "receptação".

Há que se esclarecer, que usaremos dizer "a possibilidade de" e "possiveis" ou "supostos" atos, em algumas situações, porque, em alguns casos, essas situações incluem as "tentativas (de)", assim como as "suspeitas (de)", em outros, porque as medidas adotadas nessas situações revelam que não necessariamente o fato caracteriza o ato, conforme constatamos através da leitura dos processos; por vezes, isto fica explícito nas razões que tantas vezes antecedem ou acompanham essas medidas. Do nosso ponto de vista isso mostra, muitas vezes, que a muitas dessas situações falta suficiente consistência para serem caracterizadas como infracionais.

Em 61,2\% dos casos relacionados com furto, ou seja, 63 deles, a medida adotada foi a aplicação da "advertência"; em 4,9\% (5 casos), a "internação"; em 1,0\% (1 caso), não há informação quanto à medida adotada, mas em 33,0\%, 34 casos, o Juízo decidiu pelo arquivamento do processo. $O$ setor técnico do Fórum foi chamado a intervir (com estudo social ou orientação) em 22 dos 103 casos; nos 5 em que foi aplicada a medida de internação, em 2 dos que foram arquivados e em 15 dos que receberam a advertência.

É importante notar, que nesse ano, mais frequentemente que nos demais, 1991 e 1996, as situações ditas infracionais são acompanhadas pelo setor técnico do Fórum, seja por requisição do Curador, seja por ordem do Juiz. Isso, para nós, sugere um tipo de postura e talvez de concepção, diferente daquele que não se faz acompanhar da intervenção de terceiros; se outros não estão presentes ou não são chamados a opinar, não há como sofrer-

${ }^{3}$ O setor técnico do Fórum constitui-se de uma equipe de profissionais, psicólogos e assistentes sociais, que tem por função assessorar as autoridades judiciárias (juiz ou promotor) no estudo, encaminhamento e atendimento de casos, em que essas autoridades julgam necessária a sua intervenção. 
lhes a influência do ponto de vistà e, muito menos, como instrumentalizar-se mais antes de decidir por um ou outro procedimento ou medida.

Se compararmos as medidas aplicadas numa e noutra das situações, as relativas à "direção de veículo" com as relativas a "furto", veremos que há pelo menos 5 internações nas de furto e nenhuma nas de direção de veículo, nem mesmo no caso que resultou caracterizado como homicídio. Isto nos chama a atenção e faz indagar acerca da gravidade relativa aos diferentes tipos encontrados de situação infracional. Se, além disso, também levarmos em conta e compararmos a frequência com que o setor técnico foi chamado a intervir, a diferença é bastante expressiva; enquanto nas situações de "direção de veículo" o setor técnico interveio em $2,8 \%$ dos casos, nas situações relativas a "furto" ele interveio em $21,3 \%$ dos casos.

Outro dado, que nos põe ainda mais em dúvida, acerca do que é considerado grave ou não, ou mesmo "grave, mas nem tanto", vem através da leitura dos processos, especificamente do conteúdo dos pareceres dos diferentes agentes envolvidos no trato dessas situações, presentes nos respectivos processos. A leitura detida e a comparação desses pareceres deixam a desconfortável impressão de que, enquanto as situações relativas à direção de veículo parecem ser vistas como frequentes, comuns, mas banais, cabendo-lhes, por consequência, rápida, séria, mas simples resolução, as situações relativas a furto parecem ser tomadas como frequentes, comuns, mas problemáticas, pedindo, portanto, medidas mais sérias. Os pareceres se diferenciam mesmo na forma; enquanto os primeiros são curtos e objetivos, os relativos a furto são mais longos, mais detalhados e muitas vezes mais ricos, do ponto de vista da explicitação de algumas concepções desses agentes. Isto foi notado nos processos dos três anos, mas é em 1996 que essa "impressão" encontra maior sustentação, porque se em 1986 e 1991 essas diferenças são sutis, em 1996 elas estão explicitas nesses pareceres.

Esses dados podem sugerir que o furto, enquanto infração, é considerado mais grave que a direção de veículo sem habilitação, a despeito da ocorrência de acidentes. Se assim for, aqui fica uma reflexão: será, de fato a vida, a nossa integridade física, moral ou espiritual o nosso mais valioso bem? Ou serão as nossas posses? Qual o lugar, no nosso cotidiano, da vida e qual o lugar dos nossos bens materiais? Por outro lado, da leitura dos processos restou conosco uma forte impressão, de que a forma de tratar com um e outro tipo de processo sofre os efeitos das prováveis diferentes posições econômico-sociais ocupadas 
pelos adolescentes que se envolvem em furtos, em relação àquelas ocupadas pelos adolescentes envolvidos com direção sem habilitação. Constatamos que o veículo utilizado pelo adolescente era na maioria expressiva dos casos da própria família, o que nos leva a pensar nas ditas diferenças sociais em relação aos que furtam coisas tais como roupas, bonés, bicicletas, etc. Além disso, não foram poucas as vezes que encontramos a designação "desocupado", entre outros, para adolescentes envolvidos com furto, em relação àquelas em que encontramos a designação "estudante", para definir a ocupação dos adolescentes envolvidos com direção sem habilitação; muitos dos casos estudados, embora em idade escolar, de acordo com os registros, não estavam frequentando escola, outro indicador importante da condição social desses adolescentes.

Seguindo com a frequência das situaç̃es ditas infracionais, do ano de 1986, vamos encontrar as relativas à possibilidade de agressão, em terceiro lugar; seus contingentes representam $11,3 \%$ do total dessas situaç̃es. São 47 casos, entre os quais 1 caso associado a suposto porte ou uso de arma. As medidas aplicadas pelo Judiciário, para esses casos foi arquivar 57,4\% deles (27 casos) e dar advertência outros 20 (42,6\%), dos quais apenas 1 recebeu estudo e acompanhamento pelo setor técnico. Se compararmos os percentuais relativos à possibilidade de agressão, com os dos anos de 1991 e 1996, veremos um aumento dos $11,3 \%$, de 1986 , para $14,1 \%$ e $16,1 \%$ dos respectivos totais de situações ditas infracionais desses anos.

No ano de 1991 as situações ditas infracionais totalizaram 687 casos, 7 dos quais foram excluídos, 3 por terem sido remetidos a outro Cartório ou outras Comarcas e 4 por não terem sido localizados no Arquivo do Fórum.

Os percentuais mais expressivos de 1991 são os relativos à possibilidade de furto, $23,5 \%$ (160 casos) do total das situações ditas infracionais desse ano, seguidos dos das situações relativas à direção de veículo, $22,2 \%$ (151 casos). Nota-se, em relação a 1986 , um decréscimo nesses percentuais, que eram $24,8 \%$ e $25,2 \%$, respectivamente, de furto e de direção. Mas, semelhantemente ao que ocorre em 1986, representam juntos quase a metade do total das situações ditas infracionais de 1991. Ou seja, em 1986 e 1991, em aproximadamente a metade das situaçðes entendidas como infracionais, a referência, da dita infração, está na possibilidade de furto e direção de veículo sem habilitação. Dos casos relativos à possibilidade de furto do ano de 1991, 4 aparecem relacionados à possibilidade de agressão e 3 à de estelionato. As medidas aplicadas nesse ano, para os 160 casos relativos 
à possibilidade de furto, incluíram pelo menos 30 casos, representados pelo Promotor de Justiça; ou seja, o Ministério Público ofereceu representação ${ }^{4}$ contra $18,8 \%$ dos adolescentes envolvidos nessas situações. Do total de 160, 5 casos foram apensados a outro(s) processo(s) em andamento (2 precedidos de representação), 66 foram arquivados (4 precedidos de representação), 13 receberam advertência ( 12 precedidos de representação), 6 liberdade assistida (todos precedidos de representação), 1 advertência e liberdade assistida (precedido de representação), 59 remissão ${ }^{5}$ (2 precedidos de representação e seguidos de acompanhamento pelo setor técnico e obrigação de matrícula e frequência em escola e 1 seguido de obrigação de matrícula e frequência em escola), 4 remissão e advertência, 1 busca e apreensão (precedido de representação), 3 internação ( 2 precedidos de representação), e 2 abrigo e acompanhamento pelo setor técnico (1 precedido de estudo social e finalizado com internação; o outro finalizado com arquivamento).

Os 151 casos relativos à direção de veículo, no ano de $1991,22,2 \%$ do total das situações ditas infracionais desse ano, incluem 12 casos envolvidos com acidente. Em 6, desses 151 casos, o Ministério Público ofereceu representação; ou seja, em torno de 4,0\% dos adolescentes envolvidos com situações relacionadas à direção de veículo sofreram representação. Do total de 151 casos, 55 foram arquivados, 83 receberam remissão (2 precedidos de representação), 8 remissão e advertência, 1 remissão, advertência e reparação de danos, 4 advertência (os 4 precedidos de representação).

Quanto aos casos relativos à possibilidade de agressão, no ano de 1991, que são 96, ou seja, 14,1\% do total das situações ditas infracionais desse ano, incluem 6 casos descritos com outros supostos atos infracionais: 1 relativo à possibilidade de porte ou uso de arma, 3 à possibilidade de danos e 2 à possibilidade de lesão corporal seguida de morte. Desses 96,53 casos foram arquivados (1 precedido de estudo social), 2 foram apensados a outro(s) processo(s) em curso, 34 receberam remissão ( 1 precedido de representação, 1 com medida de obrigação de matrícula e frequência em escola), 2 remissão e advertência, 4 liberdade

\footnotetext{
${ }^{4}$ A Representação, procedimento previsto no art. 182, do ECA, é "...oferecida por petição, que conterá o breve resumo dos fatos e a classificação do ato infracional e, quando necessário, o rol de testemunhas..."; tratase, neste estudo, de petiçăo feita pelo Ministério Público (promotor) à autoridade judiciária (juiz) requerendo a aplicação de medida ao adolescente, por prática, em tese, de ato infracional.

${ }^{5}$ Remissão não é termo de fácil explicaçăo; embora a consulta aos dicionários nos permita entendê-lo como perdato ou açao ou efeito de remitir, o que significa indultar, perdoar, essa idéia se aplica para os casos em que apenas a remissão é concedida, sem aplicação de outra medida cumulada, tal como ocorre nos casos de remissão cumulada com liberdade assistida ou, com prestação de serviços à comunidade ou ainda, com advertência. Mais adiante nos deteremos para comentá-lo a partir da leitura de autores da área jurídica.
} 
assistida (os 4 antecedidos de representação) e 1 advertência (precedido de estudo social). No total de casos, enquanto o setor técnico foi chamado a intervir em apenas 2 casos, o Ministério Público ofereceu 5 representações, ou seja, representou contra o adolescente em $5,2 \%$ dos casos de possibilidade de agressão.

Em 1996, as situações ditas infracionais correspondem a 796 casos; excluídos 8 casos, 4 que não foram localizados no Arquivo do Fórum e 4 que foram remetidos a outro Cartório ou outras Comarcas, esse total caiu para 788.

Nesse ano o percentual mais expressivo é o das situações relacionadas à possibilidade de furto, que representam $33,1 \%$ do total das situações ditas infracionais desse mesmo ano. Considerando os percentuais dos anos anteriores, nota-se que a frequência dos casos relacionados à possibilidade de furto, inicialmente diminui, dos $24,8 \%$ das situações ditas infracionais de 1986 , para os $23,5 \%$ das de 1991 , aumentando daí para os $33,1 \%$ das de 1996. As situações relativas à possibilidade de furto, também em 1996, incluem casos em que o furto aparece associado a outros supostos atos infracionais. São 10 dos 261 casos, 4 relacionados à possibilidade de uso ou tráfico de droga, 4 à de danos, 1 à de ameaça e 1 à de agressão. Quais as respostas dadas pelo Judiciário nessas situações? Dos 261 casos, 52 foram arquivados (10 precedidos de representação e 1 de estudo social), 2 foram para internação (ambos antecedidos de representação), 1 recebeu advertência, 1 foi encaminhado ao Conselho Tutelar, 126 receberam remissão ( 58 precedidos de representação), 23 remissão e advertência (4 precedidos de representação), 28 remissão e prestação de serviços à comunidade (4 precedidos de representação), 23 remissão e liberdade assistida (18 precedidos de representação), 4 liberdade assistida (todos antecedidos de representação) e 1 absolvição ${ }^{6}$ (também precedido de representação). Chamam-nos a atenção, o percentual de representações aí oferecidas, 46,4\%; ou seja, 121 casos contra os quais o Ministério Público representou e o número de casos em que o setor técnico foi chamado a intervir, que se limitou a 1 caso.

O $2^{\circ}$ e $3^{\circ}$ percentuais mais expressivos, das 788 situações ditas infracionais do ano de 1996, são muito próximos e representam respectivamente $16,1 \%$ e $14,6 \%$ desse total de situações. Os $16,1 \%$ correspondem a 127 casos relacionados com agressão; os $14,6 \%$ a 115 casos relativos à direção de veículo sem habilitação.

\footnotetext{
${ }^{6} \mathrm{O}$ termo absolvição aparece na sentença final, não se constituindo "medida" propriamente dita, como as demais medidas previstas pelo ECA. Aparece exclusivamente nesse ano, 1996 e, exclusivamente em 4 casos.
} 
As situações relacionadas com a possibilidade de agressão incluem 1 caso associado com a possibilidade de danos e $1 \mathrm{com}$ a de promover desordens. Quanto às medidas aplicadas, 23, dos 127 casos relacionados com a possibilidade de agressão, foram arquivados, 67 receberam remissão (4 precedidos de representação e 1 seguido de orientação, apoio e acompanhamento pelo setor técnico), 32 remissão e advertência, 3 remissão e prestação de serviços à comunidade (os 3 precedidos de representação), 1 foi apensado a outro processo em curso e 1 foi encaminhado ao Conselho Tutelar. $O$ setor técnico foi chamado a intervir num único caso e o número total de casos contra os quais o Ministério Público ofereceu representação foi 7 , que corresponde a 5,5\% dos 127 casos relativos à agressão.

Somados os dois percentuais mais expressivos de 1996, ou seja, 33,1\% e 16,1\%, teremos quase $50,0 \%$ das situações entendidas como infracionais, cuja referência infracional, está na possibilidade de furto e de agressão. No anos anteriores, 1986 e 1991, a referência da infração para os mesmos quase $50 \%$ do total de situações ditas infracionais desses anos, está na possibilidade de furto e direção de veículo. São mudanças a serem observadas.

Para nós, não é sem razão que, ao levantar a natureza das situações ditas infracionais, tenhamos deparado com o furto, não apenas como um dos três mais frequentes tipos de situação (furto, direção, agressão) nos 3 anos de estudo, 1986, 1991 e 1996, mas como o tipo mais frequente, em 1991 e 1996. Isso nos fez pensar, nas vezes que ouvimos dizer dos nossos "perigosos", "criminosos" "menores"... ...e ficamos tentando entender que "crime" era esse, o de apropriar-se do que "pertence ao outro". Se considerarmos que o furto está descrito como a posse da coisa alheia, o "subtrair para si ou para outrem, coisa alheia móvel" (art.155, Código Penal, BRASIL, 1940) e levarmos em conta que a posse não é condenada, senão porque a coisa pertence ao outro, que o "crime" ou "infração penal" está em atingir o legalmente denominado "patrimônio" do outro, talvez coubesse indagar o por quê do furto. Talvez devêssemos saber dos adolescentes que se envolveram em furtos, o que buscavam e por que "tomar do outro" quando, afinal, se pode adquirir "licitamente"... ...se pode mesmo?

O furto, resultado da ação de adolescentes, é para nós um indicador da situação de privação de bens materiais por eles vivida no seu cotidiano. Por isso, nos parece pertinente indagar, se não nos temos equivocado, tratando da situação exclusivamente do ponto da 
aplicação do julgamento, da autoria e da prova, da infração ou crime e portanto, da necessidade da aplicação ou não da "devida" punição. Se levarmos em conta o tipo de "coisa furtada" e revelarmos o quanto foi comum encontrar entre os objetos de furto, coisas de valor monetário irrisório, do ponto de vista da sua relação com os custos da mobilização do aparato judicial, para o seu "julgamento", essa indagação ganha ainda mais pertinência (...o mais comum, foram os de menor valor, como shampoo, barras de chocolate, laranjas, boné, garrafas, camisetas, roupas, calça, etc, seguidos de outros de maior valor, como relógio, tape, bicicleta; raramente os de muito maior valor, como carro....).

Da leitura dos processos, acabamos constatando não apenas que eram frequentes os furtos de objetos/coisas de pequeno ou muito pouco valor monetário, mas que o tratamento pelo Juizo era o mesmo, independendo do valor da coisa; assim, pudemos também perceber que era falso o nosso pressuposto de que os objetos, produtos de furto, seriam coisas/objetos valiosos do ponto de vista material, pois aquilo de ser coisa de pouco valor era o que ocorria na maioria daqueles furtos.

Assim, se além de observarmos os produtos de furto, encontrados nos processos aqui estudados, levarmos também em conta que o furto é, não apenas o tipo mais frequente de situação, entre as ditas infracionais, tanto do ano de 1991 como de 1996, mas que essa frequência tem aumentado nos últimos anos (de $24.8 \%$ e $23.5 \%$ em 1986 e 1991 , respectivamente, para $33.1 \%$ em 1996), poderiamos nos indagar: "não será a "fome de bens", própria da desigualdade econômica e dos apelos consumistas, dos modelos econômicos por nós adotados, uma boa "hipótese explicativa" para esses "comportamentos"? Será que quem "furtou", tinha como "comprar"? Será que furtaria, se tivesse? Alguns de nós provavelmente nos diriam: "_se não tem, porque não pede?" ou "_por que não trabalha?" Parece-nos, que não apenas condenamos o furto, mas condenamos o sujeito que o "prefere" à possibilidade de mendigar ou de trabalhar. Seria interessante nos indagar a respeito; quem de nós gostaria de se submeter à humilhação de "pedir"? ou se submeteria à qualquer espécie de tarefa $\mathrm{e}$, mais, a vender sua força de trabalho pelos "salários" miseráveis que oferecemos? Além disso, para quem se detém a olhar, é fácil ver que começam mesmo "pedindo", pequenas, mas inevitavelmente, crescem... adolescem... e aí fica difícil entender, por que o outro tem, e ele, não? Algum de nós é capaz de responder?

Quanto às situações relativas à direção de veículo, do ano de 1996, que somam 115 casos, incluem-se 1 caso associado à possibilidade de ameaça, 2 à de furto e 24 à de 
acidente. As medidas aplicadas para esses casos foram: o arquivamento de 16 casos, a remissão para 87 casos e para os demais 12 casos, a remissão e advertência. Nenhuma representação foi aí oferecida pelo Ministério Público. E o setor técnico não foi chamado a intervir em nenhum desses casos.

Além das situações relativas à possibilidade de furto, de direção de veículo sem habilitação e de agressão, que constituem os principais percentuais nos 3 anos de estudo, temos percentuais menos expressivos, mas igualmente importantes, que se referem aos demais tipos descritos no conjunto das situações ditas infracionais.

Tomando por base a ordem decrescente das frequências encontradas para os diferentes tipos de situações ditas infracionais, conforme apresentadas na Tabela 7 , passamos a descrever os percentuais encontrados para os demais tipos encontrados, cujos valores, diferentemente dos relacionados a furto, à direção de veículo e à agressão, que variam de $11,3 \%$ a $33,1 \%$, para os 3 anos estudados, apresentam valores inferiores, que variam entre $8,9 \%$ e $0,1 \%$.

O percentual de casos relacionados com a possibilidade de uso, porte ou tráfico de droga, foi de $8,9 \%$ em $1986,4^{\circ}$ mais expressivo desse ano. Corresponde a 37 casos, dos quais 17 foram arquivados ( 1 deles precedido de estudo social) e 20 receberam advertência ( 7 deles com estudo social ou orientação). O setor técnico interveio, portanto, em 8 casos, ou seja, em 21,6\% dos casos relacionados com droga.

Já em 1991, o percentual desses casos, em relação ao total de situações ditas infracionais desse ano, é de apenas 2,9\%, ou seja 20 dos 680 casos. Desses 20, 13 casos foram arquivados ( 3 precedidos de representação), 1 recebeu advertência (antecedida de representação), 3 remissão e orientação, apoio e acompanhamento do setor técnico e inclusão em programa de tratamento, 2 liberdade assistida (precedidos de representação) e 1 foi apensado a outro(s) processo(s) em curso. O setor técnico foi chamado a intervir em 3 (15\%) dos casos total, enquanto o Ministério Público ofereceu representação contra 6 (30\%) dos casos.

Em 1996 esses casos representam 6.5\% do total de situações ditas infracionais do ano, ou seja 51 , dos 788 casos. É, como em 1986, o $4^{\circ}$ percentual mais expressivo dessas situações. Dos 51 casos, 10 foram arquivados ( 2 precedidos de representação), 1 recebeu advertência (antecedida de representação), 13 remissão (1 seguido de orientação, apoio e acompanhamento do Conselho Tutelar), 23 remissão e advertência (1 precedido de 
representação), 1 remissão e prestação de serviços à comunidade (precedido de representação), 2 liberdade assistida (ambos precedidos de representação) e 1 absolvição (?) (precedido de representação). Enquanto o setor técnico não foi chamado a intervir em nenhum caso, o Ministério Público representou contra 8 casos $(15,7 \%)$.

As situações relativas à possibilidade de danos aparecem em $5^{\circ}$ lugar entre os casos ditos infracionais de 1986. São 27, ou 6,5\%, dos 417 casos desse ano. As medidas aí aplicadas pelo Judiciário foram o arquivamento de 12 desses casos e a aplicação de advertência para os demais 15 casos ( 2 deles seguidos de estudo social). Aqui, portanto, o setor técnico foi chamado a intervir em pelo menos 2 casos, entre os 15 que foram advertidos.

No ano de 1991, a possibilidade de danos ocupa o 6o. lugar entre os percentuais de situações ditas infracionais. São 39 casos, que representam 5,7\% do total de 680 casos a que correspondem essas situações. Quanto às medidas aplicadas encontramos 1 caso apensado a outro(s) processo(s) em curso e, pelo menos 1 caso encaminhado a programa (antecedido de estudo social); 14 casos receberam remissão, 2 remissão e advertência, 4 advertência ( os 4 precedidos de representação) e 17 foram arquivados (2 deles precedidos de estudo social). Tivemos, portanto, a intervenção do setor técnico em 2 casos e um total de 4 representações pelo Ministério Público.

No ano de 1996 tivemos o mesmo total de 39 casos relacionados à possibilidade de danos, de 1991, representando, contudo, um percentual inferior, de $4,9 \%$ do total dos casos relativos às situações ditas infracionais de 1996. Nos casos desse ano, o Judiciário decidiu pelo arquivamento de 15 casos, deu remissão a 16 casos, a outros 3 remissão e advertência, a 2 remissão e prestação de serviços à comunidade, a 2 remissão, prestação de serviços à comunidade e reparação de danos e a 1 remissão e orientação, apoio e acompanhamento pelo Conselho Tutelar.

As situações relativas à possibilidade de promover desordens figuram em $6^{\circ}$ lugar na ordem dos percentuais mais expressivos das situações dita infracionais do ano de 1986, em $4^{\circ}$, no ano de 1991 e em $5^{\circ}$ no de 1996. Em 1986 são 5,5\% do total das situações ditas infracionais desse ano, ou 23 casos, dos quais 14 receberam advertência e 9 foram arquivados ( 1 precedido de estudo social). Em 1991 são 49 casos, ou 7,2\% do total das situações ditas infracionais do referido ano, 3 dos quais aparecem associados a outros supostos atos infracionais: 1 relativo a danos e 2 relativos à droga. As medidas aplicadas 
foram o arquivamento, para 21 dos casos e a remissão, para os demais 28 casos. Em 1996 são 47 casos, que representam 6,0\% do total das situações ditas infracionais desse ano. Desses, 2 casos estão associados a outras possibilidades de infração: 1 descrito como relativo a desacato e o outro a danos. Pelo menos 1 dos 47 casos foi apensado a outro(s) processo(s) em curso, 28 receberam remissão, 8 remissão e advertência, 4 remissão e prestação de serviços à comunidade e 6 foram arquivados. Comparado aos anteriores, o ano de 1996 envolveu maior número de medidas. Parece haver diferentes entendimentos nos três anos relativamente à importância desse tipo situação.

Os casos relacionados à possibilidade de porte ou uso de arma ocupam o $7^{\circ}$ lugar das frequências mais expressivas das situações ditas infracionais de 1986. Representam 3,1\% do total dessas situações ou 13 casos. Exceto por 1 caso que foi arquivado, todos os 12 restantes receberam advertência. Em 1991, embora o número desses casos seja 21, eles representam os mesmos percentuais de 1986, ou seja 3,1\% do total de situações ditas infracionais desse ano, ocupando igualmente o $7^{\circ}$ lugar de suas frequências mais expressivas. Nesse ano, as medidas aplicadas foram a remissão para 10 casos, a remissão e advertência para 2 casos e o arquivamento para 9 casos. Quanto ao ano de 1996, os percentuais desses casos também representam 3,1\% do total das situações ditas infracionais desse ano, que correspondem a 25 casos, 2 dos quais associados à possibilidade de desacato. Desse total de 25 casos, 3 foram arquivados, 17 receberam remissão e 5 remissão e advertência.

Os casos relacionados à possibilidade de ações relativas à sexualidade aparecem em $8^{\circ}$ lugar entre as frequências das situações ditas infracionais de 1986 e em 10o. lugar tanto no ano de 1991, como no de 1996. Representam 2,6\% daquelas situações em 1986, que correspondem a 11 casos. Quase todos, 9 casos, receberam como medida a aplicação de advertência. Embora nos outros 2 casos o Judiciário tenha determinado o arquivamento, os registros incluem que naquela "...oportunidade os menores foram advertidos e orientados".

Em 1991, são percentualmente pouco mais expressivos que em 1986; representam 2,8\% das situações ditas infracionais de 1991, que correspondem a 19 casos. Desses, 3 aparecem associados à outras possibilidades de infração: 1 de agressão e 2 de roubo. A maioria desses casos, 14, foi arquivada, 3 dos quais precedidos de representação. Dos demais, 2 receberam remissão, 1 remissão e advertência (precedida de representação), 1 advertência e 1 liberdade assistida (ambos precedidos de representação). O Ministério 
Público representou, portanto, contra mais de 30,0\% desses casos. Em 1996 os percentuais dos casos relativos à sexualidade representam $1,8 \%$ do total das situações ditas infracionais desse ano e correspondem a 14 casos. A metade deles, 7 casos, foram arquivados, 3 receberam remissão ( 1 precedido de representação), 3 remissão e advertência e 1 remissão e prestação de serviços à comunidade (precedido de representação). Nesse ano, portanto, o percentual de representações oferecidas pelo Ministério Público foi inferior àquele de 1991, ocorrendo em torno de $14,0 \%$ dos casos dessa natureza desse mesmo ano.

As situaçôes relativas à possibilidade de estelionato aparecem, no ano de 1986 , em $9^{\circ}$ lugar entre as frequências das situações ditas infracionais desse ano. São 10 casos, que representam 2,4\% do total dessas situações. Em 1991 são 4 os casos dessa natureza e representam apenas $0,6 \%$ do total das situações ditas infracionais desse ano. Em 1996 são um pouco mais expressivas, representando $1,1 \%$ das situações ditas infracionais do mesmo ano, os quais correspondem a 9 casos. Quanto às medidas aplicadas, em 1986, o Judiciário deu a 9 dos 10 casos, a medida de advertência e arquivou 1 caso. Em 1991, deu a remissão a 2 dos 4 casos e remissão cumulada com advertência aos outros 2 casos, não ocorrendo, portanto, nenhum caso de representação do Ministério Público. Em 1996 o Juízo arquivou 1 dos 9 casos, deu remissão a 5 outros e remissão e advertência a 3 casos, 2 dos quais precedidos de representação. Embora sejam apenas 2, esses casos representam $22,2 \%$ do total relacionado à possibilidade de estelionato desse ano.

As situações ditas infracionais incluem um percentual de situações relacionadas a outras possibilidades mal-definidas. Em 1986 há 7 desses casos, os quais representam 1,7\% do total dessas situações nesse ano. Em 1991, são bem mais expressivas, totalizando 39 casos, que representam $5,7 \%$ do total das situações ditas infracionais, ocupando o $5^{\circ}$ lugar na ordem das frequências mais expressivas desse ano. Em 1996, esses percentuais caem para 2,4\% do total das situaçס̃es ditas infracionais desse ano, os quais correspondem a 19 casos. Relativamente às medidas aplicadas, 4 dos 7 casos de 1986, receberam advertência ( 1 precedido de estudo social) e 3 foram arquivados. Em 11 dos 39 casos de 1991, foi concedida a remissão, em outros 27 foi determinado o arquivamento; em 1 outro o Juízo decidiu pelo recambiamento da criança/adolescente à Comarca de origem e o arquivamento dos autos. Em 1996, o Juízo deu a remissão a 12, dos 19 casos ditos infracionais, maldefinidos desse ano, decidiu pelo arquivamento de outros 6 e pelo apensamento de 1 , a outro(s) processo(s) em curso. 
Na sequência das frequências das situações ditas infracionais do ano de 1986, vamos encontrar percentuais de $1,2 \%$ de situações relacionadas à possibilidades de ingestão de álcool, os quais correspondem a 5 dos casos desse ano. Em 1991, eles somam 8 casos, sendo 1 deles associado à possibilidade de uso ou porte de arma; esses 8 casos representam $1,2 \%$ do total de situações ditas infracionais do mesmo ano. Em 1996 esses percentuais caem para $0,6 \%$ do total dessas situações nesse ano, correspondendo a 5 dos casos desse mesmo ano. A medida aplicada no ano de 1986 foi a advertência para os 5 casos; no ano de 1991, 6 dos 8 casos foram arquivados, 1 caso recebeu remissão e 1 último foi apensado a outro(s) processo(s) em curso; em 1996 os 5 casos foram arquivados.

As situações relacionadas à possibilidade de roubo representam $0,7 \%$ das situações ditas infracionais de 1986 e correspondem a 3 casos. Em 1991 são 9 casos, que representam 1,3\% do total das situações ditas infracionais desse ano. Em 1996 esses casos são mais expressivos; são 29 casos, entre os quais 1 associado à possibilidade de formação de quadrilha, que representam 3,7\% das situações ditas infracionais do mesmo ano e ocupam a $7^{\mathrm{a}}$ posição na ordem das frequências dessas situações.

Relativamente às medidas, em 1986, o Juízo determinou o arquivamento dos 3 casos ( 1 deles foi precedido de estudo social); em 1991, foi aplicada a advertência em 6 casos, a liberdade assistida em 2 (todos os 8 antecedidos de representação) e em 1 caso foi determinada a internação. Considerando que 8 casos representam $88,8 \%$ dos 9 dessa natureza nesse ano, temos aí o maior percentual de casos contra os quais o Ministério Público ofereceu representação, do ano de 1991. Em 1996, 4 dos 29 casos receberam remissão (3 precedidos de representação), 2 absolvição (precedidos de representação), 5 remissão e liberdade assistida (4 precedidos de representação), 2 remissão e advertência (ambos antecedidos de representação), 2 liberdade assistida (também precedidos de representação), 12 arquivamento (1 precedido de representação) e 2 internação (também precedidos de representação. Novamente o percentual de representações chamam-nos a atenção. O Ministério Público representou contra 55,2\% dos casos relacionados com a possibilidade de roubo do ano de 1996.

Os demais tipos de situações ditas infracionais do ano de 1986, representam, cada um, $0,5 \%$ e $0,2 \%$ do total das situações ditas infracionais desse ano e correspondem respectivamente a 2 e 1 casos. São 2 casos correspondentes às situações relacionadas à possibilidade de homicídio, 2 casos às relacionadas à possibilidade de receptação e mais 2 
às relacionadas com a possibilidade de ofensa. Com 1 caso cada comparecem as situações relacionadas à possibilidade de ameaça e as relacionadas à possibilidade de suicídio. Nesse ano, a medida aplicada nas situações relacionadas à possibilidade de homicídio foi a internação, nos 2 casos. Nas relacionadas à possibilidade de receptação foi a advertência, igualmente para os 2 casos. A medida de advertência foi também a determinada para os 2 casos relacionados à possibilidade de ofensa.

No ano de 1991, as situações relacionadas à possibilidade de homicídio apresentam percentuais de $0,4 \%$, a menor das frequências das situações ditas infracionais desse ano; correspondem a 3 casos, do total dessas situações, percentualmente inferiores, portanto, aos $0,5 \%$ de 1986. Em 1996, esses percentuais aumentam para 1,1\%, correspondentes a 9 casos, sendo 1 deles associado à possibilidade de agressão. As medidas aplicadas em 1991, para esses casos, foram a internação, para 1 deles e a liberdade assistida, para os outros 2 casos. Todos os 3 foram precedidos de representação pelo Ministério Público.

No ano de 1996, o Ministério Público representou contra 8 dos 9 casos relacionados à possibilidade de homicídio, desse ano: em 4 deles o Juízo determinou a internação, em 1 liberdade assistida e prestação de serviços à comunidade, em 2 liberdade assistida e em 1 remissão; o arquivamento foi determinado num único caso não representado.

Quanto às situações relacionadas à possibilidade de receptação, não há registro de nenhum caso, entre as situações ditas infracionais do ano de 1991. Em 1996, há 2 desses casos, que representam $0,2 \%$ das situações ditas infracionais desse ano. Em 1 dos casos o Juízo determinou o arquivamento, no outro deu a remissão.

Os casos correspondentes às situações relacionadas à possibilidade de ofensa, $2 \mathrm{em}$ 1986, 6 em 1991 e 6 em 1996, representam respectivamente $0,5 \%, 0,9 \%$ e $0,8 \%$ do total das situações ditas infracionais de cada um desses anos. Dos 6 casos de 1996, 1 estava associado à possibilidade de agressão. Quanto às medidas, o Juízo determinou, em 1986, a aplicação de advertência para os 2 casos e em 1991, o arquivamento dos 6 casos; em 1996, 5 casos receberam remissão e 1 remissão e advertência.

As situações relacionadas à possibilidade de ameaça são mais expressivas em 1991; enquanto em 1986 elas não ultrapassam os $0,2 \%$ do total das situações ditas infracionais desse ano, em 1991 sua frequência alcança 3,4\% do total das situações ditas infracionais do mesmo ano, correspondentes a 23 casos; 5, desses 23 casos, estão associados à outras possibilidades de infração: 3 à de agressão e 2 à de desordens. Em 1996, apesar do mesmo 
número de casos, 23, esses percentuais são menores, representando $2,9 \%$ do total das situações ditas infracionais de 1996; esses 23 casos também incluem alguns associados à outras possibilidades de infração: 1 à de desacato, 3 à de agressão e 8 à de danos. Com relação às medidas, no ano de 1986, o Juízo decidiu pelo arquivamento do caso. Em 1991, deu a remissão a 10 casos ( 1 antecedido de estudo social) e a 1 , remissão e advertência; 1 caso foi apensado a outro(s) processo(s) em curso e 11 foram arquivados. No ano de 1996, 14 casos receberam remissão, 3 remissão e advertência, 2 remissão e liberdade assistida e 4 arquivamento.

Há ainda casos relacionados à possibilidade de suicídio, que aparecem em 1986 e também em 1996; em 1991 não foram encontrados registros desse tipo de caso. Representam, igualmente, 0,2\% do total das situações ditas infracionais de 1986 e de $1996 \mathrm{e}$ correspondem respectivamente a 1 e 2 casos. Em todos os casos a medida adotada foi o arquivamento. $\dot{E}$ importante destacar que, antes do arquivamento ser determinado no caso de 1986, foi requerido pelo Ministério Público seu encaminhamento para acompanhamento pelo Conselho Tutelar; mediante a informação do Cartório de que a adolescente envolvida se havia mudado para outra cidade, foi requerido o arquivamento do processo.

Conforme colocamos ao início da descrição da natureza das situações infracionais, adotamos o uso de termos como "a possibilidade de" e "possíveis" ou "supostos" atos, em algumas situações, porque, em alguns casos, essas situações incluem as "tentativas (de)", assim como as "suspeitas (de)", em outros, porque as medidas adotadas nessas situações revelam que não necessariamente o fato caracteriza o ato, conforme constatamos através da leitura dos processos; como em outros casos, esses suicídios, não são atos consumados ou conforme estabelece o artigo 14 do Código Penal (BRASIL, 1940) não configuram o "crime consumado" (art. 14, inc. I), mas sim "tentado", razão pela qual configura-se como "tentativa" (art 14, inc. II ).

As situações ditas infracionais de 1986, incluem 18 casos, que a despeito do registro como sindicância, não se caracterizam como infracionais, tendo sido conduzidos por procedimentos comuns a situações protetivas (como abrigo, desabrigo, entrega e advertência à família, destituição de pátrio poder, etc, acompanhados de estudo social) e não pela aplicação de medidas típicas dos processos tidos como infracionais, aqui já descritas. Em 1991, encontramos 8 outros casos, 7 relacionados com mendicância e 1 com fuga de casa, mas registrados como pedido de providência e não como apuração de ato infracional, 
segundo inferimos porque o Boletim de Ocorrência que acompanha os registros desses casos, não provêm da autoridade policial, mas sim do Poder Judiciário, representado pelo Comissário de Menor. Nos processos estudados de 1996 não encontramos registros desse tipo.

Além dos tipos de situações ditas infracionais até aqui descritos, com suas respectivas frequências, encontramos 3 outros que não aparecem no ano de 1986; 1 dos tipos, que só aparece em 1991, é o relativo à possibilidade da infração estar no perambular ou mendigar pela rua, tipo semelhante ao dos 7 casos acima referidos, relacionados com mendicância, distintos, porém, porque autuados como apuração de ato infracional. São 10 os casos desse tipo e representam 1,5\% do total de situações ditas infracionais de 1991. Em 8 desses casos, a criança/adolescente foi recambiada para a comarca de origem e o processo arquivado; 2 casos foram arquivados, 1 dos quais precedido de estudo e acompanhamento pelo setor técnico do Fórum.

Os outros 2 tipos são relativos à possibilidade de desentendimentos e à possibilidade de fuga de casa; aparecem tanto em 1991, quanto em 1996. Foram 4 os casos relacionados à possibilidade de desentendimentos encontrados no ano de 1991, 0,6\% do total das situações ditas infracionais desse ano e apenas 1 caso em 1996. O Juízo, em 1991, determinou o arquivamento desses 4 casos; em 1996 deu ao único caso a remissão. Aqueles relacionados à possibilidade de fuga de casa somam 11 casos em 1991, 1,6\% do total das situações ditas infracionais desse ano e 4 casos em 1996, 0,5\% das situações ditas infracionais do mesmo ano. Com relação às medidas, em 1991, o Juízo deu remissão a 1 caso, a 7 arquivou e a outros 3 determinou o recambiamento da criança/adolescente envolvido à comarca de origem e o arquivamento do respectivo processo. Em 1996, 2 casos foram arquivados e 2 foram encaminhados ao Conselho Tutelar.

Diante desses dados, nossas impressões iniciais se confirmam; parece, primeiro, não haver relação entre o tipo de situação infracional e o tipo de medida nela aplicado, exceto para os casos de homicídio e furto, em que parece haver razões para a internação; segundo, parece também não haver diferenças essenciais, entre os anos estudados, 1986, 1991 e 1996, no que diz respeito ao tratamento das situações ditas infracionais, pelo Judiciário, a despeito da mudança da legislação em 1990, qual seja, a instituição do ECA e a revogação do Código de Menores. 
A nós parece que isso está relacionado com o que ocorre com a própria legislação; a despeito de artigos que sinalizam para uma concepção mais abrangente, presentes no ECA (Brasil, 1990), essas mudanças conceituais, contidas prioritariamente em seu Livro I (que tratam de uma nova proposta de abordagem do objeto dessa lei, a criança e o adolescente, enquanto sujeitos de múltiplos direitos _descritos nesse mesmo Livro, e enquanto pessoas em condição peculiar de desenvolvimento), não alcançam as proposições do Livro II, que tratam, entre outros, da aplicação de medidas, para a criança e o adolescente, cuja conduta foi traduzida por infracional, com base na mesma referência anteriormente utilizada, de natureza penal. Apesar de propor proteção integral, mantém o pressuposto da punição como parte dessa proteção; provavelmente isso se baseia, entre outros, na crença de que quem ama protege, portanto corrige, inclusive punindo. Resulta que as respostas para alguns comportamentos dessas crianças e adolescentes continuam sendo as mesmas; condutas antes tomadas isoladamente como criminosas, por infração ao código penal, continuam sendo tomadas da mesma forma, como crime ou contravenção penal. $\dot{A}$ semelhança do que antes "cabia", continua a prática de reduzir o sujeito da conduta, o "menor", de antes, ou a "criança ou adolescente", de hoje, à condição de "criminoso" ou, como preferem alguns, de "infrator", a despeito da aceitação formal como legítima, de suas demais características, que o identificam como "pessoa" em "condição peculiar de desenvolvimento".

Assim, não surpreende que as respostas continuem se limitando à aplicação de medidas, centradas em sua própria conduta. Talvez, também por isso, nossas impressões acerca das medidas aplicadas nessas situações, nos façam crer que elas sejam inócuas, se não negativas, não promovendo os comportamentos esperados; parecem não produzir efeitos positivos ao desenvolvimento da pessoa do adolescente ou de sua personalidade, porque se constituem apenas de regras de conduta que não se vinculam às suas condições contextuais, dai não influirem sobre elas, caindo, possivelmente, no vazio, quando situadas no seu cotidiano.

Por outro lado, é preciso considerar, que embora o conjunto de procedimentos à que nomeamos medidas, não sinalize para a tentativa de compreender o significado das condutas, para além dos "atos infracionais", no conjunto da história tanto do adolescente em sua família, quanto dessa família em seu contexto sócio-econômico e cultural, tanto a intervenção do setor técnico, quanto a posição da autoridade judiciária, ao solicitar essa intervenção, representam, para nós, indícios de esforços, na direção de uma compreensão 
mais abrangente, da própria situação; contudo, é preciso que se diga, que apesar dos esforços do setor técnico, quando faz sua avaliação detalhada do "caso" e seu acompanhamento, isto se perde, quando resulta em orientação desprovida da oferta de outros recursos, para nós condicionais na instrumentalização da família e do próprio adolescente para modificar sua situação. Orientação e boa vontade, embora necessários, não bastam, menos ainda quando se tem por expectativa a mudança de comportamento.

É importante observar as frequências dessas medidas, no conjunto dos processos de cada ano estudado. Nas Tabelas 8, 9 e 10, relativas, respectivamente, aos anos de 1986, 1991 e 1996, apresentamos todas elas, seguindo a ordem decrescente de sua frequência de aplicação. ${ }^{7}$ Notar-se-ão diferenças de um para outro ano; tais diferenças, contudo, não representam mudanças na natureza dos procedimentos, que mantêm-se não apenas circunscritos ao âmbito judicial, de natureza disciplinar, tutelar e correcional-punitiva, mas limitados à ação do sujeito (e respectiva família) a ser disciplinado, orientado, corrigido, punido ou "recuperado"; mesmo nos 5 casos, de 1996 (2 de encaminhamento ao Conselho Tutelar e 3, em que o Juiz determinou que os mesmos se submetessem à "orientação, apoio e acompanhamento" por esse Conselho), a perspectiva é a mesma. A única exceção, nos parece, está em 2 casos, do ano de 1991, em que foi determinado além do estudo social, o encaminhamento à programa.

A Tabela 8 apresenta os tipos de medida identificados nos registros dos processos relativos às situações ditas infracionais, do ano de 1986 e suas respectivas frequências. Aí encontramos as medidas de: advertência; estudo social; orientação; arquivamento; internação; entrega; entrega e advertência à família; destituição de pátrio poder e abrigo. Dessas, a mais frequentemente adotada foi a advertência, aplicada à maioria expressiva dos casos, ou seja, a 278 casos, os quais representam 66,7\% do total dos 417 ditos infracionais desse ano. Em 27 desses 278 casos, o Setor Técnico do Fórum foi chamado a intervir; em 15, com estudo social ( 10 antecederam a aplicação da advertência e os outros 5 seguiramna), em 11 com orientação e em 1 caso com estudo social e orientação. A segunda mais frequente resposta da autoridade judiciária, às situações ditas infracionais de 1986, foi o

\footnotetext{
${ }^{7}$ Tomamos o cuidado de apresentá-las todas, registrando-as conforme sua ocorrência e ordem de aparecimento nos registros de cada processo, assim como, conforme registradas no próprio enunciado de cada sentença ou vistos finais do juiz, que explicitasse a decisão dessa autoridade sobre aquela situaçăo. Por essa razăo, as tabelas são detalhadas. Ao mesmo tempo, contudo, utilizamos como critério, ao descrever as tabelas, evidenciar determinados tipos de medida, entre aqueles encontrados, conforme sua correspondência com os tipos na legislação.
} 
arquivamento dos casos, determinado em 113 casos, ou seja em 27,1\% do total de casos; em 7 deles o Setor Técnico do Fórum foi chamado a intervir com estudo social, antecedendo a decisão do arquivamento.

Tabela 8. Medidas aplicadas pelo Juízo da Infância e da Juventude da Comarca de São Carlos, nas situaçōes ditas infracionais, no ano de 1986 e respectivas frequências ${ }^{8}$.

\begin{tabular}{|c|c|c|}
\hline Medidas & N. & $\%$ \\
\hline Advertência & 251 & 60,2 \\
\hline Advertência e estudo social & 10 & 2,4 \\
\hline Advertência e orientação & 11 & 2,6 \\
\hline Estudo social e advertência & 05 & 1,2 \\
\hline Estudo social, advertência e orientação & 01 & $\mathbf{0 , 2}$ \\
\hline Arquivamento & 106 & 25,4 \\
\hline Estudo social e arquivamento & 07 & 1,7 \\
\hline Internação & 02 & 0,5 \\
\hline Estudo social e internação & 05 & $\mathbf{1 , 2}$ \\
\hline Näo infiracional & $\begin{array}{c}18 \\
(02)\end{array}$ & $\begin{array}{c}4,3 \\
(0.5)\end{array}$ \\
\hline Entrega e advertencia d familia & (01) & $(0,2)$ \\
\hline Estudo social e entrega e advertência d familia & (01) & $(0,2)$ \\
\hline Abrigo & (01) & $(0,2)$ \\
\hline Estudo social, destituiçũo de pátrio poder e abrigo & (01) & $(0,2)$ \\
\hline Arquivamento & (06) & (1,4) \\
\hline Estudo social e arquivamento & (06) & $(1,4)$ \\
\hline Não consta a medida & 01 & 0,2 \\
\hline Total & 417* & 100,0 \\
\hline
\end{tabular}

A internaçăo, pouco expressiva, comparativamente à advertência e ao arquivamento, foi determinada em 7 casos, os quais correspondem a 1,7\% dos casos ditos infracionais desse ano; em 2 desses 7, o Setor Técnico foi previamente chamado a intervir com estudo social. Há ainda um percentual de 4,3\%, ou seja 18 casos, que embora registrados como sindicância, foram tratados como "não infracionais", através de medidas como estudo social, abrigo, destituição de pátrio poder, entrega e advertencia à família e arquivamento.

Nesse ano, 1986, não aparecem registros de ocorrência de aplicação de outras medidas previstas no Código de Menores, como a de "liberdade assistida", que aparece nos anos de 1991 e 1996, e a "colocação em casa de semiliberdade", que não aparece em nenhum dos anos estudados. Destaca-se, contudo, nesse ano, diversamente do que ocorre em 1991 e 
1996, o importante percentual de intervenções do setor técnico do Fórum, que se deu em 39 dos casos ditos infracionais desse ano, ou seja, em 9,4\% desse total; somados a 10 daqueles casos, registrados como sindicância, mas conduzidos como "não infracionais", esse percentual de intervenção de técnicos aumenta para $11,8 \%$.

No conjunto dessas medidas, o que mais nos chama a atenção, é o percentual de aplicação da advertência; essa medida é adotada nos três anos de estudo, embora expressivamente mais frequente, que os demais tipos de medida encontrados nesses três anos, apresenta queda considerável, na sua aplicação, quando considerados seus percentuais para os anos de 1986 e 1991, o que pode representar alguma influência da mudança da lei, (BRASIL, 1990), uma vez que enquanto ocorrem quedas nos percentuais de advertência, aparecem expressivos percentuais de remissão e representação (ambos facultados pela nova lei).

Definida no ECA (art. 115), como "admoestação verbal", "que será reduzida a termo e assinada", a advertência "obsta", segundo ALBERGARIA (1991), "ao emprego de medidas mais graves, em razão de escassa gravidade da situação do menor". De acordo com o mesmo autor, "pela advertência, verifica-se o primeiro contato do menor com a autoridade", o qual "poderá ser decisivo para o menor: ou será o começo de sua recuperação ou início de sua carreira no crime", por isso o autor a considera "medida tutelar, e não sanção repressiva"; acredita o autor que "...o primeiro contato com o agente do Poder Público, mediante formalismo, indiferença ou rispidez, poderá provocar uma atitude de reação ou oposição, marcando o início da carreira da delinquência...", que "...num clima humano e sem tensões, dar-se-á o começo da obra de recuperação do menor", mas, alerta-nos para o fato de que "...a praxe burocrática, a pressa do juiz ou sua substituição por funcionário retiram da advertência seu caráter tutelar, para exacerbar a situação do abandono do menor"9.

A posição desse autor mostra concepções semelhantes às encontradas nos processos estudados dos três anos de estudo, relativamente ao adolescente, ao qual se persiste tratando como "menor" (até porque não se deixou de vê-lo como tal), à natureza do problema, ainda tomado como de desvio estrutural do sujeito (por isso fadado ao crime e, portanto, necessitado de recuperação) e à representação social da autoridade judiciária (magnitude do poder da figura da autoridade judiciária). Essa posição parece estender-se a outros

\footnotetext{
${ }^{8}$ Anexo 32 apresenta o Quadro geral com todas as medidas aplicadas.
} 
representantes do Poder Judiciárío e, pelo que temos visto, parece representar o pensamento de muitos outros; essa é nossa impressão, baseada não apenas no teor dos pareceres contidos nos registros dos processos, dos três anos estudados, como nas posições defendidas nos debates que temos tido oportunidade de acompanhar ou participar, ao longo dos últimos 6 anos; também corroboram essas impressões, a análise de um número considerável de ações (das propostas, aos cursos, aos projetos, aos relatórios, aos programas, enfím...) por nós já levantados. Há, nos parece, o que poderíamos chamar de 'excesso de confiança', no próprio poder e na representação social do papel exercido, ou do cargo e atribuições devidas e, em função disso, expectativa de respostas, tais como a mudança de comportamento daquele sobre o qual se exerce o suposto poder; se assim é, contudo, não se aplica, evidentemente, apenas ao âmbito do Poder Judiciário dizendo, provavelmente, respeito a todos nós, quando nos relacionamos com esses meninos, porque muitos de nós, certamente, os vemos da mesma forma com que o vê aquele autor.

Relativamente ao ano de 1991, Tabela 9, encontramos as medidas de: arquivamento; estudo social; abrigo; acompanhamento pelo setor técnico; remissão; representação; advertência; liberdade assistida; recambiamento; apensamento a outro processo em curso; internação; orientação, apoio e acompanhamento temporários pelo setor técnico; inclusão em programa de tratamento; obrigação de matrícula e frequência em escola; encaminhamento a programa; reparação de danos; busca e apreensão; entrega; advertência à família.

\footnotetext{
${ }^{9}$ Os grifos são nossos, porque sao termos dos quais divergimos.
} 
Tabela 9. Medidas aplicadas pelo Juízo da Infância e da Juventude da Comarca de São Carlos, nas situações ditas infracionais, no ano de 1991 e respectivas frequências.

Medidas

N. $\%$

Arquivamento

$304 \quad 44,7$

Representação e arquivamento

Estudo social e arquivamento

Abrigo, acompanhamento pelo setor técnico e arquivamento

$10 \quad 1,5$

030,4

010,1

Remissão

$240 \quad 35,3$

Representação e remissão

Estudo social e remissão

030,4

Advertência

01

01

0,1

Representação e advertência

28

0,1

Estudo social, acompanhamento pelo setor técnico e advertência

01

Remissão e advertência

Representação, remissão e advertência

213,1

010,1

Representação e liberdade assistida

Recambiamento e arquivamento

Apensamento

Representação e apensamento

\section{Internação}

020,3

$02 \quad 0,3$

Representação e internação

Estudo social, abrigo, acompanhamento pelo setor técnico e

$03 \quad 0,4$

Internação

010,1

Remissão, orientação, apoio e acompanhamento temporários pelo

setor técnico e inclusão em programa de tratamento

Remissão e obrigação de matrícula e frequência em escola

Representação, remissão, acompanhamento pelo setor técnico e

obrigação de matrícula e frequência em escola

020,3

Estudo social e encaminhamento à programa

020,3

Remissão, reparação de danos e advertência

010,1

Representação, advertência e liberdade assistida

010,1

Representação e Busca e apreensão

010,1

Não infracional

*excluídos os não localizados (4 casos) e os remetidos a outro Cartório ou Comarca (3 casos) 
Pode-se ver, que nesse ano, a autoridade judiciária respondeu às situações ditas infracionais, com maior diversidade de medidas, do que no ano de 1986. A medida aplicada com mais frequência foi, em 1991, o arquivamento. Foi determinado em 318 casos, os quais correspondem a 46,8\% do total de casos ditos infracionais desse ano. Desses 318,10 casos foram antecedidos de representação, 3 de estudo social e 1 de abrigo e acompanhamento pelo setor técnico. A segunda medida mais adotada foi a remissão. Foi concedida a 244 , do total de 680 casos de 1991, o equivalente a $35,9 \%$ deles; entre esses 244 casos, houve 3 precedidos de representação e 1 de estudo social.

Os demais tipos de medida encontrados nesse ano, foram bem menos expressivos. Em 30 casos, ou $4,4 \%$ do total dos casos ditos infracionais do mesmo ano, a autoridade judiciária decidiu pela aplicação da advertência, 28 deles foram precedidos de representação e em apenas 1 caso o setor técnico foi chamado a intervir com prévio estudo social e acompanhamento. Em 22 casos, ou 3,2\%, optou pela remissão cumulada com advertência, sendo 1 caso precedido de representação; em 17 casos $(2,5 \%)$ decidiu pela aplicação de liberdade assistida, ocorrendo previa representação em todos eles. Determinou o apensamento do processo a outros em curso, em 11 casos $(1,6 \%), 2$ deles antecedidos de representação. Em 6 casos $(0,9 \%)$ determinou a internação, 3 deles foram precedidos de representação e 1 de estudo social, abrigo e acompanhamento pelo setor técnico. Em 3 casos $(0,4 \%)$ aplicou a remissão cumulada com orientação, apoio e acompanhamento temporários pelo setor técnico e inclusão em programa de tratamento. Aplicou ainda, em 2 casos $(0,3 \%)$, a remissão cumulada com obrigação de matrícula e frequência em escola; em outros 2 , representados, a remissão cumulada com acompanhamento pelo setor técnico e obrigação de matrícula e frequência em escola. Foram também apenas 2 os casos em que decidiu pelo encaminhamento a programa, ambos antecedidos de estudo social. Além desses, o Juizo aplicou a 1 caso a remissão cumulada com reparação de danos e advertência, a outro, representado, advertência e liberdade assistida e a 1 último, também representado, a busca e apreensão. Como em 1986, há também nesse ano, um pequeno percentual $(1,2 \%)$ de medidas, como abrigo e entrega e advertência à família, aplicadas em 8 casos, conduzidos como "não infracionais".

Os percentuais de intervenção do setor técnico caem bastante em relação ao ano de 1986 , passando dos quase $12 \%$ desse ano, para $2,1 \% \mathrm{em} \mathrm{1991.} \mathrm{Por} \mathrm{outro} \mathrm{lado,} \mathrm{aparecem} \mathrm{as}$ 
representações do Ministério Público, apresentadas em 68 casos, o equivalente a 10\% do total de casos ditos infracionais desse ano.

É importante destacar que a nova legislação (BRASIL, 1990), que normatiza a possibilidade da representação pelo Ministério Público, faculta também a remissão. Se observarmos as Tabelas 9 e 10, veremos que sua frequência de aplicação aumenta de 1991 para 1996, vindo a se constituir a medida mais utilizada do ano de 1996. De acordo com o art. 126, "antes de iniciado o procedimento judicial para apuração de ato infracional, o representante do Ministério Público poderá conceder a remissão, como forma de exclusão do processo, atendendo às circunstâncias e consequências do fato, ao contexto social, bem como à personalidade do adolescente e sua maior ou menor participação no ato infracional"; o parágrafo único desse mesmo artigo define ainda, que "iniciado o procedimento, a concessão da remissão pela autoridade judiciária importará na suspensão ou extinção do processo".

CURY et al (2000) chamam a remissão, anterior ao início do procedimento para apuração de ato infracional, de "remissão pré-processual" e a outra (...iniciado o procedimento...) de "remissão judicial". Embora sejam "duas espécies de remissão, uma anterior ao processo, atribuição do Ministério Público e outra já iniciado o procedimento e da competência do Juiz", conforme explica ALBERGARIA (1991), o termo, remissão, "não é adequado", tratando-se do "perdão judicial, que é a faculdade atribuída ao juiz de não impor a pena, quando o fato é de escassa gravidade e culpabilidade". Segundo deduzimos, do texto desse mesmo autor, que faz referência a outros, essa remissão, seria a "desjudicialização", que teria "por objetivo manter os indivíduos fora da justiça penal", o equivalente a optar "pela via não processual", onde "exclui-se o culpado do processo penal, corrigindo-o com outros meios de caráter não penal ${ }^{l 0 "}$.

Para nós, a medida mereceria reflexão, principalmente, se considerarmos sua aplicação cumulada com outras medidas, por exemplo, "remissão e prestação de serviços à comunidade", "remissão e liberdade assistida", "remissão e advertência", entre outros, como ocorre em vários dos processos aqui estudados; embora facultados pela mesma lei, em seu artigo 127, que, tratando da remissão, estabelece: "...podendo incluir eventualmente a aplicação de qualquer das medidas previstas em lei, exceto a colocação em regime de semiliberdade e a internação...", (BRASIL, 1990), esses casos nos fizeram indagar acerca

${ }^{10}$ Grifos nossos 
do pressuposto ou concepção de 'remissão', em que se teriam baseado o legislador e as autoridades judiciais, quando optaram pela aplicação cumulada de duas condições, a nosso ver, conceitualmente opostas, como perdão e punição, ainda que de caráter "não penal".

Parte dessa aparente contradição parece residir no mesmo artigo, o 127, quando define que "a remissão não implica necessariamente o reconhecimento ou comprovação da responsabilidade, nem prevalece para efeito de antecedentes...", o que faz supor que se trata da ausência de culpa e daí a condição de perdão; segundo nosso entendimento, uma vez concedido o perdão, ou a remissão, dever-se-ía excluir a possibilidade de punição. Emprestando as referências do representante do Ministério Público dessa Comarca, num dos processos lidos, que dizia da "...concessão do perdão judicial, que nos termos da reforma penal é causa extintiva da punibilidade ${ }^{\prime \prime}$ arrolada entre outras no art. 107, do Código Penal...", talvez pudéssemos começar a discutir o sentido da inclusão, na lei, dessa modalidade de procedimento, antes de tomá-la precipitadamente por "condescendência" ou "indulgência" da lei, ou da autoridade judiciária, para com o adolescente; se existe intenção de indulgência na concessão dessa medida, a sua aplicação cumulada com outra medida restringe essa indulgência ao plano da intenção.

"Grifo nosso. 
Tabela 10. Medidas aplicadas pelo Juízo da Infância e da Juventude da Comarca de São Carlos, nas situações ditas infracionais, no ano de 1996 e respectivas frequências ${ }^{12}$. Medidas N. $\%$

\section{Remissão} $331 \quad 42,0$

Representação e remissão

Arquivamento

Representacilo e arquivamento

15319,4

Estudo social e arquivamento

Remissão e advertência

Representaçẵo, remissăo e advertência

Representacilo, remissilo e prestaçlo de serviços à comunidade

Remissão e liberdade assistida

Representação, remissã̃o e liberdade assistida

Representaç̃o e liberdade assistida

$10 \quad 1,3$

$29 \quad 3,7$

081,0

$22 \quad 2,8$

$08 \quad 1,0$

Representaçilo e internacilo

Representação e absolvição

Encaminhamento so Conselho Tutelar

030,4

Representação, liberdade assistida e prestação de serviços à comunidade

030,4

Apensamento

Advertência

$01 \quad 0,1$

Representação e advertência

Remissalo e orientagilo, apoio e acompanhamento pelo Conselho

Tutelar

020,3

Remissão, reparação de danos e prestação de serviços à comunidade

Remissto e orientaclo, apoio e acompanhamento pelo setor téenico

\section{0,1}

788* 100,0

Total

Comarca (7casos)

Quanto das medidas aplicadas no ano de 1996, encontramos alguns dos tipos já referidos nos outros anos, como: remissâo; representação; arquivamento; estudo social; advertência; liberdade assistida; internação; apensamento a outro processo em curso; reparação de danos e orientação, apoio e acompanhamento pelo setor técnico; além desses,

\footnotetext{
12 Anexo 33 apresenta o Quadro geral das medidas aplicadas para os 3 anos, com os respectivos percentuais encontrados.
} 
outros como: prestação de serviços à comunidade; encaminhamento ao Conselho Tutelar; absolvição e orientação, apoio e acompanhamento pelo Conselho Tutelar.

Como vimos, a resposta mais adotada pelo Juízo, nesse ano, foi conceder a remissão. Isso ocorreu com o expressivo contingente de $50,5 \%$ dos 788 casos ditos infracionais desse ano; foram 398 casos, 67 dos quais precedidos de rep esentação. A segunda medida mais aplicada pela autoridade judiciária foi, como ocorreu em 1986, o arquivamento, determinado em $21,2 \%$ dos casos; desses, 13 foram precedidos de representação e 1 de estudo social.

É importante destacar que, além de ser medida adotada nos três anos de estudo, o arquivamento é expressivo em todos eles. Relativamente ao inciso I, do art. 180, que faculta ao representante do Ministério Público "promover o arquivamento dos autos...", CURY et al (2000), acerca da sua aplicabilidade, explicitam-nos, "...quando inexistente o fato, não constituir ele ato infracional ou não for o adolescente seu autor". Diante disso e do expressivo percentual de aplicação desse tipo de procedimento, ou medida, encontrado no universo estudado (2a. mais aplicada em 1986 (27,1\%); 1a., em 1991, (46,8\%) e 2a., em $1996(21,2 \%))$, podemos pensar no contingente expressivo de situações que vem sendo encaminhadas ao fórum, nesses anos, porque relativas à suposta prática de ato infracional, nas quais “.....inexiste o fato..." ou “...o fato não constitui ato infracional...” ou “...o adolescente não é seu autor". Ao levarmos em conta os pareceres, que acompanham esses arquivamentos, isso se confirma.

A título de ilustração, apresentamos algumas das motivações encontradas nos processos, para o seu arquivamento.

Relativas ao ano de 1986: "...não existe prova suficiente..."; "...os fatos não ficaram bem demonstrados..."; "...o fato não se reveste de gravidade..."; "..não requer soluçâo jurídica..."; "...caso insignificante..."; "...o caso teve consequências insignificantes..."; "...prova... insuficiente para lançar qualquer punição..."; "...nega a prática... ...nenhuma prova foi produzida no sentido de demonstrar o contrário..."; "...não cometeu o fato que lhe é imputado..."; "...não há prova da materialidade da infração..."; "...não cometeu o fato que lhe é imputado..."; "..os fatos não são graves... e a tramitação da sindicância já serviu de advertência..."; "...impossibilidade de ser encontrado o verdadeiro responsável..."; "...já indenizou a vítima... e a tramitação da sindicância já serviu de punição por eventual excesso que 
o menor tenha cometido..."; "...o fato foi esclarecido..."; "...caso de internação hospitalar..."; "...tenra idade... fato insignificante..."; "...completou a maioridade..."; "...não ter tido a intenção... res-furtiva restituida...".

Relativas ao ano de 1991: "...não configura conduta anti-social..."; "...infração não é típica, não configurando ato infracional para efeito de aplicação de medida sócioeducativa nos termos dos arts. 103 e 112 do ECA..."; "... a conduta não configura ato infracional...": "... insuficiente para apurar qualquer responsabilidade..."; "...absolvese por deficiência de provas..."; "...à vista do ressarcimento do prejuizo..."; "...já foi severamente advertido...": "...atingiu a maioridade penal, sendo agora responsável por seus atos..."; "...não existe prova suficiente de ter concorrido para o ato..."; "... não ficou caracterizada a prática do ato infracional..."; "... não restou comprovada a materialidade infracional..."; "...a conduta do menor é atipica..."; "...não é grave..."; "...não é típica..."; "...não registra passagens..."; "...não sendo patente a existência de ato infracional ou mesmo de dados esclarecedores sobre a autoria..."; "...não há crime a se punir..."; "...in dubio pro reu..."; "...a idade do acusado..."; "...não chegou às vias de fato..."; "...não se sabe quem agrediu ou quem se defendeu..."; "...não passou do âmbito doméstico..."; "...não foi localizado... está em local incerto e não sabido..."; "... furto em prejuizo do ascendente..."; "...aguarda nova provocação..."; "... ato infracional praticada por criança...".

Relativas ao ano de 1996: "... a autoria não foi esclarecida..."; "...dúvida sobre a ocorrência do ato..."; "...não há noticia de crime..."; "...não há dados sobre eventual crime praticado pelo menor..."; "..não houve prática de ato ilicito..."; "..não vislumbro ato infracional..."; "...completou a maioridade penal..."; "...inexistem elementos para a formulação de representação...": "...não há base para a instauração de processo..."; ".. o fato refoge das atribuições deste Juizado..."'; "...não há provas de que os bens encontrados são de origem criminosa..."; "...o crime é de ação privada..."; "..precariedade de provas quanto à autoria ..."; "...pobreza dos dados fáticos acrescentados com as negativas dos adolescentes..."; "...pouca idade... menor de 12 anos..."; "...nenhuma consequência... inclusive dúvida sobre a ocorrência do fato típico..."; "...o expediente é omisso na descrição das circunstâncias $e$ 
consequências do fato, ...emérgindo do histórico do B.O. sérias dúvidas sobre se são, efetivamente os referidos suspeitos os autores do episódio..."; "...o fato é atipico..."; "...não hà elementos suficientes para propositura de representação..."; "..não vislumbro qualquer necessidade de aplicação de medida ao adolescente..."; "..não vislumbro a existência de infração..."; "...não apurada a autoria..."; "..fato relatado não configura ato infracional..."; "...negou os fatos e foi advertido..."; "..fato não encontra tipo legal...": "...não há provas de que... (objetos)...são oriundos de crime..."; "..processo em duplicata..."; "...prova existente não aponta ...( o adolescente) como sendo o autor..."; "..problema de natureza familiar..."; "..não passou de ligeira discussão, sem consequências..."; "...não interesse da vítima em representar..."; "...não houve prática de ato (libidinoso)..."; "...(agressão) mútua... sem testemunhas..."; "...não há elementos que justifique imposição de medida ao adolescente...".

Quanto às demais medidas encontradas no ano de 1996, a remissão cumulada com aplicação de advertência ocupa o terceiro lugar, tendo sido adotada em 118 casos, 9 dos quais precedidos de representação, o correspondente, portanto, a $15 \%$ dos casos ditos infracionais do ano. A remissão cumulada com prestação de serviços à comunidade também foi aplicada pelo Juízo, num total de $4,9 \%$ dos casos ditos infracionais desse ano; correspondem a 39 casos, entre os quais 10 precedidos de representação. Em outros $3,8 \%$ dos casos, o Juízo concedeu remissão cumulada com liberdade assistida; correspondem a 30 casos, 22 deles representados. As demais medidas aplicadas nesse ano, mostram percentuais bem menos expressivos, não ultrapassando 1\%. A internação foi determinada em 8 casos, o mesmo ocorrendo com a liberdade assistida, que se aplicou em $1 \%$ dos casos; todos eles precedidos de representação. Outros 4 casos, também representados, receberam absolvição. Nesse ano encontramos 3 casos, em que o Juízo decidiu pelo encaminhamento ao Conselho Tutelar e outros 2, pela remissão cumulada com orientação, apoio e acompanhamento pelo Conselho Tutelar. Há mais 3 casos, em que o Juízo optou pela aplicação de liberdade assistida cumulada com prestação de serviços à comunidade, todos precedidos de representação e outros 2 , de remissão cumulada com reparação de danos e prestação de serviços à comunidade. Como em 1991, também em 1996 ocorrem casos de apensamento do processo a outro em curso; foram 3 casos. A advertência também foi adotada, mas em 
apenas 2 casos, 1 deles representado. Num único caso, o Juízo concedeu a remissão cumulada com orientação, apoio e acompanhamento pelo setor técnico.

Destaca-se, ainda, o percentual inexpressivo de intervenções do setor técnico; enquanto em 1986 essas intervenções foram aplicadas para quase 12\% do total dos casos infracionais do ano, caindo para os 2,1\% em 1991, em 1996, a diferença é ostensiva, não tendo sido solicitada para mais que $0,2 \%$ desses casos, nesse ano. Se, contudo, o setor técnico pouco foi chamado a intervir, tanto em 1991 quanto em 1996, de outro lado, as representações do Ministério Público, apresentam comportamento inverso; aumentam dos $10 \%$, relativos ao ano de 1991 , para quase $21 \%$, em 1996. A questão merece algumas considerações. Apresentamos alguns elementos úteis à reflexão.

A representação está prevista no art. 180, do ECA (BRASIL, 1990), como uma de três possibilidades de escolha, pelo Ministério Público, para o encaminhamento da situação; de acordo com esse artigo "...o representante do Ministério Público poderá: I - promover o arquivamento dos autos; II - conceder a remissão; III - representar à autoridade judiciária para aplicação de medida sócio-educativa". O artigo 182 diz das condições de sua adoção: "se por qualquer razão, o representante do Ministério Público não promover o arquivamento ou conceder a remissão, oferecerá representação à autoridade judiciária, propondo instauração de procedimento para aplicação de medida sócio-educativa que se afigurar mais adequada". O parágrafo $1^{\circ}$, desse mesmo artigo, explica que a "...representação será oferecida por petição, que conterá o breve resumo dos fatos e a classificação do ato infracional e, quando necessário, o rol de testemunhas..." e o $2^{\circ}$, que essa "...independe de prova pré-constituída da autoria e materialidade".

Diante disso, indaga-se: quando na lei se propõe "...instauração de procedimento para aplicação de medida sócio-educativa que se afigurar mais adequada...", não se estaria fazendo uso do pressuposto de culpa, contrariamente ao pressuposto de que "somos inocentes até que se prove o contrário"? Nos registros dos processos lidos, em que aparecem as representaçð̃es, encontramos além da forma prevista na lei, outra, que a nós parece mais adequada (por suposta ausência do pressuposto de culpa): no lugar de "instauração de procedimento para aplicação de medida sócio-educativa", o representante do Ministério Público propõe "instauração de procedimento para apuração de ato infracional".

Se, além disso, conforme afirmaram CURY et al (2000), trata-se de "...ação sócioeducativa pública, passível de instauração qualquer que seja o ato infracional e 
recomendável nas infrações graves ${ }^{\prime 3}$...", como pode prescindir de "prova pré-constituída da autoria e materialidade" (art. 182, par. 2, ECA) (BRASIL, 1990)?

Do nosso ponto de vista, também esse procedimento mereceria maior reflexão, do que a nós parece ocorrer, mesmo porque uma vez constituído, implica a obrigatoriedade de defesa do adolescente; conforme consta nos termos de muitas dessas representações, ele "praticou, em tese" "a conduta descrita no artigo....", demandando, portanto, a necessidade da produção de provas de sua inocência (novamente, o pressuposto é o de culpa, até que se prove o contrário). Assim, a presença de representação, não apenas constitui maior complexidade de procedimentos, como muda a própria natureza do processo, que de "Apuração de Ato Infracional de Adolescente", transforma-se em "Äção Sócio-Educativa Pública"; para nós, traduz maior severidade no trato da questão, emprestando à situação uma espécie de gravidade, que mais nos parece servir a justificar o seu trato pelo judiciário, que a construir possibilidades de aprendizado, para a criança ou adolescente envolvido nessa situação.

Um último destaque se faz necessário. Refere-se à medida de internação, prevista, conforme já referimos, tanto na lei revogada (Brasil, 1979), como na lei em vigor (BRASIL, 1990).

"A internação constitui medida privativa da liberdade, sujeita aos princípios de brevidade, excepcionalidade e respeito à condição peculiar de pessoa em desenvolvimento" e "...só poderá ser aplicada quando: I - tratar-se de ato infracional cometido mediante grave ameaça ou violência à pessoa; II - por reiteração no cometimento de outras infrações graves; III - por descumprimento reiterado e injustificável da medida anteriormente imposta" (arts. 121 e 122, ECA) (BRASiL, 1990).

Primeiro, é preciso que se aponte que o número de internações, encontrado nos três anos de estudo, é pouco expressivo, relativamente aos demais tipos de medida aplicados nesses mesmos anos. Isso pode indicar que as internações são mesmo evitadas, obedecendo à recomendação da própria legislação, ao contrário do que nossos preconceitos faziam supor, que encontraríamos um contingente expressivo de internações. Além disso, os números encontrados contrariam a queixa institucional (FEBEM), verbalizada por técnicos da instituição e divulgada pela imprensa, de que o interior do Estado tem sido o grande

\footnotetext{
${ }^{13}$ grifo nosso.
} 
responsável pelo maior contingeñte de internos na FEBEM; se isso de fato ocorre, então a Comarca de São Carlos é exceção.

Se os números são pouco expressivos, chama-nos a atenção, contudo, a natureza dos casos em que as internações foram determinadas: homicídio (1986, 1991 e 1996), roubo (1991 e 1996) e furto (1986, 1991 e 1996); se nos casos de homicídio e roubo, a gravidade é explícita, no caso do furto, esse critério não se aplica, ocorrendo por razões como o descumprimento de medida anteriormente imposta ou a reiteração da infração, motiv da "caracterização" do adolescente como "portador de diversas passagens". Isso sugere que minimamente nesses casos, deveríamos refletir, quanto a outras possibilidades, dada a natureza essencialmente material da infração. Além disso, se a intenção tem sido a de "corrigir", como se espera fazê-lo numa instituição, cujo modelo já demonstrou falência?

Supondo que os operadores do direito não desconhecem as condições institucionais da internação, acreditamos que as internaçðes continuam ocorrendo, a despeito da falência do modelo institucional existente, por pelo menos duas razões: uma, a lei prevê essa possibilidade, outra, a falta de alternativas, como o encaminhamento a programas oficiais destinados ao atendimento da criança e do adolescente, em situação de maior vulnerabilidade, dada a omissão do Poder Público na sua oferta.

Lamentavelmente, portanto, apesar de tudo o que sabemos e vimos acerca desse modelo, continuamos optando pela internação, garantindo, ao fazê-lo, exclusivamente o confinamento, desses meninos; prosseguimos submetendo-os não só à privação da liberdade, como às condições desumanas da Instituição, que se perpetua a despeito de todas as evidências para o seu desmantelamento; e o fazemos, respaldados pela lei, que nos garante, entre outros, o direito de nos vingarmos de alguns dos que se atrevem a desafiar a justiça humana, descumprindo a lei.

Lamentavelmente, é assim que concluímos a discussão dos resultados desse estudo, porque não encontramos outro tipo de resposta, que não a punição dos meninos e seus pais, vistos como os principais responsáveis pela "sua" "conduta infracional". Não fồra uma única exceção, que ocorreu nos processos do ano de 1991, não poderíamos afirmar que outras garantias, previstas em lei, não estão sendo resguardadas. Nesse ano, a autoridade judiciária, com sustentação na falta de programas e serviços, para onde encaminhar crianças e adolescentes, que passaram pelo Judiciário, reclama providências do Município e do Estado. 
Isso nos mostra que ao Judiciário cabe também atuar sobre o descumprimento de outras responsabilidades, que não só a dos meninos e seus pais, como a do Poder Executivo, na oferta de equipamentos, programas e serviços oficiais, que garantam o acesso desses meninos e suas famílias, ao exercicio dos seus direitos fundamentais. Se os pais são responsabilizados mediante o abandono, a omissão ou negligência dos filhos, o Estado ou Poder Público é também responsável pelo anterior abandono, omissão ou negligência da família.

Essa é, do nosso ponto de vista, a discussão mais importante, a ser empreendida adiante; não se restringe, evidentemente, a uns ou outros do Poder Público, mas a nós todos, que com isso nos importamos. O que fazer diante de um crescente número de famílias, crianças e adolescentes, cuja condição econômica não faculta oportunidade para o acesso ao exercício de seus direitos; como reverter (reverter?!) essa situação, por conta da qual muitos deles acabam tendo que se submeter à humilhação de mendigar e ainda pagar por isso, posto que a mendicância também pode significar infração à lei?; "resolver" com assistência social e "moral" ou, com punição, quando se recusam à humilhação de pedir ou de receber da nossa caridade e se atrevem a "tomar" o que é nosso?

Parece que esperar que nossos meninos se conformem em ser "pobres, mas honestos e trabalhadores", como crescemos ouvindo e acreditando, não funciona mais. Talvez esteja na hora de refletir, por que razão nos atribuímos o dever da sua proteção integral, na mesma lei em que nos autorizamos a puní-los. 


\section{Considerações Finais}

\section{|||||||||Acerca da caracterização dessas crianças e adolescentes...}

Depois de ir e voltar tantas vezes, de ler e reler tantos processos, de comparar dados de transcrição com os dos Livros e os dos processos, de tantas consultas e novas leituras, corrigindo erros e anotando diferenças e lacunas de registros, depois de outras tantas consultas que nunca se esgotavam, posto que à dúvida sanada, uma nova pergunta se seguia, depois, enfim, de tantos processos lidos, consultados e relidos, chegamos a uma delicada conclusão. Não faz diferença, não importa, de que tipo de processo estejamos falando, ou qual a natureza da situação, se apuração de ato infracional de adolescente, se sindicância, se averiguação, se pedido de providência, se destituição de pátrio poder, enfim, a criança e o adolescente que chegam à delegacia e/ou ao Fórum e mesmo ao Conselho Tutelar, são vistos, "julgados", por uma ou outra via, segundo o critério de valor dos que estão temporariamente do "outro lado do balcão", como "necessitados" de ajuda e orientação, mas difíceis de aprender... ...ou, pessoas difíceis de lidar, problemáticas, inadequadas, despreparadas... ...e, muitas vezes, até como indivíduos destinados ao insucesso como pessoas de bem, fadados à delinquência, à vagabundagem e à mendicância.

Foi possível constatar que de fato eles não tem sido tomados como crianças e adolescentes, desvinculados de atributos estigmatizantes e discriminadores, que longe de se constituir característicos deles, derivam-se das situações que experimentam; por esse mecanismo, se continua tomando o que sofre, pelo sofrimento, ou melhor, o que vive o problema, pelo problema em si mesmo. É dessa forma que eles têm sido reduzidos à condição de "problema", desfigurados enquanto crianças e adolescentes e deformados em sua identidade de pessoa; é dessa forma que são responsabilizados, eles próprios e/ou suas familias, pelas circunstâncias que vivem e, que continuamos justificando, não apenas muitas das ações ou propostas centradas exclusivamente neles próprios e suas famílias, mas também muitas daquelas destinadas especialmente a eles e/ou suas famílias.

Talvez seja por isso que ainda dizemos, vemos e apontamos o "menor", o "infrator" quando os vemos, apesar de chamá-los "crianças e adolescentes"; talvez ainda não tenhamos aprendido a compreendê-los, no seu significado de ser pessoa, "em condição 
peculiar de desenvolvimento" e, portanto, não os alcancemos, para além do mero significado de sua conduta, num determinado momento e lugar.

Somos muito mais do que uma ação, uma atitude, um comportamento nosso; somos mais que o conjunto de nossas ações e mais que a soma dos nossos atributos. Somos o que pensamos, sentimos, fazemos e sabemos e, mais além, aquilo que não fazemos, que não sabemos, não sentimos e o que não somos capazes de definir acerca de nós próprios. Quem de nós se vê "traduzido" num simples "conjunto de coisas"? Quem de nós aceita ser vistu reduzidamente por um só aspecto do seu modo de ser? Se puséssemos lado a lado o que "sentimos ser" e o "dizer de nós", dariamos conta de expressar o que somos? Teriam o discurso, a comunicação conhecida, o conhecimento já experimentado, nos instrumentalizado de modo a expressar nossa totalidade?

Pensando nas coisas que fazemos, nos diferentes momentos do dia e ao longo dos dias pela vida, muitas se traduzem por papéis; mas, também não somos a somatória desses papéis. Somos também aquilo que não pudemos ser; aquilo que gostaríamos talvez de ser, ou quem sabe, preferiríamos ter escolhido ser, se nosso desejo não esbarrasse no do outro, ou se a livre escolha nos fosse dada. Assim, somos também nossos desejos não realizados e também tudo aquilo que nos foi negado; quantos "nãos" ouvimos, enquanto buscávamos crescer? E desses tantos, quantos pudemos, ou podemos compreender, quando vimos nossos desejos negados ou nossos sonhos minados?

Revivemos, ou reproduzimos, nos parece, nossa própria adolescência, nossa própria dificuldade de sermos ouvidos e compreendidos. Tornamo-nos adultos, abdicando de muito do que desejamos, enquanto adolescentes. E tornamo-nos igualmente surdos aos adolescentes que ai estão, desejosos de serem ouvidos e compreendidos... ...e o diálogo, talvez como conosco tenha sido, não se estabelece. Passamos daí a cobrar, esperar dele, aquilo que esperaram, cobraram de nós próprios... ...que abdiquem do seu modo de ser, do que gostariam de ser, para se tornar o que queremos que sejam. Assim como outros antes nos disseram o que era certo, também nós é que agora sabemos o que é certo; dai cobramos deles a mesma responsabilidade que de nós também cobraram. Esperamos, como esperaram de nós, que sejam, adultos "decentes", "sensatos", "morais", que resistam aos apelos de todo tipo a que estão expostos, no seu cotidiano. Se pudemos e tivemos que, por que eles não, não é mesmo? Se não pudemos ser tão espontâneos, contestadores, reivindicadores e 
determinados, quanto talvez tenhamos chegado a desejar, por que razão poderiam eles? Se não nos deram crédito, por que, afinal, acreditar neles?

Parece mesmo, que esperamos, a despeito de sua estrutura vulnerável e dividida, ambivalente e arrebatada, amedrontada e valente, contestadora, que sejam tenazes, cordatos e dóceis, que se submetam, que não desejem, não aspirem, não sonhem, com mais do que julgamos que devem.

Nos intriga a nossa "humana" natureza; protestamos nas circunstâncias e tempo que nos afetam... ...ultrapassado o embate, acomodamo-nos, protestando contra o outro, que ora ocupa o lugar, que antes foi nosso.

Ao que parece, não temos sido capazes, do gesto largo, de não ocupar o lugar do outro, como quem se vinga de alguma dor... ...e de nos deter, para ouvir e escutar nossos adolescentes... ...saber deles os sentimentos, os desejos, as posições e as razões... ...e mais do que isto, de lhes dar crédito... ...à eles, à sua palavra, aos seus desejos e às suas razões. Talvez, tenhamos o secreto medo do "descontrole"... ...ou, quem sabe, dos riscos de deparar com o que não nos é familiar... ...ou talvez até o contrário, com o que melhor conhecemos... ...nossa própria dor... ...dos nossos também minados, substituídos ou sublimados, "adolescentes desejos"... ..."sonhos de juventude"... .."românticos ideais".

\section{|||||||||Acerca das concepções encontradas....}

Vimos também, nos fragmentos de histórias de vida, que constituem os processos estudados, como é comum o uso de afirmações do tipo: "...não aceita orientação...", "...apresenta problemas de adaptação...", relativamente à criança e ao adolescente, em relatórios do setor técnico do Fórum, assim como no conteúdo de outros pareceres constitutivos de muitos dos processos lidos; esse é um importante indicador de que, para a Instituição, o problema está no sujeito; evidência incontestável disso é que a atenção se centra na modificação de comportamento desse sujeito e/ou de seus familiares.

Não é difícil verificar "associações" lineares nos conteúdos textuais dos relatórios e pareceres, entre "o comportamento" traduzido como "agressivo" ou que "não se adapta", relativamente a crianças ou adolescentes, que passaram por várias famílias (porque perderam um ou ambos os pais) ou instituições, (...como se fossem objetos tomados e devolvidos porque não se "harmonizam"/"combinam" com o que esses espaços lhes oferecem e permitem, ou não...) e a suposta "incapacidade" da criança ou adolescente para 
adaptar-se, sendo raro verificar, nesses textos, essa "associação" com um possível espaço inadequado à satisfação de suas necessidades; as raras vezes em que o espaço é dito inadequado, é o da família biológica dessa criança ou adolescente, frequentemente dita "desestruturada".

O mesmo ocorre em relatórios do Conselho Tutelar, onde é comum o uso de afirmações como "...apresenta déficit intelectual...", "...tem problemas mentais...", "apresenta tendências psicopáticas...", "apresenta problemas psiquiátricos...", "...é portadora de doença mental...", "...seu comportamento agressivo..."; isso é não apenas revelador da mesma concepção, mas contestável, do ponto de vista técnico, já que esse tipo de afirmação requer anterior habilitação profissional, o que não é requerido de um conselheiro tutelar, no exercício de sua função.

Correlatamente, as famílias dessas crianças e adolescentes, são reduzidamente tachadas e diagnosticadas como "desestruturadas" e esses pais e mães, comumente tomados por adultos despreparados, desorientados e não responsáveis, ou que "não exercem uma paternidade responsável". Adultos que "não cumprem seus deveres de pais" e que, mesmo "devidamente" "orientados" e/ou "advertidos", não se modificam, continuam não sendo bons pais.

A nós parece, que o conhecimento já produzido é mais que suficiente, para já termos abandonado a idéia, de que o exercício da paternidade responsável também é mera questão de caráter e de boa vontade. Já sabemos que o desempenho de papéis depende das condições de desenvolvimento pessoal que a tal nos habilite. Não somos adultos ao acaso; somos o adulto construído pela nossa própria história, uma história que começa antes de nossa concepção. Nascidos bebês, crescemos crianças e adolescemos, transformando-nos em jovens, que se tornam adultos, ou não... ...e enquanto muitos de nós envelhecem, outros de nós se vão no meio desse percurso. É um processo, um percurso, uma construção.

Assim como o papel profissional pede o desenvolvimento de habilidades para executar as tarefas próprias da profissão escolhidas, o papel de pai e mãe não prescinde do preparo para o seu desempenho. E o preparo reclama condições. Quantos de nós se julgam "habilitados", ou devidamente preparados nos seus respectivos papéis de pai e mãe? A considerar as condições, se ideais ou satisfatórias nossa possibilidade de adequação é certamente muito grande, mas e se adversas forem, quantos de nós conseguem ser bons e 
responsáveis pais? Teremos nós alcançado tal "condição de habilitação", como pais e profissionais, que nos consideremos autorizados a dizer do outro inadequado e não responsável?

Desconforta-nos sobremaneira o modo como temos nos valido de nossos conhecimentos, nas posições que ocupamos. Talvez a falta de melhor resposta, ou o medo da perda de posição, nos leve a essa forma de responder ao modo como o outro exerce seu papel de pai ou mãe... talvez nossa limitação de conhecimento, achando que ao outro faltá o "preparo", que supomos exist ir em nós... ...talvez o medo de encontrar-se diante do outro de igual para igual, sem diferenças, ver-se parecido, assemelhado ou identificado com aquele outro que condena.

Assim, se cobramos dos pais a "assistência material, moral e educacional dos filhos", a que a lei os obriga, (arts. 22 e 33; ECA), é preciso que avaliemos, também, as condições das quais depende qualquer um de nós, enquanto pai e mãe (tais como emprego, que custeie alimentação, vestuário, moradia (abrigo, espaço, saneamento básico, iluminação, gás, etc..), transporte, saúde, escola, lazer, profissionalização; equipamentos destinados à oferta de serviços de saúde, educação, profissionalização, esporte, cultura, lazer e condições materiais de acesso a esses equipamentos e seus serviços, entre outras), para a prestação dessa mesma assistência.

Esperar, portanto, adequações ou mudanças de comportamento, contando só com a disposição da criança ou adolescente, e/ou de suas famílias e, confiando no poder ou na força da orientação técnica e da aplicação de medidas, sem dispor da infra-estrutura social (equipamentos e programas públicos) necessários à "promoção social" (como se diz), dessas crianças, adolescentes e suas famílias, demonstra, para nós, que, na prática, somos sujeitos de posturas, que traduzem interpretações ambíguas, acerca do próprio conhecimento.

\section{|||||||||Acerca das nossas concepções sobre o comportamento da criança e o} adolescente...

Dos nossos estudos (EL-KHATIB, 1983, 1985, 1994, 1996, 1998) e experiência acumulada no atendimento e acompanhamento de crianças e adolescentes, da observação do desenvolvimento de crianças, ao longo de anos e das percepções acerca dos dados das crianças e adolescentes, contidos nos processos estudados, temos constatado que crianças 
conversam cada vez mais com máquinas, babás, e cuidadores, tanto caseiros, como profissionais ou institucionais e cada vez menos com pessoas, pais e mães; vem aprendendo gradativamente novos valores e conceitos derivados desse modo de crescer, desse tipo de relações, com os vídeos, computadores, games, tvs..., com os cuidadores, com a rua ...e com as instituições. Cada vez mais, crescem sem a presença dos pais, porque também não temos encontrado caminhos para enfrentar a falta de recursos sem que não apenas o pai, mas a mãe necessitem estar fora de casa, para garantir o pão de cada dia. Mais e mais precocemente, filhos não tem podido contar com a presença e assistência direta e contínua dos pais no seu dia a dia e, queiramos ou não, o desenvolvimento segue seu curso e nossas crianças seguem crescendo, vão tendo que buscar por si mesmas, respostas para suas curiosidades e desejos, nos momentos em que naturalmente surgem, pois essas não nos aguardam a chegada em casa, para se manifestar; vão aprendendo, assim, a "se virar" sozinhas e como, de fato, "se viram", acabam adquirindo uma espécie de "autonomia" com a qual não estamos habituados a lidar.

Acreditamos que elas vem sucessiva e obrigatoriamente aprendendo a resolver com seus próprios recursos, suas dificuldades, seus conflitos, suas necessidades e adquirindo autonomia cada vez mais cedo, aprendendo mesmo a resistir à disciplina e obediência às ordens de natureza parental ou institucional, porque muitas das próprias relações vem se restringindo a questões de deveres e obrigações. Vem ganhando, de fato, independência e autonomia em seus comportamentos, que nós, adultos, não apenas estranhamos mas, muitas vezes, rechaçamos, sem grande esforço de compreensão... ..muitas das vezes, sequer identificamos e nomeamos por desobediência e indisciplina, uma forma não apenas legítima, como saudável, de "sobreviver".

Talvez devêssemos nos indagar do como se tornaram tão firmemente decididas a defender seus próprios pontos de vista. Talvez diferentes de nós, por quem os pais falavam, tenham aprendido a falar por si mesmas... ...e a se defender, inclusive de nós. Talvez, parte das razões, para o comportamento da criança e do adolescente, possa residir mesmo em nós outros, na maneira como com eles nos relacionamos, ou no modo como os tratamos. Se pudermos refletir a respeito e, admitir a possibilidade, talvez possamos compreender, que certas condutas "delinquenciais", podem traduzir manifestações decorrentes do processo de interiorização, dos valores e expectivas, por nós neles introjetados. 


\section{|||||||||Acerca dos direitos e das nossas posições...}

Do ponto de vista do direito, no âmbito, portanto, da lei, somos iguais, detemos os mesmos direitos; no cotidiano, essa "igualdade" é relativa, ganhando, ou não, consistência, de acordo com as posições por nós ocupadas. Diferentes posições, consignam diferentes oportunidades, definindo limites de escolha ou de possibilidades, inclusive de projetos, ou não, de vida; vivemos, assim, o exercício relativo do direito ou, nos limites decorrentes das posições, que ocupamos uns em relação aos outros.

Para nós não mais se trata de mera contradição entre lei e prática, como antes supúnhamos. Hoje, sabemos que a lei, em si mesma, pode conter profundas contradições. Contudo, se partirmos do ponto de vista, dos principios que a norteiam, podemos tomá-la, ainda que à luz das suas limitações, como meta a ser alcançada. Nesse caso, ocorre que a lei, por si mesma não se garante, passando a depender do efetivo investimento de recursos, nas áreas do orçamento público, de modo a nos instrumentalizar para a eliminação de desigualdades, que tornaria possível o igual exercício de direitos, caso contrário, ela prossegue nos servindo parcial e individualmente, funcionando, no âmbito coletivo, apenas como distensor das tensões sociais, derivadas da sua garantia, "no papel", e do seu não cumprimento, "na hora h".

Tomá-la por meta ou diretriz, a ser discutida e analisada, modificada e apreendida, num esforço de reconstrução, implica refletir e buscar a compreensão do seu significado; talvez possamos, se de fato desejarmos, caminhar para uma mudança e, para tanto é preciso nos darmos conta, cada um de nós, de sua responsabilidade nisso; um prefeito, um juiz, um legislador, não constróem sozinhos e somente pelas próprias ações, uma sociedade menos desigual. Para nós, a desigualdade depende, não apenas da concordância de cada um de nós, em "ter" mais, ou menos, que o outro, mas da omissão de responsabilidade pessoal, para com a própria situação que a legitima.

No cotidiano, as coisas apenas começam a se desorganizar na direção de uma possível transformação; estão aí os Conselhos Tutelares, os Conselhos Municipais de Direitos da Criança e do Adolescente, os Fóruns de direitos da criança e do adolescente, entre outros; teremos, que refletir sobre nossas práticas nesses novos órgãos, ou novos papéis, (incluindo, por exemplo, o do Ministério Público, mais autônomo depois da 
Constituição/88). Essa reflexão é necessária, a fim de não reproduzirmos posturas centralizadoras, para manter nossas posições, ainda que pela causa, que nos indisponham a ouvir ao outro ou a nos avaliar, impedindo-nos a identificação de fragilidades e desacertos, necessária à construção de um novo caminho, que pode estar para além do que o ECA propõe.

Eventos que trouxeram a discussão dos 10 anos do ECA, como o de Ribeirão Preto, (ECA, 10 anos, 2000) e outros de São Carlos, como a I CONFERÊNCIA MUNICIPAL DOS DIREITOS DA CRIANÇA E DO ADOLESCENTE DE SÃO CARLOS (1999) e os "10 ANOS DE ESTATUTO DA CRIANCA E DO ADOIESCENTE" (2000), mostram que ainda defendemos posições assistencialistas, quando deixamos de investir esforços na formulação de políticas públicas e na discussão do orçamento público, limitando-nos à discussão da destinação de recursos para entidades assistenciais, projetos emergenciais ou especiais, para "administrar" ou "" socorrer" essa ou aquela "situação de risco" em que se encontram crianças e adolescentes, de acordo com seus tipos de atributo. Apesar da nova linguagem, "terceiro setor", continuamos justificando e dando como novo, o mesmo modelo e os mesmos tipos de instituição que o representam, como as ações das instituições da Igreja ou mesmo o voluntariado.

Mantemos o velho modelo, quando, enquanto Conselho Estadual dos Direitos da Criança e do Adolescente (CONDECA), nos esquivamos da discussão e da busca de mecanismos, para interferir na efetiva destinação dos recursos, do orçamento municipal e estadual, limitando-nos à ações e programas pontuais. Ou ainda, quando, enquanto Universidade, não nos dispomos a essa reflexão, ou a rever, rigorosa e criticamente, nossas ações, limitando-nos a reproduzir projetos, que continuam se alimentando desse mesmo sistema, seja através de práticas de estágio, seja a título de "novas intervenções ou "novos campos de trabalho", destituídos da vinculação com o poder público, onde se situam, ou de outra preocupação que não a de atender à necessidade clinica dos casos, ou do atendimento de pacientes, da demanda de saúde pelo velho modelo das necessidades individuais do sujeito.

O ECA pode abrir caminhos para a construção da reforma, para o início da transformação, da realidade, mas, não bastam ações individuais, desse ou daquele representante do poder público; é preciso a adesão de cada um; não bastam escolas, é 
preciso Conselhos de Direito e Tutelares; não bastam postos de saúde, é preciso Conselhos de Saúde; não bastam Conselhos, é preciso associar-se, "importar-se com"; dependemos da nossa organização, enquanto sociedade civil, mais que isso, é preciso o assumir da nossa cota individual de responsabilidade. Não bastam propostas de programas, é preciso deles, os programas; mas não bastam eles, é preciso mudança de atitude... ...aprender a ver a criança e o adolescente, sem descrédito, sem desvalor. É preciso criar, fazer a oportunidade, para que possam construir essa identidade, a de sujeito, que pensa, que sente, que tambem sabe e, portanto pode escolher. Não mais estamos falando da busca do "sujeito de direitos", mas sim da busca do "ser" e "do ser igual". Falamos de aprender a vê-los como pessoa e totalidade única e singular, como nós mesmos, sem tomá-los exclusivamente por atributos ou pela condição de discernimento sobre o que é certo ou errado, sobre o que deve ou não fazer. Falamos de buscar a possibilidade de ser.

Alguns de nós não concordam com esse caminho. Defendem a diminuição da maioridade penal, sustentando-se tanto em argumentos, que confundem imputabilidade e impunidade, quanto em critérios isolados, como a condição de discernimento do adolescente. Outros, reivindicam medidas das autoridades, defendendo a necessidade de prisões de segurança máxima (10 ANOS DE ESTATUTO DA CRIANÇA E DO ADOLESCENTE, 2000). Diante de posições como essas, é inevitável perguntar se seremos assim, tão rigorosos e implacáveis, em nossas reivindicações, quando diante dos "crimes" "adultos", representados por aqueles de nós, que faltam com seu dever? ...que se omitem, negligenciam a "proteção integral", a "prioridade absoluta", o "respeito à condição peculiar de pessoa em desenvolvimento", o "respeito à dignidade, liberdade e igualdade", às nossas crianças e adolescente, que a lei determina? Não teríamos, afinal, falhado, nós todos, sociedade civil e poder público, no nosso dever de proteção? Se não falhamos, que fazem elas nas ruas, se virando por conta própria? ...ou nos lixões, enfiadas no meio da imundície do mundo? ...ou nos cantos escondidos ou expostos e largados buscando as drogas? ...ou no meio da violência, matando e sendo mortos? Parece que temos sido rigorosos com eles, mas indulgentes conosco, ao cobrar nossa própria responsabilidade, diante de nossos deveres não cumpridos. 


\section{Acerca das dúvidas suscitadas...}

Primeiro, não há conhecimento sobre o real número de crianças e adolescentes, que passam anualmente pela Vara da Infầncia e da Juventude de São Carlos; o que se conhece é o número de situações (ou de processos, correspondente ao número de registros de eventos/situações inscritos nos Livros de Feitos do Cartório dessa Vara) envolvendo crianças e adolescentes, dos quais se chega ao número de casos, obtido, por sua vez, a pari ir do número de crianças ou adolescentes envolvidos em cada situação. Levantamos daí uma indagação: qual a refêrência utilizada por aqueles que se utilizam desse número para fazer declarações apontando o "aumento do número de crianças e adolescentes envolvidos na prática de crimes"? Considerando nossos resultados, essa afirmação carece de consistência.

Temos constatado que alguns de nós responsabilizam os ditos "menores" pelo aumento da criminalidade; referem-se aos crimes violentos, publicamente, sem apresentar qualquer fonte de referência, dando a perigosa impressão do uso irrefletido da generalização; não apresentam quaisquer dados, comparativos ou não, "medindo" o "aumento" da criminalidade, que parece mais servir de sinônimo para "aumento da violência", da qual também se fala, sem precisar o que é; também não se apresentam estatísticas/estudos mostrando "aumentos" no contingente de "crimes" praticados por adolescentes em relação a "crimes" praticados por adultos. Longe de informar as pessoas, isso ajuda a deformar o problema, reforçando a tese de que o problema está no adolescente e não na sociedade da qual ele é parte.

Outra dúvida se refere ao conceito de gravidade, utilizado nos processos. Não foi possível identificá-lo; mesmo empregado com relativa frequência, não é definido. Pode-se vê-lo aplicado, na forma de "gravidade presente", principalmente nas situações relativas a furtos repetidos e, também na forma de "ausência de gravidade", principalmente nos casos em que a sentença resultava no arquivamento ou na remissão. Esse, nos parece, é outro problema que merece reflexão; o emprego do termo "gravidade", frequentemente atribuída à conduta de adolescentes, pede maior cautela do que se tem observado existir.

Maior cautela seria também necessária ao emprego da "gravidade" para fazer declarações também acerca do "aumento da violência" atribuída aos adolescentes. Nem um (gravidade) nem outro (violência) dos termos são explicitados, mas são igualmente 
afirmados nos encontros, eventos e debates sobre a pratica infracional de adolescentes. Os dados encontrados, nesse estudo, relativamente à natureza das situações ditas infracionais, não confirmam esse tipo de tese, defendida por operadores, ou não, do direito (veja a frequência de situações ditas infracionais relativas a arma, agressão e homicídio).

Semelhantemente, parece-nos relativo esse nosso conceito, quando tomamos por grave uma série desses furtos ou desse tipo de coisa, que nomeamos "apropriação da coisa", "que é do outro" e relevamos a importância da ação de conduzir um veículo sem habilitação para tal, que põe em risco a integridade física, não apenas dos que transitam pelas vias públicas, mas do próprio adolescente; pelo que vimos, a expressiva maioria desses casos recebe advertência, ou remissão ou arquivamento, não ocorrendo outros tipos mais severos de medidas nesse tipo de infração; o mesmo não se aplica aos furtos, que atingem nossos patrimônios, em que se aplicam internações.

Outras questões que não se elucidam, embora presentes nos processos, são os procedimentos de uma investigação policial ou o mérito de algumas questões mais delicadas, como a "prova" (o que é prova? de que se constitui, afinal? ...o uso do B.O., por exemplo, como prova, se aplica?) ou a "autoria", por exemplo, no que diz respeito aos procedimentos para apurá-los.

Outra das nossas dúvidas, refere-se aos critérios de análise ou avaliação, estabelecidos em uma e outra das leis de referência utilizadas pelo Judiciário, para tomar uma decisão relativamente a cada caso dito infracional; a lei atual (BRASIL, 1990), faculta ao Ministério Público, conceder a remissão, pré-processual, "atendendo às circunstâncias e consequências do fato, ao contexto social, bem como à personalidade do adolescente e sua maior ou menor participação no ato infracional" (art. 126, ECA), assim como a anterior facultava à autoridade judiciária "considerando a personalidade do menor, seus antecedentes e as condições em que se encontre, bem como os motivos e as circunstâncias da ação", se "menor de 18 e maior de 14 anos", "proferir decisão de plano, entregando-o aos pais ou responsável, ouvido o Ministério Público" (art. 100, inc. IV), ou, se maior de 10 e menor de 14 anos, "proferir, motivadamente, decisão de plano, definindo a situação irregular do menor, ouvido o Ministério Público" (art. 101, par. único).

Foram muitas as vezes que, nos processos ditos infracionais dos anos de 1991 e 1996, encontramos a citação textual daquelas condições, na aplicação da remissão, mas restou 
conosco a impressão de que o procedimento é tomado na forma que mais se assemelha à formalidade, que obedece os ritos de um processo; se assim não é, entendendo que a avaliação daquelas condições, requer o emprego de conhecimentos de outras áreas técnicas, além da do direito, caberia indagar, de que forma o Judiciário, como está estruturado, operacionalizou essa orientação, uma vez que a Vara da Infância e da Juventude de São Carlos, conta no máximo com uma equipe técnica (com psicólogos e assistentes sociais), que, se em anos anteriores, como o de 1986, foi solicitada a intervir com alguma frequência (11,8\% dos casos ditos infracionais), nesses anos, 1991 e 1996, quase não participou (em 91, foi chamada a intervir em apenas $2,1 \%$ dos casos ditos infracionais e em 96 em somente $0,2 \%$ deles); além disso, não se encontram, nesses anos, 91 e 96 (como no de 86) registros de encaminhamentos para serviços da comunidade mesmo com a finalidade de obtenção dessa avaliação.

Finalmente, restam conosco dúvidas sobre o ECA, enquanto instrumento que vem para mudar a identidade e a condição de vida de crianças e adolescentes. Do nosso ponto de vista, não nos instrumentaliza para uma compreensão mais ampla do comportamento do adolescente, quando apesar dos avanços conceituais (Livro 1 do ECA), toma de "uma conduta", para qualificar um "ato infracional" (Livro 2 do ECA), utilizando como referência o Código Penal e a Lei de Contravenções Penais. E como afirmou NOGUEIRA (1991) "...não há diferença entre crime e ato infracional, pois ambos constituem condutas contrárias ao direito positivo, já que se situam na categoria do ilícito jurídico" ${ }^{12}$.

Daí, que a "aplicação integral" do ECA, reclamada por alguns, não nos parece a melhor resposta, porque mantém a utilização de instrumentos de natureza jurídica e caráter essencialmente penal, que não contemplam pressupostos do desenvolvimento humano, hoje conhecidos e necessários à compreensão da criança e do adolescente, enquanto pessoa, ou ser, em processo de formação. Talvez aí resida, de todas, a maior contradição da lei. Na coexistência de artigos, que, de um lado garantem-lhe o reconhecimento da condição de sujeito de direitos, de titular do direito à proteção integral, dada sua condição peculiar de pessoa em desenvolvimento e de outro permitem, por uma "conduta", a sua responsabilização e punição, com base nas mesmas referências penais, utilizadas para os

\footnotetext{
${ }^{12}$ Compreende-se aqui o "direito positivo" como sendo a lei, ou a norma legal e o "ilícito jurídico" como termo ou categoria abrangente que pode envolver vários tipos de ilíctos.
} 
que já atingiram a maioridade legal, a despeito da ciência já ter demonstrado, que são circunstâncias de várias naturezas, desde as pessoais/individuais às sócio-econômicas e culturais, que atuam na determinação dos nossos comportamentos. Exemplo oportuno da nossa "ambiguidade" é o envolvimento com as drogas; a ciência já reconheceu o uso e/ou abuso de drogas como situação, que requer intervenção clínica e assistência familiar; mais que isso, que a adesão a elas, longe de significar desvio de caráter, se dá por vias do encontro de um contexto desfavorável (falta de cç.'ições materiais, falta de oportunidades, falta de perspectivas, falta de assistência/atenção parental, enfïm, um conjunto de condições adversas à satisfação das necessidades básicas do ser, nos seus diferentes estágios de desenvolvimento) com um estado/periodo de fragilidade pessoal (situação de conflito, carência, insegurança, dúvida, angústia, sofrimento, dor...). A despeito disso, continuamos adotando, inclusive para o adolescente, a lei, que apesar de mudanças, apontadas por TELLES (1982), que impuseram tratamentos diferenciados para usuário (art.12, lei 6368/76) e traficante de drogas (art. 16, lei 6368/76), mantém o ultrapassado conceito, segundo o qual o usuário de drogas, embora visto como doente, a quem se impõe regime de tratamento e recuperação, continua sujeito à pena/punição (6 meses a 2 anos de detenção); embora o traficante, esteja sujeito à pena de 3 a 15 anos de reclusão, repressão e pena continuam se aplicando a ambos os casos.

Dessa forma, segundo nos parece hoje, havemos que reformular nossas referências sobre crianças e adolescentes em "situação de risco pessoal e social". A expressão não se presta à melhor formulação do problema ou à corroborar os pressupostos de uma nova concepção sobre crianças e adolescentes, proposta em parte no Estatuto; a expressão tem melhor correspondência com partes do Estatuto que reproduzem as mesmas velhas concepções, de situação problema, onde o alvo é a criança ou o adolescente e sua família, que se resolve com programas, centralizados nessa criança ou adolescente em sua família. Nesse sentido, não há avanços, ou contradição com os velhos modelos assistencialistas; a despeito de toda fundamentação sobre o direito ao direito, a lógica do Estatuto continua sendo a velha lógica, em que os situamos como "marginalızados", "excluídos", "desfiliados" ou "destituídos de cidadania".

Parece, afinal, manter-se a lógica da divisão (pobres e delinquentes) da institucionalização, da divisão entre "normais, habilitados, sãos, capacitados, morais" e 
"anormais, doentes, inadequados, incapacitados, carentes, não habilitados, imorais", entre "os que são problema" e "os que resolvem o problema", idéia que tem reforçado o corporativismo nas profissões e as posições de tutela, tratamento, atendimento e assistência, que por sua vez legitimam as posições de tutelado, tratado, atendido, assistido; mantém-se, na verdade, o pressuposto da condição de alguém a ser tutelado e disciplinado.

Mesmo a criação de Conselhos, responde limitadamente aos anseios de mudança, posto que constituídos por nós mesmos, reproduzem a mesma lógica. Para nós, não há mais justificativa para tomar a questão como "técnica", "social" ou "econômica", apenas. Carecemos do confronto com nossas próprias aspirações, com o modo de ser e estar no mundo; carecemos da reflexão acerca daquilo que consideramos nos dizer respeito ou não; carecemos saber de nós, se nos importamos com nossos pares; ou seremos primordialmente a nossa natureza individualista, que nos leva a olhar exclusivamente para os nossos próprios umbigos? É hora, talvez, de uma decisão acerca do que aspiramos... para nós e talvez para o outro. Se a nossa humanidade não nos despertou ainda, talvez a "falta" dela no outro, se traduza em violência capaz de nos despertar... mas que não seja para mais vingança contra o outro, mas, talvez, para uma tentativa de compreender o outro... quem sabe, até, sem julgamentos, preconceitos ou presunções a seu respeito.

\section{|||||||||Da nossa percepção acerca deste trabalho...}

Além da sustentação na literatura, nossas afirmações estão apoiadas nos dados encontrados nos processos; foram mais de 2000 processos analisados. São também o produto "contaminado" das percepções derivadas de nossas relações pessoais no cotidiano dos eventos e encontros voltados a tudo o que diz respeito às nossas crianças e adolescentes, nesse e em outros municípios, dos quais pudemos participar.

Essas percepções, devem, portanto, ser tomadas à luz das naturais limitações. Além disso os dados contidos nos processos refletem apenas parcialmente a realidade; não nos informam da sua totalidade, dando conta de apenas parte da situação; as versões ali registradas nem sempre correspondem às opiniões, posturas, posições de todos os participantes da situação (referímo-nos principalmente ao caso dos adolescentes envolvidos). Pudemos confirmar essa posição, por ocasião da participação no tribunal de júri, do acompanhamento de liberdade assistida, aplicada a adolescentes, nas relações externas à liberdade assistida, com esses adolescentes e com o orientador de liberdade 
assistida, nas relações com diversos operadores do direito, que ocupavam diferentes posições na hierarquia judiciária, enfim, por isso tudo, a despeito do número de processos lidos dar consistência às afirmações, nossa percepção é parcial (porque limitada) e contaminada/enviesada. Disso resulta constituir-se o trabalho não em descrição, mas em aproximação da realidade, daquelas situaçðes. Os dados dão informações, mas não sabemos de fato "o que aconteceu"; fazemos aproximações, compreensões parciais, portanto, da realidade. Como tudo que pensamos conhecer ou saber e de fato, não conhecemos ou sabemos. Conhecemos sim parcialmente, a realidade, a história e os fatos que a constituem e, do que sabemos, deduzimos, concluímos por uma dedução, que aquela é a realidade e assim a tomamos, supondo estar nos apropriando dela; mas, o que nos parece, é que não podemos, de fato, apreendê-la, senão apenas parcialmente, porque não vemos tudo e não vemos sem julgar, sem nos desvinçular daquilo que somos. Podemos ser objetivos, mas também a nossa objetividade sofrerá os efeitos do nosso próprio olhar... ...a despeito do quanto nos esforcemos para não sermos parciais, ainda não sabemos da neutralidade na ciência.

É oportuno lembrar que a consulta e estudo de textos de natureza jurídica ou legal, assim como as discussões com profissionais da área do Direito, para compreender as nuanças e peculiaridades da redação e das figuras jurídicas, cotejados, no cotidiano, com a leitura ou interpretação da lei pelos operadores ou não, do direito reforçam-nos a impressão da natureza ambígua da lei, ao mesmo tempo contudo, nos põem mais uma vez em dúvida acerca de nós mesmos. Talvez nós é que sofrendo os limites da parcialidade humana, variemos em nossas interpretações de acordo com as circunstâncias.

Interrompemos aqui este trabalho, deixando claro que muitas informações permanecem conosco, a despeito da sua importância; valendo-nos da leitura de BECKER (1993) percebemos que muitos dos nossos achados seriam valiosos no sentido de conferir talvez maior credibilidade às nossas conclusões ou mesmo de acrescê-las de outras tantas consideraç̃es. Entretanto, é preciso ponderar sobre o tipo de informação de que tratamos e considerar a delicada condição de responder pelo sigilo ético de uma pesquisa, quando nos vemos diante da possibilidade de identificação, tanto das crianças e adolescentes, como dos agentes envolvidos nesses processos/situações, por conta de muitos sinais aí presentes. Assim a decisão final é do pesquisador e optamos por não fazê-lo, ainda que com isso 
algumas de nossas conclusões possam resultar não suficientemente demonstradas, do ponto de vista de outros modelos de pesquisa.

Cada um certamente poderá fazer sua própria avaliação acerca dos dados apresentados, definindo o grau de confiança em que os tomará como evidências e decidirá particularmente pelo grau de credibilidade que dará às nossas conclusões.

Como qualquer outra, essa é uma pesquisa em que o conteúdo reflete o modo como o pesquisador concebe pesquisa e principalmente o modo como compreende o que antes tomou por problema a ser estudado. Diz do que ele acredita e, portanto, defende.

Fica o desejo, não de convencermos a ninguém, mas de talvez cruzarmos nosso caminho com aqueles que ao fazer a leitura deste trabalho, tenham aceitado o convite à reflexão e se aventurado a procurar outros caminhos que não os já percorridos. Talvez no esforço de cada um esteja a possibilidade de alcançarmos nossas crianças e adolescentes... ...no esforço de buscar olhar para elas apenas como são... ...crianças e adolescentes apenas... ...sem julgamentos... ...sem adjetivos discriminativos... ...sem intolerância... ...mas com o respeito, com a dignidade e com o amor, de que todos carecemos. Talvez, se pudermos fazê-lo, elas possam reciprocamente assim responder.

Inserimos aqui nosso último quadro; uma espécie de diagrama que mostra como está estruturado o ECA, relativamente às partes que o compðem. Além de permitir uma fácil visualização do todo, pode nos ajudar a perceber que a politica de atendimento antecede as medidas, apontando a necessidade de compreender que, longe ainda da sua principal proposição (mudança nas políticas públicas), diagnósticos acerca de seus supostos malefícios, ou da sua nenhuma serventia, certamente ficam comprometidos. 


\section{ECA - ESTATUTO DA CRIANÇA E DO ADOLESCENTE}

Títula 1

Disposiçóes Proliminares

LIVRO
PARTE
GERAL

GERAL [art. 1' 10 25]

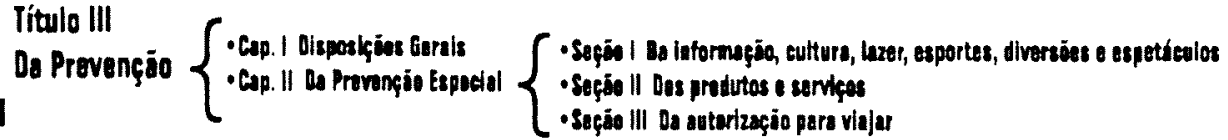

Títuloll C Cap. I Do diraito d vida a i saíde

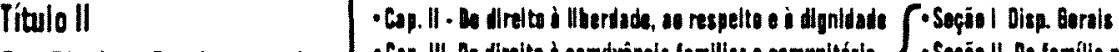

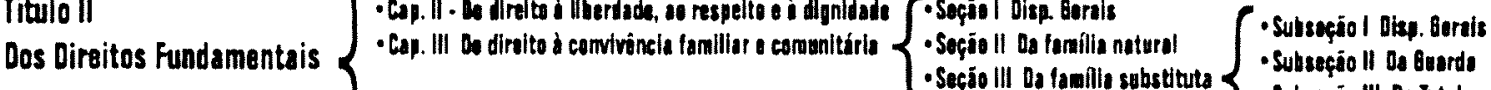

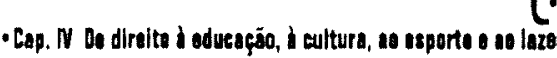

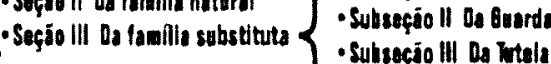

- Cas. V do diretto i profilssionalizagion a a protegia we trabalho

- Sulseçio ill Da intala

- Sultseçión N ua Noçäo

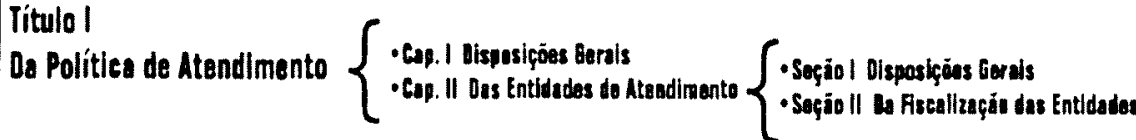

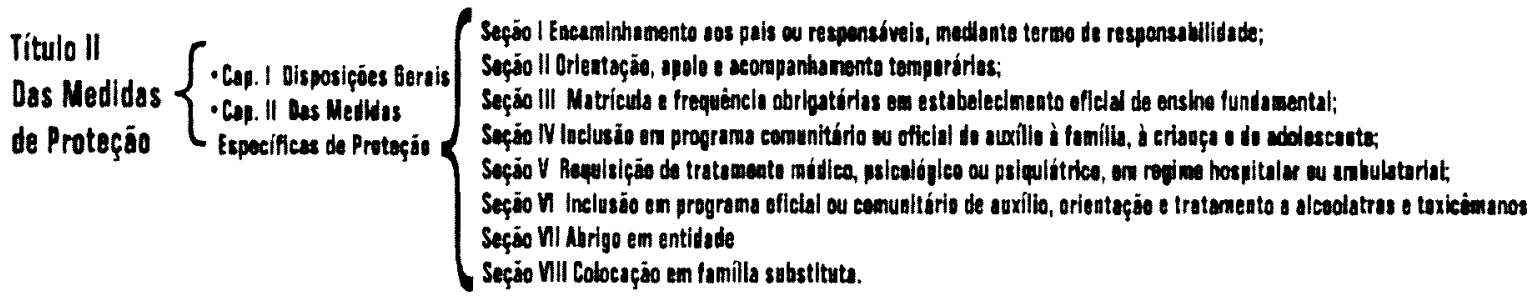

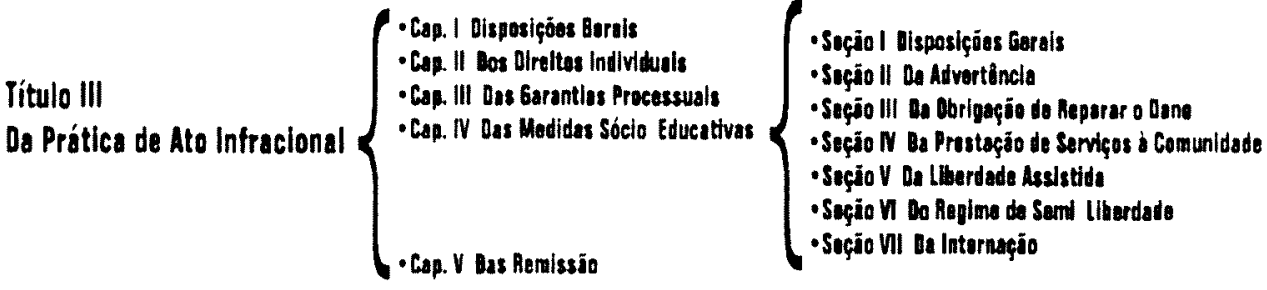

Título IV - Das Medidas Pertinentes aos Pais ou Responsável

\section{LIVRO
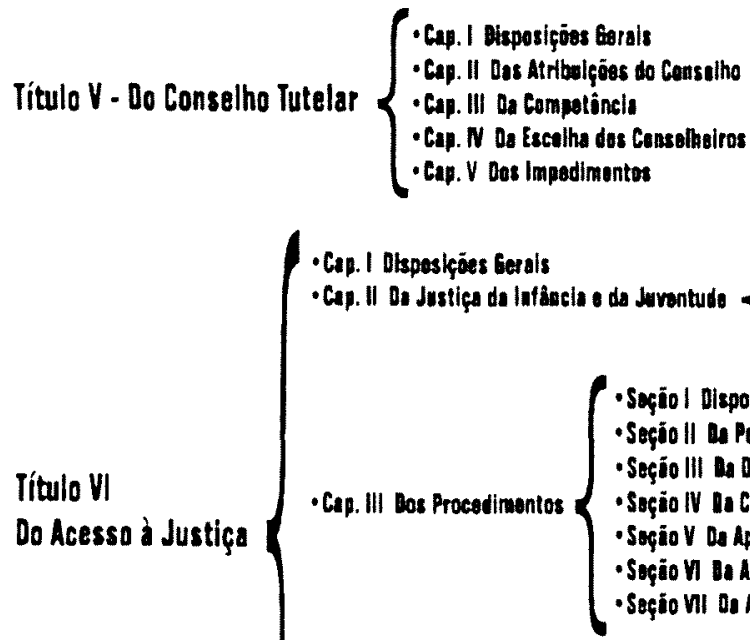

de Juventudio $\{$.

- Sefaia I Disposiçäes Gerak

- Seçio ll Bo Jula

- Cap. N loa Recunas

- Cap. V De Milastério Pibilico

- Cap. VI Bo Advorida

- Cap. VII Da Protoça Judieial dos Intoresses Individuals, gihusas ou Colativas

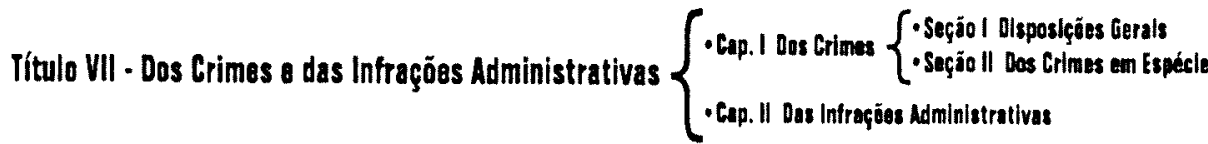




\section{Referências}

ABRAMO, P. Pesquisa em Ciências Sociais, In: SEDI, H. Pesquisa Social: projeto e planejamento. São Paulo: T. A. Queiroz; 1979. p.21-88.

Albergaria, J. Comentários ao Estatuto da Criança e do Adolescente. Rio de Janeiro: Aide, 1991.

ALVIM, M.R.B.; VALLADARES, L. P. Infầncia e Sociedade no Brasil: uma análise da literatura. BIB, 1988; 26: 3-37.

BARRETO, A. Políticas Sociais e Assistenciais Existentes. In: Anais do Seminário Criança e Adolescente em situação de risco: uma compreensão necessária; 1996 mar 19-23; Curitiba, Brasil. Curitiba: Instituto Municipal de Administração Pública; 1996. p. 23-33.

BECKER, H. S. Métodos de pesquisa em ciências sociais. Trad. de M Estevão e R Aguiar. São Paulo: Hucitec; 1993. Problemas de inferência e prova na observação participante; p. 47-64.

BECKER, H. S. Métodos de pesquisa em ciências sociais. Trad. de M Estevão e $R$ Aguiar. São Paulo: Hucitec; 1993. Evidências de trabalho de campo; p. 65-99.

BRASIL. Código Penal : Decreto Lei n. 2848 de 7 de dezembro de 1940. $25^{\mathrm{a}}$ ed. São Paulo: Saraiva; 1987. (Organização de textos, notas remissivas e indíces por Juarez de Oliveira).

BRASIL. Código de Menores: Lei n. 6697 de 10 de outubro de 1979. (Lex 1979, 63, p.786-803). São Paulo: Lex Edit.; 1979.

OK_BRASIL. [ECA] Estatuto da Criança e do Adolescente: Lei Federal n. 8069 de 13 de julho de 1990. São Carlos: UFSCar/CMDCA de São Carlos; 1993.

BRASIL. Lei das Contravenções Penais: Decreto Lei n. 3688 de 3 de outubro de 1941. 25a ed. São Paulo: Saraiva; 1987. (Organização de textos, notas remissivas e indices por Juarez de Oliveira). 
BRASIL. Lei n. 6368 de 21 de outubro de 1976. Dispõe sobre medidas de prevenção e repressão ao tráfico ilicito e uso indevido de substâncias entorpecentes ou que determinem dependência física ou psíquica, e dá outras providências. In: Código Penal: Organização de textos, notas remissivas e indices por Juarez de Oliveira; $25^{\mathrm{a}}$ ed. São Paulo: Saraiva; 1987.

CÂMARA MUNICIPAL DE SÃO PAULO. Comissão Especial de Estudos sobre a criança e o adolescente na Cidade de São Paulo. Relatório Final. São Paulo; 1996.

1 CONFERENCIA MUNICIPAL DOS DIREITOS DA CRIANÇA E DO ADOLESCENTE DE SÃO CARLOS: rompendo o pacto do silêncio; 1999 set 10; São Carlos, Brasil.

CONSELHO MUNICIPAL DOS DIREITOS DA CRIANÇA E DO ADOLESCENTE DE SÀO CARLOS. Prioridades para a ação. São Carlos; 1995. [Mimeo].

CURY, M.; GARRIDO, P. A; MARÇURA, J. N. Estatuto da Criança e do Adolescente Anotado. $2^{\text {a }}$ ed. São Paulo: Ed. Rev. dos Tribunais; 2000.

DIÁRIO DO CONGRESSO NACIONAL. Relatório final da Comissão Parlamentar de Inquérito destinada a apurar responsabilidades pela exploração e prostituição infanto-juvenil. Suplemento ao DCN n.155. Brasília, 21 out 1994. (Vol. I-IV).

DIMENSTEIN, G. Brasil tem 500 mil menores prostituídas. Folha de São Paulo. 1990 out 25 ; cad. C:1.

DIMENSTEIN, G. Meninas da noite: a prostituição de meninas escravas no Brasil. $12^{\mathrm{a}}$ ed. São Paulo: Ática; 1995.

DIMENSTEIN, G. O cidadx̆o de papel: a infância, a adolescência e os direitos humanos ho Brasil. $11^{\text {a }}$ ed. São Paulo: Ática; 1995a.

DIMENSTEIN, G. Tráfico de meninas é o retrato mais perfeito da crise brasileira. Folha de Săo Paulo. 1992, fev 14; cad. 1:7. 
DIMENSTEIN, G. Virgindade vai a leilão e alcança até US\$ 400. Folha de São Paulo. 1992 a fev 9 ; cad. $1: 9$.

DIMEnStein, G. Tráfico de drogas usa meninas-prostitutas. Folha de São Paulo. 1992b fev 7; cad. 1: 9 .

DROGAS, VIOLÊNCIA E EXCLUSÃO NA ADOLESCÊNCIA; 1996, nov 4-5; Curitiba, Brasil.

10 ANOS DO ESTATUTO DA CRIANÇA E DO ADOLESCENTE; 2000 mai 24-28; São Carlos, Brasil.

ECA 10 ANOS - Pensando os 10 anos do Estatuto da Criança e do Adolescente: projetando o futuro da infância e adolescência no Brasil; 2000 abr 28 e jun 29; Ribeirão Preto, Brasil.

EL-KHATIB, U. O desenvolvimento da criança. São Carlos; 1983. [Publicação Interna - Departamento de Terapia Ocupacional da UFSCar].

EL-KHATIB, U. O desenvolvimento da criança segundo diferentes abordagens. São Paulo; 1985. [Monografia de Especialização - Faculdades Associadas do Ipiranga].

EL-KHATIB, U. As dificuldades da pessoa portadora de deficiência física: quais são e onde estão. São Paulo; 1994 [Dissertação de Mestrado - Faculdade de Saúde Pública da USP].

EL-KHATIB, U. Sobre a criança e seu processo de desenvolvimento. Cad. Ter. Ocup. 1996; 5 (2): 111-120.

EL-KHATIB, U. Quando se trata de investigar "crianças e adolescentes em situação de risco pessoal e social...". Cad. Ter. Ocup. 1998; 7 (1): 1-13.

ENCONTRO REGIONAL DE CONSELHOS TUTELARES; 1996, mar 8-9; São Carlos, Brasil.

GRACIANI, M. S. S. A construção social da identidade de meninos(as) de rua. Rev . Bras. Cresc. Des. Hum. 1992; II(1): 147-153. 
GRACIANI, M. S. S. Educação Popular: A perspectiva da superação. In: Anais do Seminário Criança e Adolescente em situação de risco: uma compreensão necessária; 1996 mar 19-23; Curitiba, Brasil. Curitiba: Instituto Municipal de Administração Pública; 1996. p. 101-109.

GRUPO DE TRABALHO NACIONAL. Tribunal Nacional contra o trabalho Infantil. Brasília: Ed. FG. , 1995.

HUZAK, I.; AZEVEDO, J. Crianças de fibra. Rio de Janeiro: Ed. Paz e Terra; 1994.

JESUS, D. E. Lei das Contravenções Penais Anotada. $5^{\circ}$ ed. São Paulo: Saraiva; 1997.

JESUS, D. E. Código Penal Anotado. $7^{\text {a }}$ ed. São Paulo: Saraiva; 1997a.

MACHADO, A. L. R. Código de Menores Comentado. São Paulo: Saraiva; 1986.

MATEOS, S. B. Nossas crianças: a sucata do progresso. Rev. Atenção. 1992; 2: 8-16.

NOGUEIRA, P. L. Comentários ao Código de Menores. $2^{a}$ ed. São Paulo: Saraiva; 1985.

NOGUEIRA, P. L. Estatuto da Criança e do Adolescente Comentado: Lei n. 8069 de 13 de julho de 1990. São Paulo: Saraiva; 1991.

PACTO de Araraquara pela Erradicação do Trabalho Infantil. Araraquara; 1996 jun 14. [mimeo]

PACTO de Minas pela Educação. Belo Horizonte; 1994 jan 31. [mimeo]

PACTO do Bandeirantes pela Erradicação do Trabalho Infantil no Setor SucroAlcooleiro. São Paulo; 1996 abr 9. [mimeo]

PINHEIRO, P. S. A criança e o adolescente: compromisso social. In AZEVEDO, M. A.; GUERRA, V. N. A. Crianças vitimizadas: a síndrome do pequeno poder. São Paulo: Edit. Iglu; 1989. p.9-11. 
RELATÓRIOS DO CONSELHO TUTELAR DE SÃO CARLOS. 1994 - 2000. São Carlos (SP). [mimeo]

RIZZINI, I. et al. Brazil: A new concept of childhood. In BLANC, C. S. (coord.). Urban Children in distress: global predicaments and innovative strategies. Pennsylvania: UNICEF; 1994. p.55-99

ROSEMBERG, F. Estimativa de crianças e adolescentes em situação de rua na cidade de São Paulo. Cad. Pesq. 1994; 91: 30-45.

ROSEMBERG, F. O discurso sobre a criança de rua na década de 80. Cad. Pesq. 1993; 87: $71-81$.

SANTOS C. M. A. et al. Prostituição Infantil: considerações teóricas e observações sobre a realidade de Fortaleza. Rev. de Psicologia. 1989/1990: 7(1/2) e 8(1/2): 97-113.

SANTOS, H. O. Crianças espancadas. Campinas: Papirus; 1987.

SANTOS, H. O. Crianças esquecidas. Campinas: Pontes; 1995.

SÃo CARLOS tem bolsões de miséria. Folha de São Paulo. 1997 jun 22; cad 7:1.

Seminário Criança e Adolescente em Situação de Risco Pessoal e Social: uma compreensão necessária; 1996 mar 19-23; Curitiba, Brasil.

TELLES, C. Aspectos juridico-policiais da toxicomonia. In: SANCHEZ, A. M. T. et. al. Drogas e Drogados: o indivíduo, a família, a sociedade. São Paulo: EPU; 1982. p. 247-61.

TONIN, M. N. Análise Conjuntural da Realidade Mundial e Brasileira na Atualidade. In: Anais do Seminário Criança e Adolescente em situação de risco: uma compreensão necessária; 1996 mar 19-23; Curitiba, Brasil. Curitiba: Instituto Municipal de Administração Pública; 1996. p. 9-22. 


\section{Bibliografia Complementar}

ALBUQUERQUE, L. FEBEM tem mais envolvidos com droga. O Estado de São Paulo. 1996, ago 16; cad. C: 3.

ALVARENGA, A. T. Reflexões acerca da abordagem sociológica do crescimento e desenvolvimento da criança no campo da Saúde Pública: aspectos teóricometodológicos. Rev. Bras. Cresc. Des. Hum. 1991; 1:51-64.

ALVES, M. M. Violentos ou Violentados. São Paulo; 1994. [Texto apresentado no Fórum Estadual de Defesa dos Direitos da Criança e do Adolescente de São Paulo].

A situação da criança e do adolescente no Município de São Carlos; 1999 out 22; São Carlos (SP).

BARISON, M. S. Famílias envolvidas em situação de maus-tratos contra a criança e o adolescente. In MBES/CBIA. Família: ponto de chegada ou de partida? Rio de Janeiro; 1992. p. 39-43 (Cadernos CBIA, 4)

BARREIRA, M.C.R N.; BLANES, D.N.; CARVALHO, M.C.B. Cademos de Ação n. 2: Trabalhando Conselhos Tutelares. São Paulo: CBIAIEE-PUC; 1992.

BENITES, M. Crack: enfrentando o pesadelo. Rev. Cidade Nova. 1992; (6): 28-9.

BERGONSO, N. e SALVADOR, N. Drogas: o respeito a palavra do adolescente. São Carlos: Jaburu (s/d). (Série Adolescência)

BETO, F. Brincando nos campos da infância. O Estado de São Paulo. 1996, out, 9; cad. A:2.

BIAGgiO, A. M. B. Psicologia do desenvolvimento. $5^{\text {a }}$ ed. Petrópolis: Vozes; 1980.

BNDES/ASSOMA. Anais do Seminário sobre meninos de rua; 1988; Curitiba (PR).

BOND, L. S. La dolorosa realidad de los ninõs de la calle. Bol. Ofic. Sanit. Panam. $1993 ; 114(2): 97-104$. 
BRASIL, Código de Menores, Decreto lei n. 5083 de um de dezembro de 1926. Organização, índices e notas de Fernando H. Mendes de Almeida. São Paulo: Saraiva, 1955.

BRASIL, Constituiçåo Federal, promulgada em 05 de outubro de 1988: acompanhada de disposições anteriores, emendas constitucionais, emendas constitucionais de revisão, índices sistemático e alfabético-remissivo / organização, notas e índices por Juarez de Oliveira. São Paulo: Oliveira Mendes, 1998.

BRASIL. Lei no 7210 de 11 de julho de 1984 - Institui a Lei de Execução Penal. (Lex 1984, 68, p.627-650). São Paulo: Lex Edit.; 1984.

BUONCOMPAGNO, E. M.; SARMENTO, R. C. Sexualidade. In: Secretaria da Saúde do Estado de São Paulo. Comissão de Saúde do Adolescente. Adolescência e saúde. São Paulo: Paris Editorial; 1988. p. 97-101.

BYRNE, L Health risks of Rio's street children. BMJ. 1992; 304: 1459-60.

CAMPBELL, J. International debt, death squads, and children. BMJ. 1992; 305: 187.

CAMPOS, M. M. M. Questões sobre o caráter público dos convênios de atendimento à infância. Cad. Pesq. 1995; 95: 79-95.

CARDOSO, C.F.S.; BRIGNOLI, H.P. Os Métodos da História. Trad. J Maia. $3^{*}$ ed. Rio de Janeiro: Graal; 1983. p.123-34.

CARLINI, E. L. A. Preliminary Note: dangerous use of anticholinergic drugs in Brazil. Drug and alcohol Dependence. $1993 ; 32: 1-7$.

CARLINI, E. L. A. Uso ilícito de drogas lícitas pela nossa juventude. É um problema solúvel? Rev. Bras. Cres. Des. Hum. 1992; II (1): 129-43.

CARLINI-COTRIN B. e CARLINI, E. A. O consumo de solventes e outras drogas em crianças e adolescentes de baixa renda na Grande São Paulo. Parte II: Meninos de rua e menores internados. Rev. ABP-APAL. 1987; 9 (2): 69-77. 
CARLINI-COTRIN, B. Dados sobre o consumo de drogas por adolescentes no Brasil. Rev. ABP-APAL. 1987; 9 (3): 99-102.

CARVAlHO, M.C.B. (coord.) Cadernos de Ação n.3: Trabalhando Abrigos. São Paulo: CBIA/IEE-PUC; 1993.

CENTRO BRASILEIRO DE ANÁliSE E PLANEJAMENTO. A criança, o adolescente e a cidade: estudo sociológico sobre a marginalidade e a reintegração sociais do menor na cidade de São Paulo. São Paulo; 1972.

CIAADI. Relatório do Centro Integrado de Atendimento ao Adolescente Infrator. Curitiba; 1994. [mimeo]

CONSELHO MUNICIPAL DE DIREITOS DA CRIANÇA E DO ADOLESCENTE DE SANTOS. O cotidiano das crianças e adolescentes que trabalham estudam na cidade de Santos. Santos, 1995. [mimeo]

CORIAT, L. F. Maturação psicomotora no primeiro ano de vida da criança. Trad. de R J M Silva. São Paulo: Cortez \& Moraes; 1977.

COSTA, A. C. G. Falta vontade política para garantir os direitos de cidadania das crianças. Rev. Bras. Cres. Des. Hum. 1993; III(1): 17-23.

COSTA, A. C. G. O novo direito da criança e do adolescente no Brasil: o conteúdo e o processo das mudanças no panorama legal. In MAS/CBIA. Municipalização: possibilidade ou realidade. Rio de Janeiro; 1992. p. 11-14 (Cadernos CBIA, 2)

CUBELLS, F. Proteção ao menor. Trad. Y.S. Toledo. São Paulo: Loyola; 1992.

CURY, M. Os filhos do Brasil-I. Rev. Cidade Nova. 1991; (10): 4-6.

CURY, M. Os filhos do Brasil-II. Rev. Cidade Nova. 1992; (6): 12-14.

CUSMINSKY, M; OJEDA, E.N.S. Crecimiento y desarrollo: salud del niño y calidad de vida del adulto. In: Organización Panamericana de la Salud. Crecimiento y desarrollo: hechos y tendencias. Washington (DC): 1988; p.3-19. (Publicación Cientifica 510). 
DAL-ROSSO, S.; RESENDE, M. L. S. As condiçőes de emprego do menor trabalhador (comerás o pão com o suor de seu rosto). Thesaurus; 1986.

DANTAS, M. G. Dados de implantação dos Conselhos Estaduais e Municipais de Direitos da Criança e do Adolescente e Conselhos Tutelares. In MBES/CBIA. Familia: ponto de chegada ou de partida? Rio de Janeiro; 1992, p.67-69. (Cadernos CBIA, 4)

Delmanto, C. Código Penal Comentado. $3^{\mathrm{a}}$ ed. Rio de Janeiro: Renovar; 1991.

DIÁRIO OFICIAL DO ESTADO. Relatório da Comissão Especial de Inquérito sobre o problema do menor. São Paulo; 1980 set 30; p. 83-114.

EISENSTEIN, E.; SOUZA, R. P. (coords.) Situações de risco à saúde de crianças e adolescentes. Rio de Janeiro: Vozes/ CECIP/ CENESPA; 1993.

FAUSTO, A.; CERVINI, R. (Org). O trabalho e a rua: crianças e adolescentes no Brasil urbano dos anos 80. São Paulo: Cortez; 1991.

FEBEM registra recorde no número de internações. O Estado de São Paulo. 1996 out 30; cad. C: 4.

FERREIRA, N. T. Meninos de rua: um desafio para a escola. Rev. Em aberto. 1993; 53: 85-93.

FREIRE, P. O papel do educador. S. Paulo; 1987. [Mimeo reproduzindo Palestra Proferida no Centro Teotônio Vilela da FEBEM em 15 jan 1984, utilizado no II e III Curso de Seleção e Formação de Educadores para o Programa "Turma da Rua" pela Secretaria do Menor]

FUNDAÇÃO IBGE. Crianças \& Adolescentes: indicadores sociais. Rio de Janeiro; 1989. v. 3.

FUNDO SOCIAL DE SOLIDARIEDADE (Secretaria do Estado de São Paulo). Programa permanente de prevenção ao uso indevido de drogas: 2 anos de realizações. São Paulo [s/d; ano provável: 94] 
FUNDO SOCIAL DE SOLIDARIEDADE DO ESTADO DE SÃO PAULO. Direitos da criança e do adolescente. São Paulo: IMESP; 1993.

GAUDERER, E. C. Adolescência, os jovens e nós: uma visão pessoal: $1^{\circ}$ parte: um ser questionador . Jornal de Pediatria. 1986; 60(1/2): 57-65.

GAUDERER, E. C. Adolescência, os jovens e nós: uma visão pessoal: $2^{\circ}$ parte: um ser esquisito. Jornal de Pediatria. 1986; 61(2): 136-150.

GAUDERER, E. C. Adolescência, os jovens e nós: uma visão pessoal: $3^{\circ}$ parte: um ser em perigo. Jornal de Pediatria. 1986; 61(3): 213-218.

GAUDERER, E. C. Adolescência, os jovens e nós: uma visão pessoal: $4^{\circ}$ parte: um ser amável. Jornal de Pediatria. 1986; 61 (5/6 ): 337-346.

GAUDIANO, A. Reflexiones sobre las estadisticas de la infancia abandonada. Bol. Interam. del Nino. 1983; 219: 55-62.

GESELL, A. et al. Psicologia evolutiva de 1 a 16 anos. Buenos Aires: Paidós, 1975.

GeSEll, A.; AMATrudA, C. Diagnostico del desarrollo. Buenos Aires: Paidós, 1945.

GITSIO, F. Garotos levados para o SOS voltam às ruas. O Estado de São Paulo. 1996 out 31 ; cad. C: 4.

GITSIO, F. SOS enfrenta resistência de jovens nas ruas . O Estado de São Paulo. 1996 out 30; cad. C:4.

GONZALEZ, R. La salud mental y el desarrollo psicossocial del niño. In: Organización Panamericana de la Salud. Condiciones de salud del niño en las Américas. Washington (DC): 1979; p.81-88. (Publicación Cientifica 381).

GOUVEA, M.C.S. A criança da favela em seu mundo de cultura. Cad. Pesq. 1993; (86): 48-54. 
GRANDE São Paulo lidera consumo entre estudantes. O Estado de São Paulo. 1997 jan 5 ; cad. C:3.

GUIMARÃES, C. M. Estudo da desnutrição materna e da patologia da gestação sobre o crescimento do concepto e da criança no primeiro ano de vida. São Paulo; 1982. [Tese de Doutoramento - Faculdade de Saúde Pública da USP].

JUNQUEIRA, L. Abandonados. São Paulo: Ícone; 1986.

KNOBEL, M. Desenvolvimento psicológico. In: Secretaria da Saúde do Estado de São Paulo. Comissão de Saúde do Adolescente. Adolescência e saúde. São Paulo: Paris Editorial; 1988. p. 59-69.

KRITSCH, R. Direitos Humanos. O Estado de São Paulo. 1996 nov 17; cad. C: 1.

KRITSCH, R. Prostituição infantil cresce em Brasília. O Estado de São Paulo. 1996 nov 17 ; cad. C: 4 .

LEAL, G. Psicóloga tenta identificar futuros criminosos. O Estado de São Paulo. 1996 out 13 ; cad. C: 8.

LE BOULCH, J. O desenvolvimento psicomotor: do nascimento até 6anos. Trad. de AG Brizolara. $5^{\mathbf{a}}$ ed. Porto Alegre: Artes Médicas, 1982.

LEFEVRE, A. B. et al. Neurologia infantil: semiologia + clinica + tratamento. São Paulo: Sarvier, 1980.

LOGIE, D. The great exterminator of children. BMJ. 1992; 304: 1423-6.

LOMBARDI, R. Pesquisa traz perfil do assassino mirim. O Estado de São Paulo. 1996 dez 1 ; cad. C: 13.

LOMBARDI, R. Equipe especial combaterá drogas nas escolas. O Estado de Såo Paulo. 1997 jan 05; cad. C: 1.

MARTIN, M.V. et al. Sindrome del nino abandonado y maltratado. Arch. Arg. Ped. 1982; $80(6): 86-100$. 
MARTINS, S. B. E.; EBRAHIM, G. J. The female street children of Rio de Janeiro: a qualitative study of their backgrounds. J. Trop. Pediat. 1995; 41: 43-6.

MARTURANO, E. M. Um método para observação e análise do comportamento da criança em sala de aula. Psicologia. 1978; 4 (2): 37-73.

MEDEIROS, E. B. Drogas: prevenção hoje. Porto Ferreira: Conselho Municipal de Entorpecentes (COMEN), 1992.

MENINAS de rua são mais duras do que meninos. O Estado de S. Paulo. 1996 mai 6; cad. C: 1 .

MINAYO, M. C. S. (Coord). Bibliografia comentada da produção cientifica brasileira sobre violência e saúde. Centro Latino-Americano de Estudos sobre violência e saúde (CLAVES). Rio de Janeiro: ENSP; 1990.

Ministério da Justiça/ Secretaria dos Direitos Humanos/ Departamento da Criança/ Grupo de Trabalho (Portaria Ministerial 406/97). O atendimento sócioeducativo ao adolescente autor de ato infracional no Brasil: Avaliação e Proposições. Brasília; 1997. (Série Leia)

MONTEIRO, S. Infâncias perdidas. Jornal da ABRAPIA. 1993; 8: 4-5.

MORAES, E. S. O Fundo dos Direitos da Criança e do Adolescente: aspectos juridicos. In MAS/CBIA. Municipalização: possibilidade ou realidade. Rio de Janeiro; 1992. p.24-26. (Cadernos CBIA, 2)

MORATO, H. T. P.; ROCHA, M. C. Educador de rua: um desafio à abordagem centrada na pessoa? Bol. de Psicologia. 1992; 42 (96/97): 1-13.

NASCIMENTO, G. O céu por cobertor. Revista Isto é. 1995 (1364): 52-54.

OliveirA, Z. D. M. R. ; FERREIRA, M. C. R. Propostas para o atendimento em creches no Município de São Paulo: histórico de uma realidade. Cad. Pesq. 1986; 56 : 39- 65 .

O TRABALHO das crianças no mundo. O Correio da Unesco. 1991; (12): 37-8. 
OS MENINOS de rua. O Estado de S. Paulo. 1997 jan 10; cad. A: 3.

PACHECO, C. S. Adolescência: crise da consciência. Rev. de Psicanálise Integral. 1978; 1 (2): 34-39.

PEReirA, A. C. Crianças sem infância. O Estado de São Paulo. 1995 dez 21; cad. A: 4.

PEREIRA, I. (Coord). O Estatuto da Criança e do Adolescente e a Política de Assistência Social. São Paulo: SITRAEMFA/ CBIA; 1992. (Cadernos Populares, 9)

PEREIRA, I. (Coord). O Estatuto da Criança e do Adolescente e a questão da municipalização. São Paulo: SITRAEMFA/ CBIA; 1991. (Cadernos Populares, 5)

PEREIRA, I. (Coord). O Estatuto da Criança e do Adolescente e a Justiça da Infância e da Juventude. São Paulo: SITRAEMFA/ CBIA; 1991. (Cadernos Populares, 6)

PEREIRA, I. (Coord). O Estatuto da Criança e do Adolescente e a Questão do Delito. São Paulo: SITRAEMFA/ CBIA; 1991. (Cadernos Populares, 3)

PEREIRA, I. (Coord). O Estatuto da Criança e do Adolescente e as medidas sócioeducativas. São Paulo: SITRAEMFA/ CBIA; 1991. (Cadernos Populares, 7)

PEREIRA, I. (coord.). O Estatuto da Criança e do Adolescente e os trabalhadores da área da menoridade. São Paulo: SITRAEMFA/ CBIA; 1991. (Cadernos Populares, 4)

PEREIRA, I. Crianças/adolescentes: o trabalho. Fórum Estadual de Defesa dos Direitos da Criança e do Adolescente. São Paulo; 1994. [mimeo]

PEREIRA, P. Crianças são exploradas em pedreiras na Bahia. O Estado de São Paulo. 1996, dez 01; cad. A: 29.

PEREIRA, P. Crianças deixam escola para cortar sisal. O Estado de São Paulo. 1996, dez 03; cad. A: 20. 
PREFEITURA MUNICIPAL DE CURITIBA/IPPUC. Programas desenvolvidos pela Prefeitura Municipal de Curitiba para o atendimento às crianças e adolescentes na faixa de 0 à 17 anos. Curitiba; 1992. [mimeo]

RAPPAPORT, C. R. et al . Teorias do desenvolvimento: conceitos fundamentais. São Paulo: Pedagógica Universitária, 1981. V.1.

RENATO, C.; SOARES, R. Tráfico alicia cada vez mais menores do Rio. O Estado de São Paulo. 1996, set 15; cad. C: 5.

RICHARDS, M. P. M.; BERNAL, J. F. Um estudo acerca da interação mãe-bebê, utilizando o método de observação. In: BLURTON JONE, S. N. Estudos etológicos do comportamento da criança. São Paulo: Pioneira; 1972. ( Biblioteca Pioneira das Ciências Sociais).

ROGERS, C. As gangues de adolescentes. O Correio da Unesco. 1991; (12): 19-21.

ROMERO, F. A escola das ruas. O Correio da Unesco. 1991; (12): 16-8.

ROSA, A. C. S. et al. The street children of Recife: a study of their background. J. Trop. Pediat. 1992; 38: 34-40.

RUEGG, F. The International Catholic Child Bureau and drug abuse: contributions to drug abuse prevention by a non-governmental organization concerned with children. Bulletin on Narcotics. 1991; XLIII (1): 9-15.

RYDLE, C. Crianças de rua S. A. O Estado de S. Paulo. 1996, set 15; cad. C: 1-3.

SAITO, M. I. Necessidades Básicas de Saúde. In: Secretaria da Saúde do Estado de São Paulo. Comissão de Saúde do Adolescente. Adolescência e saúde. São Paulo: Paris Editorial; 1988. p. 77-85.

São Carlos. Decreto 034, de 22 de fevereiro de 1989. Institui o Conselho Municipal de Entorpecentes e dá outras providências.

São Paulo (Estado). Decreto n. 44.446, de 24 de novembro de 1999. Altera a vinculação da Fundação Estadual do Bem-Estar do Menor - FEBEM-SP, e dá 
outras providências. Lex: Legislação do Est. de S. Paulo; São Paulo: Edit. Lex; p. $1272-3$.

SCHNEIDER, L. Marginalidade e delinquência juvenil. São Paulo: Cortez; 1982.

SECRETARIA DE ESTADO DA CRIANÇA E ASSUNTOS DA FAMÍLIA/ FUNDO DE AÇÃo social do ParanÁ. Serviço de Atendimento Social: Programas Recepção e Triagem - Internação Provisória. SAS/ CIAADI. Curitiba; 1996 [mimeo]

SECRETARIA DO MENOR DO ESTADO DE SÃo PAUlO. Casa Aberta: 3 anos de experiência. São Paulo; 1990.

SECRETARIA MUNICIPAL DA CRIANÇA. Relatório de dados da Ação Emergencial - Atendimento e encaminhamento de crianças e adolescentes que se encontram no anel central da cidade de Curitiba. Curitiba; 1995.

SECRETARIA MUNICIPAL DO MENOR/IPPUC. Levantamento das entidades sociais que atuam com a criança e o adolescente carentes em Curitiba. Curitiba; 1989. [mimeo]

SEDA, E. A. A privação da liberdade como medida sócio-educativa para o infrator. Fórum Estadual de Defesa dos Direitos da Criança e do Adolescente. São Paulo; 1994. [mimeo]

SEGAL, U. A.; ASHTEKAR, A. Detection of intrafamilial child abuse: children at intake at a children's observation home in India. Child Abuse \& Neglect. 1994; 18 (11): 957-67.

SILVA, A.F.A. Imputabilidade penal aos 16 anos. Uma solução? Florianópolis: Ed. El-Shaddai; 1999. (Associação Brasileira dos Magistrados e Promotores de Justiça da Infầncia e da Juventude).

SILVA, A. S. et al. Observações sobre o universo mental das crianças de rua. Rev. ABP-APAL. 1991; 13 (3): 85-96. 
SILVA, J. L. P.; SARMENTO, R. C. Gravidez. In: Secretaria da Saúde do Estado de São Paulo. Comissão de Saúde do Adolescente. Adolescência e saúde. São Paulo: Paris editorial; 1988. p. 131-42.

SIQUEIRA. A. A. F. A interação entre crescimento e desenvolvimento. Rev. Bras. Cresc. Des. Hum. 1991; 1(2): 19-26.

SITRAEMFA/FEBEM. Diagnóstico da Fundação do Bem Estar do Menor: para onde caminha a FEBEM? São Paulo; 1996 [mimeo]

SITUAÇÃO da infância no Brasil. Cad. Terceiro Mundo. 1987; (99): 37-47.

STREET children and substance abuse. World Health Forum. 1993; 14: 434-5.

SUDBRACK, M. F. O.; COSTA, L. F. A contribuição da abordagem sistêmica no trabalho com familias sobre problemas com crianças e adolescentes. In MBES/CBIA. Família: ponto de chegada ou de partida? Rio de Janeiro; 1992, p.26-31. (Cadernos CBIA, 4)

TEIXEIRA, M. L. T. (Coord.) Liberdade Assistida: uma polêmica em aberto. São Paulo: IEE-PUC/ CBIA; 1994. (Série Defesa dos Direitos da Criança e do Adolescente, 1)

THOMAN, E. B. Changing views of the being and becoming of infant. THOMAN, E. (ed.) Origins of the infant social responsiveness. 1979. cap17. p.445-459.

TUFIK, S. Abuso de drogas. In: Secretaria da Saúde do Estado de São Paulo. Comissão de Saúde do Adolescente. Adolescência e saúde. São Paulo: Paris Editorial; 1988. p. 191-210.

UNICEF/ONU Encontro Mundial de Cúpula pela Criança: Declaração Mundial sobre a sobrevivência, a proteção e o desenvolvimento da criança e Plano de ação para implementação da Declaração Mundial sobre a sobrevivência, a proteção e o desenvolvimento da criança nos anos 90. Nações Unidas, Nova York; 1990. 
UNICEF. Situação mundial da infância. Complementado pelos estudos especiais do UNICEF 'Impacto da recessão sobre as crianças' e 'Ajuste com dimensão humana'. Brasilia: 1984.

UNICEF. Situação mundial da infância 1997. Brasilia: 1997.

UNICEF. Situação mundial da infância 2000. Brasília: 2000.

VARGAS, L.A. Contexto socioantropológico del crecimiento infantil. In: Organización Panamericana de la Salud. Crecimiento y desarrollo: hechos y tendencias. Washington (DC): 1988; p. 20-37. (Publicación Cientifica 510).

VOLPI, M. (Org.) O adolescente e o ato infracional. 2 ed. São Paulo: Cortez; 1997.

WILLIAMS, C. Who are "street children'? A hierarchy of street use and appropriate responses. Child Abuse \& Neglect. 1993; 17: 831-41.

I Fórum Regional do adolescente em situação de risco pessoal e social e em conflito com a lei, do Município de São Carlos; 1998 ago 7-8; São Carlos (SP). CMDCA/São Carlos.

I Seminário de Drogadição na Infância e Adolescência: conhecimento e reflexão sobre a amplitude do problema; 1996 out 17-18; São Carlos (SP) CMDCA/ São Carlos.

II Conferência Municipal dos Direitos da Criança e do Adolescente; 2001, jul 01; São Carlos (SP). 
ANEXOS 
Modelo 1 - Ficha para transcrição dos dados registrados no Livros de Feitos

\begin{tabular}{|c|c|c|c|c|c|c|}
\hline \multicolumn{2}{|l|}{ Dia Coleta: } & \multicolumn{2}{|c|}{ Fonte: } & \multicolumn{3}{|c|}{ Ficha $n^{\circ}$} \\
\hline $\begin{array}{c}N^{\circ} \text { Registro } \\
\text { no Livro }\end{array}$ & Sexo & Idade & $\begin{array}{l}\text { Registrado } \\
\text { como: }\end{array}$ & $\begin{array}{c}\text { Data } \\
\text { do } \\
\text { Fato }\end{array}$ & $\begin{array}{c}\text { Data } \\
\text { Ajuiza/o } \\
\text { Ação Penal }\end{array}$ & Finalização \\
\hline & & & & & & \\
\hline & & & & & & \\
\hline & & & & & & \\
\hline & & & & & & \\
\hline & & & & & & \\
\hline & & & & & & \\
\hline & & & & & & \\
\hline & & & & & & \\
\hline & & & & & & \\
\hline & & & & & & \\
\hline & & & & & & \\
\hline & & & & & & \\
\hline & & & & & & \\
\hline & & & & & & \\
\hline & & & & & & \\
\hline & & & & & & \\
\hline & & & & & & \\
\hline & & & & & & \\
\hline & & & & & & \\
\hline & & & & & & \\
\hline & & & & & & \\
\hline & & & & & & \\
\hline & & & & & & \\
\hline & & & & & & \\
\hline & & & & & & \\
\hline & & & & & & \\
\hline & & & & & & \\
\hline & & & & & & \\
\hline & & & & & & \\
\hline & & & & & & \\
\hline & & & & & & \\
\hline & & & & & & \\
\hline
\end{tabular}


Modelo n. 2 - Ficha para transcrição dos dados, por caso encontrado

\begin{tabular}{|c|c|c|c|c|c|c|c|c|c|c|c|c|c|c|c|c|c|c|c|c|c|c|c|c|c|c|c|}
\hline caso & liv & proc & $\begin{array}{l}a \\
n \\
0\end{array}$ & $\begin{array}{l}\mathrm{s} \\
\mathrm{e} \\
\mathrm{x}\end{array}$ & $\begin{array}{l}\mathrm{i} \\
\mathrm{d} \\
\mathrm{a}\end{array}$ & origem & $\begin{array}{l}\text { Natu } \\
\text { reza }\end{array}$ & Daap & $\begin{array}{l}c \\
p\end{array}$ & $\begin{array}{l}\text { fin. } \\
01\end{array}$ & $\begin{array}{l}\text { proc. } \\
01\end{array}$ & $\begin{array}{l}\text { data } \\
01\end{array}$ & $\begin{array}{l}\text { fin. } \\
02\end{array}$ & $\begin{array}{l}\text { proc. } \\
02\end{array}$ & \begin{tabular}{l|} 
data \\
02
\end{tabular} & $\begin{array}{l}\text { fin. } \\
03\end{array}$ & $\begin{array}{l}\text { proc. } \\
03\end{array}$ & $\begin{array}{l}\text { data } \\
03\end{array}$ & $\begin{array}{l}\text { fin } \\
04\end{array}$ & $\begin{array}{l}\text { proc. } \\
04\end{array}$ & $\begin{array}{l}\text { data } \\
04\end{array}$ & $\begin{array}{l}\text { fin } \\
05\end{array}$ & $\begin{array}{l}\text { Proc } \\
05\end{array}$ & $\begin{array}{l}\text { data } \\
05\end{array}$ & $\begin{array}{l}\text { fin } \\
06\end{array}$ & $\begin{array}{l}\text { proc } \\
06\end{array}$ & $\begin{array}{l}\text { Data } \\
06\end{array}$ \\
\hline & & & & & & & & & & & & & & & & & & & & & & & & & & & \\
\hline & & & & & & & & & & & & & & & & & & & & & & & & & & & \\
\hline & & & & & & & & & & & & & & & & & & & & & & & & & & & \\
\hline & & & & & & & & & & & & & & & & & & & & & & & & & & & \\
\hline & & & & & & & & & & & & & & & & & & & & & & & & & & & \\
\hline & & & & & & & & & & & & & & & & & & & & & & & & & & & \\
\hline & & & & & & & & & & & & & & & & & & & & & & & & & & & \\
\hline & & & & & & & & & & & & & & & & & & & & & & & & & & & \\
\hline & & & & & & & & & & & & & & & & & & & & & & & & & & & \\
\hline & & & & & & & & & & & & & & & & & & & & & & & & & & & \\
\hline & & & & & & & & & & & & & & & & & & & & & & & & & & & \\
\hline & & & & & & & & & & & & & & & & & & & & & & & & & & & \\
\hline & & & & & & & & & & & & & & & & & & & & & & & & & & & \\
\hline & & & & & & & & & & & & & & & & & & & & & & & & & & & \\
\hline
\end{tabular}

Esta ficha foi utilizada para todos os anos de estudo.

\section{LEGENDA}

$\mathrm{LIV}=\mathrm{n}^{\circ}$ do livro de feitos

$\mathrm{PROC}=$ número do processo

$\mathrm{SEX}=$ sexo

IDA $=$ idade

Daap $=$ data

$\mathrm{CP}=$ número de casos envolvidos

FIN= Finalização do Processo 
Modelo 3 Ficha para registro de leitura de processos

\begin{tabular}{|c|c|c|c|}
\hline $\begin{array}{l}\text { Data: } \\
\text { Início: }\end{array}$ & Térmi & & \\
\hline$N^{\circ}$ Processo & $\begin{array}{l}\mathrm{N}^{\circ} \\
\text { ordem }\end{array}$ & $N^{\circ}$ Processo & $\begin{array}{l}\mathrm{N}^{\circ} \\
\text { ordem }\end{array}$ \\
\hline & 001 & & 035 \\
\hline & 002 & & 036 \\
\hline & 003 & & 037 \\
\hline & 004 & & 038 \\
\hline & 005 & & 039 \\
\hline & 006 & & 040 \\
\hline & 007 & & 041 \\
\hline & 008 & & 042 \\
\hline & 009 & & 043 \\
\hline & 010 & & 044 \\
\hline & 011 & & 045 \\
\hline & 012 & & 046 \\
\hline & 013 & & 047 \\
\hline & 014 & & 048 \\
\hline & 015 & & 049 \\
\hline & 016 & & 050 \\
\hline & 017 & & 051 \\
\hline & 018 & & 052 \\
\hline & 019 & & 053 \\
\hline & 020 & & 054 \\
\hline & 021 & & 055 \\
\hline & 022 & & 056 \\
\hline & 023 & & 057 \\
\hline & 024 & & 058 \\
\hline & 025 & & 059 \\
\hline & 026 & & 060 \\
\hline & 027 & & 061 \\
\hline & 028 & & 062 \\
\hline & 029 & & 063 \\
\hline & 030 & & 064 \\
\hline & 031 & & 065 \\
\hline & 032 & & 066 \\
\hline & 033 & & 067 \\
\hline & 034 & & 068 \\
\hline
\end{tabular}

Total de horas:

Total de processos: 


\section{Modelo 4 - Questionário utilizado para digitação em Epi-info 5}

QES A Foi utilizado para os anos de 1984, 1985, 1987, 1988, 1989, 1990, 1992, 1993, 1994 e 1995.

CASO PROC _ ANO SEXO_ IDA NATGER_ DFAT CP FIN NOVO

GRUPIDAD

GRUPNA

QES B_Foi utilizado para os anos de 1986, 1991 e 1996.

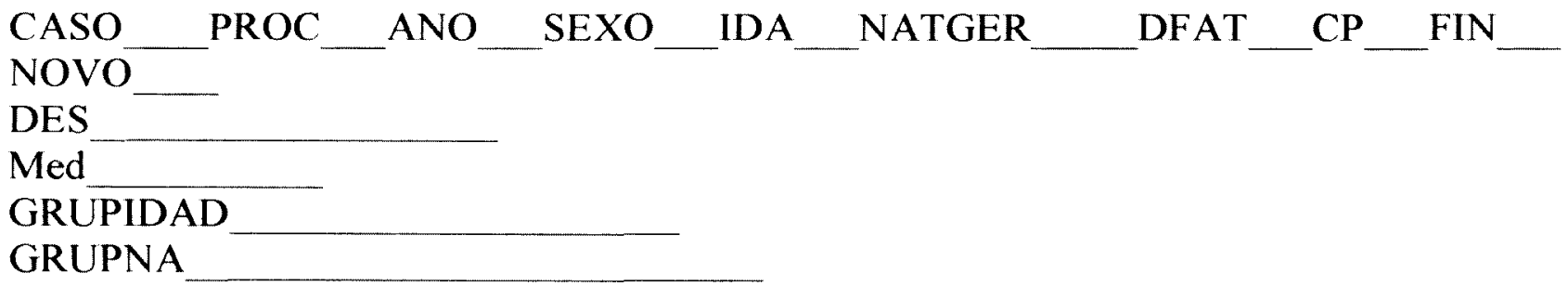

\section{LEGENDA:}

PROC $=$ número do processo

IDA $=$ idade

NATGER $=$ natureza

$\mathrm{DAFT}=$ data

$\mathrm{CP}=$ número de casos envolvidos

FIN $=$ Finalização do Processo

$\mathrm{NOVO}=$ número de casos com o mesmo processo

$\mathrm{DES}=$ descrição

Med $=$ medida

GRUPID= grupos de idades

GRUPNA = grupos de natureza 


\section{Anexo 5}

Tabela 01. Processos/situações atendidas pelo Fórum de São Carlos, em 1984, registradas no Cartório da Infância e da Juventude de São Carlos, distribuídas segundo as características identificadas: número de casos atendidos por situação, todas as naturezas encontradas e mês de registro da situação, no ano.

\begin{tabular}{|c|c|c|}
\hline CARACTERISTICAS & No. & $\%$ \\
\hline \multicolumn{3}{|l|}{ No. de Casos atendidos por situação } \\
\hline 1 criança/adolescente & 249 & 83.8 \\
\hline 2 crianças/adolescentes & 29 & 9.8 \\
\hline 3 e + crianças/adolescentes (até 7) & $19^{*}$ & 6.4 \\
\hline Total & $297^{* *}$ & 100.0 \\
\hline \multicolumn{3}{|l|}{ Natureza das situações } \\
\hline Sindicância & 168 & 56.2 \\
\hline Guarda & 67 & 22.4 \\
\hline Adoção & 17 & 5.7 \\
\hline Precatória & 14 & 4.7 \\
\hline Pedido de Internamento & 7 & 2.3 \\
\hline Pedido de providências & 6 & 2.0 \\
\hline Destituição de pátrio poder & 5 & 1.7 \\
\hline Abandono & 3 & 1.0 \\
\hline Colocação em familia substituta & 2 & 0.7 \\
\hline Pedido de alvará & 2 & 0.7 \\
\hline Pedido de registro & 2 & 0.7 \\
\hline Tutela & 2 & 0.7 \\
\hline Apreensão de menor & 1 & 0.3 \\
\hline Representação & 1 & 0.3 \\
\hline Autos de entrega & 1 & 0.3 \\
\hline Entrega de filho & 1 & 0.3 \\
\hline Total & 299 & 100.0 \\
\hline \multicolumn{3}{|l|}{ Mês de registro no ano } \\
\hline Outubro & 37 & 12.4 \\
\hline Maio & 35 & 11.7 \\
\hline Novembro & 33 & 11.0 \\
\hline Julho & 31 & 10.4 \\
\hline Junho & 31 & 10.4 \\
\hline Março & 28 & 9.4 \\
\hline Dezembro & 27 & 9.0 \\
\hline Setembro & 25 & 8.4 \\
\hline Abril & 23 & 7.7 \\
\hline Agosto & 22 & 7.4 \\
\hline Fevereiro & $7 * * *$ & 2.3 \\
\hline Total & 299 & 100.0 \\
\hline
\end{tabular}




\section{Anexo 6}

Tabela 02. Casos atendidos pelo Fórum de São Carlos, em 1984, registrados no Cartório da Infância e da Juventude de São Carlos, distribuídos segundo as características identificadas: sexo e idade.

\begin{tabular}{lcc}
\hline CARACTERISTICAS & No. & $\%$ \\
\hline Sexo & 267 & 70.8 \\
Masculino & 105 & 27.9 \\
Feminino & 5 & 1.3 \\
Sem informação & $377^{*}$ & 100.0 \\
Total & & \\
Idade & 4 & 1.1 \\
$<1$ & 16 & 4.2 \\
01 & 6 & 1.6 \\
02 & 13 & 3.4 \\
03 & 10 & 2.7 \\
04 & 5 & 1.3 \\
05 & 9 & 2.4 \\
06 & 10 & 2.7 \\
07 & 6 & 1.6 \\
08 & 6 & 1.6 \\
09 & 9 & 2.4 \\
10 & 8 & 2.1 \\
11 & $(102)$ & $(27.1)$ \\
$(<1$ a 11 anos $)$ & 15 & 4.0 \\
12 & 25 & 6.6 \\
13 & 28 & 7.4 \\
14 & 41 & 10.9 \\
15 & 50 & 13.3 \\
16 & 54 & 14.3 \\
17 & $(213)$ & $(56.5)$ \\
$(12$ a 17 anos) & 4 & 1.1 \\
18 e + & 58 & 15.4 \\
Sem informação & $377^{*}$ & 100.0 \\
\hline Total & & \\
\hline
\end{tabular}

*Excluidos 2 casos para os quais isto não se aplica. 


\section{Anexo 7}

Tabela 03. Processos/situações atendidas pelo Fórum de São Carlos, em 1985, registradas no Cartório da Infầncia e da Juventude de São Carlos, distribuídas segundo as características identificadas: número de casos atendidos por situação, todas as naturezas encontradas e mês de registro da situação, no ano.

\begin{tabular}{lcr}
\hline CARACTERiSTICAS & No. & $\%$ \\
\hline No. de Casos atendidos por situação & & \\
1 criança/adolescente & 336 & 79.4 \\
2 crianças/adolescentes & 55 & 13.0 \\
3 e + crianças/adolescentes (até 6) & $32 *$ & 7.6 \\
Total & 423 & 100.0 \\
Natureza das situaçães & & \\
Sindicância & 251 & 59.3 \\
Guarda & 80 & 18.9 \\
Precatória & 27 & 6.4 \\
Adoção & 20 & 4.7 \\
Pedido de Internamento & 11 & 2.6 \\
Pedido de providências & 7 & 1.7 \\
Destituição de pátrio poder & 7 & 1.7 \\
Abandono & 6 & 1.4 \\
Representação & 6 & 1.4 \\
Tutela & 5 & 1.2 \\
Pedido de registro & 1 & 0.2 \\
Entrega de filho & 1 & 0.2 \\
Colocação em família substituta & 1 & 0.2 \\
Total & 423 & 100.0 \\
Mês de registro no ano & & \\
Maio & 49 & 11.6 \\
Outubro & 48 & 11.3 \\
Setembro & 43 & 10.2 \\
Março & 38 & 9.0 \\
Novembro & 38 & 9.0 \\
Dezembro & 36 & 8.5 \\
Abril & 35 & 8.3 \\
Agosto & 33 & 7.8 \\
Janeiro & 29 & 6.9 \\
Julho & 27 & 6.4 \\
Junho & 26 & 6.1 \\
Fevereiro & 21 & 5.0 \\
\hline Total & 423 & 100.0 \\
\hline *(19 processos de 3, 7 de 4, 4 de 5 e 2 de 6) & & \\
\hline
\end{tabular}

*(19 processos de 3,7 de 4,4 de 5 e 2 de 6$)$ 


\section{Anexo 8}

Tabela 04. Casos atendidos pelo Fórum de São Carlos, em 1985, registrados no Cartório da Infância e da Juventude de São Carlos, distribuídos segundo as caracteristicas identificadas: sexo e idade.

\begin{tabular}{lcc}
\hline CARACTERISTICAS & No. & $\%$ \\
\hline Sexo & 390 & \\
Masculino & 162 & 69.3 \\
Feminino & 11 & 28.8 \\
Sem informação & 563 & 2.0 \\
Total & & 100.0 \\
Idade & 9 & \\
$<1$ & 19 & 1.6 \\
01 & 15 & 3.4 \\
02 & 12 & 2.7 \\
03 & 11 & 2.1 \\
04 & 13 & 2.0 \\
05 & 7 & 2.3 \\
06 & 15 & 1.2 \\
07 & 16 & 2.7 \\
08 & 7 & 2.8 \\
09 & 16 & 1.2 \\
10 & 14 & 2.8 \\
11 & $(154)$ & 2.5 \\
$(<1$ a 11 anos $)$ & 20 & $(27.4)$ \\
12 & 36 & 3.6 \\
13 & 68 & 6.4 \\
14 & 74 & 12.1 \\
15 & 75 & 13.1 \\
16 & 80 & 13.3 \\
17 & $(353)$ & 14.2 \\
$(12$ a 17 anos) & 2 & $(62.7)$ \\
18 e + & 54 & 0.4 \\
Sem informação & 563 & 9.6 \\
\hline Total & & 100.0 \\
\hline
\end{tabular}




\section{Anexo 9}

Tabela 05. Processos/situações atendidas pelo Fórum de São Carlos, em 1986, registradas no Cartório da Infância e da Juventude de São Carlos, distribuídas segundo as características identificadas: número de casos atendidos por situação, todas as naturezas encontradas e mês de registro da situação, no ano.

\begin{tabular}{|c|c|c|}
\hline CARACTERISTICAS & No. & $\%$ \\
\hline \multicolumn{3}{|l|}{ No. de Casos atendidos por situação } \\
\hline 1 criança/adolescente & 422 & 82.7 \\
\hline 2 crianças/adolescentes & 52 & 10.2 \\
\hline $3 \mathrm{e}+$ crianças/adolescentes (até 8 ) & $36^{*}$ & 7.1 \\
\hline Total & $510^{* *}$ & 100.0 \\
\hline \multicolumn{3}{|l|}{ Natureza das situações } \\
\hline Sindicância & 337 & 65.9 \\
\hline Guarda & 82 & 16.0 \\
\hline Adoção & 30 & 5.9 \\
\hline Precatória & 24 & 4.7 \\
\hline Pedido de providências & 11 & 2.1 \\
\hline Pedido de Internamento & 10 & 2.0 \\
\hline Destituição de pátrio poder & 6 & 1.2 \\
\hline Tutela & 5 & 1.0 \\
\hline Abandono & 3 & 0.6 \\
\hline Averiguação & 1 & 0.2 \\
\hline Auto de infração & 1 & 0.2 \\
\hline Devolução de filho. & 1 & 0.2 \\
\hline Pedido de alvará & 1 & 0.2 \\
\hline Total & 512 & 100.0 \\
\hline \multicolumn{3}{|l|}{ Mês de registro no ano } \\
\hline Agosto & 61 & 11.9 \\
\hline Abril & 51 & 10.0 \\
\hline Janeiro & 51 & 10.0 \\
\hline Fevereiro & 49 & 9.6 \\
\hline Julho & 48 & 9.4 \\
\hline Novembro & 41 & 8.0 \\
\hline Outubro & 41 & 8.0 \\
\hline Março & 36 & 7.0 \\
\hline Junho & 36 & 7.0 \\
\hline Maio & 34 & 6.6 \\
\hline Setembro & 34 & 6.6 \\
\hline Dezembro & 30 & 5.9 \\
\hline Total & 512 & 100.0 \\
\hline
\end{tabular}




\section{Anexo 10}

Tabela 06. Casos atendidos pelo Fórum de São Carlos, em 1986, registrados no Cartório da Infầncia e da Juventude de São Carlos, distribuídos segundo as características identificadas: sexo e idade.

\begin{tabular}{lcc}
\hline CARACTERISTICAS & No. & $\%$ \\
\hline Sexo & 453 & \\
Masculino & 196 & 68.8 \\
Feminino & 9 & 29.8 \\
Sem informação & $658^{*}$ & 1.4 \\
Total & & 100.0 \\
Idade & 15 & \\
$<1$ & 21 & 2.3 \\
01 & 18 & 3.2 \\
02 & 14 & 2.7 \\
03 & 14 & 2.1 \\
04 & 20 & 2.1 \\
05 & 14 & 3.0 \\
06 & 9 & 2.1 \\
07 & 12 & 1.4 \\
08 & 10 & 1.8 \\
09 & 18 & 1.5 \\
10 & 21 & 2.7 \\
11 & $(186)$ & 3.2 \\
$(<1$ a 11 anos $)$ & 28 & $(28.3)$ \\
12 & 34 & 4.2 \\
13 & 63 & 5.2 \\
14 & 78 & 9.6 \\
15 & 100 & 11.8 \\
16 & 104 & 15.2 \\
17 & $(407)$ & 15.8 \\
(12 a 17 anos) & 5 & $(61.8)$ \\
18 e + & 60 & 0.8 \\
sem informação & $658^{*}$ & 9.1 \\
\hline Total & & 100.0 \\
\hline
\end{tabular}

* Excluídos 2 casos, para os quais isto não se aplica. 


\section{Anexo 11}

Tabela 07. Processos/situações atendidas pelo Fórum de São Carlos, em 1987, registradas no Cartório da Infầncia e da Juventude de São Carlos, distribuídas segundo as caracteristicas identificadas: número de casos atendidos por situação, todas as naturezas encontradas e mês de registro da situação, no ano.

\begin{tabular}{|c|c|c|}
\hline CARACTERISTICAS & No. & $\%$ \\
\hline \multicolumn{3}{|l|}{ No. de Casos atendidos por situação } \\
\hline 1 criança/adolescente & 453 & 84.7 \\
\hline 2 crianças/adolescentes & 56 & 10.5 \\
\hline 3 e + crianças/adolescentes (até 5 ) & $26^{*}$ & 4.8 \\
\hline Total & 535 & 100.0 \\
\hline \multicolumn{3}{|l|}{ Natureza das situações } \\
\hline Sindicância & 317 & 59.3 \\
\hline Guarda & 107 & 20.0 \\
\hline Precatória & 42 & 7.9 \\
\hline Adoção & 30 & 5.6 \\
\hline Pedido de providências & 18 & 3.4 \\
\hline Abandono & 7 & 1.3 \\
\hline Pedido de internamento & 6 & 1.1 \\
\hline Destituição de pátrio poder & 2 & 0.4 \\
\hline Tutela & 2 & 0.4 \\
\hline Representação & 1 & 0.2 \\
\hline Apreensão de menor & 1 & 0.2 \\
\hline Averiguação & 1 & 0.2 \\
\hline Abrigo & 1 & 0.2 \\
\hline Total & 535 & 100.0 \\
\hline \multicolumn{3}{|l|}{ Mês de registro no ano } \\
\hline Outubro & 57 & 10.7 \\
\hline Novembro & 53 & 9.9 \\
\hline Abril & 52 & 9.7 \\
\hline Fevereiro & 49 & 9.2 \\
\hline Setembro & 48 & 9.0 \\
\hline Dezembro & 46 & 8.6 \\
\hline Junho & 46 & 8.6 \\
\hline Março & 43 & 8.0 \\
\hline Julho & 40 & 7.5 \\
\hline Janeiro & 35 & 6.5 \\
\hline Agosto & 33 & 6.2 \\
\hline Maio & 33 & 6.2 \\
\hline Total & 535 & 100.0 \\
\hline
\end{tabular}


Anexo 12

Tabela 08. Casos atendidos pelo Fórum de São Carlos, em 1987, registrados no Cartório da Infância e da Juventude de São Carlos, distribuídos segundo as características identificadas: sexo e idade.

\begin{tabular}{|c|c|c|}
\hline CARACTERISTICAS & No. & $\%$ \\
\hline \multicolumn{3}{|l|}{ Sexo } \\
\hline Masculino & 470 & 72.0 \\
\hline Feminino & 179 & 27.4 \\
\hline Sem informação & 4 & 0.6 \\
\hline Total & 653 & 100.0 \\
\hline \multicolumn{3}{|l|}{ Idade } \\
\hline$<1$ & 14 & 2.1 \\
\hline 01 & 22 & 3.4 \\
\hline 02 & 17 & 2.6 \\
\hline 03 & 13 & 2.0 \\
\hline 04 & 15 & 2.3 \\
\hline 05 & 15 & 2.3 \\
\hline 06 & 13 & 2.0 \\
\hline 07 & 15 & 2.3 \\
\hline 08 & 15 & 2.3 \\
\hline 09 & 12 & 1.8 \\
\hline 10 & 12 & 1.8 \\
\hline 11 & 15 & 2.3 \\
\hline ( $<1$ a 11 anos ) & (178) & $(27.3)$ \\
\hline 12 & 22 & 3.4 \\
\hline 13 & 36 & 5.5 \\
\hline 14 & 31 & 4.7 \\
\hline 15 & 59 & 9.0 \\
\hline 16 & 123 & 18.8 \\
\hline 17 & 122 & 18.7 \\
\hline (12 a 17 anos) & (393) & $(60.2)$ \\
\hline $18 e+$ & 5 & 0.8 \\
\hline sem informação & $77^{*}$ & 11.7 \\
\hline Total & 653 & 100.0 \\
\hline
\end{tabular}




\section{Anexo 13}

Tabela 09. Processos/situações atendidas pelo Fórum de São Carlos, em 1988, registradas no Cartório da Infância e da Juventude de São Carlos, distribuídas segundo as características identificadas: número de casos atendidos por situação, todas as naturezas encontradas e mês de registro da situação, no ano.

\begin{tabular}{|c|c|c|}
\hline CARACTERISTICAS & No. & $\%$ \\
\hline \multicolumn{3}{|l|}{ No. de Casos atendidos por situação } \\
\hline 1 crianca/adolescente & 391 & 81.6 \\
\hline 2 crianças/adolescentes & 52 & 10.9 \\
\hline 3 e + crianças/adolescentes (ate 7 ) & $36^{*}$ & 7.5 \\
\hline Total & 479 & 100.0 \\
\hline \multicolumn{3}{|l|}{ Natureza das situações } \\
\hline Sindicância & 326 & 68.1 \\
\hline Guarda & 54 & 11.3 \\
\hline Precatória & 33 & 6.9 \\
\hline Adoção & 27 & 5.6 \\
\hline Pedido de providências & 17 & 3.5 \\
\hline Abandono & 9 & 1.9 \\
\hline Pedido de Internamento & 7 & 1.5 \\
\hline Tutela & 2 & 0.4 \\
\hline Destituição de pátrio poder & 1 & 0.2 \\
\hline Fuga de menor & 1 & 0.2 \\
\hline Autorização para viagem $\mathrm{p} / \mathrm{o}$ exterior & 1 & 0.2 \\
\hline Menor em situação irregular & 1 & 0.2 \\
\hline Total & 479 & 100.0 \\
\hline \multicolumn{3}{|l|}{ Mês de registro no ano } \\
\hline Dezembro & 54 & 11.3 \\
\hline Maio & 44 & 9.2 \\
\hline Fevereiro & 44 & 9.2 \\
\hline Março & 43 & 9.0 \\
\hline Outubro & 43 & 9.0 \\
\hline Agosto & 42 & 8.8 \\
\hline Setembro & 41 & 8.6 \\
\hline Julho & 41 & 8.6 \\
\hline Junho & 40 & 8.4 \\
\hline Novembro & 31 & 6.5 \\
\hline Janeiro & 29 & 6.1 \\
\hline Abril & 27 & 5.6 \\
\hline Total & 479 & 100.0 \\
\hline
\end{tabular}

*(23 processos de 3,5 de 4,5 de 5,2 de 6 e 1 de 7$)$ 


\section{Anexo 14}

Tabela 10. Casos atendidos pelo Fórum de São Carlos, em 1988, registrados no Cartório da Infância e da Juventude de São Carlos, distribuídos segundo as características identificadas: sexo e idade.

\begin{tabular}{lcc}
\hline CARACTERISTICAS & No. & $\%$ \\
\hline Sexo & 486 & 77.4 \\
Masculino & 128 & 20.4 \\
Feminino & 14 & 2.2 \\
sem informação & 628 & 100.0 \\
Total & & \\
Idade & 5 & 0.8 \\
$<1$ & 16 & 2.5 \\
01 & 10 & 1.6 \\
02 & 16 & 2.5 \\
03 & 8 & 1.3 \\
04 & 12 & 1.9 \\
05 & 9 & 1.4 \\
06 & 4 & 0.6 \\
07 & 12 & 1.9 \\
08 & 12 & 1.9 \\
09 & 24 & 3.8 \\
10 & 21 & 3.3 \\
11 & $(149)$ & $(23.7)$ \\
$(<1$ a 11 anos $)$ & 36 & 5.7 \\
12 & 53 & 8.4 \\
13 & 76 & 12.1 \\
14 & 55 & 8.8 \\
15 & 89 & 14.2 \\
16 & 105 & 16.7 \\
17 & $(414)$ & $(65.9)$ \\
(12 a 17 anos) & 4 & 0.6 \\
18 e + & $61^{*}$ & 9.8 \\
Sem informação & 628 & 100.0 \\
\hline Total & & \\
\hline (60 nc, 1 ni) & & \\
\hline & & \\
\hline & &
\end{tabular}




\section{Anexo 15}

Tabela 11. Processos/situações atendidas pelo Fórum de São Carlos, em 1989, registradas no Cartório da Infância e da Juventude de São Carlos, distribuidas segundo as características identificadas: número de casos atendidos por situação, todas as naturezas encontradas e mês de registro da situação, no ano.

\begin{tabular}{lrr}
\hline CARACTERISTICAS & No. & $\%$ \\
\hline No. de Casos atendidos por situação & & \\
1 criança/adolescente & 515 & 82.1 \\
2 crianças/adolescentes & 70 & 11.2 \\
3 e + crianças/adolescentes (até 8) & $42^{*}$ & 6.7 \\
Total & 627 & 100.0 \\
Natureza das situações & & \\
Sindicância & 469 & 74.8 \\
Guarda & 48 & 7.7 \\
Precatória & 47 & 7.5 \\
Adoção & 32 & 5.1 \\
Pedido de providências & 14 & 2.2 \\
Pedido de Internamento & 8 & 1.3 \\
Pedido de autorização para viagem & 4 & 0.6 \\
Entrega de filho & 2 & 0.3 \\
Abrigo & 2 & 0.3 \\
Tutela & 1 & 0.2 \\
Total & 627 & 100.0 \\
Mês de registro no ano & & \\
Agosto & 69 & 11.0 \\
Maio & 64 & 10.2 \\
Março & 64 & 10.2 \\
Dezembro & 55 & 8.8 \\
Novembro & 53 & 8.5 \\
Abril & 52 & 8.1 \\
Janeiro & 51 & 8.0 \\
Setembro & 50 & 7.2 \\
Fevereiro & 45 & 7.0 \\
Julho & 44 & 6.5 \\
Outubro & 41 & 6.2 \\
Junho & 39 & 100.0 \\
\hline Total & 627 & \\
*(28 processos de 3, 5 de 4, 7 de 5, 1 de 6 e 1 de 8) & \\
& &
\end{tabular}




\section{Anexo 16}

Tabela 12. Casos atendidos pelo Fórum de São Carlos, em 1989, registrados no Cartório da Infância e da Juventude de São Carlos, distribuídos segundo as caracteristicas identificadas: sexo e idade.

\begin{tabular}{lcc}
\hline CARACTERÍSTICAS & No. & $\%$ \\
\hline Sexo & 609 & \\
Masculino & 170 & 75.4 \\
Feminino & 29 & 21.0 \\
Sem informação & 808 & 3.6 \\
Total & & 100.0 \\
Idade & 1 & \\
$<1$ & 12 & 0.1 \\
01 & 11 & 1.5 \\
02 & 10 & 1.4 \\
03 & 13 & 1.2 \\
04 & 3 & 1.6 \\
05 & 5 & 0.4 \\
06 & 12 & 0.6 \\
07 & 4 & 1.5 \\
08 & 5 & 0.5 \\
09 & 12 & 0.6 \\
10 & 28 & 1.5 \\
11 & $(116)$ & 3.5 \\
(<1 a 11 anos $)$ & 27 & $(14.4)$ \\
12 & 44 & 3.3 \\
13 & 97 & 5.4 \\
14 & 111 & 12.0 \\
15 & 146 & 13.7 \\
16 & 161 & 18.1 \\
17 & $(586)$ & 19.9 \\
(12 a 17 anos) & 4 & $(72.5)$ \\
18 e + & $102^{*}$ & 0.5 \\
Sem informação & 808 & 12.6 \\
\hline Total & & 100.0 \\
\hline *99 nc, 3 nl) & & \\
\hline & & \\
\hline & &
\end{tabular}




\section{Anexo 17}

Tabela 13. Processos/situações atendidas pelo Fórum de São Carlos, em 1990, registradas no Cartório da Infância e da Juventude de São Carlos, distribuídas segundo as características identificadas: número de casos atendidos por situação, todas as naturezas encontradas e mês de registro da situação, no ano.

\begin{tabular}{lcr}
\hline CARACTERISTICAS & No. & $\%$ \\
\hline No. de Casos atendidos por situação & & \\
1 criança/adolescente & 598 & 81.2 \\
2 crianças/adolescentes & 94 & 12.8 \\
3 e + crianças/adolescentes (até 10) & $44^{*}$ & 6.0 \\
Total & $736^{* *}$ & 100.0 \\
Natureza das situações & & \\
Sindicância & 486 & 65.9 \\
Adoção & 47 & 6.4 \\
Precatória & 46 & 6.2 \\
Guarda & 46 & 6.2 \\
Proc. verificatório de criança/ adolescente & 40 & 5.4 \\
Apur. de ato infracional de adolescente & 23 & 3.1 \\
Pedido de providências & 21 & 2.8 \\
Abrigo & 8 & 1.1 \\
Pedido de Internamento & 6 & 0.8 \\
Pedido de autorização para trabalho & 4 & 0.5 \\
Pedido de autorização para viagem & 3 & 0.4 \\
Entrega de filho & 2 & 0.3 \\
Autorização p/ viagem p/ o exterior & 1 & 0.1 \\
Atestado & 1 & 0.1 \\
Auto de infração & 1 & 0.1 \\
Diretrizes do Juizado para internação & 1 & 0.1 \\
Pedido de registro & 1 & 0.1 \\
Tutela & 1 & 0.1 \\
Total & 738 & 100.0 \\
Mês de registro no ano & & \\
Outubro & 102 & 13.8 \\
Novembro & 91 & 12.3 \\
Julho & 68 & 9.2 \\
Setembro & 67 & 9.1 \\
Abril & 65 & 8.8 \\
Março & 65 & 8.8 \\
Dezembro & 62 & 8.4 \\
Agosto & 61 & 6.6 \\
Janeiro & 49 & 5.0 \\
Junho & 37 & 4.9 \\
Fevereiro & 36 & 4.7 \\
Maio & 738 & \\
\hline Total & & \\
\hline (26 processos de & & \\
\hline
\end{tabular}

*(26 processos de 3,10 de 4,5 de 5,1 de 6 e 2 de 10 ).

**Excluídos 2 casos, para os quais isto não se aplica: 1 diretrizes do juizado, 1 auto de infração. 


\section{Anexo 18}

Tabela 14. Casos atendidos pelo Fórum de São Carlos, em 1990, registrados no Cartório da Infância e da Juventude de São Carlos, distribuídos segundo as características identificadas: sexo e idade.

\begin{tabular}{|c|c|c|}
\hline CARACTERÍSTICAS & No. & $\%$ \\
\hline \multicolumn{3}{|l|}{ Sexo } \\
\hline Masculino & 721 & 76.3 \\
\hline Feminino & 204 & 21.6 \\
\hline Sem informação & $20 * *$ & 2.1 \\
\hline Total & $945^{*}$ & 100.0 \\
\hline \multicolumn{3}{|l|}{ Idade } \\
\hline$<1$ & 13 & 1.4 \\
\hline 01 & 23 & 2.4 \\
\hline 02 & 10 & 1.1 \\
\hline 03 & 7 & 0.7 \\
\hline 04 & 9 & 0.9 \\
\hline 05 & 8 & 0.8 \\
\hline 06 & 7 & 0.7 \\
\hline 07 & 20 & 2.1 \\
\hline 08 & 10 & 1.1 \\
\hline 09 & 15 & 1.6 \\
\hline 10 & 23 & 2.4 \\
\hline 11 & 18 & $\begin{array}{l}1.9 \\
(172)\end{array}$ \\
\hline 12 & 37 & 3.9 \\
\hline 13 & 58 & 6.1 \\
\hline 14 & 86 & 9.1 \\
\hline 15 & 145 & 15.3 \\
\hline 16 & 182 & 19.3 \\
\hline 17 & 164 & 17.3 \\
\hline (12 a 17 anos) & $(672)$ & (71.1) \\
\hline $18 \mathrm{e}+$ & 3 & 0.3 \\
\hline sem informação & $107^{* * *}$ & 11.3 \\
\hline Total & $945^{*}$ & 100.0 \\
\hline
\end{tabular}

*Excluídos 2 casos, para os quais isto não se aplica: 1 aui, 1dji.

**(16 nc, $4 \mathrm{ni})$

*** (102 nc, $5 \mathrm{ni})$ 


\section{Anexo 19}

Tabela 15. Processos/situações atendidas pelo Fórum de São Carlos, em 1991, registradas no Cartório da Infância e da Juventude de São Carlos, distribuídas segundo as características identificadas: número de casos atendidos por situação, todas as naturezas encontradas e mês de registro da situação, no ano.

\begin{tabular}{|c|c|c|}
\hline CARACTERÍSTICAS & No. & $\%$ \\
\hline \multicolumn{3}{|l|}{ No. de Casos atendidos por situação } \\
\hline 1 criança/adolescente & 635 & 80.2 \\
\hline 2 crianças/adolescentes & 105 & 13.2 \\
\hline 3 e + crianças/adolescentes (até 5) & $52 * *$ & 6.6 \\
\hline Total & $792^{*}$ & 100.0 \\
\hline \multicolumn{3}{|l|}{ Natureza das situações } \\
\hline Apuração de Ato infracional de adolescente & 524 & 66.1 \\
\hline Adoção & 65 & 8.2 \\
\hline Precatória & 65 & 8.2 \\
\hline Guarda & 50 & 6.3 \\
\hline Abrigo & 35 & 4.4 \\
\hline Pedido de providências & 32 & 4.0 \\
\hline Tutela & 7 & 0.9 \\
\hline Entrega de filho & 5 & 0.6 \\
\hline Abandono & 2 & 0.3 \\
\hline Destituição de pátrio poder & 2 & 0.3 \\
\hline Autorização para trabalho & 2 & 0.3 \\
\hline Pedido de autorização para viagem & 1 & 0.1 \\
\hline Autorização para viagem para o exterior & 1 & 0.1 \\
\hline Infração administrativa & 1 & 0.1 \\
\hline Proced. Verificatório & 1 & 0.1 \\
\hline Total & 793 & 100.0 \\
\hline \multicolumn{3}{|l|}{ Mês de registro no ano } \\
\hline fevereiro & 75 & 9.5 \\
\hline Abril & 73 & 9.2 \\
\hline Setembro & 71 & 9.0 \\
\hline Julho & 70 & 8.8 \\
\hline Dezembro & 70 & 8.8 \\
\hline Junho & 68 & 8.6 \\
\hline Outubro & 67 & 8.4 \\
\hline Março & 66 & 8.3 \\
\hline Novembro & 64 & 8.1 \\
\hline janeiro & 59 & 7.4 \\
\hline Agosto & 56 & 7.1 \\
\hline maio & 54 & 6.8 \\
\hline Total & 793 & 100.0 \\
\hline
\end{tabular}

"Excluído l caso, para o qual isto não se aplica: "infração administrativa". **(38 processos de 3,8 de 4 e 6 de 5 ) 


\section{Anexo 20}

Tabela 16. Casos atendidos pelo Fórum de São Carlos, em 1991, registrados no Cartório da Infância e da Juventude de São Carlos, distribuidos segundo as características identificadas: sexo e idade.

\begin{tabular}{lcc}
\hline CARACTERISTICAS & No. & $\%$ \\
\hline Sexo & 779 & 76.3 \\
Masculino & 238 & 23.3 \\
Feminino & $4^{* *}$ & 0.4 \\
Sem informação & $1021^{*}$ & 100.0 \\
Total & & \\
Idade & 45 & 4.4 \\
$<1$ & 22 & 2.2 \\
01 & 13 & 1.3 \\
02 & 16 & 1.6 \\
03 & 15 & 1.5 \\
04 & 11 & 1.1 \\
05 & 15 & 1.5 \\
06 & 12 & 1.2 \\
07 & 12 & 1.2 \\
08 & 22 & 2.2 \\
09 & 35 & 3.4 \\
10 & 43 & 4.2 \\
11 & $(261)$ & $(25.6)$ \\
(<1 a 11 anos ) & 54 & 5.3 \\
12 & 54 & 5.3 \\
13 & 86 & 8.4 \\
14 & 109 & 10.7 \\
15 & 165 & 16.2 \\
16 & 201 & 19.7 \\
17 & $(669)$ & $(65.5)$ \\
(12 a 17 anos) & 2 & 0.2 \\
18 e + & $89^{* * *}$ & 8.7 \\
Sem informação & $1021^{*}$ & 100.0 \\
\hline Total & (t) & \\
\hline
\end{tabular}

*Excluído 1 caso, para o qual isto não se aplica.

**(3 nc, $1 \mathrm{ni}$ )

$* * *(67 \mathrm{nc}, 22 \mathrm{ni})$ 


\section{Anexo 21}

Tabela 17. Processos/situações atendidas pelo Fórum de São Carlos, em 1992, registradas no Cartório da Infância e da Juventude de São Carlos, distribuídas segundo as características identificadas: número de casos atendidos por situação, todas as naturezas encontradas e mês de registro da situação, no ano.

\begin{tabular}{lcr}
\hline CARACTERÍSTICAS & No. & $\%$ \\
\hline No. de Casos atendidos por situação & & \\
1 criança/adolescente & 733 & 76.8 \\
2 crianças/adolescentes & 148 & 15.5 \\
3 e + crianças/adolescentes (até 12) & $73^{* *}$ & 7.7 \\
Total & $954^{*}$ & 100.0 \\
Natureza das situações & & \\
Apuração de Ato infracional de & 639 & 66.1 \\
adolescente & & \\
Precatória & 93 & 9.6 \\
Pedido de providências & 77 & 8.0 \\
Guarda & 62 & 6.4 \\
Adoção & 39 & 4.0 \\
Abrigo & 29 & 3.0 \\
Infração Administrativa & 12 & 1.2 \\
Tutela & 6 & 0.6 \\
Pedido de Internamento & 4 & 0.4 \\
Entrega de filho & 2 & 0.2 \\
Destituição de pátrio poder & 1 & 0.1 \\
Pedido de Registro & 1 & 0.1 \\
Autorização para viagem para o exterior & 1 & 0.1 \\
Total & 966 & 100.0 \\
Mês de registro no ano & & \\
Maio & 104 & 10.8 \\
Abril & 101 & 10.5 \\
Março & 98 & 10.1 \\
Dezembro & 85 & 8.8 \\
Outubro & 78 & 8.1 \\
Janeiro & 77 & 8.0 \\
Fevereiro & 74 & 7.7 \\
Setembro & 73 & 7.6 \\
Julho & 72 & 7.5 \\
Junho & 70 & 7.2 \\
Noosto & 68 & 7.0 \\
\hline Total & 666 & 100.0 \\
\hline Exclubro & & \\
\hline
\end{tabular}

*Excluídos 12 casos, para os quais isto não se aplica.

**(39 processos de 3,19 de 4,7 de 5,3 de 6,2 de 7,2 de 8 e 1 de 12) 


\section{Anexo 22}

Tabela 18. Casos atendidos pelo Fórum de São Carlos, em 1992, registrados no Cartório da Infância e da Juventude de São Carlos, distribuídos segundo as características identificadas: sexo e idade.

\begin{tabular}{lcc}
\hline CARACTERISTICAS & No. & $\%$ \\
\hline Sexo & 1004 & 76.3 \\
Masculino & 302 & 22.9 \\
Feminino & 11 & 0.8 \\
Sem informação & $1317^{*}$ & 100.0 \\
Total & 19 & \\
Idade & 17 & 1.5 \\
$<1$ & 15 & 1.3 \\
01 & 13 & 1.1 \\
02 & 13 & 1.0 \\
03 & 19 & 1.0 \\
04 & 18 & 1.5 \\
05 & 22 & 1.4 \\
06 & 13 & 1.7 \\
07 & 25 & 1.0 \\
08 & 32 & 1.9 \\
09 & 47 & 2.4 \\
10 & $(253)$ & 3.6 \\
11 & 53 & $(19.2)$ \\
$(<1$ a 11 anos $)$ & 88 & 4.0 \\
12 & 140 & 6.7 \\
13 & 144 & 10.6 \\
14 & 210 & 10.9 \\
15 & 264 & 15.9 \\
16 & $(899)$ & 20.0 \\
17 & 6 & $(68.3)$ \\
(12 a 17 anos) & $159^{* *}$ & 0.5 \\
18 e + & $1317^{*}$ & 12.1 \\
Sem informação & 100.0 \\
\hline Total & & \\
\hline
\end{tabular}

* Excluídos retirados 12 casos em que não se aplica: iad.

**(134 nc; 23 ni, 2 nl) 


\section{Anexo 23}

Tabela 19. Processos/situações atendidas pelo Fórum de São Carlos, em 1993, registradas no Cartório da Infância e da Juventude de São Carlos, distribuídas segundo as características identificadas: número de casos atendidos por situação, todas as naturezas encontradas e mês de registro da situação, no ano.

\begin{tabular}{lcr}
\hline CARACTERÍSTICAS & No. & $\%$ \\
\hline No. de Casos atendidos por situação & & \\
1 criança/adolescente & 633 & 71.2 \\
2 crianças/adolescentes & 154 & 17.3 \\
3 e + crianças/adolescentes (até 11) & $102^{* *}$ & 11.5 \\
Total & $889^{*}$ & 100.0 \\
Natureza das situações & & \\
Apuração de Ato infracional de & 526 & 58.5 \\
adolescente & & \\
Precatória & 131 & 14.6 \\
Pedido de providências & 86 & 9.6 \\
Guarda & 72 & 8.0 \\
Adoção & 34 & 3.8 \\
Abrigo & 12 & 1.3 \\
Entrega de filho & 10 & 1.1 \\
Infração Administrativa & 8 & 0.9 \\
Autorização para estudo noturno & 6 & 0.7 \\
Abandono & 3 & 0.3 \\
Pedido autorização para trabalho & 3 & 0.3 \\
Averiguação & 3 & 0.3 \\
Tutela & 2 & 0.2 \\
Ação civil pública & 1 & 0.1 \\
Pedido de internamento & 1 & 0.1 \\
Apur. irregularidade entidade & 1 & 0.1 \\
atendimento & & \\
Total & 899 & 100.0 \\
Mês de registro no ano & & \\
Junho & 107 & 11.9 \\
Maio & 87 & 9.7 \\
Março & 85 & 9.5 \\
Novembro & 85 & 9.5 \\
Dezembro & 74 & 8.2 \\
Janeiro & 72 & 8.0 \\
Setembro & 72 & 7.9 \\
Agosto & 71 & 7.1 \\
Abril & 67 & 7.1 \\
Julho & 64 & \\
Outubro & 64 & \\
Fevereiro & 51 & \\
\hline Total & & \\
Excludos & & \\
\hline
\end{tabular}

*Excluídos 9 casos, em que isto não se aplica: 8 iad, laie e 1 acp.

**(61 processos de 3,19 de 4,11 de 5,5 de 6,4 de 7,1 de 8 e 1 de 11) 


\section{Anexo 24}

Tabela 20. Casos atendidos pelo Fórum de São Carlos, em 1993, registrados no Cartório da Infância e da Juventude de São Carlos, distribuídos segundo as caracteristicas identificadas: sexo e idade.

\begin{tabular}{|c|c|c|}
\hline CARACTERISTICAS & No. & $\%$ \\
\hline \multicolumn{3}{|l|}{ Sexo } \\
\hline Masculino & 991 & 74.4 \\
\hline Feminino & 328 & 24.6 \\
\hline Sem informação & $13^{* *}$ & 1.0 \\
\hline Total & $1332^{*}$ & 100.0 \\
\hline \multicolumn{3}{|l|}{ Idade } \\
\hline$<1$ & 38 & 2.8 \\
\hline 01 & 19 & 1.4 \\
\hline 02 & 15 & 1.1 \\
\hline 03 & 16 & 1.2 \\
\hline 04 & 9 & 0.7 \\
\hline 05 & 16 & 1.2 \\
\hline 06 & 11 & 0.8 \\
\hline 07 & 24 & 1.8 \\
\hline 08 & 20 & 1.5 \\
\hline 09 & 26 & 1.9 \\
\hline 10 & 44 & 3.3 \\
\hline 11 & 33 & 2.5 \\
\hline$(<1$ a 11 anos $)$ & (271) & $(20.3)$ \\
\hline 12 & 58 & 4.3 \\
\hline 13 & 79 & 5.9 \\
\hline 14 & 124 & 9.3 \\
\hline 15 & 168 & 12.6 \\
\hline 16 & 212 & 15.9 \\
\hline 17 & 194 & 14.6 \\
\hline (12 a 17 anos) & (835) & $(62.7)$ \\
\hline $18 e+$ & 40 & 3.0 \\
\hline sem informação & $186^{* * *}$ & 14.0 \\
\hline Total & $1332^{*}$ & 100.0 \\
\hline
\end{tabular}




\section{Anexo 25}

Tabela 21. Processos/situações atendidas pelo Fórum de São Carlos, em 1994, registradas no Cartório da Infância e da Juventude de São Carlos, distribuídas segundo as características identificadas: número de casos atendidos por situação, todas as naturezas encontradas e mês de registro da situação, no ano.

\begin{tabular}{|c|c|c|}
\hline CARACTERÍSTICAS & No. & $\%$ \\
\hline \multicolumn{3}{|l|}{ No. de Casos atendidos por situação } \\
\hline 1 criança/adolescente & 713 & 73.2 \\
\hline 2 crianças/adolescentes & 155 & 15.9 \\
\hline 3 e + crianças/adolescentes (até 7) & $106 * *$ & 10.9 \\
\hline Total & 974* & 100.0 \\
\hline \multicolumn{3}{|l|}{ Natureza das situações } \\
\hline $\begin{array}{l}\text { Apuração de Ato infracional de } \\
\text { adolescente }\end{array}$ & 538 & 54.5 \\
\hline Precatória & 115 & 11.6 \\
\hline Pedido de providências & 108 & 10.9 \\
\hline Guarda & 107 & 10.8 \\
\hline Adoção & 38 & 3.8 \\
\hline Abrigo & 27 & 2.7 \\
\hline Averiguação & 16 & 1.6 \\
\hline Infração administrativa & 10 & 1.0 \\
\hline Entrega de filho & 9 & 0.9 \\
\hline Tutela & 8 & 0.8 \\
\hline Proced. Verificatório & 7 & 0.7 \\
\hline $\begin{array}{l}\text { Apur. Irreg. Em entidade de } \\
\text { atendimento }\end{array}$ & 3 & 0.3 \\
\hline Pedido de registro & 1 & 0.1 \\
\hline Apreensão de menor & 1 & 0.1 \\
\hline Total & 988 & 100.0 \\
\hline \multicolumn{3}{|l|}{ Mês de registro no ano } \\
\hline Maio & 98 & 9.9 \\
\hline Agosto & 93 & 9.4 \\
\hline Julho & 91 & 9.2 \\
\hline Novembro & 89 & 9.0 \\
\hline Outubro & 87 & 8.8 \\
\hline Junho & 87 & 8.8 \\
\hline Abril & 84 & 8.5 \\
\hline Janeiro & 78 & 7.9 \\
\hline Março & 75 & 7.6 \\
\hline Dezembro & 75 & 7.6 \\
\hline Fevereiro & 71 & 7.2 \\
\hline Setembro & 60 & 6.1 \\
\hline Total & 988 & 100.0 \\
\hline
\end{tabular}




\section{Anexo 26}

Tabela 22. Casos atendidos pelo Fórum de São Carlos, em 1994, registrados no Cartório da Infância e da Juventude de São Carlos, distribuídos segundo as características identificadas: sexo e idade.

\begin{tabular}{lcc}
\hline CARACTERISTICAS & No. & $\%$ \\
\hline Sexo & 1051 & 73.1 \\
Masculino & 367 & 26.4 \\
Feminino & $7^{* *}$ & 0.5 \\
Sem informação & $1389^{*}$ & 100.0 \\
Total & & \\
Idade & 57 & 4.1 \\
$<1$ & 35 & 2.6 \\
01 & 26 & 1.8 \\
02 & 19 & 1.4 \\
03 & 18 & 1.3 \\
04 & 20 & 1.4 \\
05 & 20 & 1.4 \\
06 & 24 & 1.7 \\
07 & 17 & 1.2 \\
08 & 12 & 0.9 \\
09 & 28 & 2.0 \\
10 & 29 & 2.1 \\
11 & $(305)$ & $(22.0)$ \\
(<1 a 11 anos $)$ & 64 & 4.6 \\
12 & 80 & 5.7 \\
13 & 120 & 8.6 \\
14 & 158 & 11.4 \\
15 & 193 & 13.9 \\
16 & 196 & 14.1 \\
17 & $(811)$ & $(58.4)$ \\
$(12$ a 17 anos) & 100 & 7.2 \\
18 e + & $173^{* * *}$ & 12.4 \\
Sem informação & $1389^{*}$ & 100.0 \\
\hline Total & 9 & 17 \\
\hline
\end{tabular}

*Excluídos 14 casos em que não se aplica: 10 iad; 3aie e 1 ppr. (proc. $810 / 94)$

** (6 nc; $1 \mathrm{ni})$

*** (155 nc; $18 \mathrm{ni})$ 


\section{Anexo 27}

Tabela 23. Processos/situações atendidas pelo Fórum de São Carlos, em 1995, registradas no Cartório da Infância e da Juventude de São Carlos, distribuidas segundo as características identificadas: número de casos atendidos por situação, todas as naturezas encontradas e mês de registro da situação, no ano.

\begin{tabular}{lcc}
\hline CARACTERISTICAS & No. & $\%$ \\
\hline No. de Casos atendidos por situação & & \\
1 criança/adolescente & 761 & 76.5 \\
2 criaç̧as/adolescentes & 131 & 13.2 \\
3 e + crianças/adolescentes (até 21) & $102^{* *}$ & 10.3 \\
Total & $994^{*}$ & 100.0 \\
Natureza das situações & & \\
Apuração de Ato infracional de & 613 & 61.1 \\
adolescente & & \\
Precatória & 113 & 11.3 \\
Guarda & 76 & 7.6 \\
Pedido de providências & 63 & 6.3 \\
Adoção & 59 & 5.9 \\
Averiguação & 27 & 2.7 \\
Abrigo & 19 & 1.9 \\
Tutela & 9 & 0.9 \\
Infração administrativa & 7 & 0.7 \\
Destituição de pátrio poder & 5 & 0.5 \\
Entrega de filho & 5 & 0.5 \\
Ação civil pública & 2 & 0.2 \\
Pedido de autorização para trabalho & 2 & 0.2 \\
Pedido de curador especial & 1 & 0.1 \\
Pedido de internamento & 1 & 0.1 \\
Retificação de registro de nascimento & 1 & 0.1 \\
Total & 1003 & 100.0 \\
Mês de registro no ano & & \\
Julho & 110 & 11.0 \\
Maio & 101 & 10.1 \\
Março & 97 & 9.7 \\
Outubro & 91 & 9.1 \\
Novembro & 9.1 \\
Agosto & 91 & 9.0 \\
Abril & 90 & 8.7 \\
Junho & 87 & 7.9 \\
Setembro & 80 & 6.9 \\
Dezembro & 79 & 6.5 \\
Fevereiro & 69 & 4.3 \\
Janeiro & 65 & 100.0 \\
\hline Total & 43 & \\
\hline & 1003 & \\
Excludos & & \\
\hline
\end{tabular}

*Excluídos 9 casos, para os quais isto não se aplica: 7 iad e 2 acp.

** ( 56 casos de 3, 22 de 4, 9 de 5, 9 de 6,2 de 7,2 de 8,1 de 15 e 1 de 21 ) 


\section{Anexo 28}

Tabela 24. Casos atendidos pelo Fórum de São Carlos, em 1995, registrados no Cartório da Infầncia e da Juventude de São Carlos, distribuídos segundo as características identificadas: sexo e idade.

\begin{tabular}{|c|c|c|}
\hline CARACTERISTICAS & No. & $\%$ \\
\hline \multicolumn{3}{|l|}{ Sexo } \\
\hline Masculino & 1066 & 73.8 \\
\hline Feminino & 341 & 23.6 \\
\hline Sem informação & 37 & 2.6 \\
\hline Total & $1444^{*}$ & 100.0 \\
\hline \multicolumn{3}{|l|}{ Idade } \\
\hline$<1$ & 46 & 3.2 \\
\hline 01 & 28 & 1.9 \\
\hline 02 & 27 & 1.8 \\
\hline 03 & 15 & 1.0 \\
\hline 04 & 18 & 1.2 \\
\hline 05 & 11 & 0.8 \\
\hline 06 & 18 & 1.2 \\
\hline 07 & 16 & 1.1 \\
\hline 08 & 18 & 1.2 \\
\hline 09 & 21 & 1.5 \\
\hline 10 & 33 & 2.3 \\
\hline 11 & 44 & 3.0 \\
\hline$(<1$ a 11 anos $)$ & $(295)$ & (20.4) \\
\hline 12 & 57 & 3.9 \\
\hline 13 & 79 & 5.5 \\
\hline 14 & 158 & 10.9 \\
\hline 15 & 145 & 10.0 \\
\hline 16 & 182 & 12.6 \\
\hline 17 & 237 & 16.4 \\
\hline (12 a 17 anos) & (858) & (59.4) \\
\hline $18 \mathrm{e}+$ & 123 & 8.5 \\
\hline sem informação & $168^{* *}$ & 11.6 \\
\hline Total & $1444^{*}$ & 100.0 \\
\hline
\end{tabular}

*Excluídos 9 casos em que não se aplica: 7 iad; 2 acp.

** (137 nc; $31 \mathrm{ni})$ 


\section{Anexo 29}

Tabela 25. Processos/situações atendidas pelo Fórum de São Carlos, em 1996, registradas no Cartório da Infância e da Juventude de São Carlos, distribuídas segundo as características identificadas: número de casos atendidos por situação, todas as naturezas encontradas e mês de registro da situação, no ano.

\begin{tabular}{|c|c|c|}
\hline CARACTERISTICAS & No. & $\%$ \\
\hline \multicolumn{3}{|l|}{ No. de Casos atendidos por situacão } \\
\hline 1 criança/adolescente & 750 & 79.4 \\
\hline 2 crianças/adolescentes & 112 & 11.9 \\
\hline 3 e + crianças/adolescentes (até 28 ) & $82 * *$ & 8.7 \\
\hline Total & $944^{*}$ & 100.0 \\
\hline \multicolumn{3}{|l|}{ Natureza das situações } \\
\hline adolescente & 574 & 60.2 \\
\hline Pedido de providências & 113 & 11.9 \\
\hline Precatória & 108 & 11.3 \\
\hline Guarda & 59 & 6.2 \\
\hline Adoção & 56 & 5.9 \\
\hline Tutela & 10 & 1.0 \\
\hline Entrega de filho & 9 & 0.9 \\
\hline Averiguação & 7 & 0.7 \\
\hline Abrigo & 5 & 0.5 \\
\hline Infração administrativa & 5 & 0.5 \\
\hline Pedido de autorização para viagem & 2 & 0.2 \\
\hline Apreensão de menor & 2 & 0.2 \\
\hline Solicitação p/ retirada de FGTS & 1 & 0.1 \\
\hline Pedido de autorização para trabalho & 1 & 0.1 \\
\hline Destituição de pátrio poder & 1 & 0.1 \\
\hline Total & 953 & 100.0 \\
\hline \multicolumn{3}{|l|}{ Mês de registro no ano } \\
\hline Abril & 96 & 10.1 \\
\hline Março & 93 & 9.8 \\
\hline Agosto & 87 & 9.1 \\
\hline Junho & 82 & 8.6 \\
\hline Maio & 81 & 8.5 \\
\hline Setembro & 80 & 8.4 \\
\hline Novembro & 80 & 8.4 \\
\hline Outubro & 79 & 8.3 \\
\hline Julho & 78 & 8.2 \\
\hline Fevereiro & 75 & 7.9 \\
\hline Dezembro & 62 & 6.5 \\
\hline Janeiro & 60 & 6.3 \\
\hline Total & 953 & 100.0 \\
\hline
\end{tabular}

* Excluídos 9 casos, para os quais isto não se aplica: 5 iad e 4 ppr.

**(49 casos de 3, 22 de 4, 4 de 5, 2 de 6,2 de 7,1 de 8,1 de 24 e 1 de 28) 


\section{Anexo 30}

Tabela 26. Casos atendidos pelo Fórum de São Carlos, em 1996, registrados no Cartório da Infância e da Juventude de São Carlos, distribuídos segundo as características identificadas: sexo e idade.

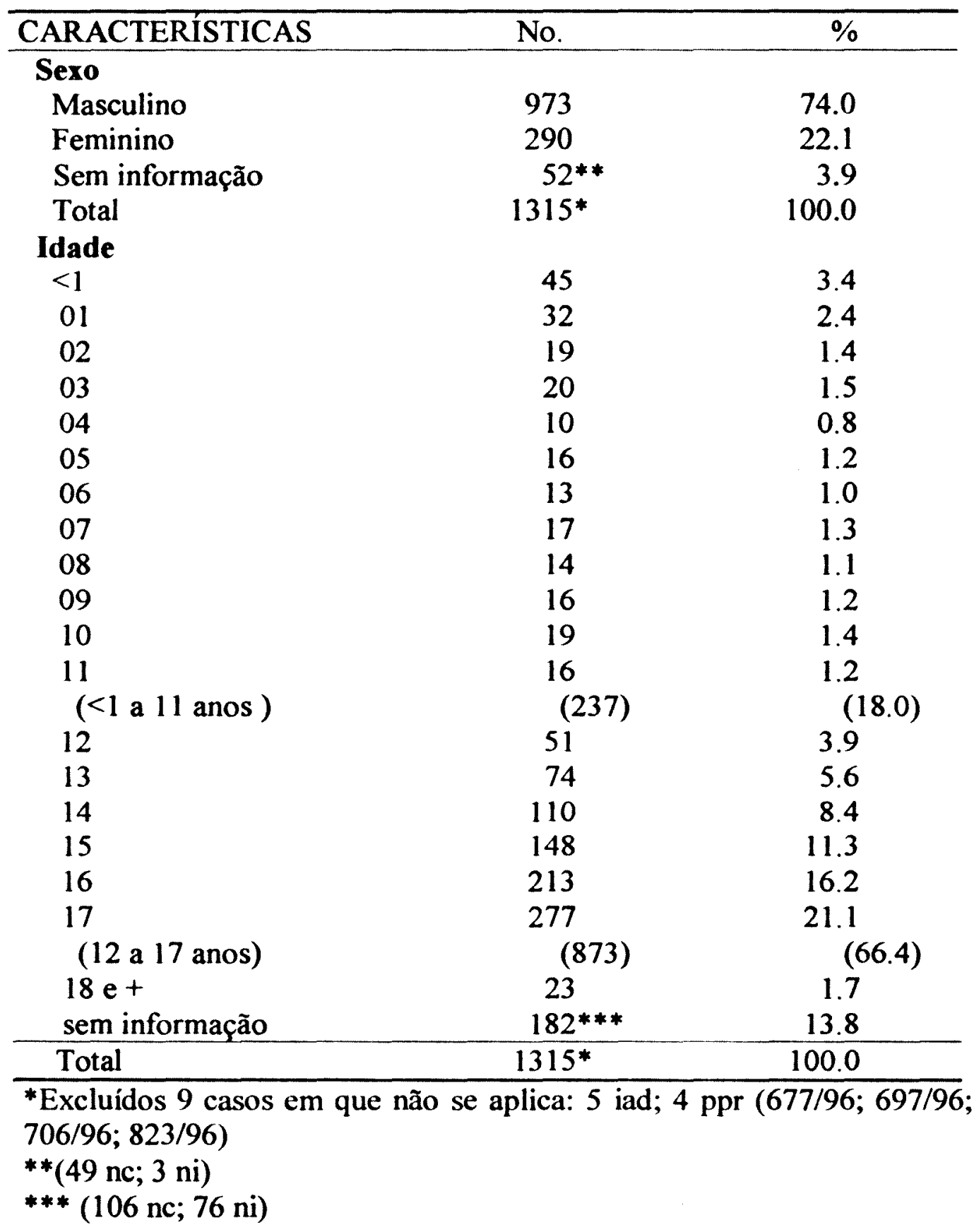


ANEXO 31-Tipos descritivos das situações infracionais e respectiva codificação. Tipos descritivos ditos infracionais

\section{Furto}

Agressão

Arma

Ameaça

Direção de veículo

Promovendo desordens

Sexualidade

\section{Roubo}

Homicídio

Danos

Alcool

Receptação

Desentendimentos

Rua

Direção de veículo com acidente

Droga

Estelionato

Fuga de casa

Foi remetido para outro Cartório ou Comarca

Não localizado

Ofensas

Outros mal definidos

Suicídio

Promovendo desordens / danos

Promovendo desordens / droga

Promovendo desordens / desacato

Desacato / arma

Agressão / arma

Agressão / danos

Agressão / lesão corporal c/ morte

Álcool / arma

Ameaça / agressão

Ameaça / promovendo desordens

Agressão / promovendo desordens

Ameaça / desacato

Ameaca / danos

Furto / agressão

Furto / estelionato

Furto / arma

Furto / droga

Furto / receptação

Furto / ameaça

Furto / danos

Direção de veículo $\mathrm{c} /$ acidente / homicídio

Não infracional / rua

Năo infracional / abandono

Não infracional / pai deu bebida ao filho

Não infracional /criança trancada em casa

Não infracional / fuga de casa (ou "de menor)

Não infracional / fugga de entidade

Não infracional / vitima de maus-tratos

Não infracional /mãe,pai queixa de conduta filho

Não infracional / tio pede poupança sobrinho

Não infracional / vítima de rapto

Sexualidade / agressão

Sexualidade / roubo

Droga / direção de veículo

Direção de veículo / ameaça

Direção de veículo / furto

Homicídio / agressão

Ofensas / agressão

Roubo / form. quadrilha

Fur

Codificação

EPI5

Agr

Arm

Ame

Dir

Pde

Sex

Rou

Hom

Dan

Alc

Rec

Des

Rua

Dirac

Dro

Est

Fca

Frem

Nlc

Ofe

Omd

Sui

pdetdan

pde+dro

pdetaca

acatarm

agrtarm

agr+dan

agr $+1 \mathrm{~cm}$

alctarm

ame+agr

ame+pde

agrtpde

ame+aca

ametdan

furtagr

furtest

furtarm

furtdro

furtrec

furtame

furtdan

Diracthom

pprtrua

pprtaba

ppr+bef

pprtctc

ppr+fca

pprtfen

ppr+mat

ppr+mfi

pprtpou

ppr+rpt

sextagr

sextrou

drotdir

dirtame

dirtfur

Hom+agr

ofe+agr

Routqua
Fu

Ag

Ar

Am

Di

Pd

Se

Ro

Hom

Dan

Alc

Rec

Des

Rua

Dirac

Dro

Est

Fca

Frem

NIc

Ofe

Omd

Sui

Pddan

Pddro

Pdaca

Acaar

Agar

Agdan

Aglem

Alcar

Amag

Ampd

Agpd

Amaca

Amdan

Fuag

Fuest

Fuar

Fudro

Furec

Fuam

Fudan

$\mathbf{Z}$

Irua

Iaba

Ibef

Icte

Ifca

Ifen

Imat

Imfi

Ipou

Irpt

Seag

Sero

Drodi

Diam

Difu

Homag

Ofeag

Roqua 
ANEXO 32

Quadro geral das medidas aplicadas, nas situações ditas infracionais e respectiva codificação. Tipos de medida

Remissão

Arquivamento

Advertência

Abrigo

Entrega e advertência à familia

Estudo social + entrega

Foi remetido para outro Cartório ou Comarca

Internação

Não consta a medida

Não localizado o processo

Apensamento

Termo de entrega e advertência

Advertência e estudo social

Advertência e orientação pelo Setor Técnico

Abrigo e Termo de entrega e advertência

Estudo social e remissão

Estudo social e arquivamento

Estudo social e entrega e advertência à familia

Estudo social e internação

Estudo social e advertência

Remissão e obrigação de matrícula e frequência em escola

Remissão e advertência

Representação e apensamento

Representação e busca e apreensão

Representação e internação

Representação e liberdade assistida

Representação e remissão

Representação e arquivamento

Representação e advertência

Representação e absolvição

Recambiamento e arquivamento

Remissão e liberdade assistida

Remissão e prestaç. serviç. comunid.

Estudo social, advertência e orientação pelo Setor Técnico

Estudo social, destituição de pátrio poder e abrigo

Estudo social e encaminhamento à programa

Estudo social, acompanhamento e advertência

Remisst̃o, reparação de danos e advertencia

Codificaça

rem

arq

adv

abr

eaf

een

frem

int

nc

nic

ape

tea

advtes

advtor

abrttea

estrem

estarq

esteaf

estint

estadv

rem+esc

rem+adv

reptape

rep+bap

reptint

reptla

rep+rem

reptarq

reptadv

reptabs

rectarq

rem+la

rem+psc

estadvtor

estdpptabr

est enc. prog

estactadv.

rem+ rd+adv

Remissão, orientação, apoio e acompanhamento pelo Setor Técnico e inclusão em programa de tratamento

Remissão, reparação de danos e prestação de serviços à comunidade

Remissão e orientação, apoio e acompanhamento pelo Setor Técnico

Remissåo, orientação, apoio e acompanhamento pelo Conselho Tutelar

Encaminhamento ao Conselho Tutelar

Representação, remissão e advertência

Rem+oaa/st+incl.prog.

trata/o

rem + rd + psc

rem + oaa/st

rem + oaa/ct

enc. ct

rep+rem+adv

Representação, remissão e acompanhamento pelo Setor técnico e obrigação de matrícula e rep+rem+ac/st+esc frequência em escola

Representação, advertência e liberdade assistida

Representação, liberdade assistida e prestação de serviços à comunidade

Representação, remissão e liberdade assistida

Representação, remissão e prestação de serviços à comunidade

Estudo social, abrigo, acompanhamento pelo Setor Técnico e internação

Abrigo, acompanhamento pelo Setor Técnico e arquivamento

rep+adv+la

rep+la+psc

reptrem+la

rep+rem+psc

estabr+ac/st+int

abr+ac/st+arq 


\section{ANEXO 33}

Quadro geral das medidas aplicadas pelo Juízo da Infância e da Juventude da Comarca de São Carlos, nas situações ditas infracionais, nos anos de 1986, 1991 e 1996 e respectivos números de casos, por tipo de medida e ano de aplicação.

Tipos de medida

Remissão

Arquivamento

Advertência

Abrigo

Entrega e advertencia à familia

Estudo social + entrega

Internação

Não consta a medida

Apensamento

Termo de entrega e advertencia

Advertência e estudo social

Advertencia e orientação pelo Setor Técnico

Abrigo e Termo de entrega e advertência

Estudo social e remissão

Estudo social e arquivamento

Estudo social e entrega e advertência à familia

Estudo social e internação

Estudo social e advertencia

Remissão e obrigaçâo de matricula e frequência em escola

Remissão e advertência

Representaçåo e apensamento

Representação e busca e apreensão

Representação e internação

Representação e liberdade assistida

Representaçăo e remissão

Representaçåo e arquivamento

Representação e advertência

Representação e absolvição

Recambiamento e arquivamento

Remissâo e liberdade assistida

Remissão e prestą̧̃o de serviços à comunidade

Estudo social, advertência e orientação pelo Setor Técnico

Estudo social, destituição de pátrio poder e abrigo

Estudo social e encaminhamento à programa

Estudo social, acompanhamento e advertência

Remissåo, reparação de danos e advertência

Remissão, orientação, apoio e acompanhamento pelo Setor Técnico e inclusẫo em programa de tratamento

Remissão, reparaçåo de danos e prestação de serviços à comunidade

Remissão e orientação, apoio e acompanhamento pelo Setor Técnico

Remissão, orientação, apoio e acompanhamento pelo Conselho Tutelar

Encaminhamento ao Conselho Tutelar

Representação, remissão e advertência

Representação, remissão, acompanhamento pelo Setor técnico e obrigação de matricula e frequencia em escola

Representação, advertência e liberdade assistida

Representação, liberdade assistida e prestação de serviços à comunidade

Representação, remissão e liberdade assistida

Representação, remissẫo e prestação de serviços à comunidade

Estudo social, abrigo, acompanhamento pelo Setor Técnico e internação

Abrigo, acompanhamento pelo Setor Técnico e arquivamento

Total

\begin{tabular}{|c|c|c|c|c|c|}
\hline 198 & & 19 & & & \\
\hline $\mathbf{N}$ & $\%$ & N. & $\%$ & N. & $\%$ \\
\hline 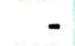 & & 240 & 353 & 331 & 42.0 \\
\hline 112 & 26.8 & 304 & 44.7 & 153 & 19.4 \\
\hline 251 & 60.2 & 01 & 0.1 & 01 & 0.1 \\
\hline 01 & 0.2 & - & - & - & - \\
\hline 01 & 0.2 & - & - & - & - \\
\hline 02 & 0.5 & - & - & - & m \\
\hline 02 & 0.5 & 02 & 0.3 & , & . \\
\hline 01 & 0.2 & - & $=$ & - & - \\
\hline & - & 09 & 1.3 & 03 & 0.4 \\
\hline & $=$ & 01 & 0.1 & - & - \\
\hline 10 & 2.4 & - & - & - & - \\
\hline 11 & 2.6 & - & - & - & - \\
\hline- & - & 07 & 1.0 & - & - \\
\hline - & - & 01 & 0.1 & - & - \\
\hline 13 & 3.1 & 03 & 0.4 & 01 & 0.1 \\
\hline 01 & 0.2 & - & - & - & - \\
\hline 05 & 1.2 & - & - & - & - \\
\hline 05 & 1.2 & - & - & - & - \\
\hline - & & 02 & 0.3 & - & $=$ \\
\hline - & - & 21 & 3.1 & 109 & 13.8 \\
\hline - & & 02 & 0.3 & - & - \\
\hline - & - & 01 & 0.1 & - & - \\
\hline - & & 03 & 0.4 & 08 & 1.0 \\
\hline - & - & 17 & 2.5 & 08 & 1.0 \\
\hline - & • & 03 & 0.4 & 67 & 8.5 \\
\hline - & - & 10 & 1.5 & 13 & 1.6 \\
\hline - & & 28 & 4.1 & 01 & 0.1 \\
\hline - & - & - & $=$ & 04 & a.5 \\
\hline - & - & 12 & 1.8 & - & - \\
\hline & & - & 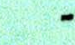 & 08 & 1.0 \\
\hline- & & - & - & $10-$ & 1.3 \\
\hline 01 & 0.2 & - & - & - & - \\
\hline 01 & 0.2 & - & - & - & - \\
\hline 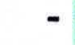 & & 02 & 0.3 & - & - \\
\hline - & • & 01 & 0.1 & - & . \\
\hline - & & 01 & 0.1 & - & - \\
\hline - & - & 03 & 0.4 & - & - \\
\hline - & & - & & 02 & 0.3 \\
\hline- & & - & - & 01 & 0.1 \\
\hline - & - & - & - & 02 & 0.3 \\
\hline & & - & - & 03 & 0.4 \\
\hline - & 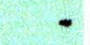 & 01 & 0.1 & 09 & 1.1 \\
\hline & - & 02 & 0.3 & - & - \\
\hline & & 01 & e.1 & - & - \\
\hline & & - & + & 03 & 0.4 \\
\hline & & & & 22 & 2.8 \\
\hline & & & 7 & 29 & 3.7 \\
\hline " & 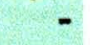 & 01 & 0.1 & - & - \\
\hline & & 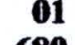 & 0.1 & & \\
\hline 417 & 100.0 & 680 & 100.0 & 788 & 0.0 \\
\hline
\end{tabular}

Excluídos os processos não localizados ( 5 casos em 1986, 4 casos em 1991 e 1 caso em 1996) e os que foram remetidos a outro Cartório ou Comarca (1 caso em 1986, 3 casos em 1991 e 7 casos em 1996). 